$$
\text { UNIVERSIDADE DE SÃO PAULO }
$$

FACULDADE DE FILOSOFIA, LETRAS E CIÊNCIAS HUMANAS DEPARTAMENTO DE CIÊNCIA POLÍTICA PROGRAMA DE PÓS-GRADUAÇÃO EM CIÊNCIA POLÍTICA

\author{
Felipe Freller
}

\title{
Benjamin Constant e o problema do arbítrio: um decisionismo moderado
}

São Paulo

2020 


\title{
FELIPE FRELLER
}

\section{Benjamin Constant e o problema do arbítrio:}

\author{
um decisionismo moderado
}

\section{Versão Original}

Tese de doutorado apresentada ao Programa de Pós-Graduação em Ciência Política da Faculdade de Filosofia, Letras e Ciências Humanas da Universidade de São Paulo, em dupla titulação com a École des Hautes Études en Sciences Sociales, como parte dos requisitos para a obtenção do título de Doutor em Ciência Política.

Orientadora: Profa. Dra. Eunice Ostrensky Coorientador: Prof. Dr. Frédéric Brahami

São Paulo 
Autorizo a reprodução e divulgação total ou parcial deste trabalho, por qualquer meio convencional ou eletrônico, para fins de estudo e pesquisa, desde que citada a fonte.

Catalogação na Publicação

Serviço de Biblioteca e Documentação

Faculdade de Filosofia, Letras e Ciências Humanas da Universidade de São Paulo

F $868 \mathrm{~b}$

Freller, Felipe

Benjamin Constant e o problema do arbítrio: um decisionismo moderado / Felipe Freller ; orientadora Eunice Ostrensky. - São Paulo, 2020.

$298 \mathrm{f}$.

Tese (Doutorado) - Faculdade de Filosofia, Letras e Ciências Humanas da Universidade de São Paulo. Departamento de Ciência Política. Área de concentração: Ciência Política.

1. Benjamin Constant. 2. Arbítrio. 3. Decisão política. 4. Liberalismo. I. Ostrensky, Eunice, orient. II. Título. 


\title{
Nome: FRELLER, Felipe
}

Título: Benjamin Constant e o problema do arbítrio: um decisionismo moderado

Tese de doutorado apresentada ao Programa de Pós-Graduação em Ciência Política da Faculdade de Filosofia, Letras e Ciências Humanas da Universidade de São Paulo, em dupla titulação com a École des Hautes Études en Sciences Sociales, como parte dos requisitos para a obtenção do título de Doutor em Ciência Política.

Aprovado em:

\author{
Banca Examinadora
}

Prof. Dr.

Instituição:

Julgamento:

Assinatura:

Prof. Dr.

Instituição:

Julgamento:

Assinatura:

Prof. Dr.

Instituição:

Julgamento:

Assinatura:

Prof. Dr. Instituição:

Julgamento: Assinatura:

Prof. Dr. Instituição:

Julgamento: Assinatura: 
Para meus pais, Daniel e Cintia, minha avó, Melany (in memorian), e minha companheira, Maíra. 


\section{Agradecimentos}

Elaborada durante um período turbulento, crítico e difícil da história do Brasil e do mundo, esta tese aposta que o estudo de autores do passado que também viveram momentos de grandes crises e transformações pode nos fornecer referências intelectuais que ainda são capazes de nos situar e nos orientar de alguma forma. Reafirmar a importância desse tipo de estudo se torna a cada dia mais fundamental, dada a crescente desvalorização do trabalho acadêmico por parte de discursos políticos que adquiriram proeminência em nossa sociedade e a inclinação demasiadamente presentista e utilitarista de uma porção hegemônica da própria comunidade acadêmica. Em certo sentido, a presente tese procura fazer da própria situação de crise um estímulo para a formulação de perguntas teóricas. Notadamente, o tema da decisão, que procuramos mostrar ser central na obra de Benjamin Constant, aflora inevitavelmente em momentos de crise como a que o Brasil vive há alguns anos, em que se tornam recorrentes os questionamentos sobre quem tem o direito de decidir sobre as resoluções das crises e sob que condições. Para empreender a pesquisa que resultou nesta tese em um período marcado por tantas perplexidades, pude, felizmente, contar com preciosos apoios.

Agradeço profundamente aos dois orientadores desta tese, a Profa. Eunice Ostrensky, da USP, e o Prof. Frédéric Brahami, da EHESS, sem os quais este trabalho não seria o mesmo. À Profa. Eunice, agradeço especialmente o acolhimento recebido há dez anos, quando comecei uma Iniciação Científica sob sua orientação sobre Alexis de Tocqueville, assim como a atenção e o rigor com que meus textos foram lidos, as sugestões valiosas e os incentivos recebidos ao longo desses dez anos de Iniciação Científica, Mestrado e Doutorado. Certamente será estranho, após dez anos, iniciar um novo caminho sem essa orientação, mas espero me apoiar na preciosa experiência adquirida ao longo dessa parceria. Ao Prof. Frédéric, agradeço a disposição de me receber para um estágio de pesquisa na França, em 2014, e seu pronto aceite de ser meu coorientador no doutorado, permitindo que eu me beneficiasse de seus ensinamentos e conselhos, assim como do ambiente acadêmico de Paris e da EHESS.

Agradeço aos professores Cícero Romão Resende de Araújo e Christian Edward Cyril Lynch por sua participação no exame de qualificação ocorrido na USP, em dezembro de 2017 - um evento que se tornou fundamental para a reformulação do objeto 
de pesquisa, tornando-o mais preciso e original, razão pela qual agradeço inclusive os comentários mais duros feitos naquela ocasião. Agradeço igualmente aos professores Pierre Manent, Vincent Duclert e Patrice Gueniffey, por sua generosa participação nos “comités de suivi de thèse" realizados na EHESS, em junho de 2018 e junho de 2019. Os comentários e sugestões desses três renomados professores da EHESS, nessas duas ocasiões, foram valiosos e, na medida do possível, incorporados na tese, tornando-a mais rica.

Agradeço a Eunice Ostrensky, Cícero Romão Resende de Araújo, Bernardo Ricupero, Paulo Henrique Paschoeto Cassimiro, Roberta K. Soromenho Nicolete, Célia Galvão Quirino, Newton Bignotto, Luís Falcão, Marcelo Gantus Jasmin, Christian Edward Cyril Lynch, Diego Ambrosini e Ivo Coser pela organização e participação no Evento 200 anos de "Da liberdade dos antigos comparada à dos modernos", de Benjamin Constant: Que liberdade para os tempos modernos?, ocorrido em novembro de 2019, na USP, no qual tivemos a oportunidade de discutir o legado e as interpretações contemporâneas de Benjamin Constant, objeto desta tese, a qual se beneficiou muito das discussões desse evento.

Agradeço aos secretários do Departamento de Ciência Política da USP, Márcia Regina G. Staaks, Vasne dos Santos, Leonardo de Novaes e Aureluce Pimenta, pela dedicação e ajuda aos pós-graduandos em tempos difíceis. Agradeço também aos funcionários da Bibliothèque nationale de France $(\mathrm{BnF})$, da Bibliothèque SainteGeneviève (BSG), da Bibliothèque de la Fondation Maison des sciences de l'homme (FMSH) e da Biblioteca Florestan Fernandes, da FFLCH, onde uma parte fundamental da pesquisa que resultou nesta tese de doutorado foi realizada.

Agradeço a todos aqueles que discutiram o assunto desta tese comigo, seja em contextos formais ou informais. Sou grato aos encontros do Grupo de Estudos de Teoria Política Moderna, centrado em torno da Profa. Eunice Ostrensky e composto atualmente por Amanda Rigo Pradella, Ananda Chaves Fonseca, Ana Beatriz Martins Craveiro, Gabriela Rosa e Sérgio Mendonça, mas que já incluiu Patrício Tierno, Roberta K. Soromenho Nicolete, Breno Barlach, Caio Izaú e Christiane Cardoso Ferreira, entre outros que contribuíram enormemente para minha formação em Teoria Política ao longo dos últimos dez anos. Agradeço também às conversas com Ronaldo Tadeu de Souza, Maria Cecília Ipar, Lilian Sendretti e Felipe Linden, além de outros amigos que, mesmo em contextos informais e despretensiosos, me ajudaram a elaborar ideias para esta tese. 
Agradeço imensamente a Clara Gensburger e Clément Morier, queridos amigos franceses que se dispuseram a revisar uma parte importante da versão francesa da tese gratuitamente, pela simples curiosidade de conhecer minha pesquisa. Agradeço também a Anne Marsaleix e Bruna Carvalho, que revisaram e ajudaram a aprimorar outras partes da versão da tese em francês.

Agradeço aos amigos André Bueno Rezende de Castro, Gabriel Salvi Philipson, Marcel de Carvalho Enderle, Pedro Bacchi, Ricardo Zimmerman, Thomás Zicman de Barros e Vitor Ortiz Amando de Barros, sempre próximos, pelos momentos de fruição e descontração, sem os quais o estudo seria impossível, e a vida, penosa.

Agradeço profundamente a meus pais, Daniel Freller e Cintia Copit Freller, pelo amor incondicional e pelo apoio constante. Ao meu irmão, Marcelo Freller, pelo companheirismo. À minha querida avó, Melany Schvartz (in memorian), que nos deixou este ano, por ter instigado em mim a paixão pelas leituras e pelas ciências humanas, mas por ter insistido também na importância de outros desenvolvimentos para além do intelectual.

Agradeço, do fundo do meu coração, à minha amada companheira, Maíra Gerstner, por ter tornado minha vida mais feliz e completa, e por me dar ânimo para seguir em frente com confiança.

Agradeço à FAPESP, Fundação de Amparo à Pesquisa do Estado de São Paulo, pelo apoio financeiro que tornou esta pesquisa possível, por meio dos processos 2015/21607-6 e 2017/03986-5, Fundação de Amparo à Pesquisa do Estado de São Paulo (FAPESP). 
"Os homens, hoje em dia, não fazem nada por si mesmos. Para as ações intimas, há dogmas religiosos positivos. Para as ações exteriores, há a lei. Assim, quando a lei ou a religião se esfacela, os homens não têm mais guia e não sabem mais o que devem fazer". 


\section{Resumo}

Esta tese se debruça sobre o "problema do arbítrio" na obra de Benjamin Constant. Embora o autor franco-suíço tenha sido um crítico ferrenho de governos arbitrários, procuramos tratar o arbítrio como um verdadeiro problema político enfrentado pelo escritor, não como um simples mal rejeitado por ele em um plano normativo. Argumentamos, assim, que Constant não expulsa definitivamente a decisão arbitrária do campo da política legítima, como querem alguns de seus intérpretes, mas procura antes incorporar o arbítrio ao sistema político de maneira controlada, de modo a evitar sua deriva tirânica - uma atitude para a qual propomos a designação de "decisionismo moderado". A tese concede primazia metodológica à interação dinâmica do autor com a realidade política de seu tempo, considerando essa interação como a instância que produz os problemas a serem elaborados no plano teórico. Assim, no Capítulo 1, procuramos compreender de que modo o problema do arbítrio emerge no pensamento do jovem Constant sob o Primeiro Diretório (1795-1797), em um diálogo crítico com autores que propomos interpretar pela categoria de "liberalismo da ordem" - notadamente PierreLouis Roederer e Adrien de Lezay-Marnésia. Embora a primeira resposta de Constant ao problema do arbítrio tenha sido sua rejeição incondicional, argumentamos, no Capítulo 2, que essa rejeição é reavaliada após o golpe de Estado do 18 Frutidor do Ano V, e que essa reavaliação culmina na formulação da ideia do poder neutro como uma "autoridade discricionária”. No Capítulo 3, examinamos a nova configuração do problema do arbítrio proporcionada pela "virada liberal" dos Princípios de política de 1806, procurando mostrar que, por um lado, o arbítrio é condenado sobre novas bases, mas que, por outro lado, a decisão arbitrária passa a ser disseminada no interior do edifício constitucional, na forma de múltiplas instâncias em que a lei pode ser contornada ou contrariada, a fim de evitar a tirania da lei excessiva. Por fim, o Capítulo 4 trata do lugar do arbítrio na monarquia constitucional teorizada por Constant a partir de 1814, analisando as novas nuances da versão monárquica do poder neutro e a interpretação da responsabilidade dos ministros como um julgamento inevitavelmente arbitrário. A Conclusão ressalta Constant como um eminente teórico da decisão e do arbítrio, buscando discernir em sua obra um paradigma da decisão alternativo em relação aos já estabelecidos na teoria política.

Palavras-chave: Benjamin Constant; Arbítrio; Decisão política; Liberalismo 


\section{Abstract}

This thesis aims to study the "arbitrariness issue" in the work of Benjamin Constant. Although the author has been a relentless critic of arbitrary governments, we seek to treat arbitrariness as a real political issue faced by him, not as a simple harm rejected by him on a normative level. We argue that Constant does not cast out definitively arbitrary decision from the field of legitimate politics, as some of his interpreters suggest. He rather seeks to incorporate arbitrariness into the political system in a controlled manner, in order to avoid its tyrannical drift - an attitude for which we propose the designation of "moderate decisionism". The thesis accords methodological primacy to the dynamic interaction between the author and the political reality of his time, considering this interaction as the source of the issues to be elaborated on the theoretical level. Thus, in Chapter 1, we seek to understand how the arbitrariness issue arises in Constant's thought under the First Directory (1795-1797), in a critical dialogue with authors we propose to interpret through the category of "liberalism of order" - notably Pierre-Louis Roederer and Adrien de Lezay-Marnésia. Although Constant's first response to the arbitrariness issue was its unconditional rejection, we argue, in Chapter 2, that this rejection is reassessed after the Coup of 18 Fructidor, Year V, and that this reassessment culminates in the formulation of the idea of neutral power as a "discretionary authority". In Chapter 3 , we examine the new configuration of the arbitrariness issue provided by the "liberal turn" of the 1806 Principles of politics, seeking to demonstrate that, on the one hand, arbitrary is condemned on a new basis, but that, on the other hand, arbitrary decision is disseminated within the constitutional edifice, in the form of multiple cases in which the law can be circumvented or broken, in order to avoid the tyranny of excessive law. Finally, Chapter 4 focuses on the place of arbitrariness in the constitutional monarchy theorized by Constant from 1814 onwards, analyzing the new nuances of the monarchical version of neutral power and the responsibility of ministers interpretation as an inevitably arbitrary judgement. The Conclusion highlights Constant as an eminent theorist in the domains of discretion and arbitrariness, seeking to discern in his work an alternative paradigm of the concept of political decision in relation to those already established in political theory.

Keywords: Benjamin Constant; Arbitrariness; Political decision; Liberalism 


\section{Résumé}

Cette thèse a pour objet le « problème de l'arbitraire » chez Benjamin Constant. Bien que l'auteur critique impitoyablement les gouvernements arbitraires, nous cherchons à aborder l'arbitraire comme un véritable problème politique auquel il a dû faire face, et non pas comme un simple mal qu'il rejette selon une morale normative. Nous soutenons que Constant n'écarte pas définitivement la décision arbitraire du domaine de la politique légitime, mais qu'il cherche plutôt à incorporer l'arbitraire au système politique d'une manière contrôlée, afin d'éviter sa dérive tyrannique - une attitude pour laquelle nous proposons la désignation de «décisionnisme modéré ». Nous attribuons la primauté méthodologique à l'interaction dynamique de l'auteur avec la réalité politique de son temps, considérant cette interaction comme productrice des problèmes qu'il cherche à élaborer au niveau théorique. Ainsi, au Chapitre 1, nous tâchons de comprendre comment le problème de l'arbitraire émerge dans la pensée de Constant sous le Premier Directoire (1795-1797), dans un dialogue critique avec des auteurs que nous proposons d'interpréter selon la catégorie du « libéralisme de l'ordre »- notamment Pierre-Louis Roederer et Adrien de Lezay-Marnésia. Bien que la première réponse de Constant au problème de l'arbitraire soit son rejet inconditionnel, nous avançons, au Chapitre 2, que ce rejet subit une réévaluation après le coup d'État du 18 fructidor an $\mathrm{V}$, aboutissant à la formulation de l'idée du pouvoir neutre comme une « autorité discrétionnaire ». Au Chapitre 3, nous examinons la nouvelle configuration du problème de l'arbitraire qu'engendre le « tournant libéral » des Principes de politique de 1806, en cherchant à montrer qu'en même temps que l'arbitraire y est condamné sur de nouvelles bases, la décision arbitraire y est désormais disséminée à l'intérieur de l'édifice constitutionnel, sous la forme de domaines divers dans lesquels la loi peut être contournée voire transgressée, afin d'éviter la tyrannie de la loi excessive. Au Chapitre 4, nous abordons la place de l'arbitraire dans la monarchie constitutionnelle théorisée par Constant à partir de 1814, en analysant les nouvelles nuances de la version monarchique du pouvoir neutre et l'interprétation de la responsabilité des ministres comme un jugement inéluctablement arbitraire. La conclusion vise à discerner dans l'œuvre de Constant un paradigme de la décision alternatif à ceux déjà établis dans la théorie politique.

Mots clés : Benjamin Constant ; Arbitraire ; Décision politique ; Libéralisme 


\section{Sumário}

Introdução. .14

Capítulo 1 - A Revolução Francesa já terminou? Benjamin Constant e o liberalismo da ordem. .38

1.1. O problema do arbítrio, de Locke à Revolução Francesa 41

1.2. O liberalismo da ordem e a obliteração do problema do arbítrio. .56

1.3. Benjamin Constant e o problema do arbítrio em um contex to de reação política.......72

1.4. Uma controvérsia sobre o Terror. .91

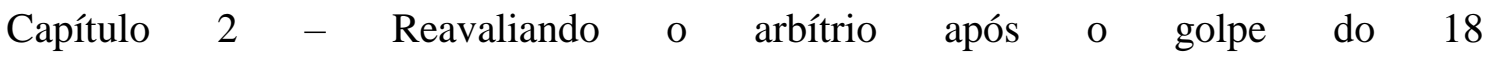
Frutidor. . .99

2.1. Uma defesa contraditória do golpe. 106

2.2. Do revisionismo constitucional à Constituição do Ano VIII e a sua crítica por Necker: as reações ao 18 Frutidor no entourage de Constant.

2.3. Uma autoridade discricionária.

Capítulo 3 - Império da lei e insuficiência da lei nos Principes de politique de 1806. 156

3.1. A nova filosofia política liberal: limitação da soberania e crítica do excesso de leis. 160

3.2. Medidas de polícia e golpes de Estado. 169

3.3. A incorporação do arbítrio na ordem judiciária: júri e direito de graça. 176

3.4. Desobediência civil e sentimento religioso: o arbítrio ao alcance de cada indivíduo 
Capítulo 4: A disseminação do arbítrio na monarquia constitucional.

4.1. A versão monárquica do poder neutro e a imersão de Constant na tradição monarquista. .218

4.2. Responsabilidade dos ministros, um julgamento inevitavelmente arbitrário. 236

4.3. Constant perante o confronto entre interpretações parlamentaristas e antiparlamentaristas da Carta de 1814 254

Conclusão. .269

Bibliografia .282 


\section{Introdução}

"Defendi durante quarenta anos o mesmo princípio, liberdade em tudo, em religião, em filosofia, em literatura, em indústria, em política"1 (CONSTANT, 1997, p. 623). Com essa conhecida fórmula enunciada no fim de sua vida, no Prefácio dos Mélanges de littérature et de politique, de 1829, Benjamin Constant de Rebecque (17671830) buscava ressaltar a coerência de uma trajetória intelectual e política que havia chocado muitos de seus contemporâneos por uma série de mudanças bruscas de posição, as quais renderam ao autor o apelido de "l'inconstant Benjamin". Essas mudanças bruscas de posição remontam ao início de sua carreira política na França, em 1795, quando, recém-chegado a Paris, ele combate a intenção da Convenção termidoriana de perpetuar seus membros no poder por meio dos "decretos dos dois terços", passando a colaborar para a efetivação desses decretos poucos meses depois. Em 1797, o jovem orador apoia o golpe do Diretório contra os monarquistas que haviam sido eleitos para os Conselhos (golpe de Estado do 18 Frutidor), arrependendo-se desse apoio em vários de seus escritos posteriores, nos quais os golpes de Estado são condenados de modo incondicional. Durante o período do Diretório (1795-1799) e do Consulado (1799-1804), Constant defende o regime republicano e se opõe vigorosamente à possibilidade de uma restauração da monarquia, acusada de trazer inevitavelmente consigo a tirania e os furores da contrarrevolução. Em 1814, ele apoia a restauração da monarquia Bourbon, passando a defender a monarquia constitucional como superior à República. Em 1815, o autor apoia Napoleão Bonaparte e colabora para a redação do Ato Adicional às Constituições do Império, a Constituição do Governo dos Cem Dias, após haver chamado Bonaparte de tirano e usurpador e haver conclamado o povo francês a resistir a seu retorno.

Constant sempre alegou ter se mantido fiel aos mesmos princípios liberais em todas essas mudanças de posição, buscando apenas acomodar os princípios a circunstâncias políticas cambiantes. Essa alegação tem sido confirmada pelos mais importantes intérpretes do autor nas últimas décadas, como Marcel Gauchet, Stephen Holmes, Kurt Kloocke, Biancamaria Fontana, Tzvetan Todorov, Lucien Jaume e Helena

${ }^{1}$ Todas as citações desta tese cuja referência bibliográfica se encontra em outra língua que não o português foram traduzidas por mim. 
Rosenblatt. $^{2}$ A publicação, nas duas últimas décadas do século XX, dos dois principais tratados políticos de Constant, os Fragments d'un ouvrage abandonné sur la possibilité d'une constitution républicaine dans un grand pays (publicado em 1991) e os Principes de politique de 1806 (publicado em 1980), que o autor não havia publicado em vida, mas dos quais havia extraído o material para uma série de publicações mais circunstanciais, contribuiu para assentar a unidade, a coerência e a constância de seu pensamento. O leitor atual pode verificar que muito do que Constant publicou em sua última década de vida já se encontrava formulado de modo sistemático nos anos 1800-1810, por vezes antes.

Entre os princípios defendidos por Constant ao longo de toda a sua vida, merece destaque a condenação implacável do arbítrio (l'arbitraire) em política. Já presente em sua primeira brochura política, De la force du gouvernement actuel de la France et de la nécessité de s'y rallier, de 1796, a condenação do arbítrio se prolonga em praticamente todas as suas obras políticas, servindo para criticar diversos alvos, da monarquia do Antigo Regime à política do partido ultra sob a Restauração, passando pelo Terror jacobino e pelo Império napoleônico. ${ }^{3}$ Ao longo de sua vasta obra, o autor sistematizou argumentos e empregou todo o seu talento retórico para condenar qualquer governo que se colocasse acima das leis e dos princípios de moderação, estendendo essa condenação a medidas isoladas que permitissem mesmo a governos não absolutos escapar por um

2 Afirmações sobre a unidade, coerência e constância do pensamento de Constant podem ser encontradas em: GAUCHET, 1997, p. 17; GAUCHET, 2005, p. 278; HOLMES, 1984, p. 4; KLOOCKE, 1984, p. 5-6; FONTANA, 1991, p. xvii; TODOROV, 1997, p. 23-24.

${ }^{3}$ Exemplos notáveis da crítica de Constant ao arbítrio podem ser encontrados no Capítulo 8 de $D e$ la force du gouvernement (CONSTANT, 1988, p. 83-88), no Capítulo 9 de Des réactions politiques (CONSTANT, 1964, p. 72-82), no ensaio Des effets de la Terreur (CONSTANT, 1964, p. 95-112), em seus discursos no Tribunato (CONSTANT, 2005a, p. 78-79; CONSTANT, 2005a, p. 215-244), nos Livros V e VI dos Principes de politique de 1806 (CONSTANT, 1980, p. 93-123), nos Capítulos 10 a 17 da Segunda Parte de De l'esprit de conquête et de l'usurpation (CONSTANT, 1997, p. 225-263), no Capítulo 14 de De la responsabilité des ministres (CONSTANT, 1982, p. 431-442) e no Capítulo 18 dos Principes de politique de 1815 (CONSTANT, 1997, p. 483-491). Vale lembrar que, em seu texto hoje mais conhecido, "Da liberdade dos antigos comparada à dos modernos”, de 1819, o primeiro aspecto da liberdade dos modernos a ser destacado pelo autor é "para cada um o direito de não se submeter senão às leis, de não poder ser preso, nem detido, nem condenado, nem maltratado de nenhuma maneira, pelo efeito da vontade arbitrária de um ou de vários indivíduos" (CONSTANT, 1985, p. 1; ênfase nossa). 
momento do círculo de ação traçado pela Constituição, sob a alegação, por exemplo, de uma situação de urgência ou perigo para o corpo político.

Alguns comentadores ressaltam a originalidade de Constant - e também de Madame de Staël, sua companheira que o influenciou muito nessa direção - nessa condenação tão categórica e absoluta do arbítrio. Como nota Alain Laquièze (2003, p. 4041), a questão da existência de situações de urgência em que os governantes podem se liberar das regras normais de funcionamento do Estado, agindo de modo "arbitrário", é clássica desde pelo menos o século XII, a resposta da filosofia política a essa questão sendo desde essa época, em geral, unanimemente positiva. Segundo Laquièze (2003, p. 43), a posição do grupo de Coppet $^{4}$ vai na contramão de todas as concepções sobre o estado de exceção formuladas desde o século XII, apresentando a novidade de sustentar que o quadro legal não pode ser contornado em hipótese alguma, nem mesmo diante do apelo clássico à "salvação pública" (salut public, em francês, ou salus populi, em latim). ${ }^{5}$ Constant seria, assim, o "pai" da concepção forte de império da lei subjacente ao Estado liberal moderno, em ruptura com a tradição anterior da razão de Estado.

Se isso é um título de glória para os liberais e para os inimigos do arbítrio, é também uma matéria de reprovação para teóricos do "político" como Carl Schmitt, quem vê na obra de Constant a negação mesma do político, entendido no âmbito da decisão não derivada de normas jurídicas ou morais prévias. Em O conceito do político, de 1932, o tratado De l'esprit de conquête et de l'usurpation dans leurs rapports avec la civilisation européenne, publicado por Constant em 1814, aparece como o manifesto de uma sociedade na qual a liberdade, o progresso e a razão, em aliança com o comércio, a indústria e a tecnologia, poderiam substituir o Estado, a guerra e a política (SCHMITT, 2007, p. 74-75). A consequência dessa vitória da sociedade comercial sobre a guerreira, louvada por Constant, seria a diluição do político pelo império da lei, o qual coroaria a

\footnotetext{
${ }^{4}$ Referência ao Castelo de Coppet, na Suíça, residência de Jacques Necker e Madame de Staël, servindo como ponto de reunião para um grupo informal de pensadores que envolvia Necker, Staël, Constant e Jean de Sismondi, entre outros.

${ }^{5}$ É nesse sentido que Christian Lynch caracteriza Constant como um "anti-Maquiavel”: "embora reconhecesse a existência de situações de perigo para a sociedade política, Constant negava a conveniência de combatê-lo por medidas excepcionais, alegando que o Estado devia ainda aí observar todas as formalidades prescritas. Tratava-se de uma verdadeira reviravolta na tradição política continental" (LYNCH, 2007, p. 73-74).
} 
racionalização da sociedade moderna celebrada pela ideologia liberal, de modo a escamotear a dimensão da soberania e da decisão, constitutiva do político.

O objetivo desta tese é nuançar essa condenação absoluta do arbítrio da parte de Constant. Não se trata de negar que o autor criticava firmemente o arbítrio - uma hipótese que não resistiria à leitura, mesmo superficial, da obra em questão. $O$ que se trata é de encarar o arbítrio como um verdadeiro problema político que Constant procurou enfrentar ao longo de sua vida, não como um simples mal rejeitado por ele em um plano normativo. Essa mudança de perspectiva borra a posição do autor como alguém que teria expulsado definitivamente a decisão arbitrária do campo da política legítima, seja essa posição utilizada para louvar o "pai” da concepção forte de império da lei subjacente ao Estado liberal moderno, ou para criticar aquele que teria iniciado o movimento liberal de diluição da esfera do político. Na leitura aqui empreendida, Constant se destaca menos por ter condenado implacavelmente o arbítrio, o que era uma espécie de lugar comum no contexto pós-termidoriano, do que por ter percebido o arbítrio como um problema político que continuava premente mesmo após a derrocada do Terror. E, no enfrentamento desse problema político premente, o autor não se contentou com a simples rejeição do arbítrio. Pelo contrário, ele reconheceu a necessidade de o incorporar à vida política de maneira controlada, de modo a se evitar sua deriva tirânica. Assim, sua reflexão prolonga esforços clássicos de conceder um espaço controlado ao inevitável arbítrio na vida política, como a ditadura romana louvada por Nicolau Maquiavel e Jean-Jacques Rousseau e a prerrogativa régia teorizada por John Locke. Sua ruptura com a tradição não consiste em expurgar definitivamente o arbítrio da política, mas em incorporá-lo sob uma chave diferente. Nessa nova chave, o arbítrio não é associado ao estado de exceção nem acessível aos governantes, mas se torna uma parte integrante da vida política regular, ora se encarnando em um poder constitucional específico (o poder neutro, cuja decisão discricionária é desvinculada do governo, da legislação e da aplicação judicial das leis), ora se difundindo no interior do edifício constitucional e se colocando ao alcance de cada indivíduo.

Entender o arbítrio como um problema político enfrentado por Constant implica conceder primazia metodológica à interação dinâmica do autor com a realidade política sobre a qual ele procurou intervir, considerando essa interação como a instância que produz os problemas a serem elaborados no plano teórico. Isso implica, por sua vez, reduzir a ênfase dos últimos grandes intérpretes de Constant na unidade, coerência e 
constância de seu pensamento, atribuindo maior importância justamente às mudanças de posição referidas no início desta Introdução - relatadas, em geral, de modo anedótico, como acidentes da vida pessoal externos à elaboração teórica, ou como simples aplicações dos princípios abstratos, cujo caráter confuso resultaria do ambiente político caótico vivido pelo autor, sem que esse caos se misturasse à coerência e sistematicidade da construção filosófica. Se, ao contrário, considerarmos as ideias do autor como "ideiasforças", no sentido empregado por Gauchet, ou seja, no sentido em que "as representações não se separam da ação no seio da vida coletiva" (GAUCHET, 2018, p. 16), os percalços da prática política não podem ser considerados como externos à elaboração teórica ou como simples tentativas de aplicação dos princípios, mas devem ser abordados como provas que obrigam a teoria a se reformular e adquirir complexidade.

Os livros Le moment Guizot, de Pierre Rosanvallon (1985), e Robespierre: L'homme qui nous divise le plus, de Marcel Gauchet (2018), constituem, nesse sentido, as principais inspirações metodológicas desta tese. Tanto Rosanvallon como Gauchet insistem, no estudo dos personagens e autores políticos examinados (François Guizot e Maximilien de Robespierre, respectivamente), em não separar suas elaborações teóricas de sua prática política, considerando a obra política em questão como "o sistema histórico de sua interação. Uma obra é ao mesmo tempo projeto e prova" (ROSANVALLON, 1985, p. 266-267; ênfases do autor). Contestando a abordagem que separava o grande historiador e teórico político da Restauração, cujo interesse seria intelectual, do ministro inflexível, arrogante e conservador da Monarquia de Julho, cujo interesse seria histórico, Rosanvallon propõe pensar a atuação de Guizot durante a Monarquia de Julho como um teste de seu sistema conceitual formulado durante a Restauração, analisando a deriva intelectual e política do doutrinário com base nessa prova fornecida pela experiência, a qual gerou tensões insolúveis em seu pensamento - notadamente sua "derrapagem moralizadora" (ROSANVALLON, 1985, p. 303) e sua "ruptura com o neutralismo moral do liberalismo" (ROSANVALLON, 1985, p. 304). De modo análogo, Gauchet considera a entrada de Robespierre no Comitê de Salvação Pública como um evento que pôs à prova sua recusa inicial do Poder Executivo, levando-o a reavaliar, perante o teste das circunstâncias, a necessidade de um governo forte, até então negada. Neste caso, "a prática funciona, em poucas palavras, como o recalcado da teoria" (GAUCHET, 2018, p. 136). 
De modo similar, as mudanças de posição de Constant referidas no início desta Introdução não serão consideradas como simples percalços do autor externos a sua elaboração teórica, mas como provas da experiência que lançam novos problemas a sua teoria e a obrigam a se modificar e adquirir complexidade. Ao contrário do estudo de Rosanvallon sobre Guizot e do de Gauchet sobre Robespierre, todavia, essas provas da experiência não resultam, no caso de Constant, em derrapagens intelectuais ou em uma prática que opera como um recalcado da teoria, mas antes em um refinamento do próprio pensamento, o qual se torna mais complexo, mas também mais permeado de tensões e de pontos de um equilíbrio relativamente precário. $\mathrm{O}$ apontamento dessas tensões e desses pontos de equilíbrio relativamente precário não tem o objetivo de diminuir a obra do autor, mas, ao contrário, o de realçar a posição de Constant como um autor que refletiu profundamente sobre as ambiguidades da realidade política sobre a qual procurou intervir e incorporou essas ambiguidades a sua própria teoria, movido pelas provas enfrentadas na experiência prática.

Assim, as mudanças de posição referidas no início desta Introdução servem, nesta tese, como importantes vias de acesso à construção do problema político do arbítrio na obra de Constant. Sua mudança de posição sobre os decretos dos dois terços será interpretada, no Capítulo 1, como o evento que faz o problema do arbítrio emergir em seu pensamento, em conexão com a questão das medidas extraordinárias a serem empregadas para salvar a República de si mesma, se necessário. No Capítulo 2, é o golpe do 18 Frutidor que é interpretado como a prova da experiência que leva o autor a buscar incorporar o arbítrio ao sistema político de modo controlado, após passar o período do Primeiro Diretório (1795-1797) respondendo negativamente à questão, já formulada desde os decretos dos dois terços, da legitimidade de se empregar o arbítrio para superar os perigos que a República encontrava no âmbito de uma opinião pública não necessariamente republicana. A abolição oficial do regime republicano, em 1804, a qual é acompanhada de um afastamento de Constant em relação a seu republicanismo inicial, também será analisada como a fonte de uma reconfiguração do problema do arbítrio na obra do autor. Em um primeiro momento, o afastamento do autor em relação às discussões constitucionais, orientando seu pensamento para uma filosofia política liberal que privilegia os princípios da liberdade individual em relação às formas de governo, desloca o problema do arbítrio, de meio necessário para salvar a República a expediente para contornar a insuficiência das leis e a possibilidade de uma tirania das próprias formas 
legais. É na chave desse deslocamento teórico que serão lidos os Principes de politique de 1806, no Capítulo 3. Por fim, a adesão de Constant à monarquia constitucional, a partir de 1814, será analisada, no Capítulo 4, como fonte de novos desdobramentos do problema do arbítrio. Por um lado, o autor precisará incorporar parte do arbítrio associado à tradição monárquica. Por outro lado, a separação entre a inviolabilidade régia e a responsabilidade dos ministros o levará a desenvolver uma teoria da responsabilidade ministerial como julgamento arbitrário, a qual será considerada como um paradigma da disseminação do arbítrio no interior do edifício constitucional, dotando esse arbítrio da forma do julgamento político. ${ }^{6}$

Em todas essas circunstâncias históricas (estabelecimento da República diretorial em 1795, golpe de Estado republicano em 1797, fim da República em 1804, advento da monarquia constitucional em 1814), a reflexão de Constant não será analisada isoladamente, mas tomando-se o cuidado de reconstituí-la como um ato de fala polêmico, destinado ao debate com posições políticas formuladas na mesma época, muitas das quais foram esquecidas na contemporaneidade. Trata-se da principal contribuição que esta tese toma do contextualismo linguístico de Quentin Skinner, para quem é o estudo do contexto linguístico mais geral sobre o qual intervinha um autor político que pode esclarecer quais eram as intenções do autor ao enunciar seu ato de fala, iluminando assim o que os autores estavam fazendo quando escreveram seus textos tornados clássicos (SKINNER, 1978, p. xiii; SKINNER, 2002a, p. 87).

\footnotetext{
${ }^{6}$ A adesão de Constant a Napoleão durante os Cem Dias será a única mudança de posição elencada no início desta Introdução que não será considerada na tese como fonte de um novo desdobramento no problema do arbítrio. Isso porque é difícil identificar uma verdadeira guinada teórica que teria acompanhado a adesão do autor a Bonaparte. No Capítulo 4, será mencionada a organização da responsabilidade dos ministros no Ato Adicional de 22 de abril de 1815, cuja redação é atribuída a Constant, mas, neste caso específico, parece mais plausível interpretar a redação dessa Constituição como a aplicação de uma teoria política já formulada nos meses anteriores, a qual não é modificada pelo retorno de Napoleão ao poder.
} 
É preciso estabelecer com maior precisão o que se está entendendo por “o problema do arbítrio" na obra de Constant, ainda que apenas a leitura completa da tese possa estabelecer de modo pleno o enquadramento desse problema.

Desde pelo menos o século XVIII, a palavra francesa arbitraire (arbítrio, em português) tem um significado predominantemente pejorativo, tendo passado do sentido de arbitragem ao de despotismo (PORRET, 2016, p. 97). Quando Constant ou, em geral, a maioria de seus contemporâneos expressa a palavra "arbitraire", na maioria das vezes, o objetivo é caracterizar um poder como absoluto, ilimitado e acima das leis, dependendo apenas da vontade caprichosa de um indivíduo ou grupo de indivíduos e de suas paixões desregradas. “Arbitraire” é um sinônimo de absolutismo, despotismo ou tirania.

O fato de a palavra arbitraire já ter um uso espontâneo e consagrado na linguagem não impediu Constant de buscar uma definição teórica para ela, erigindo-a ao status de conceito. Essa definição teórica é buscada em uma de suas primeiras obras, Des réactions politiques, de 1797, em que o arbítrio é definido como "a ausência de regras, de limites, de definições, em suma, a ausência de tudo o que é preciso" (CONSTANT, 1964, p. 72). O arbítrio é definido, acima de tudo, como o oposto dos princípios:

São partidários do arbítrio aqueles que rejeitam os princípios: pois tudo o que é determinado, seja nos fatos ou nas ideias, deve conduzir a princípios; como o arbítrio é a ausência de tudo o que é determinado, tudo o que não é conforme aos princípios é arbitrário.

São partidários do arbítrio aqueles que dizem que há uma distância intransponível entre a teoria e a prática: pois, como tudo o que pode ser precisado é suscetível de teoria, tudo o que não é suscetível de teoria é arbitrário.

Enfim, são partidários do arbítrio aqueles que, pretendendo com Burke que axiomas metafisicamente verdadeiros podem ser politicamente falsos, preferem a esses axiomas considerações, preconceitos, lembranças, fraquezas, tudo o que é vago, indefinível, inconstante, entrando, consequentemente, no domínio do arbítrio (CONSTANT, 1964, p. 72-73).

Em suma, por arbítrio, Constant entende tudo aquilo que não pode ser determinado ou remetido a princípios, que não é suscetível de teorização, que não é regulado por axiomas fixos, mas por considerações vagas, indefiníveis e variáveis. Portanto, se existe um "problema do arbítrio", ele é indissociável do que poderíamos chamar um "problema dos princípios". Grosso modo, ele pode ser assim formulado: É possível remeter toda a vida social, política e moral a princípios fixos e universais?

Em um primeiro momento, o autor busca responder a essa questão de modo positivo, alinhando-se a Immanuel Kant contra Edmund Burke. Na verdade, sua tentativa 
de remeter toda a vida social, política e moral a princípios universais passa por uma reformulação do que lhe parece ser, da parte de Kant, uma maneira demasiadamente inflexível e, portanto, inapropriada de aplicar os princípios à realidade. Constant começa definindo os princípios como "o resultado geral de certo número de fatos particulares" (CONSTANT, 1964, p. 64), insistindo sobre a continuidade entre os planos da generalidade e da particularidade. Sendo uma generalização de fatos particulares, os princípios não são as abstrações metafísicas sem conexão com o real denunciadas por Burke, mas "verdades conectadas umas às outras, e que penetrariam gradualmente até nas aplicações mais circunstanciais, e até nos menores detalhes da vida social, se soubéssemos seguir seu encadeamento" (CONSTANT, 1964, p. 65). "Seguir seu encadeamento" significa, em geral, encontrar os princípios intermediários ou secundários exigidos pela combinação particular em questão. A noção de princípios intermediários permite a Constant se unir a Kant no projeto de um mundo moral e político regido completamente por princípios universais, criticando ao mesmo tempo a tendência do filósofo alemão a aplicar os princípios universais aos casos particulares sem nenhuma mediação, de modo a produzir situações verdadeiramente embaraçosas para os princípios. O conhecido exemplo mobilizado por Constant é o do dever moral de dizer a verdade. Em Des réactions politiques, o autor afirma que esse princípio destruiria a sociedade se fosse tomado de modo absoluto e isolado, como o faz Kant:

Temos a prova disso nas consequências muito diretas que tirou desse princípio um filósofo alemão, que chega a sustentar que, perante assassinos que vos perguntariam se vosso amigo que eles perseguem não está refugiado em vossa casa, a mentira seria um crime (CONSTANT, 1964, p. 68).

A solução para tornar o dever moral de dizer a verdade aplicável consiste em encontrar o princípio intermediário que o torna plausível na situação imaginada, em que assassinos perguntam se alguém que eles perseguem está escondido em sua casa. $\mathrm{O}$ princípio intermediário diz que "dizer a verdade é, assim, um dever apenas para os que têm direito à verdade. Ora, nenhum homem tem direito à verdade que prejudica outrem" (CONSTANT, 1964, p. 69). Kant responde a Constant com seu texto "Sobre um pretenso direito de mentir por humanidade", de 1797, no qual o autor de Des réactions politiques é acusado de romper a universalidade do dever de dizer a verdade ao erigir, sob o falso nome de "princípio intermediário", uma exceção a esse dever moral. Ora, um princípio deixaria justamente de ser um princípio ao comportar uma exceção e deixar de ser universal (KANT, 1967, p. 73). Mas Constant não entende a questão do mesmo modo que Kant. Para ele, os princípios intermediários não constituem exceções aos princípios 
universais, mas modos de os aplicar a situações particulares, sobre as quais a aplicação direta e sem mediação dos princípios universais causaria problemas insolúveis. Os princípios intermediários aparecem como o instrumento que viabiliza a utopia de um mundo moral e político regido completamente por princípios universais. ${ }^{7}$

Alguns intérpretes veem na noção de princípios intermediários uma das principais forças do pensamento de Constant. Holmes, por exemplo, sublinha como essa noção permitiu ao autor formular uma teoria moral capaz de responder aos problemas particulares da França revolucionária, por conceber a possibilidade de conflito entre princípios e se esforçar para tornar as regras morais suscetíveis de compromisso e adaptação a situações concretas (HOLMES, 1984, p. 109). Lynch, por sua vez, enfatiza como os princípios intermediários permitem a Constant fundar novas bases, universalistas, a um liberalismo até então atrelado ao particularismo da experiência histórica britânica, impossível de transpor para a França (LYNCH, 2020, no prelo, p. 210214).

Esta tese tem, entretanto, o objetivo de questionar a ideia segundo a qual os princípios intermediários bastam, segundo Constant, para aplicar os princípios universais a todas as circunstâncias particulares. Embora, em Des réactions politiques, seja sugerida essa possibilidade de remeter todas as circunstâncias particulares a princípios universais por meio dos princípios intermediários, procuraremos mostrar que o autor não passou toda a vida acreditando nessa possibilidade. Pelo contrário, uma dimensão importante de sua teoria procura pensar as situações em que as circunstâncias se mostram impossíveis de serem abarcadas por princípios fixos, tornando-se matéria de uma inevitável decisão.

${ }^{7}$ Nossa interpretação da controvérsia entre Constant e Kant sobre o dever de dizer a verdade contrasta fortemente com outras interpretações fornecidas pela literatura, particularmente com a de Robert J. Benton, quem chega a sugerir que Constant estava reeditando a crítica de Burke à impraticabilidade dos princípios revolucionários - razão pela qual o autor franco-suíço teria sido repreendido por Kant, um defensor da Revolução Francesa (BENTON, 1982). Com o pretexto de contextualizar o controvertido ensaio de Kant "Sobre um pretenso direito de mentir por humanidade”, Benton descontextualiza a atuação de Constant sob o Diretório, como se o autor de Des réactions politiques estivesse trabalhando contra a Revolução Francesa e pela restauração da monarquia (BENTON, 1982, p. 137). Na realidade, Constant era um autor mais próximo de Kant do que de Burke, tanto na avaliação política da Revolução Francesa como na adesão filosófica aos princípios universais. 
É verdade que o projeto de remeter toda a vida social, política e moral a princípios fixos continua sendo afirmado para além das obras de juventude. Não obstante, a partir de certo momento (esta tese vê o golpe do 18 Frutidor como um divisor de águas fundamental, como se verá adiante), essa afirmação do império dos princípios precisa ceder espaço ao reconhecimento da necessidade da decisão. Buscamos compreender como essa problemática surge e se desenvolve no pensamento de Constant, de modo nem sempre harmônico com a afirmação reiterada do império dos princípios. Mais do que tentar estabelecer uma coerência forçada entre essas duas dimensões do pensamento de Constant (o império dos princípios e a necessidade da decisão), interessa-nos a tensão entre elas, reveladora de uma ambivalência da própria ordem política moderna.

Por decisão, estamos entendendo a determinação prática que não pode ser fundada em nenhum princípio fixo, ${ }^{8}$ nem mesmo em um encadeamento de princípios universais e intermediários. Embora a decisão possa ser justificada por argumentos, é impossível compreendê-la como a simples aplicação de um princípio fixo, mesmo supondo que esse princípio fixo se aplica ao mundo com a mediação de princípios secundários. Contrariando o enunciado de Des réactions politiques, Constant discorrerá, ao longo de sua obra, sobre diversas situações que exigem, e diferentes razões que justificam, tomadas de decisão impossíveis de serem vinculadas a princípios fixos. Em geral, essa necessidade de decidir é relacionada ao caráter contingente da política, impossível de ser completamente subsumida por princípios gerais. Esse caráter contingente da política é radicalizado nos momentos de crise política, em que a República, ou a Constituição de modo mais geral, parece ameaçada, e o simples encadeamento entre princípios universais e intermediários é insuficiente para sua salvação. A ênfase sobre o caráter contingente da política leva Constant a sublinhar a insuficiência da lei como guia universal das ações humanas - uma insuficiência que pode ser moral ou política, como veremos, e que é indissociável de um apelo à decisão que não se funda nas leis, podendo chegar a contrariálas.

Todas essas situações em que os princípios e as leis (princípios dotados de um lastro jurídico oficial) se revelam insuficientes, e os agentes morais e políticos são

${ }^{8}$ Em sua definição dos princípios, Constant nota que eles podem ser mais ou menos gerais, de acordo com a posição que ocupam no encadeamento entre princípios universais e intermediários, mas sua característica invariável é a fixidez: "a essência de um princípio não é ser geral, nem aplicável a muitos casos, mas ser fixo" (CONSTANT, 1964, p. 65). 
chamados a decidir, autorizam a postulação de um decisionismo inerente ao pensamento de Constant, o qual é sugerido no título desta tese. Como se sabe, o conceito de decisionismo é associado à obra de Carl Schmitt, o mais eminente representante, no século XX, da tradição que vê na decisão concebida como vontade soberana o fundamento da ordem política (BERNARDI, 2013, p. 10-11). Como esclarece Philippe Urfalino (2019, p. 301), o conceito político de decisionismo é fortemente associado à afirmação do jurista alemão segundo a qual o soberano é aquele que decide sobre o estado de exceção, porém o decisionismo de Schmitt remete antes a seus primeiros trabalhos sobre o julgamento de Direito, nos quais se afirma que esse julgamento não pode derivar da simples subsunção do caso sob a norma a ser aplicada pelo juiz, este último precisando introduzir uma decisão discricionária para chegar ao julgamento a partir do estado do Direito e do caso a julgar.

Schmitt radicalizou e generalizou essa tese, para fazer da decisão e da
autoridade a fonte, e não a consequência, do Direito. Fora do domínio jurídico,
o termo "decisionismo" designa uma concepção particular da relação entre
decisão e raciocínio prático, segundo a qual a decisão não pode ser a simples
conclusão do raciocínio; ela exige um ato de vontade, exterior à racionalidade,
o qual preenche a eventual indeterminação do raciocínio e, sobretudo, assegura
a passagem do raciocínio à ação (URFALINO, 2019, p. 301-302).

Tomado nesse sentido largo, o conceito de decisionismo abarca bem o aspecto do pensamento de Constant sobre o qual esta tese objetiva chamar a atenção: a necessidade de que agentes políticos e morais tomem decisões que não derivam diretamente de princípios. Esse decisionismo está presente no pensamento do autor franco-suíço mesmo sem a radicalização e a generalização promovidas por Schmitt e mencionadas por Urfalino, as quais resultam na definição do soberano como aquele que decide sobre o estado de exceção, com todas as conhecidas consequências autoritárias desse postulado.

Como aprofundaremos na Conclusão, esta tese se propõe a explorar, na obra de Constant, um paradigma da decisão política diferente do de Schmitt, mas distinto também do da escolha racional utilitarista, o outro grande paradigma da decisão encontrado na tradição da teoria política (BERNARDI, 2013, p. 8-9). A decisão constantiana é aquela que abre uma porta para o julgamento político, bloqueado por um decisionismo como o de Schmitt (URFALINO, 2019, p. 309). Apesar dessa distinção fundamental entre o decisionismo de Constant e o de Schmitt, o jurista alemão foi um dos poucos teóricos políticos a jogar luz explicitamente sobre o aspecto da obra do autor franco-suíço que esta tese pretende explorar. Apesar da caricatura de Constant apresentada em $O$ conceito do político, um uso diferente de nosso autor é realizado em $O$ guardião da Constituição (Der 
Hüter der Verfassung), de 1931. Em sua crítica do controle jurisdicional da constitucionalidade das leis defendido por Hans Kelsen, ${ }^{9}$ Schmitt invoca a autoridade intelectual de Constant, um autor que teria percebido que o guardião da Constituição deve ser uma autoridade discricionária, não sujeita à limitação das formas legais. O jurista alemão mobiliza a doutrina do poder neutro formulada pelo autor franco-suíço para fundamentar a faculdade de ação discricionária atribuída ao presidente do Reich em um estado de emergência, no quadro da Constituição de Weimar (SCHMITT, 2015, p. 150160). ${ }^{10}$ Seria difícil sustentar que Constant aprovaria a finalidade política de sua apropriação retórica por parte de Schmitt. O que importa sublinhar, todavia, é que o jurista alemão prestou atenção a um aspecto até hoje pouco enfatizado no pensamento de Constant: a necessidade de incorporar politicamente a discricionariedade, não apenas no âmbito da ação do poder neutro, mas também no da responsabilidade dos ministros (SCHMITT, 2015, p. 96-97). ${ }^{11}$ Esta tese tem a intenção de explorar esse aspecto de Constant que despertou o interesse de Schmitt, em detrimento do Constant mais convencional apropriado pela tradição liberal, o qual é apresentado muitas vezes, anacronicamente, como um "pai" da democracia liberal contemporânea. ${ }^{12}$

\footnotetext{
${ }^{9}$ Sobre esse debate entre Kelsen e Schmitt, ver: PASQUINO, 1994a; VINX, 2015.

${ }^{10}$ Não é apenas Constant, mas a tradição liberal francesa do final do século XVIII e da primeira
} metade do XIX, de modo mais amplo, que Schmitt mobiliza para demonstrar a insuficiência da guarda da Constituição concebida na forma do controle jurisdicional da constitucionalidade das leis. Além de Constant, as autoridades intelectuais de Emmanuel Joseph Sieyès e François Guizot são mobilizadas (SCHMITT, 2015, p. 105). Tratava-se de uma tradição intelectual para a qual "a estabilidade política era primeira condição da estabilidade normativa" (LYNCH, 2007, p. 75), sendo impossível substituir a decisão discricionária de um órgão político interessado na conservação da Constituição por um controle jurisdicional da constitucionalidade das leis concebido em moldes técnicos.

${ }^{11}$ Embora Schmitt se aproprie dessa dimensão do pensamento de Constant, seu decisionismo bebe mais diretamente de uma corrente política antagônica à do autor liberal: a tradição contrarrevolucionária católica de Joseph de Maistre, Louis de Bonald e Juan Donoso Cortés (SCHMITT, 2005, Cap. 4). Maistre, em especial, pode ser considerado como o grande teórico decisionista da época de Constant (cf. BRAHAMI, 2016, p. 170). Apesar de seu pertencimento a campos políticos antagônicos, esta tese fará uma aproximação, no Capítulo 4, entre as teorias da monarquia de Constant e de Maistre.

12 “Não é ele o primeiro grande pensador da democracia liberal?”, indaga Todorov (1997, p. 9). $\mathrm{Na}$ perspectiva desta tese, explicitada na Conclusão, Constant pode sim ser considerado como um dos primeiros grandes pensadores da democracia liberal, porém, apenas se entendermos por isso um autor que refletiu profundamente sobre as antinomias fundamentais desse regime político então em estado embrionário, não um simples defensor ou apologista desse regime. 
Referimo-nos acima à incorporação política da discricionariedade por parte de Constant. É importante destacar que o autor distinguiu explicitamente uma autoridade discricionária de uma autoridade ilimitada - duas noções que teriam sido confundidas na experiência política francesa: “Todos os governos precisam de uma autoridade, não ilimitada, mas discricionária. Essas duas coisas foram confundidas; e, dessa confusão, resultaram muitos males" (CONSTANT, 1991, p. 451). Portanto, essa incorporação política da discricionariedade não leva Constant a admitir o arbítrio em seu sentido convencional, ou seja, como governo absoluto, ilimitado, despótico ou tirânico. No entanto, como vimos, o arbítrio é definido pelo autor como a simples ausência de definições ou determinações precisas, como a decisão impossível de submeter a uma teorização ou de remeter a princípios fixos. Assim, a decisão discricionária que, segundo esta tese, é inerente ao pensamento de Constant está no coração daquilo que estamos chamando de "problema político do arbítrio". Este problema nada mais é, em um primeiro plano, do que o reconhecimento da impossibilidade de submeter todas as circunstâncias particulares a princípios fixos, de modo a suprimir a esfera da decisão.

Pode parecer estranho falar em um problema do arbítrio para Constant, em vez de uma simples rejeição do arbítrio, uma vez que o autor nem sempre é fiel a sua própria definição de arbítrio, utilizando recorrentemente a palavra em seu sentido convencional de governo absoluto e ilimitado e, neste sentido, mantendo ao longo de sua obra uma rejeição categórica do arbítrio. Porém, é preciso ter em vista que, em situações em que a palavra arbitraire é evitada em função de sua conotação negativa, o autor preferindo, por exemplo, a palavra discrétionnaire, é o problema do arbítrio que está em jogo mesmo na ausência da palavra, de acordo com a definição do arbítrio como "a ausência de regras, de limites, de definições, em suma, a ausência de tudo o que é preciso". Ao longo da tese, serão fornecidos exemplos que demonstram um uso quase intercambiável das palavras arbitraire e discrétionnaire por parte de Constant. ${ }^{13}$ Em alguns casos pontuais, as

${ }^{13}$ Um exemplo, fornecido no Capítulo 2 desta tese, é uma passagem de Des suites de la contrerévolution de 1660 en Angleterre, de 1799, na qual Constant cita um trecho de History of England de David Hume, em que o filósofo e historiador escocês se refere a uma lei que permitia ao Rei da Inglaterra escolher arbitrariamente a punição a determinados tipos de crime. No trecho, que Constant reproduz em inglês em sua obra, Hume afirma que as cortes penais, ao delegar ao Rei a escolha da punição, "determinavam que a punição seria arbitrária [arbitrary]" (HUME apud CONSTANT, 1998a, p. 660; ênfase nossa). Na paráfrase quase literal feita em francês, contudo, o autor escreve: "proibir uma ação, sem anexar à 
palavras aparecem juntas. Assim, nos Fragments: "É preciso que essa autoridade discricionária não se aplique nunca sobre os homens, porque os homens devem estar sempre protegidos contra o arbítrio" (CONSTANT, 1991, p. 451). O texto De la responsabilité des ministres, de 1815, pode ser considerado aquele em que a palavra arbitraire aparece como um traço necessário do processo político de modo mais explícito, o autor afirmando que entrega os ministros "a uma espécie de arbítrio exercido sobre eles, tanto por seus acusadores como por seus juízes. Mas esse arbítrio está na essência mesma da coisa" (CONSTANT, 2001, I, p. 461).

O problema do arbítrio pode estar presente mesmo quando as palavras arbitraire e discrétionnaire estão ausentes. Para que o problema do arbítrio esteja presente, basta a existência de uma vontade que decide sem que essa decisão seja fundada em princípios ou leis fixados de antemão. Assim, no Capítulo 3, o problema do arbítrio será relacionado à possibilidade, vislumbrada por Constant, de que jurados ou detentores do direito de graça se interponham à execução literal da lei, quando percebem nessa aplicação da lei uma possível fonte de injustiça. Mesmo que o autor não utilize, nesse caso, a palavra arbitraire, essa palavra é utilizada por autores dos séculos XVIII e XIX críticos do direito de graça, como Cesare Beccaria e Jeremy Bentham, os quais chamam de arbitrária a intromissão de uma vontade deliberante que atrapalha a execução literal da lei. O fato de Constant travar um diálogo crítico com Beccaria e Bentham situa sua discussão sobre o júri e o direito de graça no âmbito do que estamos chamado de "problema do arbítrio". Em outras palavras, o contexto linguístico em que Constant se situa nos ajuda a definir o problema do arbítrio, para além da acepção comum do arbítrio como governo absoluto e ilimitado.

O reconhecimento da impossibilidade de submeter todas as circunstâncias particulares a princípios fixos, reconhecimento este que institui o âmbito da decisão como necessário, constitui, portanto, o problema do arbítrio. No entanto, o arbítrio só se torna verdadeiramente um problema quando acompanhado do desafio de não converter a decisão em porta para o arbítrio entendido no sentido de tirania, ou poder absoluto e ilimitado. Constant se revela preocupado em incorporar a decisão a sua teoria política, mas jamais a decisão absoluta referida por Schmitt, aquela autorizada a suspender a lei

transgressão dessa lei uma pena legal, era conferir ao Rei um poder discricionário [discrétionnaire] sobre o criminoso" (CONSTANT, 1998a, p. 660; ênfase nossa). 
no estado de exceção e reinar como soberana (cf. SCHMITT, 2005, p. 12). É por isso que esta tese caracteriza o decisionismo de Constant como moderado. Ao contrário de Schmitt, sua preocupação não é apenas realçar a decisão como um componente fundamental do político, mas impedir que essa decisão suspenda o império das leis e abra caminho para a elevação de uma autoridade ilimitada, da espécie que o jurista alemão via como intrínseca ao estado de exceção. ${ }^{14}$ É neste sentido que o arbítrio e a decisão são, para Constant, um problema, algo que dificilmente poderíamos dizer a respeito de Schmitt, cuja não problematização do poder absoluto fez com que sua obra, apesar de "provocar uma reflexão instigante sobre a natureza do político", não oferecesse "um obstáculo convincente aos riscos proporcionados pelo recurso aos instrumentos extremos da vida política” (BIGNOTTO, 2008, p. 415).

Assim, o problema do arbítrio, visto por este novo ângulo, não é mais apenas o de como decidir quando as circunstâncias não podem ser remetidas a princípios fixos, mas também o de como impedir a degeneração dessa decisão discricionária em tirania. Como veremos no Capítulo 1, outros autores da tradição do pensamento político ocidental também podem se enquadrar na categoria de "decisionismo moderado", no sentido em que buscaram ceder um espaço ao arbítrio, sem com isso comprometer o império da lei ou submetê-lo aos riscos oferecidos por um decisionismo como o de Schmitt. A particularidade de Constant está em seus novos esforços para impedir a degeneração do arbítrio incorporado em tirania, segundo o diagnóstico de que mecanismos como a ditadura romana ou a prerrogativa lockeana são insuficientes neste sentido. O primeiro esforço de Constant será para isolar e concentrar o arbítrio, alocando-o em um poder constitucional em que a decisão discricionária fica separada de qualquer participação no governo, na legislação e na aplicação judicial das leis. Em um segundo momento, sua démarche será a disseminação do arbítrio no interior do edifício constitucional e sua colocação ao alcance de cada indivíduo.

Desse modo, Constant legou à posteridade uma maneira inédita de abordar o problema do arbítrio e da decisão, a qual permanece instigante e atual.

14 “O que caracteriza uma exceção é principalmente uma autoridade ilimitada, o que significa a suspensão de toda a ordem existente" (SCHMITT, 2005, p. 12). 
O ressurgimento de um interesse intelectual pela obra de Constant já tem pelo menos quatro décadas. Não se trata aqui de realizar um balanço bibliográfico exaustivo da relativamente vasta literatura sobre o autor produzida nesses últimos quarenta anos, mas de indicar as principais tendências que conformam o "estado da arte" da leitura atual de Constant, no mundo e no Brasil.

Entre as décadas de 1950 e de 1980, o nome de Constant foi estreitamente associado ao de Isaiah Berlin, o intelectual russo-britânico cujo ensaio "Dois conceitos de liberdade", publicado em 1958, com base em uma palestra proferida na Higham Chichele Society, foi visto como a atualização da conferência "Da liberdade dos antigos comparada à dos modernos", proferida por Constant em 1819, no Athénée royal de Paris, no contexto de um curso sobre a constituição inglesa. Berlin retrata Constant como um dos autores que expressaram mais claramente, na história do pensamento político ocidental, o conflito entre as duas concepções de liberdade opostas em seu ensaio: as liberdades negativa e positiva (BERLIN, 2002, p. 209). Desde então, tornou-se comum encarar o autor franco-suíço como um defensor da liberdade negativa, compreendida como ausência de interferência, contra a liberdade positiva característica da tradição republicana, entendida na chave do engajamento cívico e do autogoverno coletivo. "Da liberdade dos antigos comparada à dos modernos" se tornou um dos textos mais lidos de Constant, tido como a chave para todo o seu pensamento, e essa conferência passou a ser interpretada como formando um conjunto com "Dois conceitos de liberdade" de Berlin: em ambos os casos, tratar-se-ia de defender a liberdade negativa contra a positiva, a independência individual contra a participação política, a ausência de interferência contra o autogoverno. ${ }^{15}$

${ }^{15} \mathrm{O}$ reducionismo foi acentuado não apenas pela redução de toda a obra de Constant à conferência de 1819, mas também pela frequente redução da obra de Berlin ao ensaio de 1958. Segundo Ivo Coser, "Dois conceitos de liberdade" "viria a ser o trabalho de Berlin mais conhecido. Em parte, essa difusão obscureceu seu argumento, reduzindo-o a um confronto simples entre as liberdades positiva e negativa" (COSER, 2019, p. 1). Para Coser, Berlin não é um defensor da liberdade negativa como fim único da sociedade, pois sua ideia central é o pluralismo de valores, com base no qual a liberdade positiva também pode ser considerada como um fim legítimo a ser conciliado com a liberdade negativa. "A crítica de Berlin 
É principalmente na década de 1980 que essa leitura "berliniana" de Constant começa a ser abalada. Como nota Helena Rosenblatt, "tratamentos de Constant mais atentos a seu contexto histórico e a sua mensagem intencionada mostraram que ele escreveu esse ensaio, não para denunciar a liberdade positiva e a participação política, mas para alertar contra seu declínio" (ROSENBLATT, 2004, p. 4). Mais atenção passou a ser dirigida para o final da conferência de 1819, na qual o autor alerta para os perigos do individualismo e da apatia política, louva a participação política como o melhor meio de aperfeiçoamento do ser humano e conclui: "Longe, pois, Senhores, de renunciar a alguma das duas espécies de liberdade de que vos falei, é preciso aprender a combinálas" (CONSTANT, 1985, p. 7). O livro de Stephen Holmes, Benjamin Constant and the making of modern liberalism (1984), teve como objetivo central desfazer "o mito de um conflito intratável entre liberalismo e democracia" (HOLMES, 1984, p. 2), ressaltando que a liberdade individual era compreendida por Constant como indissociável de um quadro democrático de liberdade política e de alta participação cívica. $\mathrm{O}$ autor francosuíço é, assim, retirado do quadro de referências da oposição entre liberdade negativa e positiva consagrada por Berlin, dentro do qual ele parecia o apologista de uma liberdade individual que poderia ser gozada independentemente da democracia. Autoras como Biancamaria Fontana e Annelien de Dijn reforçaram a ruptura com a leitura berliniana de Constant ao o classificarem como republicano, ou neorrepublicano (FONTANA, 1991, p. 64-66; DIJN, 2008, p. 101).

Na França, o ressurgimento de interesse por Constant, a partir da década de 1980, não se centrou tanto na refutação da leitura berliniana, embora trabalhos como L'individu effacé, de Lucien Jaume (1997), e Benjamin Constant: La passion démocratique, de Tzvetan Todorov (1997), também tenham contribuído para abalar essa leitura, realçando o esforço do autor franco-suíço para conectar a liberdade individual ao engajamento cívico na esfera pública. No contexto francês, a "redescoberta" de Constant esteve ligada ao "liberal revival" que se seguiu às críticas do totalitarismo (especialmente de sua versão comunista) formuladas na década de 1970 (LILLA, 1994; CHRISTOFFERSON, 2004). Uma das maiores expressões desse "momento antitotalitário" francês, François Furet foi um dos primeiros a resgatar o interesse intelectual por Constant, explorando

não incidia sobre a liberdade positiva tout court, mas sobre a sua distorção" (COSER, 2019, p. 6). A perspectiva de uma conciliação entre duas espécies de liberdade tratadas inicialmente como antagônicas pode propiciar uma reaproximação entre Constant e Berlin, sobre novas bases. 
principalmente sua crítica do Terror, mobilizada para fundamentar seu próprio revisionismo crítico da Revolução Francesa (FLORENZANO, 2001, p. 177; ROSENBLATT, 2004, p. 6-8). Na esteira de Furet, Marcel Gauchet se interessa por Constant como um dos primeiros teóricos da "gênese convulsiva e dificilmente controlável do fato democrático, na forma muito particular de que ela se revestiu na França, e com as dificuldades originais que ela encontrou nesse país" (GAUCHET, 1997, p. 24), o estudo do autor franco-suíço permitindo "um começo de resposta às aporias devastadoras da modernidade" (GAUCHET, 1997, p. 28). Gauchet ressalta a lucidez de Constant como formulador de uma teoria pioneira sobre a grande revolução moderna, cujas linhas gerais influenciam sua própria visão sobre o advento da modernidade, mas sublinha também a ilusão inscrita em seu liberalismo, incapaz de perceber que a expansão da zona de independência individual era correlativa de um movimento paralelo de crescimento das funções do Estado (GAUCHET, 1997, p. 85-86). Porém, na figura do poder neutro, o autor franco-suíço teria reconhecido a insuficiência da sociedade de indivíduos produtora do poder político por delegação, clamando pela necessidade de "conferir figura e corpo a um lugar de poder exterior à vontade dos homens, em referência ao qual a sociedade se produz, constitui-se como um conjunto capaz de se corresponder consigo mesmo" (GAUCHET, 1997, p. 104). Em suma, no contexto "antitotalitário" francês, Constant foi lido como um teórico do político produtor do social. ${ }^{16} \mathrm{~A}$ leitura de Pierre Manent se dá em diálogo próximo com a de Gauchet, ressaltando igualmente que liberais como Constant "estavam debruçados sobre as articulações fundamentais das sociedades modernas" (MANENT, 1980, p. 484), mas apontando também as insuficiências desse liberalismo na prevenção dos perigos que rondam as sociedades liberais (MANENT, 1980, p. 484). O debate entre as interpretações de Manent e de Gauchet ocorre sobretudo a respeito do peso respectivo das tradições políticas antiga e moderna para o engendramento dos perigos à liberdade apontados por Constant - um debate vinculado à interpretação mais geral do totalitarismo (MANENT, 1980, p. 488-

${ }^{16}$ Sobre o interesse dos fundadores do Institut Raymond Aron (François Furet, Marcel Gauchet, Pierre Manent, Pierre Rosanvallon, entre outros) - matriz do atual Centre d'Études Sociologiques et Politiques Raymond Aron (CESPRA) - pela dimensão do "político", ver: JENNINGS, 1997; LYNCH, 2010. 
490; MANENT, 2012, p. 189, nota 9) - e do peso respectivo das autoridades da História e da natureza para a fundamentação de seu liberalismo (MANENT, 2012, p. 182-184). ${ }^{17}$

No Brasil, a bibliografia específica sobre Constant ainda é bastante incipiente, esta tese se propondo a contribuir para a incrementação dos estudos sobre esse autor fundamental não só na história do pensamento político moderno, mas também na do pensamento político brasileiro do século XIX. Grosso modo, predomina ainda na academia brasileira a leitura berliniana de Constant, a maioria dos estudantes de ciência política e filosofia tendo acesso apenas a "Da liberdade dos antigos comparada à dos modernos", e aprendendo a ver nessa conferência a defesa da "liberdade negativa" contra a "liberdade positiva" sistematizada posteriormente por Berlin. ${ }^{18}$ Vale notar, todavia, algumas exceções que têm trazido um conhecimento mais preciso de Constant para a comunidade acadêmica brasileira.

Em primeiro lugar, cabe destacar os estudiosos do pensamento político brasileiro do século XIX que discutem Constant principalmente em função da recepção importante que ele teve no Brasil oitocentista. Nessa agenda de pesquisa, tem primazia a teoria constantiana do poder neutro, a principal inspiração do Poder Moderador inscrito na Constituição brasileira de 1824. Não há espaço para fazer aqui um balanço da vasta bibliografia sobre o Poder Moderador brasileiro e seus fundamentos teóricos nos escritos de Constant. Contentamo-nos em citar a tese de Christian Edward Cyril Lynch, $O$ momento monarquiano: O Poder Moderador e o pensamento político imperial (2007), e a dissertação de Diego Rafael Ambrosini, Do Poder Moderador: Uma análise da organização do poder na construção do Estado imperial brasileiro (2004). Embora tendo um objeto de estudo diferente, a tese de Lynch traz informações importantes para esta tese, na medida em que também busca situar o poder neutro de Constant no quadro do "problema teórico da discricionariedade regulada do poder soberano" (LYNCH, 2007, p.

${ }^{17}$ Sobre os modos diferentes como Gauchet e Manent interpretam a articulação das autoridades da História e da natureza no pensamento de Constant, ver: GHELERE, 2008, p. 41-42.

18 Por ocasião do evento "200 anos de Da liberdade dos antigos comparada à dos modernos, de Benjamin Constant: Que liberdade para os tempos modernos?”, realizado em 2019 na Universidade de São Paulo, Newton Bignotto comentou, em sua fala "Benjamin Constant e o liberalismo contemporâneo francês: Pierre Manent e Marcel Gauchet", que a comunidade acadêmica brasileira ainda estava muito impregnada pela leitura de Constant recebida de Berlin, sugerindo a oportunidade de se abrir às leituras de Manent e Gauchet. 
20). Em As fundações do pensamento político brasileiro (no prelo), o mesmo autor faz Constant aparecer como figura de proa da construção intelectual do Estado de Direito na França, trazendo reflexões que dialogam com o objeto desta tese.

Do ponto de vista de teses e dissertações brasileiras específicas sobre o pensamento de Constant, recebe destaque a dissertação de Gabriela Doll Ghelere, $A$ liberdade individual para Benjamin Constant. O foco é o clássico debate sobre a liberdade individual tendo como pano de fundo a conferência de 1819 sobre a liberdade dos antigos e dos modernos, mas a autora incorpora as contribuições de Gauchet, Manent e Todorov, de modo a reduzir o peso da leitura berliniana convencional e enfatizar a importância da participação política para Constant, em sintonia com as interpretações mais atualizadas.

A tese de Paulo Henrique Paschoeto Cassimiro, O Abismo do Tempo: História, Liberalismo e Democracia no Pensamento Político Francês (1789-1848) (2016), bebe das interpretações do liberalismo francês formuladas pela "escola francesa do político" (Furet, Gauchet, Manent, Rosanvallon, etc.), fazendo essas interpretações dialogarem com as categorias erigidas por Reinhart Koselleck para descrever as mutações do conceito de História típicas da modernidade. Resulta disso uma leitura de Constant muito mais aprofundada do que as comumente em voga no Brasil. Entretanto, o esforço de situar o autor franco-suíço em uma corrente política mais vasta, o "liberalismo francês", acaba obscurecendo alguns pontos de tensão de sua obra e de sua trajetória. Por exemplo, preocupado com um conceito de liberalismo que contemple ao mesmo tempo Constant, Guizot e Tocqueville, Cassimiro escreve que "o liberalismo nega a soberania do povo" (CASSIMIRO, 2016, p. 209) - o que pode ser verdade para Guizot, mas não para Constant e Tocqueville. Nesta tese, a aceitação do princípio da soberania do povo por parte de Constant será crucial para entender a emergência do problema do arbítrio em seus primeiros escritos sob o Diretório. Assim, acreditamos que uma tese que se debruça especificamente sobre a obra de Constant, deixando de lado a narrativa mais ampla sobre o liberalismo francês, tem uma capacidade maior de aprofundar os pontos de tensão presentes no pensamento do autor, preenchendo uma lacuna na literatura mais geral sobre o liberalismo.

Ainda no campo das teses brasileiras em que Constant é tratado sem ser o objeto principal, vale mencionar a tese de Thais Florencio de Aguiar, Uma genealogia de princípios de demofilia em concepções utópicas de democratização (2013). Nessa tese, o 
autor é tratado como um dos primeiros representantes da "demofobia" característica da tradição liberal, da "crença na impossibilidade de o povo governar-se" (AGUIAR, 2013, p. 26) inscrita na teorização da própria democracia, como um resultado do medo que as classes detentoras do poder político possuíam da ascensão das multidões. Guiada metodologicamente por uma concepção de genealogia inspirada na obra de Michel Foucault, a tese de Aguiar não se preocupa em indagar, à maneira de Skinner, o que Constant e outros liberais estavam fazendo quando publicaram seus respectivos textos. Intérpretes do autor mais preocupados em compreender sua interação com seu contexto histórico têm sublinhado, contra a leitura "demofóbica", que "o pensamento de Constant estava certamente mais preocupado em avançar a democracia do que em contê-la" (ROSENBLATT, 2004, p. 8). Admirador de Rousseau e da obra da Revolução Francesa, os principais embates teóricos e políticos do autor franco-suíço foram no sentido de defender o princípio da soberania do povo como compatível com a liberdade e louvar a marcha da História em direção à igualdade. Seu alvo não eram os "excessos" da democracia, mas a apropriação hipócrita do princípio da soberania do povo por tiranos como Robespierre e Napoleão, que excluíam o povo do poder em nome de sua soberania (ROSENBLATT, 2004, p. 8). Mesmo em relação à defesa de um critério de propriedade para a inclusão no direito de voto - a razão pela qual Aguiar considera Constant como demofóbico (AGUIAR, 2013, p. 28-31) -, Fontana argumenta que, no contexto em que o autor franco-suíço escreveu, "todas as suas intervenções políticas foram consistentemente a favor de ampliar, em vez de limitar, a base eleitoral" (FONTANA, 1991, p. 77). Afinal, o critério de propriedade defendido por Constant incluía um número de eleitores muito superior ao vigente sob Napoleão e sob a Restauração, e, de 1815 a 1830, o autor militou pela eleição direta (adotada em 1817, em substituição ao sistema de eleição em dois graus) e contra os projetos que aumentavam a influência eleitoral dos grandes proprietários (FONTANA, 1991, p. 77-78).

Em suma, uma tese preocupada em situar a ação intelectual e política de Constant em seu contexto histórico não pode concordar com sua caracterização como teórico "demofóbico". Isso não significa que a problematização dos elementos elitistas que a teoria democrática moderna herdou dos últimos séculos seja irrelevante. É justamente essa problematização que torna a tese de Aguiar instigante, apesar de sua inadequação do ponto de vista de uma metodologia contextualista. É historicamente equivocado afirmar que Constant era demofóbico, porém é verdade que ele viveu em uma época em que eram 
aceitas restrições ao princípio de igualdade não mais aceitas nas democracias contemporâneas, como o sufrágio censitário. Assim como, para o historiador, é infrutífero julgar o passado com base no presente, para o teórico político, é problemático transformar uma teoria política formulada em um passado mais elitista em um padrão normativo para a contemporaneidade. É por isso que, evitando as abordagens normativas, esta tese não pretende fazer do pensamento de Constant um modelo normativo para a democracia contemporânea - uma ideia que poderia ser sugerida pela negação de seu caráter demofóbico. A principal contribuição teórica do Constant explorado por esta tese é, como desenvolveremos na Conclusão, a possibilidade de repensar o conceito de decisão política. Como veremos no Capítulo 4 , a decisão discricionária pode vir tanto de um júri (contexto em que Constant mobiliza o argumento democrático do elogio da razão do "homem comum") como de uma Câmara dos Pares hereditária (ocasião em que o autor mobiliza o argumento aristocrático das virtudes intrínsecas a uma posição social e política eminente). Do ponto de vista desta tese, não importa determinar se predominava o Constant popular ou o elitista, ou se têm mais razão seus seguidores ou seus detratores. Importa-nos o argumento da decisão política: o contexto pós-revolucionário tornava possível, ou mesmo necessário, que esse argumento fosse sustentado com base em considerações tanto democráticas como aristocráticas.

Esse breve balanço bibliográfico teve a intenção de demonstrar a oportunidade de uma tese específica sobre Benjamin Constant, no contexto de um intercâmbio acadêmico entre a Universidade de São Paulo e o Centre d'Études Sociologiques et Politiques Raymond Aron (CESPRA) da École des Hautes Études en Sciences Sociales (EHESS), e tendo por objeto o problema do arbítrio e da decisão - tema raramente tratado de modo sistemático na literatura disponível sobre Constant. ${ }^{19}$

${ }^{19}$ O artigo de Gabriel Afonso Campos, "Poder Neutro e razão de Estado em Benjamin Constant" (CAMPOS, 2019), aproxima-se do problema desta tese ao relacionar o poder neutro de Constant com o conceito de razão de Estado. A ideia de "razão de Estado mitigada" (CAMPOS, 2019, p. 16) poderia ser comparada com a de "decisionismo moderado", empregada por esta tese. Cabe salientar, contudo, que esta tese analisa o decisionismo moderado de Constant em um âmbito mais vasto do que o do poder neutro, alargando o problema do arbítrio e da decisão para além do da preservação do sistema político vigente, terreno das teorias clássicas da razão de Estado. 
O Capítulo 1 almeja compreender de que modo o problema do arbítrio emerge no pensamento do jovem Constant sob o Primeiro Diretório (1795-1797), em um diálogo crítico com autores que propomos interpretar pela categoria de "liberalismo da ordem"notadamente Pierre-Louis Roederer e Adrien de Lezay-Marnésia. Embora a primeira resposta de Constant ao problema do arbítrio tenha sido sua rejeição incondicional, argumentamos, no Capítulo 2, que essa rejeição é reavaliada após o golpe de Estado do 18 Frutidor do Ano V, e que essa reavaliação culmina na formulação da ideia do poder neutro como uma "autoridade discricionária". No Capítulo 3, examinamos a nova configuração do problema do arbítrio proporcionada pela "virada liberal" dos Principes de politique de 1806, procurando mostrar que, por um lado, o arbítrio é condenado sobre novas bases, mas que, por outro lado, a decisão arbitrária passa a ser disseminada no interior do edifício constitucional, na forma de múltiplas instâncias em que a lei pode ser contornada ou contrariada, a fim de evitar a tirania da lei excessiva. Por fim, o Capítulo 4 trata do lugar do arbítrio na monarquia constitucional teorizada por Constant a partir de 1814, analisando as novas nuances da versão monárquica do poder neutro e a interpretação da responsabilidade dos ministros como um julgamento inevitavelmente arbitrário. A Conclusão ressalta Constant como um eminente teórico da decisão e do arbítrio, buscando discernir em sua obra um paradigma da decisão alternativo em relação aos já estabelecidos na teoria política. 


\section{Capítulo 1: A Revolução Francesa já terminou? Benjamin Constant e o liberalismo da ordem}

O objetivo deste capítulo é situar a emergência daquilo que estamos chamando de problema do arbítrio no pensamento de Constant sob o Primeiro Diretório (1795-1797), por um lado, em relação à filosofia política moderna tomada de modo mais geral, e, por outro lado, em relação às correntes político-intelectuais mais influentes no contexto específico do Diretório.

A Seção 1.1 procura estabelecer, em linhas gerais, a evolução do problema do arbítrio na filosofia política moderna anterior ao momento em que Constant faz sua entrada na cena política e intelectual francesa. ${ }^{20} \mathrm{O}$ objetivo é mostrar que, mesmo quando, nos séculos XVII e XVIII, ganha força o ideal de império da lei e de um Poder Executivo subordinado ao Legislativo, autores comprometidos com esse ideal continuam sugerindo a existência de um "problema do arbítrio", ou seja, de situações que não podem ser resolvidas pelo simples apelo às leis, o que exige a decisão discricionária de alguma autoridade extralegal. É sob esse prisma que serão analisados a discussão de John Locke sobre a prerrogativa régia e o elogio de Jean-Jacques Rousseau à instituição romana da ditadura (retomando uma temática já tratada por Nicolau Maquiavel). Em seguida, será examinado o tratamento do problema do arbítrio nos anos iniciais da Revolução Francesa (de 1789 a 1794), procurando-se compreender como os primeiros revolucionários franceses articularam duas posturas aparentemente contraditórias em relação ao arbítrio: por um lado, a rejeição de qualquer decisão discricionária por parte dos poderes Executivo e Judiciário, toda vontade política ativa que vai além da simples aplicação da lei aparecendo como ilegítima; por outro lado, a admissão do arbítrio no contexto do estado de exceção, o qual se torna absoluto à medida que a Revolução se radicaliza.

A Seção 1.2 apresenta Pierre-Louis Roederer e Adrien de Lezay-Marnésia como dois autores particularmente influentes no debate político-intelectual da França

${ }^{20}$ Agradeço vivamente a Pierre Manent por ter sugerido, no "comité de suivi de thèse" realizado em junho de 2018, na EHESS, essa consideração do problema do arbítrio no quadro mais geral do governo representativo segundo os modernos, antes de tratar o problema, de modo mais específico, na obra de Constant. A Seção 1.1 deste capítulo responde em grande parte a essa sugestão de Manent. 
termidoriana - os quais se tornarão os interlocutores principais de Constant durante o Diretório, como veremos nas seções seguintes. Roederer e Lezay-Marnésia podem ser interpretados como os principais difusores de uma reformulação da cultura política revolucionária que ganha corpo a partir do 9 Termidor, contestando o legicentrismo rigoroso dos anos iniciais da Revolução e clamando pelo fortalecimento e pela independência de um Poder Executivo concebido como protetor da ordem. A influência que esses autores tiveram sobre o golpe do 18 Brumário e sobre a construção do regime autoritário que se seguiu a ele levou estudiosos como Andrew Jainchill a os compreender pelo rótulo de "autoritarismo liberal" (JAINCHILL, 2008, Cap. 5). Esta tese propõe a substituição da expressão "autoritarismo liberal" por "liberalismo da ordem", uma vez que esta última expressão coloca menos ênfase no resultado histórico das posições de Roederer e Lezay-Marnésia (o autoritarismo napoleônico, não premeditado desde os primeiros escritos desses autores), e mais ênfase em seu ponto de partida: o restabelecimento da ordem por meio de um Poder Executivo forte, eficaz e independente. Esse empoderamento do Executivo não era pensado, ao menos de início, em termos explicitamente autoritários. Pelo contrário, os autores em questão rejeitavam todo apelo ao despotismo ou à tirania. O ponto a ser destacado pela Seção 1.2 é que essa corrente de pensamento podia pender para o autoritarismo justamente por não assumir em toda a sua dimensão o problema do arbítrio, supondo que a outorga de poderes discricionários ao Executivo não implicava a formulação do problema de como evitar a degeneração da discricionariedade em tirania. A fim de compreender essa obliteração do problema do arbítrio, a Seção 1.2 analisa o sistema de harmonia entre os poderes defendido por Jacques Necker em 1792 - lido aqui como a inspiração principal do liberalismo da ordem que ganha força a partir do 9 Termidor -, assim como as repercussões desse sistema na maneira como Roederer e Lezay-Marnésia compreendem o papel do Executivo no contexto termidoriano. A leitura que esses autores fazem das etapas da Revolução Francesa, em sintonia com sua teoria das paixões revolucionárias e da opinião pública, coroa um sistema de pensamento que contorna o problema do arbítrio sob o mantra de que a Revolução já terminou.

A seção 1.3 procura compreender a emergência do problema do arbítrio nos primeiros escritos do jovem Constant sob o Diretório, situando esses escritos no diálogo crítico com Roederer e Lezay-Marnésia - autores que frequentavam o mesmo círculo pessoal (notadamente o salão de Madame de Staël) e compartilhavam o projeto político 
de concluir a Revolução Francesa por um justo meio que recusava igualmente seus excessos e qualquer passo retrógrado, mas que haviam obliterado o problema do arbítrio por meio de sua teoria das instituições políticas e das fases da Revolução Francesa. Contra esses autores de seu entourage, Constant se destaca por uma teoria das reações políticas, a qual nega que a Revolução já tenha terminado e levanta o problema das medidas arbitrárias possivelmente exigidas para enfrentar o espírito de reação. $\mathrm{O}$ arbítrio se torna um problema agudo por causa da tensão entre o princípio da soberania do povo e o imperativo de manter o governo republicano independente da maioria nacional em um contexto de reação política. Entretanto, o autor responde a esse problema com a rejeição absoluta do arbítrio, a qual forma um equilíbrio tenso com o princípio da soberania do povo e a independência do governo republicano em relação à maioria nacional.

Por fim, a Seção 1.4 procura compreender a controvérsia entre Constant e LezayMarnésia a respeito da interpretação do Terror, na primavera de 1797, à luz desses encaminhamentos diferentes que Constant e o liberalismo da ordem davam ao problema do arbítrio. Embora esse debate já tenha recebido certa atenção (FURET, 1983; FURET, 1989; RAYNAUD, 1988; GAUCHET, 1989; BARBERIS, 1998a; FLORENZANO, 2001; BURNAND, 2010), acreditamos que ele ganha uma nova luz com nossa proposta de situá-lo perante uma divergência mais ampla sobre a conclusão da Revolução Francesa e sobre a possibilidade do arbítrio no momento pós-termidoriano. Com efeito, se LezayMarnésia chega a justificar o Terror de 1793-1794 como uma etapa necessária da Revolução, seu móbil principal não é a demonstração de Realpolitik, como querem alguns comentadores (GAUCHET, 1989, p. 163; BARBERIS, 1998a, p. 510), mas antes sua crença de que a derrubada de Robespierre concluiu a Revolução e abriu um tempo histórico qualitativamente distinto no qual o arbítrio seria deslocado, de modo que a justificação do arbítrio empregado antes do 9 Termidor não poderia servir de pretexto para o emprego anacrônico do arbítrio no momento pós-termidoriano. No caso de Constant, é seu diagnóstico segundo o qual a Revolução ainda precisa enfrentar o espírito de reação que o leva a condenar categoricamente o Terror de 1793-1794, pois a justificação do arbítrio empregado nessa época poderia autorizar o emprego do arbítrio em 1797. Não obstante, como já se depreende da seção anterior, essa condenação categórica do arbítrio, por parte de Constant, não era desprovida de tensões, dado o imperativo de manter o governo republicano ao mesmo tempo fiel ao princípio da soberania do povo e independente em relação à maioria nacional. Assim, o capítulo 
termina sublinhando a precariedade do equilíbrio teórico-político construído por Constant em seus escritos do Primeiro Diretório, o qual será posto à prova pelo golpe do 18 Frutidor.

\subsection{O problema do arbítrio, de Locke à Revolução Francesa}

A incorporação política do arbítrio tem uma história que precede em muito os escritos de Constant, confundindo-se, em parte, com a trajetória do próprio pensamento político ocidental. Se associarmos o problema do arbítrio ao da decisão impossível de teorizar completamente ou de remeter a princípios fixos, como o faz Constant em Des réactions politiques (cf. p. 21 supra), uma primeira maneira de incorporar positivamente o arbítrio pode ser encontrada na discussão de Aristóteles sobre a prudência (phronêsis), entendida como a virtude necessária para orientar a ação com vistas a um "bem factível”, em um mundo contingente e incerto, no qual a prática não pode ser inteiramente determinada pela teoria (AUBENQUE, 1997). Como sugere Jaume, Constant se filia em várias de suas reflexões a essa filosofia aristotélica da necessidade da prudência na política, "questão de discernimento, de julgamento prático, de tratamento do caso particular na ausência de lei universal” (JAUME, 2001, p. 424).

Se associarmos o problema do arbítrio à questão, mais específica, das medidas extraordinárias e extralegais empregadas para salvar uma ordem política em perigo, a discussão remonta igualmente à Antiguidade clássica, particularmente à instituição romana da ditadura. Ao prever constitucionalmente a elevação de uma autoridade absoluta e centralizada que, no prazo máximo de seis meses, seria encarregada de empregar todos os meios à sua disposição para conjurar um perigo que estivesse ameaçando a República, os romanos legaram para o pensamento político ocidental um paradigma extremamente influente do estado de exceção. Nesse paradigma, a suspensão temporária das leis e a elevação de uma autoridade discricionária e potencialmente ilimitada se colocam a serviço das próprias leis, na medida em que as medidas extraordinárias necessárias para afastar o perigo que ameaça a ordem política podem ser empregadas observando-se um caminho traçado pela própria Constituição, sem haver, portanto, a necessidade de transgredi-la. 
Se passarmos da Antiguidade à modernidade, notamos a afirmação daquilo que está sendo aqui chamado de arbítrio no coração do processo histórico de construção dos modernos Estados nacionais. Segundo Lynch (2020, no prelo), a "revolução monárquica" que, do final da Idade Média até o século XVII, concentrou o poder nas mãos dos monarcas dos emergentes Estados nacionais da Europa Ocidental, em detrimento dos poderes da Igreja, da nobreza feudal, das cidades e das corporações, foi legitimada pelas teorias da razão de Estado e da soberania absoluta, formuladas ao longo dos séculos XVI e XVII. Em ambas as modalidades de teoria, o arbítrio, ou a faculdade de tomar decisões que não decorrem de um aparato legal existente, podendo contrariar esse aparato, é afirmado como um atributo indispensável da vontade do Rei, sem o qual o Estado entraria em colapso. Nas teorias da razão de Estado, o arbítrio monárquico é justificado pelas situações excepcionais de perigo que requerem do príncipe uma ação rápida e liberada dos constrangimentos morais e legais vigentes nos períodos ordinários, com vistas à salvação do Estado. Trata-se de outro paradigma do estado de exceção, diferente do da ditadura romana, posto, desta vez, a serviço da construção da autoridade monárquica. Por sua vez, as teorias da soberania, as quais atingem seu apogeu com Jean Bodin e Thomas Hobbes, fazem do arbítrio o modus operandi normal do chefe do Estado, eclipsando a distinção entre períodos ordinários regidos pelas leis e momentos extraordinários governados pelo arbítrio (KERVÉGAN, 2005, p. 252). Na filosofia política de Hobbes, a lei não é outra coisa senão a ordem do soberano, e essa ordem deve emanar de uma vontade que, para ser efetiva, não pode ser limitada por nenhuma lei, costume ou preceito moral prévio (HOBBES, 2003, Cap. XXVI). É a afirmação plena do arbítrio como fundamento da autoridade e da ordem política. ${ }^{21}$

De acordo com Lynch (2020, no prelo), a "revolução monárquica" do início da Idade Moderna é seguida por uma "revolução oligárquica" que, nos séculos XVII e XVIII, passa a contestar a pretensão dos monarcas europeus à soberania absoluta, exigindo uma ordem política compatível com a liberdade e com a participação da sociedade civil ou burguesa em ascensão. Principalmente na Inglaterra do século XVII, imersa em um violento e conturbado processo revolucionário, e na França do século XVIII, onde se consolida o movimento intelectual do Iluminismo, diversos autores se opõem ao arbítrio

${ }^{21}$ Segundo David Runciman (2020), uma das grandes lições de Hobbes, ainda válida atualmente, é que "não há como evitar o elemento de arbítrio no coração de toda política. Trata-se do arbítrio do julgamento político individual". 
reivindicado como legítimo pelos reis e seus porta-vozes intelectuais. Nessa luta intelectual contra o absolutismo monárquico, ganha força um ideal de império da lei que faz do Poder Legislativo, concebido como independente do Rei, o poder central e soberano, ao qual deveria se subordinar o Poder Executivo exercido pelo monarca. $\mathrm{O}$ Segundo Tratado sobre o Governo de John Locke, de 1689, estabelece esse ideal de modo cristalino: "o legislativo é o poder supremo (...), e todos os demais poderes depositados em quaisquer membros ou partes da sociedade devem derivar dele ou ser-lhe subordinados" (LOCKE, 2005, p. 519, §150; ênfases do autor). Essa afirmação da soberania (ou, na linguagem lockeana, supremacia) do Legislativo constitui um golpe mortal sobre as pretensões monárquicas a um arbítrio legítimo. Embora, na teoria de Locke, o Rei deva ser obedecido na qualidade de executor supremo da lei, essa obediência deve ser fundada na subordinação estrita do príncipe à lei e ao poder encarregado de a proclamar:

(...) não tem ele nenhuma vontade ou poder a não ser o da lei. Quando, porém, deixa essa representação, essa vontade pública, e passa a agir segundo sua própria vontade particular, degrada-se e não é mais que uma pessoa particular sem poder e sem vontade, sem direito algum à obediência, pois que não devem os membros obediência senão à vontade pública da sociedade (LOCKE, 2005, p. 520, §151).

O ideal de império da lei e de soberania do Legislativo vocalizado por Locke (entre outros) se mostraria extremamente influente nos séculos seguintes, servindo de bandeira, no final do século XVIII, às revoluções americana e francesa. Especialmente na Revolução Francesa, em que o acerto de contas com a soberania monárquica era uma questão mais explícita do que na Revolução Americana, o ideal de império da lei e de um Rei subordinado ao Poder Legislativo eleito pelo povo se constitui como a fórmula que deveria pôr um fim definitivo aos séculos de arbítrio monárquico. No entanto, a ideia de um monarca subordinado ao Poder Legislativo não abole completamente aquilo que estamos chamando na tese de "problema do arbítrio", como se depreende do próprio Segundo Tratado sobre o Governo. Ao tratar a prerrogativa monárquica no Capítulo XIV do Segundo Tratado, Locke opera uma incorporação controlada do arbítrio no interior do próprio quadro do império da lei e da subordinação do Executivo ao Legislativo. Desse modo, ele demonstra ser possível articular um "decisionismo moderado" em uma teoria política preocupada em evitar a submissão do indivíduo à vontade arbitrária de outrem.

A questão da margem de ação discricionária a ser concedida ao Poder Executivo se coloca a Locke porque, apesar de sua necessária subordinação ao Legislativo, este é 
um poder intermitente, ao passo que aquele é permanente: "Não é necessário, nem tão conveniente, que o legislativo esteja sempre em função. Mas é absolutamente necessário que o poder executivo esteja, pois, se nem sempre é preciso elaborar novas leis, sempre há necessidade de execução das leis já elaboradas" (LOCKE, 2005, p. 521, §153; ênfases do autor). Assim, o Poder Executivo pode se deparar com situações não previstas pelo Legislativo, precisando agir antes que este último seja convocado e elabore novas leis. $\mathrm{O}$ filósofo não hesita em chamar essa ação do Poder Executivo não regulada pelas leis de discricionária, justificando essa discricionariedade pela impossibilidade de que as leis prevejam tudo: "Muitas questões há que a lei não pode em absoluto prover e que devem ser deixadas à discrição daquele que tenha nas mãos o poder executivo, para serem por ele reguladas, conforme o exijam o bem e a vantagem do público" (LOCKE, 2005, p. $529, \S 159)$.

Na realidade, Locke vai além dessa simples constatação de que o Poder Executivo precisa por vezes agir no silêncio da lei, chegando a afirmar que há situações em que o governante precisa agir em um sentido contrário ao estipulado pelas leis, "visto que muitos acidentes podem ocorrer em situações em que a observância estrita e rígida das leis pode causar danos (como não demolir a casa de um homem inocente para deter um incêndio quando a casa vizinha esteja em chamas)" (LOCKE, 2005, p. 529, §159). É assim que o autor introduz seu conceito de prerrogativa, definido como "esse poder de agir conforme a discrição em prol do bem público, sem a prescrição da lei e por vezes até contra ela" (LOCKE, 2005, p. 530, §160).

Manent percebe na discussão de Locke sobre a prerrogativa a atribuição ao Poder Executivo de "uma consistência e uma importância de fato às quais não corresponde, em sua doutrina, uma igual dignidade de direito" (MANENT, 2012, p. 111; ênfases do autor). Residiria aí todo o "problema do Executivo moderno" (MANENT, 2012, p. 111): embora o Executivo não possa reivindicar a legitimidade possuída pelo Legislativo e atrelada à representação da sociedade, ele se fortalece na medida em que "encarna a 'transcendência' do poder político em relação à sociedade” (MANENT, 2012, p. 115). Vale notar o paralelo entre a interpretação de Manent sobre o Poder Executivo lockeano e a interpretação de Gauchet sobre o poder neutro de Constant, a ser explorada no Capítulo 2 desta tese: em ambos os casos, trata-se de encarnar em um poder de Estado a irredutibilidade do político em relação à representação da pluralidade de interesses 
sociais. E, em ambos os casos, o poder em questão é imbuído de uma ação discricionária que escapa ao controle de uma concepção estrita de império da lei.

A admissão de uma ação discricionária do governo, a qual pode até mesmo contrariar as leis existentes quando sua execução literal pode causar danos à comunidade política, em uma filosofia política que estabelece o império da lei e a subordinação do Executivo ao Legislativo, permite situar Locke na categoria de "decisionismo moderado", proposta por esta tese para o caso de Constant. Com efeito, o problema de como incorporar o inevitável arbítrio ao sistema político, impedindo ao mesmo tempo sua degeneração em tirania, encontra-se formulado de modo cristalino no Segundo Tratado sobre o Governo. Pode-se mesmo afirmar que esse tema já foi muito mais estudado na obra de Locke do que na de Constant (DUNN, 1969, Caps. 11-12; PASQUINO, 1998; FATOVIC, 2004; CASSON, 2008). Cabe apontar brevemente aqui alguns problemas levantados pela noção lockeana de prerrogativa, na medida em que esses problemas são intrínsecos à questão de como incorporar o arbítrio ao sistema político, impedindo ao mesmo tempo sua deriva tirânica. Esses problemas não deixarão de aparecer na obra de Constant, embora este tenha articulado a incorporação política do arbítrio de modo diferente de Locke, a fim justamente de evitar algumas das aporias em que cai o filósofo inglês.

O primeiro problema que salta aos olhos é justamente o de como distinguir a prerrogativa legítima do arbítrio tirânico, ou seja, da decisão discricionária que dispensa os súditos da obediência, na medida em que o Rei se torna "uma pessoa particular sem poder e sem vontade" (LOCKE, 2005, p. 520, §151), não se apoiando mais sobre a autoridade impessoal da lei. Como muitos comentadores já sublinharam (PASQUINO, 1998, p. 201-201; FATOVIC, 2004, p. 279), o que permite a Locke fazer essa distinção é a introdução de outro critério de legitimidade política situado acima do império da lei: trata-se da adesão à máxima ciceroniana Salus populi suprema lex ("A salvação do povo é a suprema lei"), mencionada no parágrafo 158 do Segundo Tratado: "Salus Populi suprema lex é, com certeza, uma regra tão justa e fundamental que aquele que a segue com sinceridade não pode errar perigosamente" (LOCKE, 2005, p. 526-527, §158). Como esclarece John Dunn (1969, p. 163-164), o filósofo inglês estava se apoiando em uma máxima que teóricos da razão de Estado, como Gabriel Naudé (lido e anotado por Locke em um período próximo ao da redação dos Dois tratados sobre o governo), haviam mobilizado para justificar qualquer ação maléfica que resultasse em algum bem para o 
povo, porém, na versão lockeana, a máxima só seria capaz de justificar atos ilegais ou inconstitucionais, jamais imorais. Isso significa que uma ação do Poder Executivo que não decorre da lei ou mesmo a contraria é legítima se ela segue os princípios da moralidade e visa ao bem público, ao passo que ela é ilegítima se ela objetiva a opressão da comunidade política e subverte os fins de sua instituição.

Essa consideração do bem público como o critério último da legitimidade de uma ação discricionária do governo pode ser vista como constituindo ao mesmo tempo a força e a fraqueza do raciocínio de Locke. Comentadores recentes (PASQUINO, 1998; FATOVIC, 2004; CASSON, 2008) sublinham que, no capítulo sobre a prerrogativa, o filósofo inglês se revela um autor preocupado com valores substantivos (notadamente o bem da comunidade) e consciente do papel indispensável do julgamento humano para a realização desses valores, em um mundo dominado pela contingência e pelas circunstâncias imprevisíveis. Desse modo, ele não pode ser encaixado no liberalismo formalista, racionalista e estritamente legalista que Carl Schmitt lhe atribui em Teologia Política (SCHMITT, 2005, p. 13-14). Se a elevação do bem público ao papel de critério último da legitimidade política pode, assim, ser considerada como uma força de Locke em relação ao liberalismo formalista, racionalista e estritamente legalista que se desenha no final do século XVIII, o caráter vago da noção de bem público e sua capacidade de ser apropriada por qualquer um constitui sua fraqueza. ${ }^{22}$ De fato, o critério do bem público não responde verdadeiramente à questão de como distinguir a prerrogativa legítima do arbítrio tirânico, mas desloca a questão para como determinar o juiz último do que constitui o bem público e quais ações são autorizadas em seu nome.

A resposta de Locke é conhecida: o juiz último do bem público e das ações autorizadas em seu nome é o povo. O povo, diz o filósofo, aprovou com razão a expansão da prerrogativa dos bons e sábios reis da história da Inglaterra, pois ele via que, mesmo quando esses monarcas contrariavam as leis, eles "agiam conforme ao fundamento e ao fim de todas as leis, o bem público" (LOCKE, 2005, p. 533, §165). E quando tiranos se apropriam da prerrogativa que os bons príncipes utilizavam para fazer o bem, a fim de oprimir o povo? A resposta do autor é igualmente clara:

${ }^{22}$ Veremos, na Seção 1.3, Constant sustentar a superioridade das formas legais em relação aos valores substantivos, por causa justamente da possibilidade de apropriação desses valores substantivos por tiranos. Ele tem em mente a experiência do Terror. 
(...) entre um poder executivo em função com uma tal prerrogativa e um legislativo que dependa da vontade desse poder para sua reunião, não pode haver juiz sobre a Terra (...). Nesses casos e em todos aqueles em que não há juiz sobre a Terra, não tem o povo outro remédio além do apelo aos céus (LOCKE, 2005, p. 535, §168; ênfases do autor).

Como afirma Casson (2008, p. 960), "não é por acidente que Locke introduz sua teoria do direito de revolução pela primeira vez em sua seção sobre a prerrogativa". O julgamento do povo (que Locke considera como capaz de deliberar e agir como corpo unitário e racional independentemente da autoridade política, ao contrário de Hobbes) aparece como o critério capaz de atribuir ao bem público um sentido concreto e tangível. A ação extralegal do povo (a revolução), por sua vez, aparece como o único modo de impedir a ação extralegal do governo de degenerar em tirania, dado que a natureza extralegal da prerrogativa descarta logicamente qualquer outra forma de julgamento. Novamente, reside aí tanto a força como a fraqueza do argumento de Locke. Por um lado, a teoria do filósofo permanece atual, na medida em que ela sublinha que a liberdade política não pode ser garantida somente por instituições fixas e pela estrita observação formalista das leis, exigindo um povo ativo e mobilizado que fiscaliza seus governantes e ameaça derrubá-los se eles se comportam tiranicamente (CASSON, 2008). Por outro lado, a revolução, considerada como a única precaução contra um poder discricionário potencialmente absoluto (uma vez que o Poder Executivo é subordinado às leis, mas pode transgredi-las a todo momento sob o pretexto da realização do bem público), pode ser vista como uma resposta frágil ao problema do arbítrio em política. Em primeiro lugar, pela dificuldade de fazer uma revolução, a qual é admitida pelo próprio Locke, para quem o povo só se revolta nos casos extremos e após grandes vexações. Em segundo lugar, pelo caráter extremo e perigoso do próprio remédio, o qual pode instituir governantes tão tirânicos quanto os derrubados, por vezes até mais.

Assim, Locke é um dos primeiros filósofos políticos a articular conscientemente um "decisionismo moderado" no interior do quadro do império da lei e da subordinação do Poder Executivo ao Legislativo. Porém, a aporia em que ele cai ao tentar determinar a maneira de impedir a degeneração da prerrogativa em tirania tornava seu modo de incorporar controladamente o arbítrio ao sistema político pouco atraente na época em que escreve Constant, obcecada com a necessidade de terminar a Revolução Francesa. Em um círculo político que buscava mecanismos legais e institucionais de moderar o poder, de modo a evitar novas revoluções, a elevação da revolução a garantia principal contra a tirania não tinha como se tornar a resposta ao problema do arbítrio. 
No século XVIII, Jean-Jacques Rousseau radicaliza a subordinação do Poder Executivo ao Legislativo já estabelecida por Locke. N'O contrato social, de 1762, assim como no Segundo Tratado sobre o Governo, o ideal de império da lei e de supremacia do Legislativo sobre os demais poderes é a pedra angular de um contrato social que tem por objetivo último garantir que ninguém seja submetido à vontade arbitrária de outrem. Em ambos os contratos sociais, a lei civil cumpre o objetivo de superar a insuficiência da lei de natureza para regrar as controvérsias humanas. Todavia, Rousseau vai além de Locke na elevação da lei a critério último da legitimidade política. Para o filósofo genebrino, a lei é o ato pelo qual o povo estatui sobre si mesmo. Logo, ela é uma expressão da vontade geral - a única vontade que pode legitimamente mover o corpo político formado pelo contrato social. Quando o corpo político efetua um movimento que não é estritamente guiado pela vontade geral, expressa por todo o povo sob a forma da lei, ele sai da legitimidade e entra em estado de dissolução.

É sob esse ângulo que Rousseau examina a questão do governo, ou do Poder Executivo. Ao contrário de Locke, não é cabível, para o autor d'O contrato social, considerar o príncipe como um guardião do bem público, cujas ações devem ser julgadas segundo o critério de sua conformidade ou não a esse bem comum. De acordo com a metáfora corporal cara a Rousseau, o Poder Legislativo é a vontade, ao passo que o Poder Executivo é a força do corpo político (ROUSSEAU, 2006, Livro III, Cap. I). Portanto, o que define o emprego legítimo dessa força não é simplesmente a perseguição do bem público, mas seu acordo com a vontade do corpo político, ou seja, com a lei. Logo, não pode haver, para Rousseau, uma ação legítima do governo que não seja uma estrita aplicação da lei geral aos casos particulares. Não há lugar para a prerrogativa régia, tal como concebida por Locke. Uma simples decisão discricionária do governo se torna, nessa teoria, um ato de tirania que dissolve o corpo político e destrói a liberdade, submetendo cada cidadão à vontade arbitrária de outrem.

O interessante é que, mesmo divergindo de Locke sobre a legitimidade de uma decisão governamental independente da lei, Rousseau considerou, em sua reflexão política, o problema que havia conduzido o filósofo inglês ao conceito de prerrogativa. Esse problema é o da impossibilidade de que as leis prevejam tudo, o que coloca a necessidade de decisões rápidas perante circunstâncias imprevistas e perigosas:

A inflexibilidade das leis, que as impede de se adaptar aos acontecimentos, pode, em certos casos, torná-las perniciosas e causar por seu intermédio a perda do Estado em crise. A ordem e a lentidão das formas requerem um lapso de 
tempo que as circunstâncias algumas vezes recusam. Podem apresentar-se mil casos não previstos pelo legislador, e é uma previdência muito necessária saber que não se pode prever tudo (ROUSSEAU, 2006, Livro IV, Cap. VI, p. 149).

Esse problema não conduz Rousseau à prerrogativa lockeana, mas antes a um resgate da instituição romana da ditadura. Essa instituição já havia sido resgatada por Nicolau Maquiavel (MAQUIAVEL, 2007, Livro I, Caps. 34-35), de quem o filósofo genebrino é tributário, mas este último inova ao transpor essa instituição romana para uma teoria contratualista da soberania popular. Trata-se de uma resposta muito diferente da de Locke ao problema da insuficiência das leis. Para o autor inglês, a prerrogativa não constitui uma suspensão temporária da ordem política normal, mas um poder que o monarca sempre possui de avaliar se a realização do bem público não exige medidas diferentes das prescritas pela lei. O que justifica a maior ou menor extensão da prerrogativa não são nem mesmo as circunstâncias específicas, mas antes a bondade ou maldade do príncipe. Rousseau, ao contrário, sublinha a ditadura como uma suspensão das instituições políticas regulares, a qual deve ser bem marcada no tempo e separada cuidadosamente da ordem política normal. Trata-se de um resgate da noção de estado de exceção, a qual havia sido marginalizada pela normalização do arbítrio operada pelas teorias da soberania. N'O contrato social, o estado de exceção volta a ser a morada legítima do arbítrio. Nas circunstâncias perigosas, em que as leis passam de vetores da liberdade a obstáculos, é preciso que se nomeie "um chefe supremo que faça calar todas as leis e suspenda por um momento a autoridade soberana" (ROUSSEAU, 2006, Livro IV, Cap. VI, p. 150). Com a ressalva importante de que "a suspensão da autoridade legislativa não significa a sua abolição: o magistrado que a silencia não pode fazê-la falar, domina-a sem poder representá-la e tudo pode fazer, exceto ditar leis" (ROUSSEAU, 2006, Livro IV, Cap. VI, p. 150).

Ao fazer da ditadura a única situação em que o arbítrio, entendido no sentido de decisão discricionária não pautada pela lei, é legítimo, ${ }^{23}$ Rousseau aloca no estado de

${ }^{23}$ Em uma interessante tese sobre a prerrogativa do Poder Executivo nas obras de Locke e Rousseau, Benjamin J. Gutierrez argumenta que o elogio de Rousseau, nas Considerações sobre o governo da Polônia, de 1771, ao papel das confederações para afastar a anarquia na Polônia revela uma admissão surpreendente, por parte do filósofo genebrino, de medidas extraconstitucionais de um Poder Executivo interino (GUTIERREZ, 2011, p. 37-41). Embora o ponto seja relevante, é preciso lembrar que Rousseau compreende o papel das confederações polonesas pela chave conceitual da ditadura romana: "A Confederação é, na Polônia, o que era a Ditadura entre os romanos. Tanto uma como a outra fazem as leis se calar perante um perigo urgente" (ROUSSEAU, 1964, p. 998). Portanto, as Considerações sobre o 
exceção tudo aquilo que não pode ser admitido no estado normal do corpo político, mas também não pode ser descartado de uma maneira absoluta, uma vez que as leis não têm a capacidade de prever todas as circunstâncias perigosas suscetíveis de emergir. Trata-se de uma concepção do estado de exceção completamente diferente da de Schmitt, para quem a exceção revela o verdadeiro soberano. Para Rousseau, o estado de exceção não revela o soberano, mas apenas o suspende por um breve momento. O ditador tem o poder de calar temporariamente o soberano, mas jamais o de instituir ele próprio atos de soberania. Se a ditadura revela algo sobre o estado normal do corpo político, é apenas a ilegitimidade, nesse estado normal, de qualquer medida discricionária do governo - razão pelo qual o uso discricionário do poder precisa ser circunscrito em uma situação excepcional com prazo delimitado.

Seguindo Maquiavel, o autor d'O contrato social considera a duração curta e não prorrogável da ditadura como a principal garantia contra sua transformação em tirania (MAQUIAVEL, 2007, Livro I, Caps. 34-35; ROUSSEAU, 2006, Livro IV, Cap. VI, p. 152). Na perspectiva republicana de Maquiavel e Rousseau, se há circunstâncias que reclamam o arbítrio por não serem previstas pelas leis ou se adaptarem mal a suas formas lentas, a boa Constituição é aquela que regula essa discricionariedade necessária, determinando os casos em que ela pode ter lugar, durante quanto tempo e de que forma. É o que o filósofo genebrino preconiza a respeito das confederações na Polônia, consideradas por ele como um equivalente da ditadura romana:

É preciso deixá-las, mas deve-se regrá-las. (...) Assim, em vez de abolir as confederações, determinem os casos em que elas podem legitimamente ter lugar, e depois regrem bem sua forma e seu efeito, para lhes conferir uma sanção legal tanto quanto é possível sem prejudicar sua formação nem sua atividade (ROUSSEAU, 1964, p. 999).

O raciocínio de Rousseau, semelhante nessa questão ao de Maquiavel, é que a Constituição deve prever e regular os casos extraordinários que exigem um uso discricionário do poder, para que o advento dessas circunstâncias excepcionais não implique a violação da Constituição. Isso não impede que, na situação normal, a lei seja

governo da Polônia não introduzem uma nova compreensão das medidas discricionárias e extralegais do governo, diferente em relação à apresentada n'O contrato social. As Considerações aplicam o paradigma da ditadura romana, tratado no Capítulo VI do Livro IV d'O contrato social, ao contexto polonês. A legitimidade do arbítrio e da decisão discricionária permanece circunscrita ao estado de exceção. 
o único critério de legitimidade de uma decisão política, o governo não podendo formular nenhuma vontade que não seja idêntica à da lei.

Na Revolução Francesa, o ideal de império da lei vocalizado por autores como Locke e Rousseau (entre outros) irrompe no embate entre a Assembleia Nacional Constituinte e o Rei. Como na teoria desses dois filósofos, o ideal de império da lei acaba se traduzindo institucionalmente na subordinação dos poderes Executivo e Judiciário ao Legislativo. Esse modo de compreender o império da lei se consolida nos debates de agosto e setembro de 1789 sobre o veto monárquico, os quais tinham por objeto o lugar do Rei na nova ordem política que estava sendo projetada pela Constituinte. Até esse momento, o chamado "partido monarquiano", agrupado na Sociedade dos Amigos da Constituição Monárquica (Malouet, Mounier, Lally-Tollendal, Clermont-Tonnerre, entre outros), nutria a esperança de transpor para a nova Constituição uma Coroa forte, encarregada de representar a Nação e defender o interesse público contra os excessos e facciosismos do Legislativo, temperando, ao mesmo tempo, a força do trono por meio de um sistema de equilíbrio dos poderes inspirado na leitura de Montesquieu sobre o modelo inglês (LYNCH, 2007, p. 53-67). Em setembro de 1789, a derrota do projeto monarquiano (rejeição do bicameralismo e admissão de um veto monárquico apenas suspensivo) representou "uma derrubada simbólica e prática do trono" (FURET; HALÉVI, 1996, p. 182), em decorrência da qual o Rei passou a ser considerado como um delegado da Assembleia, designado como o "primeiro funcionário do reino" (FURET; HALÉVI, 1996, p. 182). Esse novo lugar da realeza estava de acordo com a concepção rousseauniana de um Poder Executivo sem vontade própria, limitado à execução da vontade expressa pelo Legislativo. Emmanuel-Joseph Sieyès procura conciliar a teoria de Rousseau com uma concepção absoluta da representação segundo a qual a Assembleia encarnaria a Nação, no que é derrotado por uma corrente alternativa que, a fim de conciliar a tensão rousseauniana entre a soberania do povo e a representação, propõe o veto monárquico suspensivo como uma forma de enviar certas decisões do Legislativo para a apreciação do povo soberano (BAKER, 1990, p. 252-305). De todo modo, esse veto suspensivo durante duas legislaturas (com a derrota do Rei no caso em que a lei vetada é votada por uma terceira legislatura) não era compreendido como um direito de decisão próprio ao monarca, mas antes como um modo de remeter as decisões mais polêmicas da Assembleia para a posterior apreciação do povo. O Poder Executivo se torna 
desprovido de qualquer margem de decisão discricionária, em um cenário bastante diferente do da prerrogativa lockeana.

Isso não significa que os constituintes franceses tenham ignorado as situações de perigo que exigem uma flexibilização das leis. Como Rousseau, eles pensam o arbítrio necessário para enfrentar as circunstâncias perigosas pelo paradigma do estado de exceção. Como afirma Patrice Gueniffey, "a Constituição de 3 de setembro de 1791 é longe de ser silenciosa sobre o capítulo da exceção" (GUENIFFEY, 2000, p. 164). Ela não prevê a convocação de um ditador, nos moldes da Roma antiga, mas sim a suspensão de direitos individuais fundamentais em casos de perigo para o corpo político. Votada em 21 de outubro de 1789, a lei marcial prevê situações em que o exército deve dissipar pela força qualquer agrupamento para proteger a segurança do Estado, contrariando o princípio, válido em circunstâncias ordinárias, da liberdade de associação. Criada em 10 de maio de 1791, a Alta Corte Nacional ("Haute Cour nationale") é encarregada de julgar os suspeitos de atentar ou conspirar contra a segurança do Estado ou a Constituição, prevendo situações excepcionais em que o princípio do juiz natural pode ser suspenso. $\mathrm{O}$ raciocínio dos constituintes é semelhante ao de Maquiavel e Rousseau ${ }^{24}$ a respeito da ditadura: se há circunstâncias perigosas que não podem ser combatidas pela simples aplicação das leis, requerendo um uso discricionário do poder que contraria os princípios válidos para os tempos ordinários, cabe à Constituição enquadrar e regular as situações em que esse arbítrio temporário é necessário, a fim de que ele não se realize como uma violação da Constituição. Assim, "a Constituição de 1791 não desconhece as exigências

${ }^{24}$ Segundo Gueniffey (2000, p. 171, nota 21), os revolucionários franceses se valiam menos de Rousseau do que de Montesquieu para justificar as leis de exceção. No Capítulo XIX do Livro XII de $O$ espírito das leis ("Como se suspende o uso da liberdade na república”), lê-se que "há, nos Estados em que se faz mais caso da liberdade, leis que a violam contra um só, para preservá-la para todos" (MONTESQUIEU, 2005, Livro XII, Cap. XIX, p. 212), e que "existem casos em que se deve colocar um véu sobre a liberdade, como se escondem as estátuas dos deuses” (MONTESQUIEU, 2005, Livro XII, Cap. XIX, p. 213). Como Locke, Montesquieu endossa a máxima ciceroniana segundo a qual "a salvação do povo é a lei suprema” (MONTESQUIEU, 2005, Livro XXVI, Cap. XXIII, p. 522), de modo que as leis existentes em um Estado podem ser contornadas quando ferem essa máxima. Segundo Gueniffey (2000, p. 169-170), Montesquieu apenas ilustra uma máxima comum nas teorias contratualistas, segundo as quais, no estado civil, a liberdade individual depende da liberdade coletiva, podendo ser suspensa quando a coletividade se julga diante de um perigo que ameaça sua própria existência. 
da 'segurança pública' (...), mas ela as enquadra de modo bastante estrito” (GUENIFFEY, 2000, p. 167).

Embora a Constituição de 1791 dotasse o Estado de um arsenal poderoso de leis de exceção disponíveis para impor a ordem, esse arsenal era insuficiente para a realização dos objetivos políticos, cada vez mais radicais, dos revolucionários. Em sua guerra contra os emigrados e os clérigos refratários, a Constituinte, e depois a Assembleia Nacional Legislativa, adotaram, a partir de julho de 1791, medidas repressivas contra esses dois alvos que extravasavam o domínio das modalidades de estado de exceção previstas na Constituição. Isso porque as leis excepcionais previstas pela Constituição deveriam suspender certos direitos individuais perante atos de hostilidade definidos pela lei, ao passo que as medidas repressivas contra emigrados e clérigos refratários tinham por alvo grupos específicos da população, independentemente dos atos hostis que estes viessem a cometer (GUENIFFEY, 2000, p. 166-167). No fundo, era outra concepção de estado de exceção que começava a se impor com a radicalização da Revolução. Para usar os termos de Schmitt, no clássico A Ditadura, de 1921, passava-se da "ditadura comissarial" de Rousseau e da tradição republicana (uma suspensão temporária das leis, com o objetivo da preservação da Constituição existente, a qual regula a forma de advento dessa ditadura e sua duração) à “ditadura soberana”, a qual não é regulada por nenhuma Constituição, pois seu ponto de referência é uma ordem constitucional ainda não instituída. O conceito invocado para legitimar uma ditadura soberana é o de Poder Constituinte, o qual permite a essa ditadura querer sem limites, revogando as leis existentes e instituindo novas segundo a sua vontade. Sobre o Poder Constituinte, Schmitt diz ser "uma ideia que, em sua substância, é uma consequência d'O contrato social de Rousseau, embora ele não a designe como um poder separado" (SCHMITT, 2014, p. 111). A história da Revolução Francesa, de 1789 a 1794, pode ser lida à luz do fracasso de realizar a revolução e regrar os conflitos abertos por ela com os simples instrumentos da "ditadura comissarial", o que levou à ascensão de grupos políticos cada vez mais radicais que fizeram um uso crescente da retórica e dos meios da "ditadura soberana".

Embora essa guinada seja identificada por Gueniffey já em julho de 1791, ela fica mais clara com as consequências da Revolução de 10 de agosto de 1792, à qual se seguem a queda da monarquia, a proclamação da República, o julgamento e a execução do Rei, a radicalização do conflito entre jacobinos e girondinos, o banimento destes últimos e a proclamação do governo revolucionário, em outubro de 1793. A teoria do governo 
revolucionário é expressa por Maximilien de Robespierre, em seu Rapport sur les principes du gouvernement révolutionnaire, de 25 de dezembro de 1793. A base dessa teoria é a distinção entre governo constitucional e governo revolucionário: "O objetivo do governo constitucional é conservar a República; o do governo revolucionário é fundála” (ROBESPIERRE, 1840, p. 512). O jacobino se coloca no coração do conceito que Schmitt chamará de "ditadura soberana", frisando que o regime de exceção então em vigor não tem o objetivo de conservar uma Constituição já existente, mas preparar o terreno para o advento de uma nova ordem constitucional. Enquanto essa nova ordem constitucional ainda não estiver em condições de se estabelecer, a liberdade se encontra em guerra contra seus inimigos, de modo que a aplicação das garantias e dos princípios característicos do período em que a liberdade já é vitoriosa seria totalmente descabida. Isso equivaleria a "submeter ao mesmo regime a paz e a guerra, a saúde e a doença" (ROBESPIERRE, 1840, p. 513). O governo revolucionário é o governo da liberdade em guerra, de modo que ele "é submetido a regras menos uniformes e menos rigorosas, porque as circunstâncias em que se encontra são tempestuosas e cambiantes, e sobretudo porque ele é forçado a empregar sem cessar expedientes novos e rápidos para perigos novos e urgentes" (ROBESPIERRE, 1840, p. 512). No entanto, Robespierre afirma que o governo revolucionário "não tem nada em comum com o arbítrio" (ROBESPIERRE, 1840, p. 514), pois "ele se apoia sobre a mais santa de todas as leis, a salvação do povo; sobre o mais irrefragável de todos os títulos, a necessidade" (ROBESPIERRE, 1840, p. 514). Seu objetivo é reprimir a anarquia e a desordem "para trazer e consolidar o império das leis" (ROBESPIERRE, 1840, p. 514), não submeter o povo ao arbítrio de paixões particulares.

Embora Robespierre negue a vinculação entre o governo revolucionário e o arbítrio, ele se encontra no coração do que esta tese está considerando como o "problema do arbítrio" - ou seja, o problema das decisões políticas que não se justificam por leis ou princípios fixos. No discurso robespierrista, o arbítrio, entendido nesse sentido, é justificado em um estado de exceção compreendido pelo paradigma da ditadura soberana - em um estado pré-político caracterizado pela tentativa de fundação da República por meio da guerra. Nesse momento excepcional, nenhum dos princípios da República já constituída se aplica. A própria subordinação do Poder Executivo ao Legislativo é subvertida, com o órgão executivo do Comitê de Salvação Pública adquirindo proeminência sobre o poder legislativo da Convenção Nacional (GUENIFFEY, 2000, p. 
268; GAUCHET, 2018, p. 135-136). A particularidade do discurso jacobino, especialmente a partir de 1793, consiste em colocar mais ênfase sobre o momento revolucionário do que sobre o da República constituída, ${ }^{25}$ fazendo o estado de exceção adquirir uma dimensão política inaudita, pela qual o arbítrio, negado na política ordinária, torna-se absoluto e justificado no momento presente da Revolução.

Assim, de 1789 a 1794, o arbítrio é radicalmente negado pela cultura política do legicentrismo ${ }^{26}$ revolucionário, mas ele acaba entrando pela porta dos fundos do estado de exceção - pelas formas de "ditadura comissarial" previstas pela Constituinte, depois pela "ditadura soberana” do Comitê de Salvação Pública. Nesse período, afirmam-se ao mesmo tempo as concepções mais radicais de império da lei e as justificativas mais ousadas para a perseguição dos "inimigos do povo" sem a mediação de nenhuma lei. Quando os revolucionários franceses pensam o funcionamento das instituições políticas em períodos ordinários, a tendência geral é conceber a aplicação da lei, por parte dos poderes Executivo e Judiciário, como a conclusão de um silogismo que exclui toda decisão humana, como sintetiza Condorcet em "De la nature des pouvoirs politiques dans une nation libre", de novembro de 1792:

Entre a lei e a coisa que deve ser feita segundo ela, ou o indivíduo que deve se submeter a ela, encontra-se a função de declarar que tal é, em tal circunstância, a aplicação da lei, ou seja, a função de estabelecer um silogismo do qual a lei é a premissa maior, um fato mais ou menos geral, a premissa menor, e a conclusão, a aplicação da lei (CONDORCET, 1847, p. 595). ${ }^{27}$

${ }^{25}$ É a tese de Gueniffey, para quem o discurso jacobino não tem por objeto uma concepção da democracia, mas antes a própria revolução, “e antes seus meios do que seus fins” (GUENIFFEY, 2000, p. 224).

26 A expressão francesa légicentrisme é de aplicação controversa na teoria política. Segundo Pasquale Pasquino (1994b, p. 109, nota 10), essa palavra “é ou um sinônimo para expressões como rule of law ou Rechtsstaat, ou não tem um significado claro, a não ser como um antônimo de um décrétocentrisme específico de um governo despótico". Por isso, o autor prefere a expressão législativocentrisme, entendendo por isso a supremacia absoluta do Poder Legislativo em relação aos outros poderes. Utilizamos aqui "legicentrismo" em um sentido que transcende a supremacia do Poder Legislativo, resultando em uma sagração da lei que impossibilita o conceito de decisão.

${ }^{27}$ A compreensão da função judiciária como se resumindo à conclusão de um silogismo que afasta toda decisão já havia sido popularizada por Cesare Beccaria, como veremos no Capítulo 3 desta tese. Condorcet estende o raciocínio às funções do Poder Executivo, pensado como um calculador mais do que como uma verdadeira autoridade capaz de tomar uma decisão: “Os depositários desse poder não ordenam, eles raciocinam, eles buscam conhecer um fato, ou o constatam” (CONDORCET, 1847, p. 596). O 
Ao mesmo tempo em que, no plano das instituições políticas regulares, a maioria dos revolucionários franceses via toda vontade política ativa, capaz de tomar uma decisão, como "suspeita de ser o vetor de uma dominação ou de conduzir ao privilégio de interesses particulares" (ROSANVALLON, 2015, p. 39), a mesma Revolução legou para a posteridade uma das versões mais assustadoras do estado de exceção, na qual as punições arbitrárias e o terror são exaltados como uma emanação da virtude em guerra, como no relatório de Robespierre "sur les principes de morale politique qui doivent guider la Convention nationale dans l'administration intérieure de la République", lido à Convenção em 5 de fevereiro de 1794 (cf. ROBESPIERRE, 1840, p. 550).

Assentado sobre bases precárias, o governo revolucionário não conseguiu durar muito tempo após a derrubada de Robespierre, em 9 Termidor do Ano II (27 de julho de 1794). A própria Convenção termidoriana decide fazer a transição para o governo constitucional, elaborando a Constituição do Ano III (adotada em 22 de agosto de 1795). Quando Benjamin Constant chega a Paris, em maio de 1795, em companhia de Madame de Staël e determinado a participar dos eventos da Revolução Francesa, uma das questões colocadas com urgência era qual seria o lugar do arbítrio na nova ordem constitucional que se projetava.

\subsection{O liberalismo da ordem e a obliteração do problema do arbítrio}

A Constituição de 1795 é elaborada sob o signo da ruptura parcial com a cultura política revolucionária vigente até então. Em ruptura com a obsessão dos constituintes de 1789-1791 e de 1793 com a unidade do Poder Legislativo, a Constituição do Ano III estabelece a divisão do Legislativo em um Conselho dos Quinhentos e um Conselho dos Anciões. Em ruptura com o legicentrismo radical imperante até o 9 Termidor, os convencionais de 1795 decidem reabilitar parcialmente o Poder Executivo, a começar pela readmissão da expressão, substituída na Constituição de 1793 por "Conselho executivo". Além de empregar novamente a expressão "Poder Executivo", a Constituição

paradigma do silogismo, utilizado para pensar as relações entre os poderes Legislativo, Executivo e Judiciário, era recorrente na época da Revolução Francesa, encontrando outro exemplo na Metafísica dos Costumes de Kant, de 1797 (KANT, 2013, p. 119). 
de 1795 o dota de poderes acrescidos em relação aos de 1791 e 1793, procurando também atribuir a seus membros certa dignidade simbólica (MORABITO, 1996, p. 173-175). Não obstante, essas rupturas são apenas parciais, pois a divisão do Legislativo e a reabilitação do Executivo são introduzidas como novidades técnicas no interior de um quadro conceitual que ainda conserva os elementos centrais da cultura política revolucionária (GAUCHET, 1995, p. 154-155; MORABITO, 1996; TROPER, 2006). Assim, a divisão do Legislativo em dois conselhos não é pensada sob a chave do bicameralismo em sentido clássico (duas câmaras legislativas compostas por critérios distintos e armadas de prerrogativas semelhantes, como nos modelos britânico e norte-americano), mas antes como uma forma de dividir funcionalmente em duas seções uma mesma câmara legislativa, fazendo uma seção propor as leis e a outra votar sua admissão, de modo a evitar deliberações precipitadas e favorecer decisões sábias e meditadas. A reabilitação do Poder Executivo, por sua vez, ocorre em um quadro conceitual em que ele permanece subordinado ao Legislativo, sem qualquer possibilidade de fazer sua vontade prevalecer sobre a dos Conselhos. O Diretório, como é cunhado o Poder Executivo colegiado previsto na Constituição de 1795, permanece responsável perante o Legislativo, sem iniciativa das leis, nem direito de veto ou de dissolução dos Conselhos (MORABITO, 1996, p. 175).

A ruptura mais profunda com a cultura política revolucionária não deve ser buscada na própria Constituição de 1795, mas na enxurrada de críticas que se seguiu à apresentação do projeto constitucional da Comissão dos Onze e à proclamação da Constituição do Ano III, acusada por muitos de não romper suficientemente com os princípios impraticáveis vigentes desde 1789. Segundo Gauchet, "raramente uma Constituição terá entrado em vigor em meio a tal ceticismo e sob tal fogo crítico" (GAUCHET, 1995, p. 189). Entre os críticos da nova Constituição, destacam-se os nomes de Pierre-Louis Roederer e Adrien de Lezay-Marnésia. Por um lado, esses autores retomam as críticas de Stanislas de Clermont-Tonnerre e Jacques Necker à Constituição de 1791, dirigindo-as contra a Constituição de 1795. Por outro lado, Roederer e LezayMarnésia exercem, no período termidoriano, uma influência política e intelectual superior à que haviam exercido os críticos da Constituição de 1791, os quais haviam sido rapidamente marginalizados do debate político-intelectual, sob a pecha de inimigos da Revolução Francesa. Roederer e Lezay-Marnésia conseguem, ao contrário, elaborar suas críticas à Constituição do Ano III em um quadro teórico que se apresenta como 
republicano e partidário da obra da Revolução Francesa, de modo a servir não apenas como um aparato crítico, mas também como uma orientação para uma alternativa prática de construção institucional republicana.

Como caracterizar esse quadro teórico? Andrew Jainchill vincula o pensamento de Roederer (e também o de Sieyès) a um "autoritarismo liberal", caracterizando este último como a ideologia que presidiu à refundação da ordem política e social na esteira do golpe do 18 Brumário, clamando por uma autoridade forte e centralizada como a garantia principal da ordem e das liberdades individuais (JAINCHILL, 2008, Cap. 5). O termo é inspirado pelo livro de Howard Brown, Ending the French Revolution: Violence, Justice and Repression from the Terror to Napoleon, no qual o "autoritarismo liberal" é apresentado como a cultura política que conseguiu terminar a Revolução Francesa, por meio do apelo a um Estado de segurança autoritário consolidado sob Napoleão (BROWN, 2006, Parte III).

Esta tese se inspira pelos trabalhos de Brown e Jainchill, mas propõe a substituição da expressão "autoritarismo liberal" por "liberalismo da ordem". Enfatizamos, assim, uma dimensão importante da categoria empregada por Jainchill - a priorização da ordem sobre a liberdade política operada em um discurso como o de Roederer e Lezay-Marnésia (JAINCHILL, 2008, p. 201) -, mas ressaltamos que o autoritarismo bonapartista não era o resultado necessário e premeditado do apelo à ordem que eles faziam desde o 9 Termidor. Com efeito, a expressão "autoritarismo liberal" implica interpretar o pensamento em questão à luz de seu resultado histórico: o autoritarismo napoleônico. É verdade que personagens como Roederer, Lezay-Marnésia e Sieyès ajudaram Napoleão a chegar ao poder e a construir seu aparato estatal autoritário. É igualmente verdade que o autoritarismo era um dos resultados possíveis da escolha de privilegiar a ordem sobre a liberdade política, dado que essa escolha permite o sacrifício da liberdade em nome da ordem, quando esta última parece ameaçada. Contudo, a expressão "autoritarismo liberal" não fornece uma descrição acurada do problema enfrentado por autores como Roederer e Lezay-Marnésia após o 9 Termidor. O autoritarismo pode ter sido o resultado histórico da linha de pensamento desses autores, mas não seu ponto de partida. ${ }^{28}$

${ }^{28}$ É a razão pela qual a ênfase sobre a ideia de ordem nos parece mais exata do que sobre a ideia de autoritarismo. É verdade que o próprio termo "liberalismo" apresenta certo anacronismo, visto que ele não existe antes do século XIX. Isto posto, Jainchill tem razão em sublinhar a fidelidade do "autoritarismo 
O ponto de partida do pensamento de Roederer e Lezay-Marnésia após o 9 Termidor era o restabelecimento da ordem por meio da recuperação de um Poder Executivo forte e ativo, negado pela cultura política revolucionária vigente até aquele momento. O problema de como restabelecer a ordem e reabilitar o Poder Executivo não tinha como resposta, ao menos em um primeiro momento, a defesa de um regime autoritário. $\mathrm{O}$ autoritarismo era rejeitado por eles juntamente com a palavra arbitraire, associada então quase unanimemente às duas experiências igualmente indesejáveis do Antigo Regime e do Terror. Embora o "liberalismo da ordem" rejeitasse o autoritarismo, ele não enfrentava o que esta tese chama de "problema do arbítrio", ou seja, a questão de como evitar que a discricionariedade incorporada ao sistema político degenerasse em tirania. Enfrentado, à sua maneira, por autores como Locke e Rousseau, o problema do arbítrio não se colocava a Roederer e Lezay-Marnésia porque eles não viam um Poder Executivo dotado de prerrogativas discricionárias como propício a abusar dessas prerrogativas. Somava-se a isso uma leitura da Revolução Francesa que pintava o arbítrio como uma etapa já ultrapassada da Revolução, de modo que ele não se colocava mais como um problema para os momentos presente e futuro. O liberalismo da ordem nutria, assim, a ilusão segundo a qual era possível incorporar a discricionariedade ao sistema político sem haver "problema do arbítrio" a resolver.

Como já adiantado, Roederer e Lezay-Marnésia recuperam, em sua crítica da Constituição de 1795, argumentos já empregados por Clermont-Tonnerre e Necker em sua crítica da Constituição de 1791. Antigo líder dos derrotados monarquianos, ClermontTonnerre publica, em 1791, a Analyse Raisonnée de la Constitution Française décrétée par l'Assemblée Nationale, lamentando as escolhas dos constituintes de 1789-1791, as quais resultaram, segundo ele, na anulação do poder régio e na entrega de um poder absoluto e sem contrapeso à Assembleia Legislativa, a qual estaria em condições de escravizar o povo. Todavia, a verdadeira inspiração do liberalismo da ordem deve ser

liberal" de Roederer e Sieyès aos valores fundamentais do liberalismo moderno (ao menos em uma de suas vertentes), como a liberdade individual, a inviolabilidade da propriedade, etc. Além disso, se considerarmos genericamente como liberais aqueles que, no fim do século XVIII e início do XIX, defendiam a Revolução Francesa, mas condenavam seus excessos (o sentido que se atribuía à identidade liberal nos primórdios da utilização política do termo), Roederer e Lezay-Marnésia pertenciam claramente a esse grupo. É a razão pela qual esta tese aplica o termo "liberalismo" a esses autores, apesar da inexistência da expressão na época. 
buscada no livro Du Pouvoir Exécutif dans les Grands États, publicado por Necker em 1792. Assim como Clermont-Tonnerre, o objetivo de Necker é denunciar as consequências nefastas do esquecimento do Poder Executivo por parte da Assembleia Nacional Constituinte. Entretanto, sua ênfase não reside na crítica da onipotência do Legislativo em nome do equilíbrio dos poderes, mas na elevação da ordem social em valor político fundamental e na consideração do Poder Executivo como o guardião dessa ordem. Vale a pena se deter por um momento nesse argumento, o qual será crucial para a maneira como Roederer e Lezay-Marnésia obliteram o problema do arbítrio.

“(...) a composição do Poder Executivo constitui a principal, e talvez a única, dificuldade de todos os sistemas de governo. Esse poder, embora o segundo em aparência no ordenamento político, desempenha nele o papel essencial" (NECKER, 1792, p. 18). Com essa afirmação, Necker subverte todo o "sistema de legitimidade dos modernos" (GAUCHET, 2017, p. 236), o qual, pelo menos desde Locke, concebe o Legislativo como o poder supremo, e o Executivo, como um poder subordinado. Mais precisamente, o autor não contesta diretamente o sistema de legitimidade dos modernos enquanto tal, mas antes a maneira de raciocinar que só se preocupa com a questão da legitimidade, ao passo que a questão verdadeiramente difícil reside em outra dimensão. Essa outra dimensão é o que podemos chamar de o mistério da obediência: "É na formação da obediência, é na combinação dos meios necessários para assegurar a subordinação geral, sem despotismo e sem tirania, que repousam toda a ciência política e toda a dificuldade do ordenamento social” (NECKER, 1792, p. 302).

Toda a reflexão política de Necker parte da constatação de que a obediência às leis não é um dado, mas um verdadeiro mistério. Ela não decorre automaticamente do fato de haver boas leis, ou leis emanadas de uma fonte legítima. Pelo contrário, toda a dificuldade da construção política diz respeito ao estabelecimento de uma autoridade capaz de impor a obediência às leis sem o recurso aos meios tirânicos. Essa autoridade é associada pelo autor ao Poder Executivo, concebido sob a forma do poder régio. Mais do que um simples executor da lei, o Executivo é pensado como um garantidor da ordem, logo da obediência à lei, sem a qual sua mera execução se tornaria vã ou tirânica. Nessa perspectiva centrada sobre a eficácia da autoridade, mais do que sobre sua legitimidade abstrata, a ordem se torna o objetivo principal do pacto social e da associação política, acima do objetivo, normalmente prioritário, da liberdade: 
Quando os homens estabeleceram um pacto social, eles não tiveram por objetivo atingir um sistema de liberdade, não somente completo em todas as suas partes, mas ainda ao abrigo de toda espécie de acaso imaginável. Pois, se sua ambição não tivesse tido outro termo; se esse objetivo tivesse sido o único objeto de seus votos, eles teriam permanecido o que eram originariamente, hordas de selvagens, tendo chefes apenas por intervalos, e se liberando à vontade dessa autoridade passageira (NECKER, 1792, p. 315).

Para Necker, a sociedade política é o produto de uma evolução da civilização que conduziu ao desenvolvimento da propriedade, das ideias de justiça e do desejo de ordem e segurança, suscitando a necessidade

(...) de uma força política, de uma força que, depositada em mãos esclarecidas, servisse para garantir as convenções sociais e para fazer todos os cidadãos gozarem de uma segurança, transformada necessariamente em um de seus votos mais caros, desde a sua nova fortuna e suas novas ideias (NECKER, 1792, p. 316).

A ordem constituindo, assim, o objetivo essencial do pacto social, "o sacrifício absoluto da ordem à liberdade deveria ser considerado como uma perturbação na série natural das ideias sociais" (NECKER, 1792, p. 317). O autor admite a liberdade como um valor de primeira ordem, mas cuja perseguição só deve começar depois que a ordem pública já esteja bem estabelecida. "Tudo nos convida a pensar, portanto, que a ordem pública, essa ideia tutelar, essa ideia conservadora do mundo moral, é a condição primeira de todas as instituições sociais” (NECKER, 1792, p. 318).

Como garantir a ordem e a obediência à lei sem o recurso à tirania ou ao despotismo: eis o problema político fundamental do liberalismo da ordem avançado por Necker. A preocupação em evitar os meios despóticos ou tirânicos justifica a preferência desta tese pela expressão "liberalismo da ordem", em detrimento de "autoritarismo liberal". A especificidade do liberalismo da ordem, ao menos nesse primeiro momento, não consistia em um apelo ao autoritarismo, mas em uma divergência em relação à cultura política revolucionária a respeito de como evitar o retorno do despotismo. A compreensão que havia predominado na Constituinte era a de que o despotismo só poderia ser evitado por meio de uma concepção absoluta de império da lei, a qual implicava um Poder Executivo completamente subordinado ao Legislativo, sem autorização para tomar decisões discricionárias, como na teoria de Rousseau. Necker não podia aceitar essa concepção absoluta de império da lei, pois, para ele, a anulação do Poder Executivo equivalia ao aniquilamento da ordem. Contra a obra dos constituintes franceses, ele erige em modelo, tal como os monarquianos, a constituição inglesa:

Os ingleses, instruídos pela experiência e por suas reflexões sobre a importância do Poder Executivo, e sobre as dificuldades às quais a formação 
desse poder é sujeita, não negligenciaram nenhum dos meios próprios a o consolidar sem risco. (...) eles fizeram aparecer a autoridade do Monarca, todas as vezes em que essa intervenção não ofendia a liberdade civil e política (NECKER, 1792, p. 154-155).

Para o antigo ministro de Luís XVI, a Revolução Francesa deveria ter conservado todas as prerrogativas régias existentes na constituição inglesa: direito de encurtar a duração do Parlamento e convocar novas eleições, direito de veto absoluto sobre as leis, designação dos juízes, direito de graça, um grande número de nomeações, empregos e dignificações à disposição, além dos atributos simbólicos que garantem a majestade da Coroa. Desse modo, seria possível, segundo o autor, um Poder Executivo forte e garantidor da ordem, mas de modo algum despótico, como na Inglaterra.

Em oposição aos constituintes informados por Rousseau, Necker não vê na proibição de todo uso discricionário do poder por parte do Rei uma maneira de evitar o despotismo. Pelo contrário, segundo ele, um Rei que pode decidir discricionariamente sobre a duração do Parlamento, a adequação das leis, a designação dos juízes, a necessidade de revogar ou comutar penas etc. tem menos chance de virar um déspota do que um monarca privado desses poderes. "Não é com correntes tecidas pela desconfiança que se pode manter todos os poderes em seus limites constitucionais " (NECKER, 1792, p. 326), escreve o autor, propondo, no lugar dessas correntes de desconfiança, o emprego de um "laço da felicidade, esse laço tão suave, tão flexível, que, sem prejudicar a ação universal, retém cada um em seu lugar" (NECKER, 1792, p. 326):

Os ingleses (...) nos haviam fornecido a ideia de uma tal organização do
governo. A política, assim como um sentimento moral, havia lhes imposto o
dever dessas combinações sábias, as quais tornaram o Monarca, a Nação e seus
Representantes igualmente contentes com seus direitos, com suas funções e
com seus privilégios. Admirável harmonia, que esconde e atesta, ao mesmo
tempo, toda a ciência do Legislador!

No sistema de harmonia pregado por Necker - oposto ao sistema de equilíbrio dos poderes, "embora o argumento não lhe seja estrangeiro" (FURET; HALÉVI, 1996, p. 250) -, as prerrogativas régias não degeneram em tirania graças à satisfação do Rei com seu poder e sua posição. "Pois, quando ele foi tornado contente com seu destino régio, ele pode ser determinado, em todas as suas ações, unicamente pelo objetivo do bem público. Mas, em outra situação, é ao crescimento de seu poder que todos os seus meios são destinados" (NECKER, 1792, p. 239).

Necker se faz, assim, o pioneiro de um argumento que será diversas vezes repetido por Roederer e Lezay-Marnésia durante o Diretório: o Poder Executivo perigoso para a 
liberdade é justamente aquele que não está assegurado de seu poder e de sua força. Com esse argumento, é todo o medo dos primeiros constituintes em relação ao arbítrio dos poderes não controlados pela Assembleia que é abandonado. Com a emergência do liberalismo da ordem sob a pena de Necker, o arbítrio começa a ser negado como problema. Se um Rei dotado de poderes discricionários não abusa desses poderes porque ele se satisfaz com eles, o problema do arbítrio, compreendido como o da regulação dos poderes que não se limitam a uma estrita aplicação da lei, desaparece. $\mathrm{O}$ arbítrio pode ser incorporado à Constituição sem que se preocupe em como evitar sua degeneração em tirania. A discricionariedade atribuída ao Poder Executivo não implica de modo algum um perigo de subversão da Constituição, das leis e da liberdade.

Como já sugerido, Roederer e Lezay-Marnésia adaptam, após o 9 Termidor, o liberalismo da ordem de Necker para um quadro explicitamente republicano e partidário da obra de Revolução Francesa, possibilitando uma maior influência dessa corrente de pensamento como alternativa de construção institucional republicana. Roederer foi um personagem extremamente influente durante a Revolução Francesa e o período napoleônico, embora pouco conhecido atualmente na teoria política, apesar de alguns estudos e tentativas de interpretação (RADEMACHER, 2001; CHAPPEY, 2003; JAINCHILL, 2008, p. 204-211). Deputado na Constituinte e procurador-geral-síndico do Sena na época da Revolução de 10 agosto de 1792, ele se torna uma figura maior do debate político após o 9 Termidor, notadamente por sua atividade jornalística e sua posição de membro do Institut national de France a partir de dezembro de 1795. Quanto à atividade jornalística, ele se torna, em janeiro de 1795, coproprietário do influente Journal de Paris, criando ainda o Journal d'économie publique, de morale et de politique, ativo de agosto de 1796 a outubro de 1797, e outros jornais durante o Consulado e o Império. ${ }^{29}$ Lezay-Marnésia era um colaborador bastante próximo de Roederer, participando da produção de artigos para o Journal d'économie publique e tendo seus textos divulgados por Roederer. Embora eles nunca tenham se proclamado explicitamente como continuadores de Necker, ${ }^{30}$ há uma continuidade evidente com o autor de $D u$

\footnotetext{
${ }^{29}$ Sobre a atividade jornalística de Roederer, ver: CHAPPEY, 2003.

30 A visão nuançada de Roederer sobre Necker é exposta em uma carta à filha deste último, Madame de Staël, datada provavelmente de setembro de 1796. Roederer escreve que "nenhum homem na França reverencia mais do que eu o Sr. Necker em termos de talento como de virtude, talentos literários e administrativos ao mesmo tempo. Devo muito ao estudo de seus livros. Durante muito tempo, eu o
} 
Pouvoir Exécutif dans les Grands États sobre o tema da centralidade da ordem: “A ordem, a ordem: eis o objeto de toda Constituição, a missão de todo governo, o princípio de toda prosperidade pública" (ROEDERER, 1796-1797, tomo I, p. 3), escreve Roederer na Introdução ao primeiro volume de seu Journal d'économie publique.

Como Necker, Roederer e Lezay-Marnésia fazem uma associação direta entre a garantia da ordem e a força do Poder Executivo. Como já sugerido, eles transplantam a reflexão de Necker sobre o Poder Executivo, formulada no contexto da crítica da Constituição de 1791, para uma crítica da Constituição de 1795. Lezay-Marnésia reage à elaboração dessa Constituição pela Comissão dos Onze com um violento panfleto, Qu'est-ce que la Constitution de 95 ?. A perspectiva, apresentada desde a Introdução, é a de contribuir para terminar uma revolução da qual todos os franceses estão cansados. As lições das infelicidades da Revolução são extraídas em conformidade com os valores centrais do liberalismo da ordem:

Nela, leremos que os homens pagam sempre mais caro pelo esquecimento de seus deveres do que pelo de seus direitos, e que os excessos de um Poder sem limites não vão nunca tão longe quanto os de uma Liberdade sem freio. Veremos nela que o amor pela novidade foi o princípio de nossos males, e a ignorância dos Inovadores, sua medida. Nós os veremos se enganando sobre tudo: estendendo a Vontade do povo, antes de haver estendido sua Razão; e, tendo começado por lhe dar a Liberdade, não podendo mais lhe dar a Ordem (LEZAY, 1795, p. iii).

E, um pouco adiante:

Em qualquer Sociedade civilizada, ou seja, onde quer que a Propriedade tenha lançado raízes profundas, a consideração pela Liberdade passará sempre depois da consideração pela ordem, os interesses políticos depois dos interesses civis, pois é a ordem, e não a Liberdade, que lhes assegura a garantia (LEZAY, 1795, p. viii-ix).

Tendo a ordem como preocupação central, a fraqueza e a falta de unidade do Poder Executivo serão os aspectos da Constituição de 1795 mais criticados por Lezay-Marnésia: "da maneira como a Comissão o dotou, trata-se antes de um inimigo que se amarra a correntes, do que de um Protetor que cobre tudo com sua poderosa mão, e que representa em sua pessoa a majestade nacional" (LEZAY, 1795, p. 42; ênfase do autor). Como Necker, o autor crê que um Executivo forte é menos perigoso do que um Executivo fraco,

considerei um grande administrador, mas de modo algum um legislador. Sua obra sobre o Poder Executivo me fez mudar de opinião" (ROEDERER, 1853-1859, vol. 8, p. 648). Ver também a resenha de Roederer sobre De la Révolution française de Necker, de 1796, no Journal d'économie publique, de morale et de politique (ROEDERER, 1796-1797, tomo III, p. 201-210). 
pois este último tentará retomar a força intrínseca a sua natureza por meios extra-legais: "Em todos os casos, parece-me, é melhor dar do que deixar tomar: ao despojar o Poder Executivo de sua prerrogativa natural, a de julgar sobre aquilo que ele é encarregado de fazer, nós o forçamos a recorrer ao meio secreto de retomar essa prerrogativa" (LEZAY, 1795, p. 42-43; ênfase do autor). Esse meio secreto é, para Lezay-Marnésia, uma influência corruptora sobre o Poder Legislativo, principalmente o Conselho dos Anciões. $\mathrm{O}$ autor defende, portanto, um Poder Executivo unificado (não colegiado, como o Diretório criado pela Constituição do Ano III), com um mandato longo (cinco anos), munido de um direito de veto, cercado de brilho e capaz de distribuir grandes recompensas.

Roederer intervém no mesmo debate com uma série de artigos no Journal de Paris, que ele condensa na brochura Du Gouvernement, de julho de 1795. Ele considera, "como condições necessárias de um bom governo, a atividade, a força e a retidão" (ROEDERER, 1795, p. 9). Curiosamente, uma preocupação próxima da de Necker e Lezay-Marnésia (fortalecer um Poder Executivo compreendido como o guardião da ordem) é expressa em uma linguagem largamente emprestada de Rousseau, de quem o texto é repleto de citações. ${ }^{31}$ Com efeito, a condição da retidão, aplicada ao governo, é compreendida como "a conformidade de sua organização, de suas decisões e de seus atos, não apenas com as leis, mas também com os princípios" (ROEDERER, 1795, p. 12; ênfases do autor) - o autor fazendo um apelo à ideia, cara a Rousseau, de um governo em conformidade com os comandos da lei, entendida como expressão da vontade geral. Contudo, o desafio encarado por Roederer consiste em conciliar a retidão do governo (sua submissão às leis e aos princípios) com sua atividade - ou seja, "a faculdade de tomar prontamente suas determinações", "a subordinação de seus agentes" e "sua capacidade" (ROEDERER, 1795, p. 9) - e com sua força, a qual supõe "a independência de seu poder, e essa independência supõe, por sua vez, uma garantia forte e solene contra o corpo legislativo" (ROEDERER, 1795, p. 10).

Ora, segundo o autor, a atividade do governo projetado pela Comissão dos Onze é comprometida principalmente pela nomeação dos agentes locais pelo povo e pela multiplicação de conselhos locais, de modo que "o comando, caindo de autoridade em autoridade, encontra em todo lugar a deliberação antes da obediência!” (ROEDERER,

\footnotetext{
${ }^{31}$ O “rousseauísmo" de Roederer é sublinhado por RADEMACHER, 2001.
} 
1795, p. 18). Não obstante, o que Roederer enfatiza mais intensamente é a falta de força do Poder Executivo da nova Constituição, relacionando essa fraqueza com uma ausência de garantias políticas e judiciárias contra o Poder Legislativo. O projeto dos Onze "reduz o governo a receber em silêncio, a publicar, a proclamar imediatamente a lei, o ato mais destrutivo em relação ao próprio governo" (ROEDERER, 1795, p. 21). Além disso, o Poder Executivo tem apenas "uma fraca garantia contra os julgamentos iníquos" (ROEDERER, 1795, p. 26) do Legislativo.

Defendendo o estabelecimento de garantias políticas e judiciárias mais eficazes do Poder Executivo contra o Legislativo, Roederer enfrenta a objeção hipotética segundo a qual, "com o cuidado de o preservar contra os ataques do corpo legislativo, vocês o tornam perigoso para este último, e vocês esquecem que não é menos importante garantir um do que o outro" (ROEDERER, 1795, p. 29). A resposta do autor a essa objeção é reveladora de sua visão sobre a natureza dos poderes Executivo e Legislativo e sobre a possibilidade do arbítrio nessa relação. De acordo com ele, "o corpo legislativo é paralítico por sua natureza; ele é o órgão, e não o instrumento, da vontade nacional. Atribuam-lhe outras funções além das que lhe são próprias, e vocês constituirão nele a tirania " (ROEDERER, 1795, p. 22). A conceituação é rousseauniana, na medida em que o Legislativo é concebido como o órgão da vontade nacional, tendo a faculdade de tudo querer e tudo ordenar, mas não a de agir. O governo é concebido como um instrumento encarregado de aplicar a lei proclamada pelo legislador, Roederer sublinhando, a esse respeito, que ele deve ter o monopólio dos meios de ação (principalmente, a disposição das forças armadas e do tesouro público): "o governo só pode ser garantido contra os atos do corpo legislativo na medida em que a Constituição proibir todo ato ao corpo legislativo, e reservar os meios de ação exclusivamente para o Poder Executivo" (ROEDERER, 1795, p. 22). O autor argumenta que o Poder Executivo só estará em segurança, ao lado do Legislativo, se aquele tiver o monopólio dos meios de ação e um direito de se defender das leis usurpadoras. Por outro lado,

(...) apesar dessa investidura, o corpo legislativo fica plenamente seguro ao lado do Poder Executivo. A garantia de quem executa contra quem comanda só pode residir na faculdade de se opor ao comando que lhe ordenaria de perecer, assim como na certeza de que aquele que pronunciou tal ordem não tem em suas mãos o meio de a executar por si mesmo. Mas a garantia de quem comanda contra quem se limita a executar reside na impotência deste último para executar qualquer coisa que não the tenha sido ordenada (ROEDERER, 1795 , p. 29). 
Nessa citação, nota-se uma combinação interessante entre uma concepção rousseauniana das relações entre os poderes Legislativo e Executivo (o Legislativo tem o monopólio da vontade, ao passo que o Executivo tem o monopólio da ação) e uma preocupação, inspirada antes em Necker, de evitar, em nome da ordem, a aniquilação do Poder Executivo pelo Legislativo. Como Necker e Lezay-Marnésia, Roederer tem a convicção de que um Poder Executivo forte e independente não é, de modo algum, perigoso para a liberdade, pois o que ameaça verdadeiramente a liberdade é um governo insatisfeito com sua posição. $\mathrm{O}$ autor acrescenta a essa convicção considerações relativas à própria natureza do Poder Executivo: sendo apenas um poder subordinado encarregado de aplicar a lei, uma eventual margem de decisão discricionária concedida a ele não degeneraria nunca em tirania. Pelo contrário, o poder de julgar a respeito da apropriação das leis só seria exercido pelo Executivo para se defender dos eventuais ataques do Legislativo, a fim de preservar os poderes da República.

Assim, a proposta de Roederer, em 1795, não é explicitamente autoritária. Conceituando o Poder Executivo de modo rousseauniano, sua preocupação é apenas evitar sua anulação, conferindo-lhe meios de defesa contra as invasões do Legislativo. As recomendações práticas extraídas dos princípios desenvolvidos na brochura são, em todo caso, tímidas: apesar da sugestão implícita, o autor não defende explicitamente, como Lezay-Marnésia, o direito de veto, ainda abominado três anos após a abolição da monarquia (GAUCHET, 1995, p. 157). Após examinar várias propostas práticas sobre como conciliar, no governo, a atividade, a força e a retidão, Roederer apoia a que obriga os cinco diretores executivos a serem escolhidos no Conselho dos Anciões e a permanecerem nesse Conselho após a escolha. O pressuposto é que, permanecendo membros do Poder Legislativo, os diretores executivos terão os meios de o influenciar no sentido de não atacar o Executivo e não fazer leis contrárias a sua conservação - um pressuposto, aliás, fortemente inspirado na obra de Necker, que havia elogiado o modelo inglês, no qual os ministros são comumente membros do Parlamento, os quais o instruem sobre as necessidades do Poder Executivo (NECKER, 1792, Cap. 11). ${ }^{32}$ O que nos interessa, assim, na brochura de Roederer de 1795 não é uma antecipação do autoritarismo

${ }^{32}$ Madame de Staël já havia sugerido a Roederer, em uma carta de 9 de junho de 1795, que a melhor maneira de fazer o Poder Executivo participar da elaboração das leis, na impossibilidade do veto característico da monarquia, era "escolher os ministros entre os representantes da Câmara do Senado" (STAËL apud ROEDERER, 1853-1859, vol. 8, p. 646). 
napoleônico, com seu Poder Executivo todo-poderoso, mas antes a asserção segundo a qual a independência do Poder Executivo não levanta o problema do arbítrio.

Desse modo, Lezay-Marnésia e Roederer contornam o problema do arbítrio, por meio de uma concepção do Poder Executivo inspirada pela obra de Necker, segundo a qual a concessão de uma margem de decisão discricionária ao governo não apresenta o perigo de um Poder Executivo tentado a se colocar acima da lei. No entanto, essa obliteração do problema do arbítrio não se liga apenas a uma compreensão institucional do papel do Poder Executivo, mas também a uma leitura da história da Revolução Francesa guiada por uma teoria das paixões políticas, do sentimento geral e da opinião pública. Essa teoria foi elaborada pelos dois autores conjuntamente, principalmente em um texto intitulado "Da la majorité nationale", cuja escrita foi reivindicada por Roederer (ROEDERER, 1853-1859, vol. 6, p. 376-381), mas que foi publicado pela primeira vez como o Capítulo 2 da brochura de Lezay-Marnésia, De la faiblesse d'un gouvernement qui commence, et de la nécessité où il est de se rallier à la majorité nationale, de 1796 (ano IV).

Nesse capítulo, os dois autores propõem uma apreensão sociológica da vida política (cf. RADEMACHER, 2001), na qual o mais determinante não é a maioria legal - ou seja, "essa maioria numérica dos votantes de uma nação” (LEZAY, 1796, p. 14) -, mas antes a maioria nacional, compreendida como a massa que, incluindo setores excluídos da maioria legal, como as mulheres, os adolescentes e os serviçais domésticos, "faz-se sentir em todas as partes" (LEZAY, 1796, p. 15), mesmo sem ter um canal oficial de expressão. Suas duas expressões são o sentimento geral e a opinião pública, os quais devem ser sempre considerados pela maioria legal encarregada de expressar a vontade oficial da nação. Roederer e Lezay-Marnésia elaboram uma teoria da formação dessas duas expressões da maioria nacional, a qual parte de uma concepção piramidal da sociedade. Segundo essa teoria, "o sentimento público nasce sempre nas classes inferiores do povo, ou seja, entre os mais pobres e mais limitados" (LEZAY, 1796, p. 18; ênfases do autor), subindo gradualmente até chegar ao topo da pirâmide social, onde se encontram os mais ricos e os espíritos mais esclarecidos. Esses homens de riquezas e de luzes interpretam o sentimento geral e lhe dão uma expressão intelectual, começando desse modo a opinião pública. Esta faz então o caminho inverso do sentimento geral, partindo da elite social e descendo gradualmente até as classes inferiores do povo, de modo a 
estabelecer sua autoridade sã e durável à medida que ela "cobre toda a superfície do Estado" (LEZAY, 1796, p. 28).

Como se pode ver, Roederer e Lezay-Marnésia fazem da "maioria nacional" o objeto de uma sociologia ao mesmo tempo descritiva e normativa. Eles elaboram uma teoria descritiva da formação dos sentimentos e das opiniões dominantes em uma sociedade, chegando, antes de Marx e Engels, à concepção segundo a qual as ideias dominantes em uma sociedade são as ideias formuladas pela classe dominante. No entanto, essa sociologia é também normativa, no sentido de que ela fornece critérios para avaliar se dado sentimento ou opinião pode ser considerado como uma expressão da maioria nacional, tendo, assim, legitimidade para ser traduzido pela maioria legal em leis. O critério central é, em poucas palavras, o filtro da propriedade e das luzes - ou seja, da elite social e cultural:

(...) toda opinião formada por procedimentos diferentes em relação àqueles de que falamos não é digna do título de opinião pública, não tem nenhuma estabilidade e, sobretudo, é incapaz de lutar contra a opinião que se estabeleceu daquele modo. Toda ideia lançada imediatamente sobre o povo, em vez de lhe ser insinuada gota a gota, por assim dizer, ou perece em seguida, sufocada pela dupla compressão das luzes e das riquezas, ou, no máximo, serve de alimento a alguma paixão efêmera, a qual ela consegue manipular por um momento, e que a devora e a aniquila em seguida. As verdades mais puras precisam cair do alto para penetrar as classes inferiores do Estado (LEZAY, 1796, p. 30).

Antecipando toda uma tendência da teoria política do século XIX, a qual insistirá na antecedência e na prioridade do social sobre o político, ${ }^{33}$ Roederer e Lezay-Marnésia fazem da maioria nacional o critério de legitimidade das decisões políticas, e da elite sociocultural o lócus da formulação autêntica da opinião pública encarregada de expressar o que aspira verdadeiramente a maioria nacional. Mais do que sua organização institucional, o que confere legitimidade e estabilidade a um governo é sua conformidade com o voto da maioria nacional, tal como expresso pela classe proprietária e instruída:

E, como a expressão do sentimento geral e a iniciativa da opinião pertencem aos proprietários, como eles são seus guias e seus órgãos, é a seus interesses, é a seus discursos, é a suas leituras, é aos livros, aos jornais que circulam entre eles, que o governo deve dar toda a sua atenção (LEZAY, 1796, p. 32).

Em De la faiblesse, Lezay-Marnésia analisa a opinião da maioria nacional nas diversas etapas de uma revolução popular, tendo como referência central a Revolução

\footnotetext{
${ }^{33}$ Rademacher (2001) sugere a influência de Roederer sobre teóricos do século XIX como o Conde
} de Saint-Simon e Auguste Comte. Devido a sua insistência na necessidade de aproximar o governo das elites sociais e culturais, ele pode contar também entre as influências de François Guizot e dos doutrinários. 
Francesa. A opinião pública pode se inclinar mais para o lado direito ou para o lado esquerdo, raciocina o autor, pioneiro da aplicação da dualidade direita/esquerda para a análise da disputa política. "Por lado direito, deve-se entender o partido conservador ou constitucional, e, por lado esquerdo, o partido revolucionário ou destruidor" (LEZAY, 1796, p. 33, nota 1; ênfases do autor). As revoluções populares sempre começam porque há uma maioria inclinada para o lado esquerdo, mas a tendência é que, à medida que a revolução cumpre sua tarefa e começa a decrescer, "sua própria maioria decresce, e, com a revolução acabada, o lado revolucionário fica em minoria” (LEZAY, 1796, p. 34). As revoluções populares são conduzidas primeiro pelos partidários da liberdade, a qual se torna, durante esse momento, a paixão dominante. Em seguida, a igualdade, sendo ainda mais popular do que a liberdade, torna-se a paixão dominante, formando uma maioria em seu favor. Essa segunda etapa da revolução é a mais furiosa e turbulenta, terminando por cansar todas as classes sociais e por inspirar em toda a sociedade a necessidade e o desejo da ordem:

Por onde se vê que essas três coisas, a liberdade, a igualdade e a ordem, devem, em uma revolução popular, dominar cada uma de uma vez: a liberdade, no começo; a igualdade, no meio; e a ordem no fim, cada uma sendo, nesses diversos períodos, a mais popular das três (LEZAY, 1796, p. 37).

Desse modo, Lezay-Marnésia caracteriza o momento pós-termidoriano no qual ele escreve como marcado pelo desejo majoritário da ordem. O governo vigente é fraco por causa de sua condição de recém-nascido, mas ele pode se estabilizar apoiando-se sobre essa maioria nacional típica do momento final das revoluções, a qual não deseja outra coisa além de um governo sólido e protetor da ordem. A teoria das fases da Revolução e a da formação da opinião pública convergem, portanto, para indicar ao governo vigente um apoio sólido sobre o desejo de ordem vocalizado principalmente

${ }^{34}$ Essa dualidade tem sua origem na divisão estabelecida na Constituinte no verão de 1789, por ocasião dos debates sobre os direitos do homem e sobre o veto monárquico. No entanto, Gauchet considera essa data de nascimento como um "falso ponto de partida" (GAUCHET, 1992, p. 402), pois o emprego da bipartição direita-esquerda permanece, durante a Revolução Francesa, tímido, irregular e limitado à esfera das atas parlamentares. Além disso, a filosofia da unidade então em vigor impedia o reconhecimento oficial das divisões partidárias, a ponto de a Constituição de 1795 prever, sob a proposição de La RevellièreLepeaux, a determinação dos assentos parlamentares por sorteio, a fim de evitar a divisão espacial da assembleia em grupos inimigos (GAUCHET, 1992, p. 401). Nesse contexto ilustrado por Gauchet, o emprego da divisão direita-esquerda por Lezay-Marnésia é verdadeiramente pioneiro, na medida em que ele a aplica para se referir a tendências profundas no interior da sociedade e da opinião pública - um uso da bipartição direita-esquerda que Gauchet remete antes ao início do século XX. 
pelos proprietários. Trata-se de uma teoria otimista segundo a qual a Revolução Francesa já terminou, o desejo geral de ordem constituindo o signo visível dessa conclusão da Revolução. A alteração da face do poder político após o 9 Termidor seria ela mesma a confirmação dessa entrada na era da ordem, segundo o critério estabelecido por LezayMarnésia: "Julgaremos que a época da ordem chegou quando os novos eleitos do povo forem menos revolucionários do que seus predecessores, o que será uma prova de que o próprio povo está menos revolucionário" (LEZAY, 1796, p. 37).

É essa conclusão da Revolução Francesa por meio da entrada na época da ordem que, ao lado das análises sobre a natureza do Poder Executivo, assegura Roederer e Lezay-Marnésia sobre a possibilidade de um governo forte que não apresenta o perigo do arbítrio. Eles veem o arbítrio como um traço indissociável da segunda fase da Revolução, aquela que havia sido guiada pela paixão dominante pela igualdade, como será exposto claramente na brochura de Lezay-Marnésia intitulada Des causes de la Révolution et de ses résultats, de 1797, a qual será analisada na Seção 1.4. Segundo os autores, um governo que se apoia sobre o desejo geral de ordem não será nunca arbitrário, mesmo se ele não se reduz a uma execução mecânica das decisões do Poder Legislativo. Eles creem que o fim da Revolução Francesa instaurou a possibilidade de um governo independente do corpo legislativo, mas que não sente, de modo algum, a necessidade de se colocar acima da lei.

Uma das primeiras ocasiões para a manifestação desse diagnóstico otimista foi o debate sobre os decretos dos dois terços, em 1795. As leis de 5 e 13 Frutidor do Ano III (22 e 30 de agosto de 1795), batizadas de decretos dos dois terços, obrigavam as assembleias eleitorais a reter no futuro corpo legislativo, a ser eleito segundo os critérios da nova Constituição, dois terços dos membros da Convenção que chegava a seu fim. Os partidários desses decretos os apresentavam como a única maneira de interromper o curso caótico da Revolução, assegurando-se contra "a formidável capacidade da Revolução de fazer brotar novos botões, de fazer surgir sem cessar novas "jornadas"” (OZOUF, 1996, p. 196). Ora, é justamente esse perigo que é negado por Roederer, em seu artigo no Journal de Paris intitulado "Quelques mots sur la prorogation des deux tiers de la Convention dans la Législature", de 22 a 24 Frutidor do Ano III (8 a 10 de setembro de 1795) (ROEDERER, 1853-1859, vol. 6, p. 113-118). Nesse artigo, o autor critica “os escritores que se encarregaram de realizar, em negócio com o Estado, a perseguição do monarquismo" (ROEDERER, 1853-1859, vol. 6, p. 113), avançando que "se (...), em vez 
de consultar esses escritores interessados, consultarmos as circunstâncias que, em todos os tempos, indicaram o espírito da maioria dos votantes, veremos como muito provável a boa composição da legislatura" (ROEDERER, 1853-1859, vol. 6, p. 113). Contra uma Convenção disposta a limitar a liberdade eleitoral para se proteger de uma maioria nacional supostamente guiada pelo ressentimento contra o Terror, Roederer sustenta que "o espírito geral não é um espírito de vingança e de assassinato" (ROEDERER, 18531859, vol. 6, p. 116). O voto geral da nação seria pelo repouso e pela ordem pública, o que já teria se manifestado na nomeação popular de funcionários públicos favoráveis à República, seja por opinião ou por amor da ordem e fidelidade ao regime estabelecido. "Essa espécie de homens pacíficos é aquela de que necessitamos para compor uma legislatura cujo dever mais importante será respeitar a independência do Poder Executivo" (ROEDERER, 1853-1859, vol. 6, p. 114). Essa citação condensa toda a visão de Roederer. A independência do Poder Executivo é erigida em necessidade central exigida pelo imperativo da ordem, mas a necessidade do arbítrio (nesse caso, na forma da limitação da liberdade eleitoral sob a justificativa da proteção da República contra uma maioria potencialmente contrária a ela) é rejeitada como deslocada nesse novo momento de conclusão da Revolução marcado pelo desejo geral de ordem. Haveria uma comunhão de sentimentos e de necessidades entre o governo republicano e a maioria nacional, de modo que o primeiro deveria ser independente do Poder Legislativo em sua qualidade de guardião da ordem, mas ele não experimentaria nunca a necessidade do arbítrio em suas relações com a maioria nacional. O arbítrio é compreendido por Roederer como uma herança do Terror (ou seja, da segunda fase da Revolução, guiada pela paixão pela igualdade), a qual permanece na maneira de agir da maioria da Convenção pela força do hábito, mas que não tem nenhuma necessidade no atual estado de coisas. $\mathrm{O}$ autor chega a sugerir que a única condição para a eliminação completa do arbítrio é a retirada dessa Convenção que "tem os hábitos da tirania" e "gosta do poder arbitrário como meio" (ROEDERER, 1853-1859, vol. 6, p. 114). Assim, para Roederer, o arbítrio é uma herança do passado recente, mas não uma ameaça para o presente ou o futuro.

\subsection{Benjamin Constant e o problema do arbítrio em um contexto de reação política}


Quando Benjamin Constant chega a Paris, em maio de 1795, em companhia de Madame de Staël, o projeto político de Roederer e Lezay-Marnésia era um dos mais influentes no meio republicano. Este capítulo propõe compreender suas intervenções políticas durante o Primeiro Diretório (1795-1797) em diálogo crítico com a corrente de pensamento aqui chamada de "liberalismo da ordem". Embora Constant seja mais conhecido por sua oposição à contrarrevolução e por sua crítica do jacobinismo, sustentaremos aqui que Roederer e Lezay-Marnésia eram adversários visados mais imediatamente, em decorrência de sua proximidade política e mesmo pessoal. ${ }^{35}$ Apesar da semelhança de objetivos políticos, os textos de Constant sob o Primeiro Diretório serão lidos aqui como uma resposta à crença de Roederer e Lezay-Marnésia segundo a qual a Revolução Francesa já terminou. Nessa contestação de Roederer e Lezay-Marnésia, o arbítrio emerge como um verdadeiro problema a assombrar o governo republicano ainda em vias de consolidação.

A primeira intervenção política de Constant incide justamente sobre a questão a respeito da qual acabamos de ver Roederer se pronunciar: os decretos dos dois terços. Esse início da carreira política e intelectual do autor é marcado por uma das primeiras reviravoltas que se associarão indelevelmente a sua imagem pública. Nas "Trois lettres à un député à la Convention", publicadas anonimamente nas Nouvelles politiques nationales et étrangères de 6, 7 e 8 Messidor do Ano III (24 a 26 de junho de 1795),

${ }^{35}$ Roederer, em particular, era próximo de Madame de Staël, a amante de Constant que o introduz nos círculos políticos e intelectuais parisienses. Em 1797, Staël escreve a Roederer que ela o considera “o pensador mais profundo que conheço” (STAËL apud ROEDERER, 1853-1859, vol. 8, p. 655), e que “jamais eu desviarei da linha que você me parece seguir mais exatamente do que qualquer outro" (STAËL apud ROEDERER, 1853-1859, vol. 8, p. 656). É ela que pede a Roederer uma resenha de Des réactions politiques de Constant (STAËL apud ROEDERER, 1853-1859, vol. 8, p. 653-654), mas o autor a contraria, publicando uma resenha negativa (ROEDERER, 1796-1797, tomo III, p. 301-312). Apesar de alguns elogios pontuais e de algumas resenhas positivas (principalmente da brochura Des suites de la contrerévolution de 1660 en Angleterre, no Journal de Paris de 24 e 27 Messidor do Ano VII, ou 12 e 15 de julho de 1799), as resenhas agressivas dos textos de Constant publicadas por Roederer sob o Diretório indicam uma verdadeira rivalidade política e intelectual no interior do centro republicano - uma rivalidade ainda pouco compreendida pelos estudiosos do período. Espera-se que este capítulo possa contribuir para uma maior compreensão dessa rivalidade. A posição particular de Staël no embate entre Constant e o liberalismo da ordem, do qual ela era próxima, será tratada no Capítulo 2 desta tese, no qual será analisado seu texto Des circonstances actuelles qui peuvent terminer la Révolution et des principes qui doivent fonder la République en France (1798). 
Constant critica enfaticamente a intenção, anunciada por Boissy d'Anglas, de obrigar, em nome da "salvação do Estado" (cf. CONSTANT, 1998a, p. 273, nota 2), as próximas assembleias eleitorais a conservar pelo menos metade dos membros da Convenção (intenção colocada em prática oficialmente por meio dos decretos de 5 e 13 Frutidor do Ano III já mencionados, os quais ampliam para dois terços o número de convencionais a conservar nos Conselhos). Dois meses depois, o autor muda de posição e passa a colaborar com o convencional e ex-girondino Jean-Baptiste Louvet na redação de três discursos favoráveis não apenas ao decreto dos dois terços já assegurado, mas também ao direito de a própria Convenção escolher qual seria o terço da assembleia a se retirar. ${ }^{36}$

Os comentadores explicam essa mudança de posição à luz das circunstâncias políticas e da percepção de Constant segundo a qual ele havia cometido um erro tático ao atacar a Convenção. ${ }^{37}$ Imediatamente após a redação das três cartas, o desembarque dos emigrados em Quiberon reacende o medo da contrarrevolução. Além disso, o jovem republicano recém-chegado a Paris se inquieta com a recepção desfavorável de suas cartas no campo republicano, e principalmente com a recepção entusiástica dessas cartas no campo monarquista, Constant chegando a ser convidado por um comitê de escritores a cooperar com eles para a restauração da monarquia. ${ }^{38}$ Perante essa conjuntura, é fácil explicar seu recuo e sua decisão de apoiar uma Convenção que se sentia ameaçada pela contrarrevolução. Contudo, propomos ir além dessa explicação já estabelecida e interpretar os dois meses que separam as três cartas dos discursos de Louvet como o momento crucial no qual Constant se afasta definitivamente do liberalismo da ordem de Roederer e Lezay-Marnésia, passando a enxergar a Revolução Francesa como ainda não concluída. É a partir desse momento crucial, situado no início da carreira política e intelectual do autor, que o problema do arbítrio se impõe a ele de modo incontornável, permanecendo como um problema central ao longo de todo o restante de sua vida.

${ }^{36}$ Esses discursos foram pronunciados por Louvet na Convenção, nos dias 3 e 4 Frutidor do Ano III (20 e 21 de agosto de 1795).

37 Ver a Introdução de Mauro Barberis às "Trois lettres" e aos "Discours de Louvet", em CONSTANT, 1998a. Ver também TODOROV, 1997, p. 77.

38 “(...) um comitê de escritores me enviou alguém para me felicitar e me convidar para cooperar com eles para o restabelecimento da realeza. Esse convite me fez explodir de surpresa e indignação. Voltei para casa amaldiçoando os salões, as mulheres, os jornalistas e tudo o que não quisesse a República para toda a eternidade" (CONSTANT, 2005b, p. 583). 
Com efeito, é notável a proximidade das "Trois lettres" com a linha de raciocínio seguida por Roederer e Lezay-Marnésia na mesma época (particularmente com o texto de Roederer sobre os decretos dos dois terços discutido no fim da seção anterior). Como eles, o jovem Constant nega que o voto popular possa trazer de volta a monarquia ou o Terror, argumentando que o desejo geral do povo é o estabelecimento da ordem: "a nação está cansada de agitações, (...) ela declara de modo quase unânime não querer mais nem revolução nem contrarrevolução" (CONSTANT, 1998a, p. 279). O argumento dos partidários dos decretos dos dois terços, segundo o qual a Constituição de 1791 foi derrubada porque seus autores foram excluídos da Assembleia Legislativa, leva Constant a responder com uma comparação entre 1791 e 1795, a qual lembra em muitos aspectos as fases da Revolução Francesa distinguidas mais tarde por Lezay-Marnésia. Se, em 1791, a paixão dominante era a liberdade, em 1795, o desejo geral é de ordem:

\footnotetext{
Vocês não veem que as circunstâncias atuais são exatamente o contrário daquelas de 1791? Que, então, a nação, embriagada por uma revolução que nenhum horror havia ainda maculado, possuía o sentimento da força e a lembrança do despotismo? Que, hoje, ela tem a recordação da anarquia e o sentimento de esgotamento? (...). Que a ideia então despertada pela palavra rei é despertada hoje pela palavra jacobino? Que a fuga de Varennes havia sido o que é hoje o $1^{\circ}$ Prairial? Assim, o próprio exemplo de 1791 contém um presságio favorável para o momento atual. Em 1791, a Constituição marchava contra o desejo, as opiniões e as inquietações da multidão. Hoje, aquela que vocês propuserem, qualquer que seja ela, se ela for repressiva e protetora, não poderá deixar de obter o assentimento universal. Em 1791, o povo só queria a liberdade; davam-lhe a ordem. Hoje, ele quer a ordem; só cabe a vocês entregála (CONSTANT, 1998a, p. 280-281; ênfases do autor).
}

O desejo geral de ordem é interpretado pelo jovem Constant, como por Roederer e Lezay-Marnésia, como a garantia principal que impede definitivamente o retorno de um poder arbitrário:

Em um povo disposto de tal modo, não há nada a se temer em relação aos espíritos inquietos. Mesmo que toda a próxima legislatura fosse composta por homens ardentes, e eu já disse que a opinião pública que presidirá às eleições torna essa hipótese completamente absurda, o cansaço nacional pesaria sobre ele e os conteria (CONSTANT, 1998a, p. 281).

Ora, é justamente dessa base do liberalismo da ordem que Constant se afastará nas semanas seguintes às três cartas, marcadas pela repercussão do desembarque de Quiberon. Pouco depois (em julho de 1795), ele escreve um artigo contra os emigrados no Républicain français, o qual é considerado por Mauro Barberis como uma espécie de ponto de transição entre o Constant das três cartas e o "republicano radical" que ele se tornará em seguida, aproximando-se primeiro de Louvet, depois de Paul Barras e Sieyès (BARBERIS, 1998b, p. 293). Com efeito, nota-se, nesse artigo ao Républicain français, 
uma crítica às "almas egoístas e tímidas que demandam apenas o repouso" (CONSTANT, 1998a, p. 295). A valorização excessiva da ordem e do repouso é rejeitada como mais própria aos monarquistas do que aos republicanos, e a liberdade republicana se torna o valor central de Constant, no lugar da ordem. ${ }^{39}$

Esta tese propõe compreender a reviravolta de Constant a respeito dos decretos dos dois terços à luz dessa passagem do liberalismo da ordem ao republicanismo radical. Com essa passagem, a ordem deixa de ser o valor central, e não há mais a suposição de uma nação guiada pelo desejo de ordem. Pelo contrário, o valor central passa a ser a República e a liberdade indissociável desse regime: "só existe agora um meio de salvação para todo cidadão: o estabelecimento da República" (CONSTANT, 1998a, p. 314). ${ }^{40}$ Consequentemente, o autor se dispõe a apoiar as ações da República que têm por finalidade se proteger de um eleitorado perigoso, cuja tendência a apoiar o regime republicano graças ao desejo de ordem não é mais tida por assegurada. Nos discursos escritos em colaboração com Louvet, é assinalado o perigo de submeter a sorte dos fundadores da República, ainda necessários para a consolidação desse regime, ao sufrágio de assembleias eleitorais dominadas por um "novo terrorismo" de tendência monarquista (CONSTANT, 1998a, p. 314-315).

Emerge, desse modo, o problema do arbítrio, o qual não cessará de assombrar Constant ao longo de sua vida. Com sua mudança de posição sobre os decretos dos dois terços, ele se confronta pela primeira vez com o problema dos meios arbitrários utilizados para salvar a República de si mesma. É verdade que a caracterização dos decretos dos dois terços como um ato arbitrário permanece controversa ainda hoje. Segundo Troper, "independentemente dos motivos mais ou menos puros que animavam os convencionais, os decretos dos dois terços não são desprovidos de fundamento lógico" (TROPER, 2006,

\footnotetext{
${ }^{39}$ Segundo Barberis, "o ataque contra os que colocavam o repouso antes da liberdade era um tópos da propaganda revolucionária da época” (cf. CONSTANT, 1998a, p. 295, nota 3). É possível fazer uma aproximação com a tese de Jainchill (2008), que se refere ao republicanismo clássico como a linguagem dominante do Diretório, e compreender esse momento da carreira de Constant como um alinhamento a essa linguagem dominante. Pode-se compreender a partir disso a origem de sua divergência em relação a Roederer, compreendida por Jainchill como uma disputa entre o "autoritarismo liberal", dominante no Consulado, e o "republicanismo liberal", que recebe uma impulsão da dissidência liberal contra Bonaparte. Ver o Capítulo 2 desta tese.

${ }^{40}$ Ou ainda: "Sim, os conspiradores mais audaciosos, assim como os cidadãos mais pacíficos, têm apenas um meio de salvação: a salvação da República” (CONSTANT, 1998a, p. 315).
} 
p. 87). Como a Constituição de 1795 estabelece a renovação do corpo legislativo por terços, uma eleição para escolher de uma única vez todo o corpo legislativo seria contrária à lógica estabelecida pela Constituição - de onde a ideia de manter dois terços da Convenção que chegava ao fim no novo corpo legislativo, uma proposição que, além disso, foi aprovada por referendo juntamente com a nova Constituição. ${ }^{41}$ Entretanto, como esclarece Mona Ozouf, o debate sobre os decretos fez reviver "o confronto entre a liberdade e a salvação pública" (OZOUF, 1996, p. 208), pois seus partidários defenderam a limitação da liberdade eleitoral com uma linguagem da salvação pública emprestada dos jacobinos. E foi justamente entre a liberdade total da eleição e o argumento da salvação da República que Constant oscilou, sua mudança de posição se devendo a um afastamento em relação à visão da Revolução Francesa como concluída pelo desejo geral de ordem, e não a uma mudança de interpretação da Constituição.

O que levantava o problema do arbítrio era a confrontação entre o imperativo de independência da República em relação à maioria nacional e o princípio da soberania do povo. Esses dois imperativos eram uma consequência do republicanismo de Constant, mas o primeiro derivava imediatamente de seu republicanismo "radical", em ruptura com o liberalismo da ordem, após o desembarque de Quiberon. Essa confrontação será visível em suas duas principais brochuras do período diretorial, De la force du gouvernement actuel de la France et de la nécessité de s'y rallier, de 1796, e Des réactions politiques, de 1797.

Eu desejo ardentemente ver se terminar a Revolução, porque, a partir de agora, ela só seria funesta para a liberdade. E é uma de minhas razões para desejar ardentemente também a consolidação da República, à qual, além disso, pareceme ligado tudo o que há de nobre e grande nos destinos humanos (CONSTANT, 1998a, p. 328).

Eis os objetivos declarados da brochura De la force du gouvernement. A fim de unir os franceses a essa República nascente, Constant se propõe a "provar que o Governo é forte por si mesmo, que ele não pode nunca ser atacado com vantagem” (CONSTANT, 1998a, p. 337). A primeira vantagem do governo republicano é, segundo o autor, o simples fato de ser o regime já estabelecido, de modo que uma "contrarrevolução não seria ela própria outra coisa do que uma nova revolução" (CONSTANT, 1998a, p. 338),

${ }^{41}$ É verdade que os decretos foram aprovados com apenas 200.000 votos, em uma votação marcada pela abstenção, ao passo que a Constituição de 1795 recebeu mais de 1.000.000 votos (GUENIFFEY, 2011, p. 356). 
tendo contra si todos os interesses ligados à atual ordem de coisas. Esse primeiro argumento de Constant sobre a força do governo republicano recebeu a famosa resposta de Joseph de Maistre, segundo a qual "o restabelecimento da monarquia, chamado de contrarrevolução, não seria uma revolução contrária, mas o contrário da revolução" (MAISTRE, 1988, p. 166; ênfases do autor). Todavia, esta tese se interessa mais pelo segundo argumento de Constant sobre a força do governo republicano, o qual é ligado mais diretamente a sua divergência com o liberalismo da ordem e ao problema do arbítrio:

\footnotetext{
Uma segunda vantagem do Governo atual é estar decidido a se sustentar. (...). Os indivíduos que o compõem estão ligados a sua obra por todos os interesses reunidos e, conferindo aos meios constitucionais e suaves uma justa preferência, eles nunca recusarão nenhum meio proporcional ao perigo (CONSTANT, 1998a, p. 340).
}

A ideia de uma preferência pelos "meios constitucionais e suaves", mas sem jamais recusar "nenhum meio proporcional ao perigo", já levanta o problema da possibilidade do arbítrio contra um perigo que ameaça a República - um problema ao qual Constant responderá, na Conclusão da brochura, com uma exortação contra o arbítrio. Porém, antes de confrontar diretamente a questão do arbítrio, o autor examina a possível contradição entre um governo decidido a se conservar e o princípio da soberania do povo, concebido como o fundamento da República. "Poderão tornar contra eles [os indivíduos que compõem o Governo] princípios abstratos e dizer que uma consequência da Soberania do Povo é que, a não ser que sua vontade esteja claramente exprimida, um Governo não tem o direito de defender sua existência" (CONSTANT, 1998a, p. 340). Constant associa rapidamente essa possível objeção às manipulações dos monarquistas:

\footnotetext{
Os mesmos homens que louvam, com razão, os governos estrangeiros por se oporem às Revoluções, as quais são sempre um grande mal, exigiriam de bom grado que o da França favorecesse sua derrubada, e que sua única ocupação fosse um recenseamento perpétuo das vozes, a favor ou contra a República (CONSTANT, 1998a, p. 340-341).
}

O autor responde com uma distinção entre justiça e imparcialidade, argumentando que "a Justiça é um dever para os governantes, mas a imparcialidade seria uma loucura e um crime. Para fazer uma instituição funcionar, é preciso um homem que seja parcial em favor da instituição" (CONSTANT, 1998a, p. 341). Essa defesa da parcialidade republicana dos governantes é uma defesa da independência do governo republicano em relação à maioria nacional - distinta da independência em relação ao Poder Legislativo, enfatizada por Roederer e Lezay-Marnésia. Respondendo às objeções derivadas do princípio da soberania do povo, Constant propõe interpretar o voto do povo segundo os grandes eventos da Revolução Francesa, não segundo os sufrágios ou opiniões 
momentâneos: “O povo se pronuncia por fatos. Em 14 de julho, ele se pronunciou pela liberdade. Em 10 de agosto, pela República. Em 9 Termidor e em 4 Prairial, contra a anarquia. Eis o seu voto" (CONSTANT, 1998a, p. 341).

Reside aqui a oposição principal entre De la force du gouvernement de Constant e o texto de Lezay-Marnésia já mencionado, De la faiblesse d'un gouvernement qui commence. ${ }^{42}$ Philippe Raynaud exprime assim essa oposição:

A verdadeira divergência entre Constant e ele (determinada, sem dúvida, pelo decreto dos dois terços) diz respeito à maneira de terminar a Revolução e de estabilizar a ordem social saída dela. Para Constant, a defesa dos interesses novos passa por certa autonomização do "Governo" em relação à sociedade e pela exigência de uma parcialidade do pessoal político a favor da República. Para Lezay, ao contrário, a ideia de representação das opiniões e dos interesses deve ser tomada ao pé da letra: o governo legítimo será aquele que expressa a maioria nacional, fundada sobre o sentimento geral e exprimida na opinião pública (RAYNAUD, 1988, p. 15; ênfases do autor).

Raynaud exprime bem a divergência entre o apelo de Constant por uma autonomização do governo republicano em relação à sociedade e o apelo contrário de Lezay-Marnésia por uma união entre o governo e a maioria nacional. Ele relaciona essa divergência à crença de Lezay-Marnésia, segundo a qual já haveria na França “um sistema político consolidado e aceitável para os diferentes interesses em presença, porque não se confunde com nenhum deles" (RAYNAUD, 1988, p. 18) - uma crença que Constant não compartilhava. Esta tese se propõe a ir além dessa análise de Raynaud, interpretando a divergência entre Constant e Lezay-Marnésia como o resultado de visões diferentes sobre as paixões dominantes na França pós-revolucionária. Em resumo, Constant contesta a teoria das três etapas da Revolução, caracterizadas respectivamente pelos desejos de liberdade, igualdade e ordem. Contra essa teoria, o jovem autor franco-suíço desenvolve

${ }^{42}$ Apesar da oposição sugerida pelos títulos, Roederer escreve, no Journal de Paris de 23 Prairial do Ano IV (11 de junho de 1796), que “as duas obras não têm nada de relativo uma à outra. A verdade é que Lezay não parece ter pensado em Constant enquanto escrevia, e parece que o próprio Constant não considerou mais o título de seu livro, nem seus primeiros capítulos, quando escreveu os últimos. Pois estes poderiam figurar muito bem na obra, ou pelo menos sob o título de Lezay” (ROEDERER, 1853-1859, vol. 5, p. 87). Essa citação de Roederer, geralmente pouco considerada pelos estudiosos, serve-nos de precaução contra a atitude precipitada, mas usual, de interpretar o texto de Lezay-Marnésia como uma resposta explícita ao de Constant. De todo modo, a rivalidade entre Constant e a dupla Roederer-Lezay-Marnésia não deixa de transparecer, Roederer se apressando em apontar contradições no texto de Constant. 
a das reações políticas, exposta no início de sua brochura seguinte, Des réactions politiques, de $1797 .{ }^{43}$

"Para que as instituições de um povo sejam estáveis, elas devem estar no mesmo nível de suas ideias” (CONSTANT, 1998a, p. 457), teoriza Constant, para explicar a eclosão das revoluções. "Quando o acordo entre as instituições e as ideias se encontra destruído, as revoluções são inevitáveis. Elas tendem a restabelecer esse acordo. Não é sempre esse o objetivo dos revolucionários, mas é sempre essa a tendência das revoluções" (CONSTANT, 1998a, p. 457). O repouso e a ordem, tão exaltados por Roederer e Lezay-Marnésia, não seriam mais do que um produto do restabelecimento do acordo entre as instituições e as ideias - um acordo que algumas revoluções felizes, como as da Suíça, da Holanda e dos Estados Unidos da América, conseguiram restabelecer de uma só vez, chegando ao repouso e à ordem imediatamente após a eclosão da revolução, sem precisar enfrentar nenhuma reação (CONSTANT, 1998a, p. 457). Infelizmente, algumas revoluções ultrapassam seu objetivo inicial, estabelecendo instituições que ainda não são reivindicadas pelas ideias dominantes no momento em questão, ou destruindo instituições que estavam ancoradas nessas ideias. Essas revoluções, que ultrapassam as ideias dominantes em radicalismo, produzem inevitavelmente reações políticas, as quais tornam o restabelecimento da ordem e do repouso mais difícil e menos automático:

A revolução da Inglaterra, que havia sido feita contra o Papismo, tendo
ultrapassado esse termo ao abolir a realeza, uma reação violenta teve lugar, e
foi necessária, vinte e oito anos depois, uma nova revolução para impedir o
Papismo de se restabelecer. A revolução da França, feita contra os privilégios,
tendo igualmente ultrapassado seu termo ao atacar a propriedade, uma reação
terrível se faz sentir, e serão necessários, não, eu espero, uma nova revolução,
mas grandes precauções e um cuidado extremo, para se opor ao renascimento
dos privilégios (CONSTANT, 1998a, p. 457-458). Segundo Constant, a radicalização da Revolução Francesa, a partir de 1793, não engendrou na sociedade um desejo geral de ordem que facilita a conclusão dessa revolução, como acreditam, na mesma época, Roederer e Lezay-Marnésia. Pelo contrário, o efeito dessa radicalização foi a difusão de um espírito de reação que impede a Revolução de terminar, uma vez que os republicanos se veem obrigados a retomar a luta contra instituições e ideias que pareciam definitivamente derrotadas. Esse espírito de reação se manifesta ao mesmo tempo contra os homens, na forma da tentativa de perseguir os

${ }^{43}$ Sobre o pioneirismo de Constant na elaboração de uma teoria coerente sobre as reações políticas, e para situar essa teoria no universo mais vasto das filosofias do progresso histórico dos séculos XVIII e XIX, ver: STAROBINSKI, 2000. 
revolucionários, e contra as ideias, na forma de uma reabilitação dos preconceitos e de uma rejeição dos princípios. No lugar do desejo geral de ordem imaginado por Roederer e Lezay-Marnésia, Constant vê uma profusão de discursos que visam a anular a obra da Revolução Francesa, fazendo a França retroceder para o absolutismo e os privilégios um retrocesso visto como incompatível com a ordem, pois ele engendraria inevitavelmente novas revoluções. Eis a razão por que Constant não prega, como LezayMarnésia, que o governo se guie pelo sentimento geral e pela opinião pública expressos pela maioria nacional. A sociologia de Roederer e Lezay-Marnésia, assim como sua teoria das três fases da Revolução, levavam-nos a assimilar o sentimento geral, a opinião pública e o desejo de ordem como sinônimos. Não é o caso de Constant, para quem o império do sentimento geral e da opinião pública, no contexto do Diretório, seria o império das paixões vingativas e das ideias de reação, ou antes da reação contra as ideias.

Interpretamos, portanto, a teoria das reações políticas de Constant como a causa principal de sua divergência com Roederer e Lezay-Marnésia, ao menos desde a reviravolta sobre os decretos dos dois terços. Essa teoria, aliás, não foi bem recebida por Roederer. Em sua resenha de Des réactions politiques, publicada no Journal d'économie publique, o jornalista acusa a teoria das reações políticas de Constant de contradição:

(...) desde o seu primeiro passo, ele se desvia de seu princípio. Pois, se o acordo entre as ideias e as instituições assegura a permanência destas últimas, esse acordo se encontra na abolição dos privilégios e no respeito das propriedades. Quando as propriedades foram atacadas, precisou haver uma reação contra as leis devastadoras e os homens devastadores. Foi o que aconteceu em 9 Termidor. Então, as ideias precisaram entrar em acordo com as instituições; assim, não deve mais haver reação (ROEDERER, 1796-1797, tomo III, p. $302)$.

Roederer chega a acusar Constant de atacar implicitamente a liberdade de imprensa, ao insinuar que os jornais estariam impregnados pela "reação contra as ideias" (ROEDERER, 1796-1797, tomo III, p. 305). Em resumo, aos olhos de Roederer e LezayMarnésia, a argumentação de Constant para demonstrar que a sociedade francesa estava dominada por um espírito de reação, e que era preciso um governo republicano forte e autônomo em relação a essa sociedade, parecia uma justificativa para o autoritarismo desse governo, pronto a perseguir jornalistas independentes como eles.

Com efeito, a teoria das reações políticas levantava o problema do arbítrio (e, portanto, do autoritarismo) de modo agudo. Em primeiro lugar, porque o arbítrio era concebido por Constant como um traço intrínseco à reação contra os homens: “O que (...) distingue essencialmente as reações é o arbítrio no lugar da lei” (CONSTANT, 1998a, p. 
458). Mas, sobretudo, porque Constant não parecia indicar claramente como combater o espírito de reação sem recorrer aos meios arbitrários (era a crítica de adversários como Roederer). Retornava-se, assim, à tensão entre a independência do governo republicano em relação à maioria nacional, justificada pela teoria das reações políticas, e o princípio da soberania do povo, concebido como o fundamento da República. Vimos Constant ironizar aqueles que queriam obrigar o governo republicano a fazer "um recenseamento perpétuo das vozes, a favor ou contra a República", como "o piloto hesitante que, ainda agitado por um mar tempestuoso, mas em frente ao porto, pergunta a sua equipe se, por acaso, ela não gostaria de recomeçar o trajeto" (CONSTANT, 1988, p. 42). Todavia, o princípio da soberania do povo, na versão representativa abraçada por Constant, obriga o povo a se pronunciar periodicamente para a eleição de representantes. No sistema representativo defendido pelo autor desde o início de sua carreira, o voto do povo não pode ser presumido somente com base em eventos como o 14 de julho, o 10 de agosto, o 9 Termidor, etc. E a teoria das reações políticas, que acabamos de analisar, levantava o risco de eleições que levariam ao poder inimigos da Revolução e da República. Constant acreditava na possibilidade de evitar esses resultados eleitorais catastróficos para a República sem recorrer aos meios arbitrários? E, em caso negativo, ele estava disposto a defender o arbítrio como meio de salvar a República em perigo? São questões que a teoria otimista de Roederer e Lezay sobre a conclusão da Revolução Francesa evitava, mas que se tornavam inevitáveis à luz da teoria das reações políticas de Constant, para quem a Revolução ainda não havia terminado.

Vimos Constant dizer, sobre os membros do Diretório, que, "conferindo aos meios constitucionais e suaves uma justa preferência, eles nunca recusarão nenhum meio proporcional ao perigo" (CONSTANT, 1998a, p. 340). Ou seja, nos casos em que a República estivesse em perigo e os meios legais fossem considerados como insuficientes, os membros atuais do governo não hesitariam em recorrer aos meios extralegais - em outras palavras, arbitrários. Já havia sido o caso, até certo ponto, dos decretos dos dois terços, na medida em que sua justificação havia sido a salvação da República, mais do que uma aplicação estrita da Constituição. Constant fornece, no Capítulo 2 de De la force du gouvernement, um exemplo ainda mais audacioso de "meio proporcional ao perigo" possivelmente utilizado pela República: o apelo aos terroristas, "essa artilharia do governo, sempre escondida, mas sempre temível, e que, todas as vezes em que ele se vir forçado a empregá-la, reduzirá a pó seus adversários” (CONSTANT, 1998a, p. 342). 
Segundo o autor, "essa nova raça” (CONSTANT, 1998a, p. 343) criada pela Revolução colocou "ao retorno da Realeza um obstáculo que ela nunca superará" (CONSTANT, 1998a, p. 343), mesmo se os resultados do possível emprego desses homens terríveis contra os monarquistas seriam, com certeza, catastróficos. Constant diz que seria melhor guardar silêncio sobre esse recurso secreto do governo republicano, "se, para a salvação pública, não fosse preciso lançar por uma vez um olhar fixo nessa direção" (CONSTANT, 1998a, p. 342). Trocando em miúdos, Constant não nega que o combate ao espírito de reação possa levar o governo republicano a recorrer a meios arbitrários. Ele chega a afirmar que a possibilidade dessas medidas arbitrárias constitui a garantia final da duração desse governo, dado que, se houver necessidade do arbítrio, ele poderá contar com a "artilharia escondida" dos terroristas.

A consideração da possibilidade de uma ação arbitrária do governo republicano, com o objetivo de conter o espírito de reação, faz o arbítrio emergir como um problema teórico agudo no pensamento de Constant. Sua teoria das reações políticas o obriga a fornecer uma resposta ao problema de qual deve ser a ação do governo republicano quando ele se sente inclinado a se proteger da contrarrevolução por meios arbitrários. Como vimos, os revolucionários franceses haviam respondido a essa questão por meio do artifício do estado de exceção, na forma dos casos de "ditadura comissarial" previstos na Constituição de 1791, ou da "ditadura soberana" que se afirma com o governo revolucionário de 1793-1794. Roederer e Lezay-Marnésia, por sua vez, haviam obliterado o problema, considerando a possibilidade do arbítrio como deslocada no contexto póstermidoriano.

A resposta de Constant contrasta com as que haviam sido formuladas antes dele. Ela é dada no Capítulo VIII (Conclusão) de De la force du gouvernement, e no Capítulo IX ("De l'arbitraire") de Des réactions politiques. Ela vem quando o autor cessa de falar aos franceses sobre a necessidade de apoiar o governo republicano e passa a se dirigir "ao próprio governo e aos escritores que o defendem" (CONSTANT, 1998a, p. 376). Se, na mensagem aos franceses, o arbítrio havia aparecido como uma possibilidade que, embora terrível, assegurava em último caso a força e a duração do governo republicano, quando Constant se dirige ao governo, a tentação do arbítrio se torna mais perigosa do que a ameaça contrarrevolucionária. O autor alerta o governo de que "o perigo mais iminente que o ameaça não vem de seus inimigos; ele vem de certos hábitos revolucionários, que são a inversão de todos os princípios, a perversão de todas as opiniões" (CONSTANT, 
1998a, p. 376). Constant não lamenta tanto o emprego desses "hábitos revolucionários" pelos jacobinos, pois ele está certo de que o povo os via como simples criminosos, de modo que seu sistema de terror não corrompia a opinião popular. Mais grave, a seus olhos, foi a perseguição arbitrária dos terroristas pelos termidorianos (cf. BACZKO, 1989a), pois esse emprego "honesto" do arbítrio "corrompeu a opinião em sua fonte. Consagraram a ilegalidade ao fazê-la servir ao bem. (...) por uma enganosa experiência, provaram que o arbítiro podia ser útil" (CONSTANT, 1998a, p. 376). O autor começa, então, sua célebre exortação contra a violação das formas legais pelos homens honestos, mesmo quando essa violação tem por objetivo o bem público e a punição dos celerados. Isso seria pior do que a violação das formas legais pelos celerados contra os homens honestos, pois o primeiro caso habituaria o povo a ver as formas como obstáculos à justiça, ao passo que

(...) no corpo político, apenas as formas são estáveis e podem resistir aos homens. O fundo mesmo, ou seja, a justiça, a virtude, podem ser desfiguradas. Seus nomes estão à mercê de quem quiser empregá-los. Robespierre pode invocar a pátria, a liberdade, a moral, como Lanjuinais (CONSTANT, 1998a, p. 377).

Assim, a primeira resposta de Constant à possibilidade do arbítrio, por parte do governo republicano, é sua rejeição completa. $\mathrm{O}$ autor se compromete com uma cultura da sacralidade das formas legais, rejeitando a superioridade de valores substantivos como a justiça, a virtude, a salvação pública, etc. Afinal, como demonstrou a experiência do Terror, todos esses valores poderiam ser deturpados sem dificuldade. O liberalismo esboçado por Constant desde esse momento é, portanto, muito distante do de Locke, com a prioridade do Salus populi suprema lex discutida na Seção 1.1.

Resulta disso o projeto de extirpação absoluta do arbítrio, este sendo visto como a paixão comum a todos os partidos em disputa:

(...) um traço distintivo do caráter e da opinião do momento, um traço comum
a todos os partidos, é que não se odeia o arbítrio em si mesmo, a primeira coisa
que seria preciso odiar em um país livre, mas somente tal ou tal arbítrio, que
contraria nossas impulsões ou nossos interesses (CONSTANT, 1998a, p. 377).

Assim como os valores substantivos, as circunstâncias são rejeitadas como uma possível justificação para o arbítrio: "Se não se tomar cuidado, haverá sempre circunstâncias a invocar contra os princípios" (CONSTANT, 1998a, p. 377). Ou seja, a ideia de um estado de exceção justificado por circunstâncias extraordinárias, tão em voga durante a Revolução Francesa, é igualmente rejeitada por Constant para servir de justificação às medidas arbitrárias. 
O autor não emprega apenas argumentos morais contra o arbítrio. Ele sustenta que o modo de proceder oposto ao arbítrio, aquele ancorado na lei e nos princípios, é mais conforme ao verdadeiro interesse do governo, mesmo quando isso contraria as aparências, pois um governo só encontra estabilidade no respeito escrupuloso da lei:

Em tudo o que a salvação pública exige, há duas maneiras de proceder, uma
legal, e a outra arbitrária. No longo prazo, é sempre com a primeira, mesmo
quando ela é mais lenta, que o governo se encontra melhor. Somente ela pode
lhe conferir uma dignidade e uma força duráveis (CONSTANT, 1998a, p. 377-
378).

Essa condenação implacável do arbítrio, efetuada na Conclusão de De la force du gouvernement, é retomada no Capítulo IX de Des réactions politiques, intitulado justamente "De l'arbitraire". É nele que Constant formula a definição de arbítrio já referida na Introdução desta tese: o arbítrio como "a ausência de regras, de limites, de definições, em suma, a ausência de tudo o que é preciso" (CONSTANT, 1998a, p. 496; cf. p. 21 supra). Tratava-se de uma operação teórica e retórica ousada, pela qual o arbítrio deixava de ser um simples sinônimo de governo absoluto e ilimitado, tornando-se o antípoda dos princípios - o objeto do Capítulo VIII de Des réactions politiques ("Des principes"). ${ }^{44}$

Definir o arbítrio como a negação dos princípios, e definir os princípios como "o resultado geral de certo número de fatos particulares" (CONSTANT, 1998a, p. 490), era, para Constant, como vimos na Introdução, uma forma de se contrapor à acusação de Burke, ecoada pelo "espírito de reação” em voga no início do Diretório, segundo a qual os princípios revolucionários eram meras abstrações metafísicas sonhadas por filósofos irresponsáveis, cuja tentativa de aplicação ao mundo real não poderia ter outro resultado além da violência. Como também visto na Introdução, Constant procurava se distinguir também de Kant, visto como um filósofo que ocupava o polo oposto ao de Burke, instituindo princípios tão inflexíveis que eles se tornavam impraticáveis nas circunstâncias particulares. A solução do autor franco-suíço, para aplicar os princípios universais aos fatos particulares sem incorrer nas aporias em que cai Kant - quem chega a proibir a mentira a um assassino que pergunta se a vítima que ele procura está escondida

${ }^{44}$ Assim, divergimos de Starobinski, para quem "pelo nome de arbítrio, Constant designa toda forma de absolutismo, a começar pelo do Terror" (STAROBINSKI, 2000, p. 48). Em nossa leitura, Constant confere ao arbítrio um significado mais geral do que o de absolutismo. É verdade que ele chega a sugerir, como veremos, que há um caminho necessário que leva da transgressão pontual dos princípios ao absolutismo e ao terror. 
em sua casa -, consiste na noção de princípios intermediários ou secundários, os quais oferecem a mediação necessária entre o princípio universal e o caso particular. Kant chegou a responder a Constant, acusando-o de romper a universalidade dos princípios ao sugerir uma exceção ao dever moral de dizer a verdade (KANT, 1967, p. 73). No entanto, apesar da crítica de Constant à tendência de Kant a aplicar os princípios universais às circunstâncias particulares sem as mediações necessárias, seu objetivo era, como o filósofo alemão, um mundo moral e político regido completamente por princípios universais. Um objetivo que se ligava ao projeto de extirpação completa do arbítrio, visto não apenas como o signo de um governo absoluto, mas como o traço de qualquer ação impossível de teorizar ou de remeter a princípios fixos: "O arbítrio é, portanto, o grande inimigo de toda liberdade, o vício corruptor de toda instituição, o germe de morte que não se pode modificar, nem mitigar, mas que é preciso destruir" (CONSTANT, 1998a, p. 502; ênfase nossa). $\mathrm{O}$ arbítrio precisaria ser eliminado da ordem política porque ele passa rápida e quase inevitavelmente da aplicação pontual ao despotismo e ao Terror, definido como “o arbítrio levado ao extremo" (CONSTANT, 1998a, p. 500):

Ora, pela natureza do arbítrio, não se pode nunca estar certo de que ele não será levado ao extremo. É mesmo indubitável que ele se encaminhará nessa direção, todas as vezes em que for atacado. Pois uma coisa sem limites, defendida por meios sem limites, não é suscetível de limitação. O arbítrio, combatendo pelo arbítrio, deve se liberar de toda barreira, esmagar todo obstáculo, produzir, em uma palavra, o que era o Terror (CONSTANT, 1998a, p. 500).

Assim, nada seria mais difícil do que frear o arbítrio uma vez que ele é posto em marcha, mesmo que de modo pontual: "Nada é mais comum do que mudar de arbítrio; nada é mais raro do que passar do arbítrio à lei” (CONSTANT, 1998a, p. 501). Para realizar essa passagem do arbítrio à lei, ou do governo revolucionário ao governo constitucional, haveria a necessidade urgente "de princípios positivos, de leis claras e precisas, em resumo, de instituições a tal ponto fixas, que elas não deixam à tirania nenhuma entrada, à invasão nenhum pretexto" (CONSTANT, 1998a, p. 501).

Como avaliar essa resposta de Constant ao problema do arbítrio - levantado, como vimos, pela tensão, presente em seus escritos, entre a soberania do povo e a independência do governo republicano em relação à maioria nacional? Até certo ponto, a condenação de Constant ao arbítrio, sua oposição entre o arbítrio e o império da lei e dos princípios e sua associação entre o arbítrio e o Terror não o afastavam muito de um tópos já consagrado na elite política termidoriana, o qual tinha por alvo principal os jacobinos. O próprio Roederer já havia se feito um campeão desse tópos anti-arbítrio, em discursos escritos por 
ele e lidos por Jean-Lambert Tallien na Convenção, após a queda de Robespierre. No primeiro desses discursos, de 11 Frutidor do Ano II (28 de agosto de 1794) - "um dos primeiros de muitos esforços para caracterizar e explicar o Terror como um sistema de governo e uma fase distinta da Revolução Francesa" (BAKER, 1994, p. xiv) -, o arbítrio é erigido em categoria central da definição do Terror: "o sistema do terror supõe o exercício de um PODER ARBITRÁRIO por parte daqueles que se encarregam de difundi-lo" (ROEDERER, 1853-1859, vol. 7, p. 7). Há o mesmo raciocínio apresentado mais tarde por Constant, segundo o qual o arbítrio leva ao poder absoluto, entendido como "aquele que não deve obediência nem presta contas a ninguém, e que exige obediência de todo o mundo" (ROEDERER, 1853-1859, vol. 7, p. 7). O arbítrio sendo definido, como por Constant, como a ausência completa de regras e de limites, ele leva ao absolutismo porque um poder que julga e condena sem regras não poderia obedecer nem prestar contas a ninguém: "como exercer o poder arbitrário se fosse preciso prestar contas do uso que se faz dele? Seríamos submetidos nós mesmos a um julgamento arbitrário, pois não poderíamos ser julgados segundo regras, não tendo sido submetidos a nenhuma" (ROEDERER, 1853-1859, vol. 7, p. 7). Portanto, Roederer já havia estabelecido pela boca de Tallien, antes de Constant, o caminho que leva do arbítrio ao poder absoluto e ao Terror.

O mesmo caminho é traçado com ainda mais precisão em outro discurso que Roederer prepara para Tallien em 1795, "De la Terreur". A ruptura do governo com as regras da justiça e a permissão de "um livre curso ao arbítrio" (ROEDERER, 1853-1859, vol. 3, p. 60) são apresentadas como a condição principal do Terror, o arbítrio sendo caracterizado pela "faculdade de confundir o inocente com o culpado" (ROEDERER, 1853-1859, vol. 3, p. 61). Nesses discursos escritos por Roederer e lidos por Tallien, muitas considerações que Constant fará sobre o arbítrio e o Terror são adiantadas: a segurança dos culpados e a insegurança dos inocentes e dos amigos da República sob o reino do arbítrio terrorista; a refutação da tese segundo a qual o Terror era necessário para vencer os inimigos da República; a condenação arbitrária inevitavelmente aplicada aos que haviam governado arbitrariamente.

Desse modo, o discurso de Constant sobre o arbítrio, durante o Diretório, não era tão distante do já presente no "liberalismo da ordem" de Roederer. Há, contudo, diferenças a serem observadas no contexto e no sentido dos dois discursos. Os de Roederer e Tallien pertenciam ao período termidoriano pré-diretorial. Robespierre já 
havia sido derrubado, mas o governo revolucionário ainda estava em vigor, e o poder absoluto da Convenção ainda não havia sido substituído por uma nova ordem constitucional com uma divisão dos poderes. Nesse contexto, a condenação do arbítrio terrorista tinha por objetivo apressar a instituição da nova ordem constitucional. É esse, pelo menos, o objetivo confessado por Roederer na Advertência à republicação de seu discurso em 1815, na qual ele se vangloria de ter sido bem-sucedido nesse objetivo: "Posso acreditar, sem me vangloriar demais, que ele [o discurso "De la Terreur"] contribuiu para a derrubada do Comitê de Salvação Pública e o retorno das leis" (ROEDERER, 1853-1859, vol. 3, p. 58). ${ }^{45}$ A intenção desses discursos termidorianos contra o arbítrio terrorista era, assim, a passagem da segunda etapa da Revolução, dominada pela paixão pela igualdade e pela necessidade do arbítrio, à terceira fase da Revolução, na qual a paixão dominante pela ordem tornaria o arbítrio deslocado. Como vimos na Seção 1.2, o liberalismo da ordem de Roederer e Lezay-Marnésia faz o arbítrio desaparecer como problema no fim das revoluções populares, marcado pelo desejo geral de ordem.

Nos escritos de Constant, ao contrário, a teoria das reações políticas fazia o arbítrio emergir como um problema central não somente em relação ao Terror jacobino já derrubado, mas, sobretudo, em relação às opções colocadas ao governo diretorial em sua luta contra o espírito de reação. Sua originalidade não estava na simples condenação do arbítrio, o que era uma espécie de lugar comum no contexto pós-termidoriano, mas na percepção do arbítrio como um problema político que continuava premente mesmo após a derrocada do Terror. No difícil equilíbrio entre a soberania do povo e a independência do governo em relação à maioria nacional, o recurso, mesmo pontual, às medidas arbitrárias parecia se insinuar ao governo como a única maneira de manter sua independência perante o espírito de reação. O próprio Constant havia insinuado a possibilidade desse recurso ao arbítrio em casos de perigo para a República, notadamente em sua defesa dos decretos dos dois terços, reiterada no Capítulo 2 de De la force $d u$ gouvernement (CONSTANT, 1998a, p. 341), e na possibilidade de "apelo aos terroristas" já discutida. Desse modo, o tópos do arbítrio não era, para ele, apenas uma maneira de

\footnotetext{
${ }^{45}$ No contexto em que foram pronunciados, os discursos de Roederer e Tallien visavam ainda mais imediatamente à punição dos responsáveis pelo Terror, excluindo, é claro, o próprio Tallien, que se escondia atrás de seu discurso exaltado contra o sistema do Terror (BACZKO, 1989b, p. 143). Sobre o contexto geral desses discursos, ver: BACZKO, 1989a.
} 
anatematizar o governo jacobino já derrubado, mas, sobretudo, uma maneira de advertir o governo diretorial sobre os perigos das opções colocadas sobre a mesa. Na hipótese aqui desenvolvida, é a própria possibilidade do arbítrio, sugerida pela tensão entre a soberania do povo e a independência do governo republicano em relação à maioria nacional em um contexto de reação política, que leva Constant a desenvolver sua condenação implacável do arbítrio. Sem essa condenação explícita, seus escritos diretoriais poderiam ser percebidos como exortações à tirania, ou mesmo convencer o Diretório a adotar medidas perigosas. Em resumo, é o reconhecimento da possibilidade do arbítrio que leva Constant a condená-lo sem apelo nem agravo.

Essas diferenças de contexto e de sentido entre os discursos de Roederer e de Constant sobre o arbítrio explicam bem as divergências entre eles - um pouco enigmáticas se elas não são situadas desse modo. Em sua resenha de Des réactions politiques, Roederer elogia os capítulos de Constant sobre o arbítrio - ou seja, o Capítulo VIII (Conclusão) de De la force du gouvernement e o Capítulo IX ("De l'arbitraire") de Des réactions politiques. Ele chega a escrever, ironicamente, que "Benjamin Constant é tão feliz em seus últimos capítulos que seus amigos deveriam lhe aconselhar a nunca escrever outros" (ROEDERER, 1796-1797, tomo III, p. 310). É que a condenação do arbítrio e a exposição de seus perigos faziam referência ao tópos antijacobino que o próprio Roederer já havia explorado em seus discursos lidos por Tallien. Por outro lado, o que Roederer critica com veemência, em Des réactions politiques, são as oportunidades que Constant teria aberto para o arbítrio. Ele começa sua resenha lembrando a advertência, lançada em De la force du gouvernement, segundo a qual "os terroristas eram o corpo de reserva do governo e jamais lhe faltariam na ocasião” (ROEDERER, 1796-1797, tomo III, p. 301), observando em seguida, com sarcasmo, que "Babeuf se encarregou, pouco tempo depois, de refutar Benjamin Constant, e sua obra perdeu muito com a descoberta da conjuração" (ROEDERER, 1796-1797, tomo III, p. 301). Após sugerir essa cumplicidade decepcionante de Constant com a extrema esquerda terrorista, Roederer o acusa de mobilizar o tema da "reação contra as ideias" com o objetivo de atacar a liberdade de imprensa (ROEDERER, 1796-1797, tomo III, p. 305). Enfim, o editor do Journal d'économie publique contesta a noção de princípios desenvolvida por Constant, fazendo a esse respeito uma crítica similar à de Kant. Segundo ele, definir um princípio como "o resultado geral de certo número de fatos particulares", como o faz Constant, "é mais ou menos como se disséssemos que os efeitos são causas. A palavra princípio, principium, 
se explica por si mesma. É o começo, o antecedente de toda ação razoável" (ROEDERER, 1796-1797, tome III, p. 307). A teoria constantiana dos princípios intermediários, mobilizados para aplicar os princípios universais às circunstâncias particulares, parece a Roederer, como a Kant, uma maneira de se subtrair à aplicação rigorosa dos princípios universais:

Responderei a Benjamin Constant que não há circunstâncias às quais não se aplicam os princípios de justiça, de moral, de humanidade, e que aqueles que os acham inaplicáveis são os que procuram se furtar a eles. Os princípios estão sem cessar em oposição às paixões. O que buscamos é a arte de as eludir.

Assim, aos olhos de Roederer, Constant era um autor que abria portas demais ao arbítrio, apesar da condenação deste nos "últimos capítulos", mais felizes do que a totalidade de seus livros. O império dos princípios pregado pelo autor de Des réactions politiques seria apenas uma ascendência fraca. A causa é que, para Constant, o arbítrio era um problema, o que não era o caso para Roederer. Para este, a Revolução Francesa já havia terminado, a paixão dominante era o desejo de ordem, e "os princípios livrados das paixões" (ROEDERER, 1796-1797, tomo III, p. 309) poderiam retomar sua ascendência completa. O princípio da soberania do povo não colocava, para ele, o problema do arbítrio, pois sua tradução sociológica era o império da opinião pública formulada pela classe proprietária e ilustrada, dominada pelo desejo de ordem e de tranquilidade. A independência do governo tampouco levantava o problema do arbítrio, pois, como vimos, Roederer compreendia essa independência como a do Poder Executivo em relação ao Legislativo (não como uma independência em relação aos votos da maioria nacional, como Constant), e ele pensava que o Executivo não poderia agir arbitrariamente sem se ver ameaçado por um Legislativo invasor. A Revolução concluída, o arbítrio poderia, assim, ser totalmente evitado por uma boa Constituição que assegurasse ao Poder Executivo o lugar que lhe é devido.

Em resumo, Constant e Roederer não divergiam sobre a visão negativa do arbítrio, presente em ambos os autores, mas antes sobre sua possibilidade no contexto diretorial. Para Roederer, o arbítrio era a marca de uma página já virada da Revolução Francesa. Para Constant, o arbítrio era uma possibilidade que se tornava aguda em decorrência da tensão entre o princípio da soberania do povo e o imperativo de independência do governo republicano em relação à maioria nacional, em um contexto de reação política. Era essa possibilidade que o levava a, por precaução, condenar implacavelmente o arbítrio. 


\subsection{Uma controvérsia sobre o Terror}

Para terminar este capítulo, propomos interpretar o debate travado entre Constant e Lezay-Marnésia sobre o Terror, na primavera de 1797, à luz desse problema do arbítrio que opunha Constant ao liberalismo da ordem. Em 1797, Lezay-Marnésia publica Des causes de la Révolution et de ses résultats, um dos primeiros balanços do conjunto da Revolução Francesa, procurando ponderar suas causas, seu percurso e seus resultados. Trata-se da apreensão mais acabada da Revolução Francesa, do ponto de vista do

liberalismo da ordem. É verdade que, considerando-se Necker como um dos articuladores pioneiros das preocupações características do liberalismo da ordem, deve-se fazer menção a sua grande obra de 1796, De la Révolution française (NECKER, 1797). Não obstante, Necker é, nesse momento, um crítico e um adversário da Revolução Francesa. Consequentemente, ele elabora uma crítica da Revolução do ponto de vista do liberalismo da ordem, insistindo principalmente nas catástrofes resultantes do esquecimento, por parte dos revolucionários, da ordem e do poder encarregado de a garantir, o Executivo. Lezay-Marnésia, em contraste, quer conciliar a França com a história turbulenta de sua Revolução, demonstrando que, apesar dessa turbulência, a Revolução pode, considerada em seu legado completo, ser conciliada com o valor da ordem.

Essa tentativa de reconciliar a história da Revolução com o valor da ordem leva Lezay-Marnésia a uma compreensão inédita do Terror no campo do liberalismo da ordem. Essa compreensão é muito distante da de Necker, quem vê no Terror apenas a consequência nefasta do esquecimento da ordem pelos constituintes e das catástrofes disso resultantes, a destruição da monarquia e o regicídio (NECKER, 1797, tomo I, Parte II, Seção VII; NECKER, 1797, tomo II, Parte III, Seção I). Ela é muito distante também da visão do Terror consagrada por Roederer nos discursos lidos por Tallien à Convenção, nos quais o Terror é o arbítrio destruidor de toda ordem e de todo governo. Todavia, o mesmo Roederer que havia formulado esses discursos publica o texto de Lezay-Marnésia e o elogia em seu Journal d'économie publique, indicando que a reabilitação do Terror empreendida por seu colaborador podia servir aos objetivos presentes do liberalismo da ordem em 1797.

A chave dessa reabilitação do Terror é a divisão da Revolução em três etapas. Em De la faiblesse, Lezay-Marnésia já havia estabelecido sua divisão entre as fases da 
liberdade, da igualdade e da ordem. Em Des causes, ele retoma essa divisão, acrescentando que, no início, as revoluções populares progridem pela impetuosidade do povo, triunfando, no fim, pelo sentimento inverso, a necessidade de repouso e a aversão a novas reviravoltas. A época mais crítica é, portanto, o meio, quando não há mais o fervor do povo, mas ainda não despontou sua lassidão: “quando essas revoluções não são mais sustentadas pelo fervor do povo e ainda não o são por sua lassidão, elas fracassariam por falta de força se não lhes sobreviesse, por volta do meio, um reforço; e esse reforço é o terror" (LEZAY, 1797, p. 28).

Lezay-Marnésia considera, assim, o Terror como o expediente necessário para sustentar o governo nesse contexto particular que é o meio das revoluções populares. Nesse contexto particular, tudo é tomado pelo caos, e um povo ainda habituado à desobediência é agitado pelas facções, as quais se engajam seja para destruir a Revolução, seja para se apoderar dela. Se já não bastasse, as potências estrangeiras aproveitam esse momento para invadir o país transtornado pela revolução. $O$ terror aparece, então, como a única maneira de "colocar o governo em repouso do lado do povo, reprimindo subitamente o ardor popular e a inquietação dos descontentes” (LEZAY, 1797, p. 32). O terror tira o governo "de setecentas mãos por onde ele flutuava, para fazê-lo passar todopoderoso para as mãos de alguns chefes" (LEZAY, 1797, p. 32), podendo, em consequência, restabelecer a disciplina e a ordem internas por meio do medo generalizado da morte. O próprio arbítrio é necessário para difundir o terror a todos, não somente aos inimigos declarados da Revolução, fazendo todo o povo se curvar e tornando possível o restabelecimento da ordem e da obediência:

\footnotetext{
Cada um tremeu por si mesmo ao ver que a morte não escolhia. E, quando se viu a prontidão com que ela atingia suas vítimas, o terror redobrou. Se a forma dos procedimentos tivesse sido temperada pela esperança, e se a morte só tivesse ameaçado aqueles que ela deveria atingir, ela teria contido somente estes últimos. Como todos foram ameaçados, todos se dobraram (LEZAY, 1797, p. 33).
}

Assim como a obediência do povo, o terror restabelece a disciplina no exército, tornando possível a vitória contra as potências inimigas: "Foi dessa maneira que o terror passou dos exércitos da república para os exércitos inimigos. Eles não puderam mais resistir a homens que acreditavam fugir da morte ao ir em sua direção" (LEZAY, 1797, p. 34).

A natureza das revoluções populares se une, assim, às circunstâncias específicas da Revolução Francesa, repletas de perigos e obstáculos, para impor a necessidade do 
Terror em 1793: "Um poder sujeito a regras e limitado por uma Constituição teria infalivelmente sucumbido sob essa multidão de obstáculos e de inimigos que, vindos de todas as partes, atacavam a França" (LEZAY, 1797, p. 43). Lezay-Marnésia vai além dessa constatação, chegando a afirmar que "esse despotismo devia preparar a via para uma Constituição livre, e não há dúvida de que, se ele não a houvesse precedido, ela jamais teria podido se estabelecer" (LEZAY, 1797, p. 44). Como Necker, LezayMarnésia é obcecado pelo "mistério da obediência". Para ele, quanto menos um povo sabe obedecer, "menos ele é próprio para a liberdade, pois, quanto menos ele se contém a si próprio, mais ele precisa de força para ser contido" (LEZAY, 1797, p. 44). Depois do momento anárquico inicial da Revolução, era necessário um despotismo arbitrário e violento para ensinar novamente o povo a obedecer, a fim de que ele pudesse posteriormente obedecer às leis de um regime livre. Outro efeito do Terror foi, segundo o autor, a destruição dos antigos hábitos, consolidando novos costumes para cujo estabelecimento, em circunstâncias normais, seriam necessários séculos. O despotismo terrorista teria produzido "um povo novo" (LEZAY, 1797, p. 45).

Como compreender esse elogio do Terror por parte de um autor político cujas bases teóricas estão ligadas mais a Necker do que a Robespierre? Baczko e Ozouf sugerem a existência de um discurso pós-jacobino sobre o Terror no contexto termidoriano. Oposto ao discurso antijacobino e a seu apelo à punição dos terroristas, cuja ilustração principal é fornecida pelos discursos de Tallien escritos por Roederer, esse discurso pós-jacobino explica e justifica o Terror à luz das "circunstâncias fatais" que cercaram a Revolução Francesa, tornando necessário um governo de ferro capaz de superar os obstáculos à Revolução e vencer seus inimigos por meios tirânicos. O discurso pós-jacobino é tão termidoriano quanto o discurso antijacobino, na medida em que ele também celebra o 9 Termidor e abomina igualmente a figura de Robespierre. Apesar disso, ele compreende sua tirania à luz de uma necessidade histórica ligada às circunstâncias específicas da Revolução, opondo-se à linguagem voluntarista do discurso antijacobino e a seus clamores contra os "monstros sanguinários". Baczko associa o discurso pós-jacobino às manobras de convencionais como Bertrand Barère e Robert Lindet para frear o elã punitivo que avançava sobre a Convenção pouco após o 9 Termidor (BACZKO, 1989b). Ozouf inclui Des causes de Lezay-Marnésia na categoria de “discurso pós-jacobino", sublinhando que ele, diferentemente de Lindet, não precisava justificar sua conduta como membro do Comitê de Salvação Pública: "sua preocupação é 
apenas defender a Constituição do Ano III" (OZOUF, 1994, p. 9). Ora, sabe-se que LezayMarnésia era um crítico da Constituição de 1795 - ele chega a retomar essas críticas em Des causes, embora de modo atenuado. Como entender essa retomada do discurso pósjacobino no interior do liberalismo da ordem, em um contexto em que a questão não era mais a punição dos terroristas?

É comum caracterizar o texto de Lezay-Marnésia pelo estilo Realpolitik (GAUCHET, 1989, p. 163; BARBERIS, 1998a, p. 510). Na interpretação aqui desenvolvida, o mais crucial para o autor não era essa ostentação de Realpolitik, mas antes a radicalização da divisão da Revolução Francesa em três etapas, já esboçada em De la faiblesse, e a revelação de todas as consequências dessa divisão. Destaca-se na brochura de Lezay-Marnésia a profunda descontinuidade entre as três fases da Revolução: necessário na segunda etapa, o arbítrio é deslocado e mesmo impossível na terceira e última:

\begin{abstract}
Quando os principais obstáculos enfrentados por uma revolução popular são superados e ela chega a seu fim, ou seja, quando o voto dominante do povo é por repouso e ordem, é chegado o momento de lhe dar uma Constituição. Um governo arbitrário e violento não seria, então, menos deslocado do que um governo limitado no meio da revolução, ou qualquer espécie de governo em seu início (LEZAY, 1797, p. 48).
\end{abstract}

Desse modo, a justificação do arbítrio terrorista vem de par com a consideração da impossibilidade do arbítrio no momento presente da ordem constitucional. O argumento de Lezay-Marnésia não é que os perigos enfrentados pela República exigem sempre medidas arbitrárias, mas antes que as medidas arbitrárias empregadas no passado recente decorriam de um tempo histórico qualitativamente diferente, no qual as paixões dominantes eram completamente distintas. É porque o autor vê o arbítrio como deslocado no momento presente, que ele pode justificá-lo quando as circunstâncias e o momento da Revolução eram outros. Ao abraçar o arbítrio passado que teria preparado a ordem presente, Lezay-Marnésia chega à reconciliação completa entre o liberalismo da ordem e a Revolução Francesa. Mesmo tendo examinado o Terror sob outra perspectiva em 17941795, Roederer não poderia senão se entusiasmar com a empreitada histórica e teórica de seu colaborador, divulgando-a com vigor pelo Journal d'économie publique.

Constant dedica o Prefácio à segunda edição de Des réactions politiques a uma refutação de Des causes de Lezay-Marnésia, publicada em maio-junho de 1797 com o título Des effets de la Terreur. Nesse texto, o jovem autor franco-suíço nega categoricamente que o Terror tenha sido necessário para a salvação da República. Ele 
sustenta, pelo contrário, que a República foi salva apesar do Terror, os obstáculos enfrentados pela Revolução sendo eles próprios produtos do Terror. Mesmo os obstáculos que não haviam sido produzidos diretamente pelo Terror teriam sido superados de modo mais eficaz por um regime justo e legítimo, que não utiliza nunca meios arbitrários. Em resumo, seu objetivo é provar "que o Terror fez somente mal, e que foi ele que legou à República atual todos os perigos que, ainda hoje, ameaçam-na de todas as partes" (CONSTANT, 1998a, p. 519).

A base da argumentação de Constant é a divisão do governo revolucionário em duas partes, "a parte governante e a parte atroz, ou o Terror" (CONSTANT, 1998a, p. 520). A primeira parte consiste em todo um aparato legal, repressivo e coercitivo que o governo revolucionário tinha em comum com todos os governos, inclusive os mais equitativos, pela simples razão de que "essa parte é a base da existência de todo governo" (CONSTANT, 1998a, p. 520). O Terror consistia nos meios arbitrários que inspiravam o medo da morte a todos os franceses, independentemente de suas ações. Ora, segundo o autor, foi a parte governante e legítima do governo revolucionário, que restabeleceu a obediência no interior e repeliu os exércitos inimigos no exterior, os meios legais disponíveis a essa parte governante sendo suficientes para superar os obstáculos enfrentados pela Revolução. O Terror, por sua vez, não teria produzido outro efeito além da sublevação dos espíritos, suscitando a revolta de Lyon, a insurreição departamental e a Guerra da Vendeia. Longe de produzir um povo novo com costumes próprios à liberdade, como havia escrito Lezay-Marnésia, os efeitos do Terror foram, segundo Constant, o atrofiamento do espírito público, a profanação do nome "República", a suscitação do espírito de reação e a disposição dos espíritos ao arbítrio.

Como compreender esse esforço de Constant - um defensor ardente da Revolução Francesa, que havia chegado, durante o Terror, a defender o governo revolucionário apesar de seus excessos, ${ }^{46}$ e que, no Diretório, havia sido acusado por Roederer de querer restabelecer o arbítrio por meio do apelo aos terroristas como "artilharia de reserva" do governo - para refutar a justificação do Terror empreendida por Lezay-Marnésia (e publicada e elogiada pelo mesmo Roederer que havia acusado Constant de cumplicidade

46 Ver as cartas de Constant a Isabelle de Charrière durante as primeiras fases da Revolução Francesa, e particularmente na época do Terror, em CONSTANT, 1993; CONSTANT, 1998c. Ver também o comentário dessas cartas em VINCENT, 2000, p. 610-613. 
com os terroristas)? Barberis sugere a oportunidade de uma "ultrapassagem pela direita" (BARBERIS, 1998a, p. 510) em relação ao discurso de Realpolitik de Lezay-Marnésia. Tratava-se, segundo o comentador, de "mostrar à opinião pública moderada que um republicano podia criticar o Terror com bem mais rigor do que um monarquista" (BARBERIS, 1998a, p. 510). Esta tese propõe outra interpretação. Em primeiro lugar, Lezay-Marnésia não era monarquista (como sugere Barberis), logo o que o opunha a Constant não era, de modo algum, a disputa entre Monarquia e República. O que os opunha verdadeiramente era, como vimos, duas interpretações diferentes da Revolução Francesa e do momento termidoriano no qual eles escreviam. Para Lezay-Marnésia, a Revolução havia percorrido três etapas que constituíam, cada uma, tempos históricos qualitativamente diferentes: após o 9 Termidor, a Revolução já estava concluída, seus resultados sendo garantidos pela lassidão do povo e por seu desejo geral de ordem; ${ }^{47} \mathrm{o}$ arbítrio necessário no meio da Revolução era, portanto, deslocado e mesmo impossível após sua conclusão. Para Constant, ao contrário, a Revolução ainda não havia terminado, nem seus resultados estavam ainda garantidos. Sua teoria das reações políticas negava a ideia de tempos qualitativamente diferentes em uma revolução. O que há sempre é a dificuldade de estabelecer um acordo entre as instituições e as ideias de uma época. A necessidade de combater o espírito de reação impedia a simples acomodação do governo à sociedade, que Lezay-Marnésia e Roederer viam como garantida pelo desejo geral de ordem. Essa dificuldade havia feito o problema do arbítrio emergir de modo agudo no pensamento de Constant, o que não era o caso para Roederer e Lezay-Marnésia, para quem o arbítrio era um traço ultrapassado de um passado recente, mas profundamente distinto do presente.

Assim, para Constant, 1793 não é qualitativamente diferente de 1797. Nos dois momentos, tratava-se de instituir e de consolidar os princípios e as instituições da República, contra os partidários da ordem antiga. Em 1797, os partidários do Antigo Regime estão ainda mais ameaçadores, pois eles se fortaleceram com o espírito de reação

${ }^{47}$ Constant interpela diretamente Lezay-Marnésia a esse respeito: "Seria-me permitido perguntar como uma revolução pode ser sustentada pela lassidão do povo? Que um governo seja sustentado por essa lassidão, é possível conceber. Mas uma revolução, eu não consigo entender” (CONSTANT, 1998a, p. 520, nota a; ênfase do autor). Essa passagem esclarece o fato de que, em 1797, Constant pensava ainda em termos de apoio à Revolução (contra o espírito de reação), ao passo que Lezay-Marnésia pensava antes em termos de apoio ao governo saído da Revolução, pois, a seus olhos, esta já havia acabado. 
produzido pelo Terror. Nos dois contextos, coloca-se, portanto, o problema de como proteger a República dos ataques da contrarrevolução sem recorrer aos meios arbitrários. Para Lezay-Marnésia, a justificação do Terror em 1793 não trazia consequências para 1797, pois ele supunha dois tempos históricos qualitativamente diferentes. Para Constant, como não há esse contraste de tempos históricos diferentes, justificar o arbítrio em 1793 implica justificá-lo em 1797, quando a República ainda enfrenta os obstáculos da reação e poderia utilizar esses obstáculos como justificativa para o arbítrio. Daí Constant acusar Lezay-Marnésia de extrair dos erros e dos crimes do passado axiomas que "existem no presente; eles ameaçam no futuro" (CONSTANT, 1998a, p. 518).

Em resumo, a dificuldade de conciliação entre o princípio da soberania do povo e a independência do governo republicano em relação à maioria nacional faz o problema do arbítrio emergir no pensamento do jovem Constant. Esse problema se apresenta, notadamente, na forma da possibilidade do arbítrio mobilizado pela República, a fim de se proteger dos votos públicos da maioria nacional contrários ao próprio regime republicano. Ao assumir o problema do arbítrio, Constant se afasta do liberalismo da ordem, extremamente influente no contexto diretorial, e reata com uma linha de reflexão que remonta a Locke e Rousseau - autores que perceberam a impossibilidade de suprimir completamente a questão do arbítrio, mesmo em uma organização política legítima, buscando antes formas de incorporar o arbítrio ao sistema político de modo controlado. No entanto, Constant não inclui em seu corpo teórico, nem a prerrogativa lockeana, nem a ditadura romana retomada por Maquiavel e Rousseau. O conceito de estado de exceção, influente da Constituinte até o Terror, é igualmente rechaçado, como uma forma de justificar o injustificável arbítrio pelas circunstâncias. A primeira reação de Constant ao problema do arbítrio foi sua rejeição completa erigida em princípio, de modo a eclipsar os casos práticos de aplicação dos meios arbitrários sob a justificativa da salvação da República já considerados por ele, como os decretos dos dois terços e a hipótese do "apelo aos terroristas". O autor procura completar a coerência de sua rejeição radical do arbítrio aplicando-a ao Terror de 1793-1794, guiado pelo raciocínio segundo o qual a justificação do arbítrio em 1793 abriria portas para a justificação do arbítrio em 1797, quando a França ainda enfrentava o espírito de reação e precisava de "grandes precauções e um cuidado extremo, para se opor ao renascimento dos privilégios" (CONSTANT, 1998a, p. 457458). Dito isto, longe de assegurar uma coerência de sistema, essa operação teórica resultava em um equilíbrio tenso e precário entre a independência do governo 
republicano, a soberania do povo e a rejeição radical do arbítrio. Alguns meses mais tarde, o golpe de Estado do 18 Frutidor coloca esse equilíbrio à prova, obrigando-o a mudar de configuração. 


\section{Capítulo 2: Reavaliando o arbítrio após o golpe do 18 Frutidor}

É um consenso historiográfico que o golpe do 18 Frutidor do Ano V (4 de setembro de 1797) representou um divisor de águas na história do Diretório. Em seus quase dois anos anteriores, ${ }^{48}$ o governo diretorial parecia seguir a recomendação de Constant de evitar o emprego do arbítrio no enfrentamento dos obstáculos, e a República parecia entrar pouco a pouco em uma normalidade institucional caracterizada pelo império da lei, pela competitividade eleitoral e pela liberdade de imprensa. Porém, essa perspectiva é abalada pela vitória da direita na eleição de abril de 1797, quando a renovação de um terço dos Conselhos resulta em um crescimento expressivo da direita de tendência monarquista, a qual alcança cerca de $45 \%$ dos assentos e passa a pressionar ativamente o Diretório. Torna-se então evidente o que alguns já intuíam: a legitimidade republicana continuava longe de ser consolidada em uma França organizada socialmente em comunidades locais centradas na Igreja e ainda não integradas a uma República vista por muitos como imposta pela força (BROWN, 2006, p. 29-30). A expressão oficial da opinião pública dava, assim, força ao diagnóstico de Constant sobre a reação política em curso, tornando candente para toda a República o problema do arbítrio eventualmente necessário para salvá-la. ${ }^{49}$

Como é sabido, o arbítrio não tardou em se escancarar, na forma do golpe militar. Os três diretores republicanos que ainda formavam maioria no governo (Reubell, La Révellière-Lépaux e Barras) organizam, com o exército, o golpe do 18 Frutidor, resultando na prisão de um grande número de deputados acusados de participar de uma conspiração monarquista. No dia seguinte, os dois Conselhos votam, sob pressão, a

${ }^{48}$ Os "vinte meses" de existência republicana cuja supressão é lamentada por Madame de Staël nas Considérations sur les principaux événements de la Révolution française, publicadas postumamente em 1818 (STAËL apud GUENIFFEY, 2011, p. 372, nota 40).

${ }^{49}$ É verdade que, segundo Gueniffey (2008, p. 63-72; 2011, p. 361-371), a vitória eleitoral de uma direita com simpatias monarquistas não representava por si só uma ameaça inexorável à República, pois, salvo uma minoria radical e barulhenta, a maioria dos membros dessa direita ascendente em 1797 parecia disposta a respeitar a Constituição de 1795 enquanto não estivessem postas as condições para uma restauração da monarquia em um espírito próximo ao de 1789. Contudo, importa, para esta tese, menos a ameaça efetiva à República, do ponto de vista dos historiadores contemporâneos, do que a percepção e a dramatização dessa ameaça no círculo político republicano ao qual Constant pertencia. 
invalidação da eleição de 154 deputados e a deportação para a Guiana, sem julgamento, dos dois diretores realistas (Carnot e Barthélemy), de 53 deputados, vários ministros e dezenas de jornalistas (GUENIFFEY, 2008, p. 73; GUENIFFEY, 2011, p. 372). Para alguns historiadores, tratava-se de uma guinada autoritária da República termidoriana mais decisiva do que a proporcionada pelo golpe do 18 Brumário, dois anos depois (BROWN, 2006, p. 120). O exército é mobilizado em escala nacional, comissões militares são formadas após o golpe para reprimir os inimigos do regime, naquilo que ficou conhecido como "Terror frutidoriano" (BROWN, 2006, pp. 152-153), e a imprensa é colocada sob a vigilância da polícia, com diversos jornais de oposição fechados. Novas leis repressivas são instituídas contra os emigrados que haviam retornado à França e os clérigos refratários. As candidaturas públicas são novamente proibidas, e é restabelecido o sermão obrigatório de “ódio à realeza e à anarquia”. Enfim, era um Segundo Diretório que começava, com os traços de uma nova ditadura republicana mal disfarçada.

Neste capítulo, propomos compreender o golpe do 18 Frutidor como um divisor de águas não apenas na história do Diretório, mas também no pensamento político de Constant. No final do capítulo anterior, foi sugerido que o 18 Frutidor colocou à prova 0 equilíbrio tenso por meio do qual caracterizamos os escritos de Constant sob o Primeiro Diretório: o equilíbrio entre a independência do governo republicano em relação à maioria nacional, o princípio da soberania do povo e a rejeição categórica do arbítrio. A noção de "prova" está sendo utilizada aqui como um modo de estudar a interação entre a teoria política e a realidade política a partir da qual aquela é formulada e sobre a qual ela procura intervir. A referência são as duas obras mencionadas na Introdução como inspirações metodológicas para esta tese: os livros Le moment Guizot, de Rosanvallon (1985), e Robespierre: L'homme qui nous divise le plus, de Gauchet (2018). Como vimos na Introdução, ambos os pesquisadores insistem, no estudo de seus respectivos personagens históricos, em não separar suas ideias de sua prática política, analisando os percalços da experiência prática como provas que obrigam o pensamento a se reformular (cf. p. 18 supra).

Ao propor entender o golpe do 18 Frutidor como uma prova ou teste do pensamento do jovem Constant, analogamente ao modo como Rosanvallon entende a Monarquia de Julho como um teste do sistema conceitual formulado por Guizot durante a Restauração, ou ao modo como Gauchet trata a entrada de Robespierre no governo como um evento que o levou a reavaliar sua recusa do Poder Executivo, nosso objetivo é 
reinterpretar o pensamento de Constant em sua interação dinâmica com a prática política, algo que as interpretações correntes do autor têm muita dificuldade de realizar. No que se refere à atitude de Constant perante o golpe do 18 Frutidor - mais especificamente, sua defesa do golpe no Discours prononcé au Cercle constitutionnel pour la plantation de l'Arbre de la Liberté, le 30 fructidor an $V$-, as atitudes predominantes dos intérpretes podem ser classificadas em três grupos: 1) intérpretes que denunciam no apoio ao golpe uma hipocrisia de Constant, cujos princípios liberais seriam apenas um disfarce oportunista para seu verdadeiro engajamento a favor da burguesia; 2) intérpretes que veem no apoio ao golpe um desvio de Constant em relação a seus princípios, o qual é explicado por circunstâncias históricas e biográficas, mas sem impactar ou comprometer sua teoria política; 3 ) intérpretes que buscam estabelecer uma coerência entre a teoria política de Constant e seu apoio ao golpe.

Talvez o maior exemplo da primeira atitude seja fornecido por Albert Mathiez em seu artigo "Saint-Simon, Lauraguais, Barras, Benjamin Constant, etc. et la Réforme de la Constitution de l'an III après le Coup d'Etat du 18 fructidor an V', publicado em 1929. Segundo Mathiez,

o liberalismo de Benjamin Constant era um liberalismo intermitente. Ele
acabava de aplaudir ao 18 Frutidor e compreendia o liberalismo somente como
subordinado à defesa da propriedade. Ele teria se acomodado muito bem a um
governo forte que, a exemplo do de Cromwell, garantisse os aproveitadores do
regime contra o retorno dos banidos pela Revolução Francesa e contra os
projetos dos partidários da igualdade real (MATHIEZ, 1929, p. 11).

Nessa visão, não há propriamente uma interação dinâmica entre as ideias e a práxis política. Os princípios são apenas um acessório subordinado à práxis - ela própria reduzida neste caso à defesa da propriedade. Esse acessório seria tão secundário que nem mesmo um mínimo de coerência intelectual seria exigido: diante da primeira necessidade, a máscara das ideias seria abandonada, e o liberalismo cederia a sua verdade última, segundo a qual qualquer meio é válido para garantir a propriedade burguesa.

A segunda atitude pode ser encontrada no artigo de Alain Laquièze intitulado “Etat d'exception et coup d'Etat dans la pensée du Groupe de Coppet". Segundo Laquièze, o golpe do 18 Frutidor provoca em Constant e Madame de Staël o embaraço de uma "tensão entre, por um lado, a aceitação do golpe de força necessário para salvar a liberdade e, por outro lado, a reprovação de uma jornada que só foi possível porque a Constituição do Ano III era ruim" (LAQUIÈZE, 2003, p. 47). Entretanto, a ênfase do intérprete reside no fato de que os autores reveem sua posição e lamentam seu apoio ao 
golpe na fase madura de seu pensamento. Tratar-se-ia, então, de um desvio de juventude que não comprometeria a coerência de um liberalismo moral que, mais do que qualquer teoria política anterior, rejeitaria a legitimidade do golpe de Estado e da violação constitucional em qualquer circunstância, mesmo diante do apelo clássico ao salut public. O golpe do 18 Frutidor pertenceria ao "mundo das circunstâncias e da subjetividade" (LAQUIÈZE, 2003, p. 60), não ao universo das escolhas racionais e justificáveis. Embora essa perspectiva leve o pensamento político de Constant muito mais a sério do que a de Mathiez, ela tampouco abre espaço para uma investigação profunda da interação dinâmica entre sua teoria e sua prática política, pois o que se sugere é uma relação de exterioridade entre as duas dimensões. No máximo, há a sugestão de que o arrependimento posterior de Constant e Staël sobre seu apoio ao golpe influencia sua rejeição categórica do arbítrio. Contudo, não parece haver o entendimento de que a tensão e o embaraço vividos por ambos no "mundo das circunstâncias e da subjetividade" tenham se refletido de algum modo como tensão em suas próprias teorias. Inversamente a Mathiez, há uma independência e uma superioridade da teoria política de Constant em relação aos percalços de sua práxis. Os reflexos teóricos desses percalços aparecem no máximo como arrependimentos. ${ }^{50}$

Por fim, a terceira atitude, aquela que postula a coerência entre a teoria política de Constant e seu apoio ao golpe do 18 Frutidor, pode ser encontrada de modo cristalino no livro de Stephen Holmes, Benjamin Constant and the Making of Modern Liberalism, de 1984. Segundo Holmes, foi o caos de uma nação sem soberania, não meramente um lapso de princípio
pessoal, que levou Constant a apoiar o golpe de Estado do Diretório em
Frutidor de 1797 , e eventualmente (embora não inicialmente) o golpe de
Estado de Bonaparte em Brumário de 1799. Embora possa ter havido alguma
medida de oportunismo envolvida aqui, não havia inconsistência filosófica.
Antes que o poder de um governo possa ser limitado, esse poder precisa existir,
e, onde ele não existe, ele precisa ser construído ou reconstruído. O
reconhecimento desse fato subjaz à aquiescência relutante de Constant às
medidas extraconstitucionais do Diretório e eventualmente à tomada do poder
por Bonaparte (HOLMES, 1984, p. 11-12).

${ }^{50}$ Uma atitude similar pode ser encontrada em Biancamaria Fontana, quem explica o apoio de Constant ao golpe de Estado (ela pensa sobretudo no de 18 Brumário, não no de 18 Frutidor) pela influência do meio político-intelectual em que ele estava inserido e pelo medo das ameaças neojacobina e contrarrevolucionária, mas a ênfase recai igualmente no arrependimento posterior e na formulação de uma teoria política que rejeita os golpes de Estado em quaisquer circunstâncias (FONTANA, 1991, p. 27-28). 
Uma visão mais nuançada sobre a coerência entre a teoria e a prática políticas de Constant durante o Diretório é fornecida por Aurelian Craiutu, no Capítulo 6 de A Virtue for Corageous Minds: Moderation in French Political Thought, 1748-1830, de 2012. Segundo Craiutu (2012, p. 212-213), Constant estava inserido, ao lado de autores como Jean-Baptiste Say, na busca por um partido de "extremo centro", o qual pudesse conduzir a República para a adoção de princípios de moderação e para o banimento do arbítrio, mas que estivesse igualmente em condições de usar a força para repelir qualquer tentativa de sabotar a República moderada, por parte dos monarquistas ou dos neojacobinos. O intérprete considera a prática política de Constant durante o Diretório como um caso privilegiado para o estudo dos paradoxos e das dificuldades da moderação política (uma tradição política consistente que, na França, remete a Montesquieu), porém não deixa de ressaltar a coerência, a plausibilidade e mesmo a positividade de uma "moderação animada" como a do autor franco-suíço, uma prova da possibilidade de conjugar a busca de fins moderados com um engajamento político-partidário determinado, enérgico e entusiástico (CRAIUTU, 2012, p. 239).

Nessa linha de interpretação representada por Holmes e Craiutu, não há tampouco uma interação dinâmica entre a teoria e a prática políticas que produz tensões na elaboração teórica, mas uma coerência filosófica que se estende mesmo às ações políticas aparentemente mais cínicas. Como vimos na Introdução, o próprio Constant se esforçou ao longo de sua vida para ressaltar a coerência de sua trajetória política, a fim de justificar os vaivéns que muitas vezes chocaram seus contemporâneos e lhe renderam a alcunha de “l'inconstant Benjamin". Nos vários momentos em que o autor se viu obrigado a fornecer tais justificativas, foi ressaltada a constância dos princípios políticos defendidos. Se a prática política decorrente desses princípios pareceu por vezes incoerente, isso se deveria ao caráter confuso e instável do ambiente político sobre o qual Constant procurou intervir, não a um cinismo ou a uma incoerência dos princípios. Embora a maioria dos contemporâneos de Constant não pareça ter sido convencida a respeito de sua coerência, esse atributo é a característica central ressaltada por algumas de suas biografias recentes - por exemplo a de Kurt Kloocke (KLOOCKE, 1984).

O risco de procurar entender o apoio de Constant ao 18 Frutidor como compatível com uma coerência filosófica que englobaria o evento é incorrer naquilo que Quentin Skinner chamou de "mitologia da coerência". Essa mitologia consiste na crença de que a tarefa do estudioso de teoria política, perante uma aparente contradição encontrada no 
"sistema filosófico" de um autor clássico, é a de "fornecer a esses textos a coerência que parece estar faltando" (SKINNER, 2002a, p. 67). Rosanvallon critica igualmente essa compreensão da tarefa do estudioso de teoria política, a qual é chamada por ele de reconstrutivismo: “A análise e o comentário têm por objeto prático, nesse caso, reescrever uma obra para estabelecê-la em uma coerência e uma clareza supostamente ausentes no autor" (ROSANVALLON, 1986, p. 99). Como na segunda atitude, a linha de interpretação movida pela mitologia da coerência faz da teoria política um sistema fechado que paira acima das dificuldades da prática política, sem se perguntar sobre os intercâmbios entre as duas dimensões. A única diferença é que o que a segunda atitude considera como um desvio é visto pela terceira atitude como uma aplicação da teoria ao caso concreto.

Assim, as três linhas de interpretação predominantes sobre o apoio de Constant ao golpe do 18 Frutidor têm o defeito de obscurecer a interação dinâmica entre a teoria e a prática políticas como produtora de tensões e complexidades na própria teoria. No primeiro caso, o apoio ao golpe do 18 Frutidor revelaria "o verdadeiro Constant", mas com o preço de menosprezar sua teoria como mero disfarce inconsistente. No segundo e terceiro casos, o apoio inicial ao golpe é secundário para a compreensão da suposta teoria política coerente constantiana, seja por esse apoio ser um desvio de juventude ou uma aplicação da teoria que não a tensiona.

A compreensão do golpe do 18 Frutidor como um teste do pensamento do jovem Constant tem por objetivo levar a sério a prática política como uma dimensão que coloca desafios à teoria e a obriga a se reformular para dar conta desses desafios. Desse modo, a reação do autor ao golpe, primeiramente no Discours prononcé au Cercle constitutionnel pour la plantation de l'Arbre de la Liberté, receberá nesta tese um peso interpretativo muito maior do que o usual nas interpretações de Constant. Ao contrário de Mathiez, nós não interpretaremos esse apoio inicial ao golpe como uma simples manifestação de hipocrisia, mas antes como uma tentativa de mobilizar e proteger o equilíbrio tenso dos escritos do primeiro Diretório entre a independência do governo republicano em relação à maioria nacional, o princípio da soberania do povo e a rejeição categórica do arbítrio. Ao contrário de Holmes, porém, nós não interpretaremos essa ação política como uma simples aplicação coerente da teoria, mas antes como um momento no qual o equilíbrio teórico se rompe perante a prova da experiência, tendo por resultado uma visível e incômoda contradição. E, diferentemente de Laquièze e Fontana, nós não interpretaremos 
essa contradição como um desvio de juventude que não deixou marcas profundas em uma teoria marcada pela rejeição categórica do arbítrio. Pelo contrário, argumentaremos que a percepção dessa visível e incômoda contradição levou Constant a uma reformulação capital em sua teoria política, a qual buscou incorporar o arbítrio em uma forma controlada.

Sendo esta tese guiada por uma abordagem contextualista, não basta remeter as reformulações teóricas de Constant aos eventos políticos de sua época - neste caso, com especial ênfase no golpe do 18 Frutidor. É preciso considerar também as respostas de outros integrantes de seu entourage político e intelectual ao mesmo evento. Afinal, não foi apenas Constant, mas todo o seu meio político e intelectual que reorientou seu pensamento para responder a um evento tão crucial como o 18 Frutidor. Em sua reformulação teórica, empreendida fundamentalmente nos Fragments d'un ouvrage abandonné sur la possibilité d'une constitution républicaine dans un grand pays, Constant considera e responde às respostas de autores próximos ao 18 Frutidor, incorporando alguns elementos dessas respostas, mas também as criticando. Procuraremos mostrar que, em todas essas respostas, o arbítrio aparece como um problema implícito ou explícito, mas que Constant se mostra insatisfeito com o modo como os autores de seu entorno respondem a esse problema.

Assim, o desenvolvimento deste capítulo fará o seguinte percurso: Na Seção 2.1, analisamos a reação imediata de Constant ao golpe do 18 Frutidor, no Discours prononcé au Cercle constitutionnel pour la plantation de l'Arbre de la Liberté. Na Seção 2.2, examinamos as respostas fornecidas por outros autores próximos a Constant ao mesmo evento: em primeiro lugar, a da corrente que chamamos de "liberalismo da ordem", por meio de Roederer; depois, a de Napoleão Bonaparte, em carta secreta enviada a Talleyrand em 21 de setembro de 1797; em seguida, a de Madame de Staël, em Des circonstances actuelles qui peuvent terminer la Révolution et des principes qui doivent fonder la République en France; logo após, consideramos o golpe do 18 Brumário como uma resposta à crise aberta pelo 18 Frutidor e uma tentativa de resolvê-la; portanto, o projeto constitucional de Sieyès que resulta na Constituição do Ano VIII (1799) e as justificativas para essa Constituição, nas penas de autores como Roederer e Cabanis, são também analisados como respostas ao 18 Frutidor; por fim, a crítica de Necker à Constituição de 1799 e seu desenho constitucional alternativo são considerados como uma última resposta à problemática aberta pelo 18 Frutidor a influenciar diretamente 
Constant. O capítulo termina, na Seção 2.3, com uma análise dos Fragments de Constant, entendidos como uma primeira reformulação teórica decorrente do golpe do 18 Frutidor, a qual consiste fundamentalmente em uma incorporação controlada do arbítrio ao sistema institucional.

\subsection{Uma defesa contraditória do golpe}

Não se sabe ao certo o grau de envolvimento que Constant teve no planejamento do golpe do 18 Frutidor. Não restam dúvidas, porém, sobre o lado em que o autor se encontrava. Ele havia sido um dos fundadores do Cercle constitutionnel, organização estabelecida em junho de 1797, com o objetivo de agrupar os parlamentares fiéis ao Diretório republicano e se opor ao clube monarquista de Clichy. Doze dias após o 18 Frutidor, o já conhecido autor de De la force du gouvernement defende o golpe em um eloquente discurso pronunciado no Cercle constitutionnel (Discours prononcé au Cercle constitutionnel pour la plantation de l'Arbre de la Liberté, le 30 fructidor an V), o qual o Diretório se apressa em imprimir e fazer circular.

É interessante notar a continuidade desse discurso de Constant em relação a seus escritos anteriores. Tendo já teorizado a reação política em curso antes de ela se escancarar com a eleição de abril de 1797, o autor já havia contrabalançado o princípio da soberania do povo com o da independência do governo republicano em relação à maioria nacional desde pelo menos 1796, com De la force du gouvernement. Na realidade, essa problemática havia emergido em seu pensamento já em 1795, com sua mudança de posição a respeito dos decretos dos dois terços, como vimos no Capítulo 1. Como vimos também no primeiro capítulo, a independência do governo republicano em relação à maioria nacional se fundava, em 1796, em uma distinção entre justiça e imparcialidade e em uma defesa da parcialidade republicana dos dirigentes da República. Ora, esse argumento, já formulado em 1796, constitui a base principal da defesa do golpe do 18 Frutidor em 1797. O argumento é apenas levado mais longe, a ponto de Constant pregar uma centralização do poder nas mãos dos republicanos e uma exclusão total dos monarquistas, e mesmo dos republicanos que não parecessem convictos, das funções públicas: 
(...) como está bem demonstrado que somente os republicanos podem fazer avançar a República, que, a partir do 18 Frutidor, eles marchem, não mais com o recurso de vitórias periódicas, mas com a segurança calma e constante do poder, centralizado em suas mãos. Apenas essa centralização assegurará a liberdade (CONSTANT, 1964, p. 118-119).

No Capítulo 1, argumentamos que o imperativo da independência do governo republicano em relação à maioria nacional, em um quadro político no qual se admite a soberania do povo, fazia o problema do arbítrio emergir de modo agudo, e que Constant respondia a isso com uma rejeição categórica do arbítrio. A mesma rejeição do arbítrio é repetida no discurso do 30 Frutidor, logo no início do pronunciamento, após o autor fazer um aceno à moderação e celebrar que, dessa vez, os republicanos não precisaram recorrer à pena de morte para derrotar seus inimigos:

Mas não é suficiente haver excluído a morte dos meios da República. É preciso ainda excluir o arbítrio: o arbítrio, incompatível com a existência de todo governo, destruidor de tudo o que ele atinge, vício corruptor de toda instituição, eterno inimigo, por sua essência, de toda dignidade, de toda duração, de toda força real (CONSTANT, 1964, p. 116).

Como exposto no final do Capítulo 1, Constant não havia integrado a independência do governo republicano em relação à maioria nacional, o princípio da soberania do povo e a rejeição categórica do arbítrio em um sistema filosófico coerente. Tratava-se antes de um equilíbrio tenso e precário. No entanto, é sob a prova da experiência que a contradição se torna evidente, pois o autor se vê rejeitando categoricamente o arbítrio em um discurso destinado a fazer a defesa de um golpe de Estado. Nesse discurso, a contradição só pode ser contornada por meio de um expediente inspirado nos jacobinos: embora a erradicação do arbítrio seja a meta, ela ainda não pode ser alcançada porque a França ainda não se libertou totalmente de seu passado monárquico.

\footnotetext{
Ora, nada pode substituir o arbítrio, a não ser a força moral das instituições. O poder da convicção é indispensável para quem quer renunciar à violência, e, para nos proibir para sempre o recurso perigoso aos abalos ilegais, é preciso nos assegurar uma marcha progressiva e regular. Mas quantos obstáculos se apresentam, quantas dificuldades nos cercam! Uma educação monárquica, usos monárquicos, lembranças monárquicas, castas monárquicas nos assediam de todas as partes. Quatorze séculos de realeza comprimiram a maioria das almas (CONSTANT, 1964, p. 116-117).
}

Como os jacobinos haviam feito quatro anos antes, Constant utiliza a batalha ainda travada contra os inimigos da República para justificar uma flexibilização de seus princípios em um quadro excepcional. Aplica-se aqui quase literalmente o que Gauchet escreve sobre Robespierre: 
O fato é que ele descobre, sob a prova de circunstâncias extraordinárias, a necessidade daquilo que ele recusa ou reprova em princípio - e, como as circunstâncias são extraordinárias, a descoberta não recoloca em questão os princípios. (...) A prática funciona, em poucas palavras, como o recalcado da teoria (GAUCHET, 2018, p. 135-136).

Constant não prega o governo revolucionário posto em prática pelos jacobinos e cujos meios ele criticara tão vigorosamente poucos meses antes, em Des effets de la Terreur, mas o governo que ele reivindica, centralizado de modo absoluto nas mãos dos republicanos convictos, não deixa de trazer algumas marcas do estado de exceção. Tratase de um governo que deve utilizar todos os meios à sua disposição para manter o poder nas mãos dos republicanos convictos, de modo a impedir que a livre competição eleitoral coloque os direitos do povo nas mãos de pessoas que não acreditam nesses direitos:

Vocês que quiseram a República, que a conquistaram, que a fundaram, cabe a vocês conservá-la. Só têm direito à liberdade os que a creem possível. Ela pertence a quem a quer. Aqueles que a colocam constantemente em dúvida devem gozar de sua proteção, mas não de seus favores. Aqueles que não creem nos direitos do povo devem ser deserdados desses direitos. Que eles vivam pacificamente, mas sem poder; assegurados em relação a seus bens, mas sem destaque; garantidos em sua insignificância, mas sem condições de sair dela... (CONSTANT, 1964, p. 120).

Assim, Constant afasta o imaginário violento do governo revolucionário de 1793, mas sugere uma ditadura republicana que monopoliza o poder e impede que haja em qualquer função da República, "desde o administrador municipal da menor comuna até os depositários supremos da autoridade executiva", "um único homem que não seja solidário da liberdade republicana, que não tenha assumido com ela engajamentos indissolúveis, que não carregue em sua alma a confiança em sua força, a certeza de sua duração e a entrega da mais completa devoção a ela" (CONSTANT, 1964, p. 120). Essa ditadura republicana, não totalmente assumida, mas insinuada, deve se empenhar em expropriar a aristocracia não apenas dos meios diretos de poder, mas também dos meios de influência indireta. Nesse terreno dos meios de influência indireta, o governo deve prestar atenção especial na batalha necessária contra a moda:

A moda, esse poder artificial, mas multiforme, empresta seu apoio ao monarquismo. (...). Ela se encontra, por natureza, em luta contra tudo o que é instituído. Ela atrai para si tudo o que deseja fazer efeito, e quem não deseja fazer efeito na França? (...). Ela se compõe, hoje, das lembranças do antigo regime e da depravação do novo. Ela tem, desse modo, pontos de contato com todos os estados e todas as idades. (...) a moda reúne, contra as instituições republicanas, um exército que não é temível, mas numeroso (CONSTANT, 1964, p. 121-122). 
Como Robespierre alguns anos antes, ${ }^{51}$ Constant considera como a pedra angular da consolidação da República uma guerra cultural destinada a apagar a herança de séculos de monarquia e enraizar os novos costumes republicanos, sem os quais a aristocracia continuará gozando de prestígio social e minando a nova ordem política por dentro: “É preciso sufocar a moda, aviltar a aristocracia, fechar todos os lugares públicos onde ela faria novas conquistas, exibindo um luxo insultante e se atribuindo um direito de exclusão" (CONSTANT, 1964, p. 122). Como programa positivo, é necessário, "pelo contrário, popularizar o prazer, revestir a liberdade de esplendor e de pompa, conferir a todas as festas a marca republicana, fazer com que o orgulho nobiliárquico se encontre sem cessar ofendido" (CONSTANT, 1964, p. 122). O orador enfatiza que essa "guerra cultural" não envolve perseguições, mas apenas uma parcialidade dos dirigentes da República na direção das festas e das diversões, as quais devem consolidar os sentimentos e costumes republicanos e extinguir os de origem monárquica ou nobiliárquica: "Todas essas medidas podem ser tomadas sem perseguição. Um governo não garante aos homens suas diversões, mas sua segurança. $\mathrm{O}$ repouso deve ser compartilhado por todos, mas o poder e o prazer devem pertencer exclusivamente à República" (CONSTANT, 1964, p. 122).

Em suma, Constant reitera e radicaliza a necessidade da parcialidade republicana do governo, a qual deve se traduzir em um monopólio do poder e em um amplo programa de guerra cultural. A flexibilização momentânea das barreiras constitucionais é admitida como indispensável em um momento-chave da guerra contra a contrarrevolução, mas essa admissão vem acompanhada da condenação do arbítrio e da sugestão de que a Constituição voltou a vigorar de modo absoluto logo após o golpe:

Assim, vemos as barreiras da Constituição, por um instante abaixadas com
vistas ao interesse geral, se reerguerem em seguida, consagradas ao mesmo
tempo pelo respeito unânime e pela implícita resignação de todas as ambições
particulares. Esses três diretores, que haviam salvado a Pátria, convocaram
dois novos colegas para a partilha de seu poder. Eles fizeram toda consideração
pessoal se curvar perante a Constituição, eles que haviam feito a Constituição
se curvar perante a salvação da República (CONSTANT, 1964, p. 127).

Na prática, não era um emprego pontual do arbítrio, mas uma verdadeira guinada autoritária do regime diretorial que estava sendo legitimada por Constant. Em certo

51 Ver especialmente seu "Rapport sur les rapports des idées religieuses et morales avec les principes républicains et sur les fêtes nationales", lido na Convenção Nacional em 7 de maio de 1794 (ROBESPIERRE, 1840, p. 607-642). 
sentido, era sua própria asserção de que o arbítrio nunca pode ser pontual, na medida em que atos arbitrários preparam sempre novos atos arbitrários e culminam no Terror, que estava sendo confirmada. O fato de Constant, nessa ocasião, não ter tirado todas as consequências de sua condenação categórica do arbítrio, já formulada, contribuiu para manchar sua biografia, para lamento de autores posteriores que admiravam suas ideias. É o caso de Alexis de Tocqueville, quem comenta a crítica ao arbítrio e à violação das formas legais pelos homens de bem, enunciada em De la force du gouvernement, nas notas do segundo volume de $O$ Antigo Regime e a Revolução:

Que isso é verdadeiro e mesmo profundo e, além do mais, bem dito! (...) O que é digno de observação é que B. Constant, que escrevia essas linhas em 1796, aplaudia em 1797 ao 18 Frutidor, alinhando-se assim, de maneira prática, ao lado daqueles canalhas menos perigosos que, ao violar as leis, tiveram ao menos o cuidado de não as violar a não ser contra as pessoas honestas! (TOCQUEVILLE, 2004, p. 676).

Esta tese evita condenar ou absolver Constant por seu apoio ao golpe do 18 Frutidor. Interessa-nos aqui, como já sugerido, apreender esse golpe como uma prova ao equilíbrio que Constant procurava estabelecer entre a independência do governo republicano em relação à maioria nacional, o princípio da soberania do povo e a rejeição categórica do arbítrio. Diante dessa prova posta pela experiência, o autor julgou que a rejeição categórica do arbítrio não poderia ser conservada intacta ao lado dos outros dois imperativos políticos centrais. Assim, embora a rejeição do arbítrio seja reiterada de modo flagrantemente contraditório, Constant é obrigado a aceitar o ato que fez "a Constituição se curvar perante a salvação da República", apostando, contra sua própria formulação teórica, que essa violação da Constituição poderia ser pontual e se justificar pelas circunstâncias extraordinárias em que a França ainda se encontrava. Mais do que como uma questão de caráter, a contradição flagrante de Constant no discurso do 30 Frutidor é interpretada aqui como um resultado da interação entre o equilíbrio teórico precário e a prática política.

Segundo a interpretação aqui desenvolvida, a contradição resultante desse primeiro choque entre a teoria e a prática políticas é sentida como um problema para o próprio Constant, de modo que o equilíbrio precário com o qual terminamos o Capítulo 1 não pode permanecer estável. Se o discurso do 30 Frutidor é a resposta imediata do autor ao golpe do 18 Frutidor, ele logo percebe que a prova do evento exige uma resposta mais refletida, a qual será elaborada ao longo dos anos seguintes. Nessa resposta mais refletida, a rejeição categórica do arbítrio precisa ser repensada, uma vez que o evento provou que mesmo um autor que rejeita o arbítrio pode se ver constrangido a apoiá-lo quando o 
governo republicano não consegue se manter independente da opinião pública monarquista por outro meio. Em vez de banido, o arbítrio passa a ser incorporado à vida política de modo controlado.

Nesse esforço de reformular sua teoria para repensar o arbítrio, Constant não está sozinho. O golpe do 18 Frutidor foi sentido como um problema a ser respondido teórica e politicamente por todo o seu entorno político-intelectual. No fundo, o espetáculo de uma República recorrendo a meios arbitrários para se salvar de um alegado perigo contrarrevolucionário que usa como meio a própria soberania popular coloca em alerta toda a elite política termidoriana, a qual passa a pensar em como evitar espetáculos como esse. O medo de a República ser derrubada pela soberania de um povo não republicano, ou pelas medidas arbitrárias utilizadas para impedir isso, passa a assombrar os espíritos. Nas respostas ao 18 Frutidor formuladas nos anos que se seguem ao evento, é comum a necessidade do arbítrio ser reconhecida de alguma forma, de modo implícito ou explícito. Assim, a resposta amadurecida de Constant ao 18 Frutidor não deve ser considerada apenas em relação a sua resposta imediata ao evento em 30 Frutidor, mas também como uma continuidade e uma crítica às respostas avançadas por pessoas como Roederer, Bonaparte, Staël, Sieyès, Cabanis e Necker. Na visão de Constant, todos esses autores incorporam o arbítrio à vida política de modo mais ou menos assumido, mas nenhum deles preveniu devidamente a degeneração do arbítrio em tirania.

\subsection{Do revisionismo constitucional à Constituição do Ano VIII e a sua crítica por Necker: as reações ao 18 Frutidor no entourage de Constant}

Como afirma Gueniffey, um dos primeiros efeitos do golpe do 18 Frutidor foi conferir um novo impulso às correntes revisionistas que criticavam a Constituição de 1795 desde sua elaboração. "Parecia ter chegado o momento de reformar a Constituição, aproveitando-se das circunstâncias" (GUENIFFEY, 2008, p. 119-120). O já citado artigo de Mathiez explora diversos planos de reforma constitucional que passam a circular nos bastidores políticos após o 18 Frutidor, destacando-se nessas conspirações as figuras de Saint-Simon, Barras, Talleyrand, Staël, Constant, Sieyès e Bonaparte. Na leitura de Mathiez, esses planos, essencialmente autoritários, já anunciam o 18 Brumário: o objetivo comum dos conspiradores seria "a criação de um governo forte, estável e conservador" 
(MATHIEZ, 1929, p. 17), o qual retiraria o poder da representação nacional. Gueniffey (2008, p. 120-143) enfatiza o papel de Barras na articulação desse grupo revisionista e da dupla Staël-Constant na formulação das alternativas constitucionais.

Todavia, nem Mathiez nem Gueniffey mencionam o fato de que um dos primeiros a vir a público (não a conspirar nos bastidores) com um programa de reforma constitucional após o 18 Frutidor foi justamente um dos principais críticos da nova Constituição em 1795: Roederer. Poupado por pouco das proscrições do 18 Frutidor, ${ }^{52}$ o autor vê no evento a oportunidade para relançar, de modo mais agressivo, sua ofensiva contra a Constituição do Ano III e pelo fortalecimento do Poder Executivo. No tomo V do Journal d'économie publique, de morale et de politique (de 1797), após transcrever os comunicados e medidas oficiais decretados pelo Diretório em 18 Frutidor, Roederer publica um artigo intitulado "Du parti qu'il est possible de tirer des événements du 18 fructidor pour la chose publique".

Nesse artigo, Roederer relembra as críticas à Constituição do Ano III expostas por ele em Du Gouvernement, de 1795 (ver a Seção 1.2 desta tese). Para o autor, o golpe do 18 Frutidor prova a correção de sua principal crítica à Constituição de 1795 - a fraqueza do Poder Executivo, o qual não encontraria na Constituição meios legais de se defender de um Legislativo invasor:

\begin{abstract}
Os eventos dessa jornada provam que o Diretório e a maioria dos Conselhos acreditaram em uma contrarrevolução iminente, quiseram preveni-la e viram a Constituição como insuficiente para esse fim. Parece-nos evidente que, se o Diretório tivesse encontrado na Constituição meios simples e seguros de dissipar os temores que o atormentavam, assim como a muitos bons cidadãos, ele não teria buscado fora dela meios tristes e perigosos, e que a força não foi, nessa circunstância, outra coisa para ele do que um substituto da lei (ROEDERER, 1796-1797, V, p. 247-248).
\end{abstract}

Assim, Roederer aceita o golpe do 18 Frutidor como necessário devido à impossibilidade de conter a ameaça contrarrevolucionária pelos meios disponíveis na Constituição de 1795. Não obstante, ao contrário de Constant em 30 Frutidor, o obstáculo enfatizado não é a ameaça contrarrevolucionária em si mesma, mas antes as falhas da Constituição de 1795. Desse modo, Roederer é um dos primeiros a responder ao 18 Frutidor com uma proposta de reforma constitucional, apresentada como a única forma de impedir a necessidade de novos golpes.

${ }^{52}$ Roederer estava na lista inicial dos 54 escritores ou jornalistas a deportar, mas Talleyrand conseguiu, não sem dificuldade, convencer o Diretório a retirar seu nome. 
Essa reforma constitucional não é outra coisa do que seu programa de 1795 , apresentado de modo menos tímido. A primeira emenda seria o direito de veto do Executivo, insinuado em 1795, mas ainda não defendido explicitamente naquela ocasião, por não haver um clima favorável a essa ideia apenas três anos após a abolição da monarquia (embora Lezay-Marnésia já tivesse defendido o veto executivo em Qu'est-ce que la Constitution de 95 ?). A segunda emenda seria a imposição de três meses de férias por ano ao Legislativo, deixando ao Diretório a faculdade de determinar os períodos de realização dessas férias, de uma só vez ou por partes. Desse modo, o governo conseguiria manejar os momentos em que as assembleias são tomadas por intrigas e paixões. A terceira emenda seria a gradação de funções públicas, de modo que ninguém poderia chegar ao Conselho dos Anciões sem ter passado antes pelo Conselho dos Quinhentos ou pelas assembleias nacionais precedentes; ao Conselho dos Quinhentos sem ter sido antes juiz ou administrador de departamento; a um tribunal ou administração de departamento sem ter sido antes oficial municipal ou juiz de paz. Essa medida afastaria das eleições seguintes quase todos os candidatos perigosos, favorecendo um Legislativo composto por pessoas sábias e bem-intencionadas. A quarta emenda seria a obrigação de que os diretores fossem escolhidos entre os membros do Conselho dos Anciões, retornando a esse Conselho após seu mandato no Diretório por mais três anos, podendo depois ser reeleitos ao Diretório. Tratava-se da principal proposta de Roederer em 1795, visando a estreitar os laços entre os poderes Executivo e Legislativo e a garantir alguma influência do primeiro sobre o segundo (cf. p. 67 supra). A quinta emenda seria a inviolabilidade dos diretores, havendo sobre os ministros uma responsabilidade precisa reduzida a quatro casos bem especificados: a violação da liberdade do Legislativo, da imprensa ou das eleições e a dilapidação das finanças. Roederer critica a ausência de garantia judiciária dos diretores na Constituição de 1795, os casos de responsabilidade não sendo determinados com precisão na Constituição, de modo que "depende das paixões estender essa responsabilidade arbitrariamente" (ROEDERER, 1796-1797, V, p. 258). A sexta emenda seria uma centralização administrativa que colocasse os administradores locais em uma dependência mais forte em relação ao governo central, inclusive no que diz respeito à nomeação dos membros dos conselhos de administração local. Como em 1795, o autor critica a fraqueza de um governo que encontra "conselhos e corporações por toda parte onde ele só precisaria de agentes de execução; deliberações, onde ele só precisaria de obediência; homens dos governados, onde só deveria haver homens do governo" (ROEDERER, 1796-1797, V, p. 261). Por fim, Roederer sugere a necessidade de uma 
mudança constitucional que assegurasse a unidade da vontade governamental, criticando a divisão e a instabilidade resultantes da renovação de um membro do Diretório a cada ano. Porém, o autor não precisa nesse caso a revisão constitucional a adotar, contentandose em expor várias propostas que estariam circulando sem apoiar nenhuma em particular, retomando um debate já exposto em sua brochura de 1795.

Como já tratado no Capítulo 1, é comum a interpretação de Roederer como um precursor do autoritarismo napoleônico - pense-se sobretudo na categoria "autoritarismo liberal", aplicada por Jainchill principalmente a Roederer e Sieyès (JAINCHILL, 2008, Cap. 5). Entretanto, no Capítulo 1, nós já sublinhamos que a proposta constitucional elaborada por Roederer em 1795, reapresentada agora em 1797 de modo menos tímido, mas com as mesmas linhas gerais, não era explicitamente autoritária. Embora a ênfase recaísse sobre o fortalecimento do Poder Executivo, esse Executivo não seria dotado de poderes extraordinários. Em certo sentido, ele permanece mais fraco e menor em importância do que o Poder Executivo das democracias contemporâneas. O que interessa sublinhar aqui na proposta de Roederer de fortalecimento do Executivo é sua argumentação, retomada de 1795 e do raciocínio de Necker, segundo a qual a faculdade do governo de tomar decisões independentes não levanta o problema do arbítrio. Como havia feito em 1795, o autor adianta a possível objeção de que ele estaria tornando o Executivo forte demais e, portanto, perigoso para a liberdade, dando à objeção hipotética a mesma resposta de dois anos atrás: sendo um órgão de ação e não de vontade, não é da natureza do Executivo usurpar as funções do Legislativo. Os meios postos à sua disposição só são usados para se defender do Legislativo, e a principal garantia do Legislativo são os meios que dão ao Executivo uma sensação de segurança:

\footnotetext{
Responderemos, como o fizemos no Ano III, que, em princípio, a garantia do Poder Legislativo contra o Poder Executivo só pode e só deve ser moral. Que ela só pode e só deve consistir em duas coisas: o direito de apelo ao povo, em caso de excesso do Poder Executivo, e a inutilidade de todo excesso, por parte do Poder Executivo, para se manter. O Parlamento da Inglaterra não tem outra garantia contra o Rei além da confiança pública e da segurança do Rei contra o Parlamento. Como o Rei pode opor seu veto e sua inviolabilidade a todos as maquinações das facções, ele não tem nenhuma necessidade de seu exército para se defender, contanto que essas duas prerrogativas não sejam diretamente atacadas (ROEDERER, 1796-1797, V, p. 259).
}

Assim, se Roederer prega um fortalecimento do Poder Executivo, é com o raciocínio segundo o qual a própria natureza desse poder torna impossível que a margem de decisão discricionária concedida a ele degenere em um poder arbitrário e tirânico. A única possibilidade de o Executivo agir de modo arbitrário e tirânico reside na situação 
em que ele não tem meios constitucionais de se defender das usurpações do Legislativo, como ocorreu no 18 Frutidor. Portanto, fortalecer o Executivo e lhe conferir uma margem de decisão discricionária constituiria uma garantia para o próprio Legislativo:

\footnotetext{
No fundo, que garantia pode valer para o corpo legislativo a inexistência, a impossibilidade de qualquer interesse, por parte do governo, em atentar contra os seus direitos? Propor uma garantia forte do Poder Executivo não é, portanto, de modo evidente, trabalhar para o Poder Legislativo? (ROEDERER, 17961797 , V, p. 260).
}

Essa crença de que um Poder Executivo seguro de si mesmo não invade o Legislativo devido a sua própria natureza faz com que Roederer prescinda da figura de um "guardião da Constituição" externo aos poderes Legislativo e Executivo - como o júri constitucional proposto por Sieyès em 1795, o qual ronda as respostas ao 18 Frutidor posteriores a essa de Roederer, como veremos. Em certo sentido, o autor atribui ao próprio Executivo a guarda da Constituição, embora o termo não seja utilizado. Deveria caber ao Executivo vetar as leis contrárias à Constituição (ROEDERER, 1796-1797, V, p. 253), assim como intervir nos momentos em que o Legislativo é tomado por intrigas e paixões, impondo-lhe férias. Essas funções de guarda da Constituição colocam à mão do Executivo uma faculdade de decisão discricionária que rompe com o legicentrismo revolucionário tratado no Capítulo 1, o qual havia feito do Executivo um simples aplicador da lei. No entanto, esse arbítrio à disposição do Executivo não levanta para Roederer o problema de como evitar a degeneração do arbítrio em tirania, pois as premissas do liberalismo da ordem representado pelo autor afastam a possibilidade de um Executivo tirânico, salvo nos casos em que ele se sente ameaçado pelo Legislativo e sem meios constitucionais de se proteger.

Todavia, se o problema do arbítrio é simplesmente contornado no desenho constitucional proposto por Roederer em resposta ao 18 Frutidor, ele não tem como deixar de aparecer no que diz respeito aos meios de pôr em prática esse desenho constitucional, em substituição à Constituição formalmente em vigor. A Constituição de 1795 havia tornado especialmente difícil e demorada sua modificação por vias legais, toda mudança devendo ser aprovada pelos dois Conselhos durante nove anos seguidos, depois devendo ser aprovada por uma assembleia especial e, por fim, pelo voto popular. Propor uma revisão imediata da Constituição em resposta às circunstâncias, como Roederer estava fazendo, era sugerir um procedimento visivelmente inconstitucional, e o autor precisava justificar essa sugestão ousada. Sua justificativa é que a Constituição acabava de ser violada a fim de salvá-la, só podendo entrar novamente em vigor de modo pleno se fossem 
feitas as correções que impediriam novas violações constitucionais no futuro próximo: "Sem dúvida, a Constituição ainda existe, mas sua inviolabilidade não existe mais, pois ela foi afastada para salvar a própria Constituição. Não se pode restabelecê-la sem estabelecer na Constituição os meios de preservá-la" (ROEDERER, 1796-1797, V, p. 250). Nesse contexto de crise, seria necessário se ater ao espírito da Constituição, mais do que a sua letra. O procedimento de revisão constitucional de nove anos teria como finalidade prevenir as instabilidades constitucionais, mas a instabilidade já estaria dada como resultado da violação constitucional que foi o golpe do 18 Frutidor. “(...) e uma revisão que tivesse por objeto os artigos ou as lacunas interpretados como causas de transgressões não seria, por essa razão, um remédio necessário para a instabilidade atual, em vez de ser uma causa de instabilidade para o futuro?” (ROEDERER, 1796-1797, V, p. 250). Assim, o único ato propriamente arbitrário proposto explicitamente por Roederer, a revisão constitucional fora do caminho traçado pela Constituição, é justificado pela excepcionalidade das circunstâncias e pelo fato de a Constituição ter acabado de ser violada. De resto, a primeira resposta do liberalismo da ordem ao 18 Frutidor não faz da incorporação institucional do arbítrio uma questão, atribuindo poderes discricionários limitados ao Poder Executivo e conferindo a ele um papel análogo ao do guardião da Constituição, mas sem considerar uma possível deriva tirânica desses poderes.

É verdade que, se a proposta constitucional que Roederer expõe ao público ainda não é explicitamente autoritária, propostas mais ousadas começam a circular nos bastidores políticos imediatamente após o 18 Frutidor. Em carta secreta a Talleyrand de 21 de setembro de 1797, Napoleão Bonaparte, respondendo a seu interlocutor sobre o que ele achava da Constituição de 1795, esboça um plano de organização constitucional que já indica muito mais claramente o rumo que a França iria tomar após o 18 Brumário. Bonaparte não se contenta, como Roederer nesse momento, em dotar o Poder Executivo do direito de veto, do de determinar o período de férias do Legislativo e da inviolabilidade. Em seu plano constitucional, o governo se apodera do essencial da atividade legislativa, incluindo aí o direito de guerra e paz e o de determinar os impostos. Mais do que de aumentar as prerrogativas do Executivo, trata-se, para Bonaparte, de alterar seu status constitucional, tornando-o o verdadeiro representante da soberania popular: "O poder do governo, em toda a latitude que lhe atribuo, deveria ser considerado como o verdadeiro representante da nação" (BONAPARTE, 2004, p. 1197). O governo seria dividido em duas magistraturas distintas, o Diretório executivo propriamente dito e 
um "grande conselho da nação" que o vigiaria e enquadraria (BONAPARTE, 2004, p. 1197). O Poder Legislativo se tornaria “sem posição na República, impassível, sem olhos nem orelhas para o que o cerca, não teria ambição e não nos inundaria mais com mil leis de circunstância que se anulam sozinhas por seu caráter absurdo" (BONAPARTE, 2004, p. 1197). Em suma, na pena de Bonaparte em 1797, já se esboça o deslocamento do Executivo guardião da Constituição para o Executivo centro do poder. E esse deslocamento é apresentado como uma consequência direta do 18 Frutidor, que demonstrou a impossibilidade de a Constituição do Ano III se manter sem recorrer às baionetas:

Eis, creio, um código completo de política, que as circunstâncias em que nos encontramos tornam perdoável. É uma infelicidade tão grande, para uma nação de trinta milhões de habitantes, e no século XVIII, ser obrigada a recorrer às baionetas para salvar a pátria! Os remédios violentos acusam o legislador (BONAPARTE, 2004, p. 1197).

Não à toa, Gueniffey considera algumas proposições de Bonaparte como próximas do grupo dos revisionistas articulado por Barras e que envolvia naquele momento Staël e Constant, mas pondera que "a importância que ele conferia ao Poder Executivo, e o papel mais do que subordinado que ele atribuía ao Parlamento, mantinham-no tão afastado deles quanto da maioria dos revolucionários" (GUENIFFEY, 2008, p. 159-160).

Se a resposta ao 18 Frutidor que Bonaparte confidenciava a Talleyrand era das mais ousadas, uma das mais sofisticadas intelectualmente pode ser encontrada em Des circonstances actuelles qui peuvent terminer la Révolution et des principes qui doivent fonder la République en France, escrito por Madame de Staël em 1798, e publicado apenas em 1906. O fato de Constant ter participado da revisão desse texto em 1799, até hoje não se sabendo ao certo o peso que ele teve na redação do livro, torna essa obra de Staël uma via de acesso às ideias que estavam rondando nosso autor nessa época. Não obstante, apesar da proximidade entre Staël e Constant, nessa época amantes e no auge de sua colaboração intelectual, a posição de Staël na constelação de ideias políticas que vem sendo tratada nesta tese era ligeiramente diferente.

Se, no Capítulo 1, nós abordamos o jovem Constant por meio de sua oposição ao que chamamos de "liberalismo da ordem", Staël pode ser considerada como estando, durante o Diretório, a meio caminho entre as duas posições, esforçando-se, em geral, para 
conciliá-las. ${ }^{53}$ Filha de Necker, ela buscou ao longo de toda a Revolução Francesa aumentar a força do Poder Executivo, ${ }^{54}$ posicionando-se em 1789 a favor do direito de veto absoluto do Rei, e depois, na impossibilidade do veto absoluto, do veto temporário como o substituto possível (FONTANA, 2016, p. 22-24). Em "À quels signes peut-on connaître quelle est l'opinion de la majorité de la nation ?", artigo publicado em agosto de 1791 (após a fuga de Varennes), a autora defende a manutenção da autoridade legal e da força legítima de um monarca como meio de garantir a ordem ao lado da igualdade e da liberdade (STAËL, 2009, p. 562).

A partir de 1795, quando Staël retorna a Paris na companhia de Constant, sua adesão ao regime republicano ${ }^{55}$ provoca um afastamento em relação ao programa político de seu pai. No entanto, a República que ela busca se aproxima em larga medida da de Roederer, um amigo próximo a quem ela escreve em 1797 ser "o pensador mais profundo que conheço", prometendo que "jamais eu desviarei da linha que você me parece seguir mais exatamente do que qualquer outro" (STAËL apud ROEDERER, 1853-1859, vol. 8, p. 655; cf. p. 73 supra). Ora, no Capítulo 1, nós caracterizamos o projeto termidoriano de Roederer e Lezay-Marnésia como a adaptação do liberalismo da ordem esboçado por Necker a um quadro republicano que se reivindica herdeiro da Revolução Francesa. Assim, Staël via com simpatia esse projeto, e sua proposta constitucional de 1795, elaborada sobretudo nas Réflexions sur la paix intérieure, dialoga com as ideias constitucionais propostas por Roederer no mesmo momento - sendo ambos derrotados pelo projeto constitucional aprovado pela Convenção. Como Roederer, ela critica a fraqueza do Poder Executivo no projeto constitucional da Comissão dos Onze, propondo que o Executivo participe da confecção da lei por meio de um veto revisor (STAËL, 2009, p. 151). Em carta a Roederer de 9 de junho de 1795, a autora sugere que, na ausência do direito de veto, o Executivo poderia influenciar o processo legislativo se os ministros fizessem parte da câmara alta (STAËL apud ROEDERER, 1853-1859, vol. 8, p. 646) -

${ }^{53}$ Como mencionado no Capítulo 1, Staël tenta aproximar Constant de Roederer pedindo a este uma resenha de Des réactions politiques em 1797, mas o editor do Journal d'économie publique frustra as expectativas de sua amiga, publicando uma resenha agressiva contra Constant (cf. p. 73 supra).

${ }^{54}$ Sobre a trajetória político-intelectual de Staël durante a Revolução Francesa, ver especialmente: FONTANA, 2016.

55 "Está-me demonstrado que, nas circunstâncias atuais, apenas o governo republicano pode dar repouso e liberdade à França” (STAËL, 2009, p. 628). Essa frase, publicada por Staël em “Aux rédacteurs des Nouvelles Politiques", em 3 de junho de 1795, marca sua conversão oficial ao republicanismo. 
uma ideia que Roederer incorpora a seu projeto constitucional em Du Gouvernement, como vimos no Capítulo 1 (cf. p. 67 supra). Por trás do raciocínio, estava presente a visão de Necker sobre o modelo inglês, segundo a qual a realeza e a Câmara dos Lordes estão em constante comunicação, apoiando-se mutuamente e garantindo a preservação da ordem ao lado da liberdade. Assim, já nas Réflexions de 1795, Staël acena para a compreensão do Conselho dos Anciões como um "poder conservador" cuja força deveria ser aumentada:

(...) quanto mais apoiarmos os diversos meios de aumentar a duração, a força e a consideração da Câmara dos Anciões, mais quereremos dar consistência ao poder conservador que deve existir em todas as constituições, para responder por sua duração, mais nos mostraremos partidários úteis da manutenção da Constituição de 1795 (STAËL, 2009, p. 163; ênfase nossa).

Como Roederer, Staël responde ao 18 Frutidor com uma retomada de suas críticas à Constituição de 1795 e a elaboração de um projeto constitucional alternativo, apresentado no Capítulo 1 da Segunda Parte ("De la Constitution") de Des circonstances. É verdade que a reforma constitucional era apenas uma parte da resposta, a autora acreditando, como Constant no discurso de 30 Frutidor, que o verdadeiro enraizamento da República deveria ser construído no plano cultural, como trataremos a seguir. Foquemos, por ora, o argumento da revisão constitucional. Como Roederer, Staël entende que o 18 Frutidor constituiu uma ruptura constitucional que autoriza uma revisão da Constituição fora do caminho de nove anos traçado por ela, sem o que a França permanecerá sem Constituição apesar de ter uma formalmente em vigor: “Assim, ainda não existe Constituição na França, porque nem a liberdade, nem a igualdade, nem a felicidade estão ainda estabelecidas" (STAËL, 2009, p. 407).

Todavia, a reforma constitucional proposta por Staël visa a responder a um problema mais profundo do que a de Roederer. Para este, a Revolução Francesa já tendo terminado (ver Capítulo 1), o problema a ser solucionado se resumia a um desequilíbrio de forças entre os poderes Legislativo e o Executivo. Staël, embora compartilhando esse diagnóstico sobre a fraqueza do Poder Executivo, via-se diante de um problema mais profundo, compartilhado com Constant: o problema de como manter uma República ainda não enraizada na opinião pública, enquanto ela ainda não tivesse derrotado uma reação política engendrada pelos excessos da própria Revolução. Seu diagnóstico de que a República havia sido fundada antes que a opinião pública estivesse preparada para ela ecoa a preocupação de Constant de que as instituições estejam em sintonia com as ideias 
de uma época, sem o que há revolução ou reação. ${ }^{56}$ Como Staël compartilhava com Constant a visão de que a Revolução Francesa ainda não havia terminado, a República ainda não estando estabelecida na opinião pública e precisando vencer um espírito de reação, ela compartilhava com seu amante a preocupação com a independência do governo republicano em relação à maioria nacional, traduzida em um monopólio do poder pelo partido republicano:

(...) o poder não pode sair do partido republicano. (...) A República só pode avançar pelo partido republicano, e o que nos perdeu antes do 18 Frutidor foi a ideia de que opiniões resignadas poderiam sustentar uma instituição ainda atacada por tempo demais, para que não precisasse de uma grande energia para sustentá-la (STAËL, 2009, p. 357).

Assim, a reforma constitucional de Staël é mais profunda do que a de Roederer por enfrentar o problema de como manter a independência do governo republicano em relação à maioria nacional sem renunciar formalmente ao princípio da soberania do povo. No Capítulo 1, nós analisamos como, nos primeiros escritos de Constant, essa questão fazia o problema do arbítrio emergir de modo agudo, sua resposta sendo a rejeição radical do arbítrio. Com o 18 Frutidor, o arbítrio é admitido como necessário, aparecendo na prática política de Constant como o retorno do que havia sido recalcado na teoria. No livro de Staël de 1798 (cuja escrita é acompanhada de perto por Constant, vale lembrar), nossa hipótese é que há uma primeira tentativa de, perante a necessidade de apelar ao arbítrio, incorporá-lo ao sistema institucional de modo controlado e provisório.

A pedra angular dessa incorporação controlada e provisória do arbítrio reside no resgate do "poder conservador" em que Staël queria transformar o Conselho dos Anciões em 1795, mas em uma nova chave, em que esse poder conservador é o meio pelo qual a República permanece sob o comando do partido republicano, mesmo que ele perca as eleições, e sem a necessidade de recorrer a golpes como o 18 Frutidor ou o 22 Floréal: $^{.57}$

56 “Tudo o que se faz de acordo com a opinião é mantido por ela, mas, a partir do momento em que a opinião é precedida ou combatida, é preciso recorrer ao despotismo. A França, em 1789, queria a monarquia temperada. O Terror não foi necessário para estabelecê-la. A República se estabeleceu cinquenta anos antes que os espíritos estivessem preparados para ela: recorreu-se ao Terror para estabelece-la. Mas, longe que esse meio cruel possa fundar o que quer que seja, a reação desse tempo, antes do 18 Frutidor, havia feito as luzes filosóficas recuarem para muito além da primeira revolução" (STAËL, 2009, p. 374).

${ }^{57}$ Em 22 Floréal do Ano VI (11 de maio de 1798), um novo golpe é realizado contra os vencedores da eleição de abril de 1798: dessa vez, os neojacobinos, os quais se tornam os principais adversários do centro republicano após a proscrição dos monarquistas no 18 Frutidor. Diferentemente do 18 Frutidor, no 
“É preciso, na França, até o momento em que a instrução pública tiver formado uma nova geração para a liberdade, é preciso prolongar algumas porções do poder conservador entre as mãos dos republicanos" (STAËL, 2009, p. 374). O modo de tornar o Conselho dos Anciões esse poder conservador sob controle republicano seria torná-lo um órgão não mais eletivo, mas vitalício, composto inicialmente de amigos comprovados da República (membros das assembleias da Revolução Francesa, do Institut national de France, pensadores esclarecidos e militares que se destacaram na guerra), recrutando-se a si mesmo entre os deputados do Conselho dos Quinhentos. Os Quinhentos teriam que formar a lista de candidatos para o Diretório entre os membros desse novo Conselho dos Anciões. Seria esse novo corpo aristocrático e republicano o encarregado por aprovar ou rejeitar as leis propostas pelo Conselho dos Quinhentos, seus membros devendo ser contemplados com uma renda considerável que "lhes assegurasse não somente a independência, mas a consideração atrelada à riqueza" (STAËL, 2009, p. 378). Antecipando a acusação de propor uma instituição aristocrática incompatível com a República e o princípio da soberania do povo, a autora responde: "Sim, trata-se de uma instituição aristocrática, composta dos destruidores e dos inimigos inconciliáveis da verdadeira aristocracia" (STAËL, 2009, p. 376). Os contrarrevolucionários tendo aprendido que "a democracia não se destrói de outro modo que não com os princípios da democracia" (STAËL, 2009, p. 376), seria preciso que os republicanos

(...) adotassem algumas das ideias da aristocracia, para estabelecer solidamente as instituições populares. Os democratas sabem conquistar, ao passo que os aristocratas sabem conservar. Os democratas devem, após seu triunfo, estudar com cuidado os meios dos aristocratas, para adotar todos os que não são preconceitos, mas cálculos (STAËL, 2009, p. 376).

A inspiração da proposta de Staël, evocada explicitamente no texto, é o júri constitucional proposto por Sieyès em 1795 à Convenção e rejeitado por unanimidade. ${ }^{58}$ A função mais importante dessa instituição concebida por Sieyès seria o julgamento de queixas contra atos dos poderes Legislativo ou Executivo acusados de violar a Constituição - função esta que leva Sieyès a afirmar: "Eu dou um conservador, um guardião à Constituição" (SIEYÈS apud TROPER, 2006, p. 414). Entretanto, Staël radicaliza a proposta de Sieyès. Se a Convenção havia rejeitado o júri constitucional com

22 Floréal, o governo não precisou recorrer ao exército, os próprios conselhos revogando a eleição dos novos eleitos (GUENIFFEY, 2008, p. 218).

58 Todo o debate da Convenção sobre o projeto da Constituição de 1795 - no qual foi apresentada e discutida a proposta de júri constitucional de Sieyès - encontra-se transcrito em TROPER (2006, p. 277 698). 
o argumento de que ele poderia se tornar um poder não controlado que dominaria os outros poderes e desequilibraria a República, Staël considera, ao contrário, o poder concebido por Sieyès como fraco demais para proteger a República dos perigos que a rondavam, uma vez que ele só se reuniria intermitentemente para julgar queixas contra atos dos demais poderes, além de dependente demais da opinião majoritária do momento por ser eleito como os demais poderes - quando o que se precisava era justamente de um guardião da Constituição independente da opinião majoritária momentânea, portanto não eleito (STAËL, 2009, p. 375-376).

Em suma, a prova do 18 Frutidor leva Staël a retomar a ideia de Sieyès segundo a qual a Constituição precisa de um guardião, pensando, porém, esse guardião em outro quadro de referências. Ao passo que Sieyès concebe em 1795 seu júri constitucional no interior de "um modelo judiciário do funcionamento político" (GAUCHET, 1995, p. 166), o qual "erige a forma-tribunal em defesa enfim encontrada contra o arbítrio" (GAUCHET, 1995, p. 167), Staël pensa seu corpo conservador pelo modelo da ditadura das instituições: "Vocês precisam escolher entre a ditadura das instituições e a das perseguições, e eu prefiro fortemente a primeira" (STAËL, 2009, p. 374).

No Capítulo 1, vimos que a ditadura foi um dos modelos pelos quais a tradição de pensamento político anterior à Revolução Francesa pensou o problema do arbítrio, entendido como o das situações em que as leis não poderiam se aplicar sem perigo ao corpo político. Esse modelo foi especialmente elogiado na tradição republicana, pelo menos de Maquiavel a Rousseau. Nessa tradição, a ditadura louvada era aquela consagrada pela República Romana, na qual o ditador era nomeado por um curto período para superar algum obstáculo que colocava a República em perigo, estando, durante esse breve intervalo, liberado das interdições normalmente impostas pelas leis. Referimo-nos também, naquele capítulo, à mutação que Schmitt identifica no conceito de ditadura na época da Revolução Francesa, trabalhada em seu livro clássico de 1921, A Ditadura. Da "ditadura comissarial" da tradição republicana, passava-se à "ditadura soberana" amparada no conceito de Poder Constituinte, a qual estava autorizada a querer sem limites e a instituir atos de soberania, na medida em que seu ponto de referência era uma ordem constitucional ainda não instituída (cf. p. 53 supra). Utilizando-se essa distinção proposta por Schmitt, pode-se entender a ditadura das instituições proposta por Staël como a meio caminho entre a ditadura comissarial e a ditadura soberana. No espírito do conceito clássico de ditadura comissarial, caro à tradição republicana, a ditadura proposta por Staël 
tem por finalidade a conservação da Constituição estabelecida, constituindo uma exceção temporária à vida republicana normal justificada pela situação de perigo. Porém, contrariando o modo clássico de conceber a ditadura comissarial, Staël aloca seus ditadores republicanos no interior do Poder Legislativo, fazendo eles participarem da elaboração das leis - algo inconcebível na ditadura romana, tal como caracterizada, por exemplo, por Rousseau, para quem o ditador "tudo pode fazer, exceto ditar leis" (ROUSSEAU, 2006, p. 150; cf. p. 49 supra). Na visão da autora, essa ditadura alocada nas instituições oferece a vantagem de proteger a República da ameaça contrarrevolucionária ou neojacobina, sem a necessidade das perseguições violentas possivelmente associadas ao conceito clássico de ditadura e efetivamente adotadas após o 18 Frutidor: "se há a necessidade de uma ditadura, ou seja, de uma suspensão do exercício da vontade de todos, como não a buscar em instituições legais, em vez de a abandonar a violências arbitrárias?” (STAËL, 2009, p. 384).

Outro aspecto da ditadura das instituições proposta por Staël em 1798 é o fortalecimento do Poder Executivo, o que faz sua proposta constitucional convergir com a de Roederer. Apoiando-se simultaneamente em Necker e Sieyès, a autora defende um sistema de união dos poderes, em que a necessária separação de funções não resulte em um sistema de divisão que torne os poderes inimigos entre si. Nesse sentido, ela retoma sua proposta de veto suspensivo de 1795 e acrescenta o direito de o Diretório dissolver o Conselho dos Quinhentos e convocar uma nova eleição. Tratava-se de radicalizar o direito de o Diretório dar férias ao Legislativo quando este se tornasse perigoso, proposto por Roederer após o 18 Frutidor. O modelo que Roederer e Staël tinham em mente era a monarquia inglesa, com sua faculdade de barrar os extravasamentos do Parlamento por meio da dissolução e da convocação de novas eleições - uma faculdade que evitaria a necessidade de exercer essa contenção dos excessos legislativos por meio de um golpe como o 18 Frutidor: "O 18 Frutidor foi o direito de dissolver o Parlamento da Inglaterra, exercido de modo violento porque não existia um modo legal de realizar essa dissolução e havia uma necessidade positiva dela" (STAËL, 2009, p. 386). Como vimos, para Roederer, a participação do Poder Executivo na "guarda da Constituição" não colocava o problema do arbítrio porque o autor não acreditava na possibilidade de um Executivo usurpador. Já para Staël, a legitimidade dessa faculdade de o governo dissolver o Parlamento e convocar novas eleições se liga à noção de "ditadura das instituições" já referida. 
Segundo a hipótese aqui defendida, Staël adota o vocabulário da ditadura como uma resposta ao teste do 18 Frutidor, o qual lhe demonstra a impossibilidade de manter um governo oriundo da soberania do povo independente da opinião dominante sem recorrer a nenhuma forma de arbítrio, como ela e Constant haviam apostado antes do golpe. Na proposta constitucional da autora, o arbítrio é incorporado ao sistema institucional, na medida em que um corpo conservador não eleito e vitalício passaria a ter o poder de rejeitar a lei oriunda do processo representativo regular sem que essa rejeição precisasse se basear em uma inconformidade da lei em questão com a Constituição (como no modelo judiciário de Sieyès e no atual controle de constitucionalidade), mas apenas em considerações discricionárias desse corpo conservador a respeito do que é bom ou não para a República. Analogamente, um Diretório formado a partir desse corpo conservador e em sintonia com ele teria o direito de dissolver discricionariamente o Poder Legislativo quando julgasse que os deputados eleitos pelo povo poderiam colocar em risco a República. Contudo, trata-se de uma incorporação do arbítrio em forma domesticada, no sentido de que ele não se manifestaria mais na forma de violências e violações de direitos. Em primeiro lugar, ele não se aplicaria mais a pessoas particulares, prendendo-as, deportando-as etc. Em segundo lugar, os resultados das eleições passariam a ser rigorosamente respeitados - mesmo que a influência desses resultados sobre a marcha dos negócios públicos se encontrasse significativamente reduzida (ou antes, precisamente porque a influência das eleições sobre os negócios públicos seria reduzida que elas poderiam passar a ser respeitadas sem risco para a República).

Porém, como garantir que esse arbítrio à disposição do poder conservador não desequilibrasse a República e se tornasse vetor de tirania? Se, em 1795, o júri constitucional de Sieyès havia sido considerado pelos convencionais um risco à República, o que a elite política e intelectual francesa pensaria desse poder conservador muito mais poderoso? As garantias fornecidas por Staël, em geral de modo implícito, são duas. Em primeiro lugar, o poder conservador seria composto de amigos comprovados da República, o que garantiria que eles não usariam os poderes discricionários colocados em suas mãos para derrubar o regime republicano. Mas a principal garantia seria aquela inerente ao conceito schmittiano de ditadura comissarial: tratar-se-ia de um arranjo provisório, de uma limitação temporária da liberdade política plena, ainda que sua duração não seja delimitada de antemão, como ocorria na ditadura romana. "Vocês poderão democratizar a Constituição à medida que o espírito público fizer progressos" 
(STAËL, 2009, p. 374). Assim, a despeito da importância atribuída pela autora à reforma constitucional, as instituições propostas por ela não seriam mais do que meios de proteger o povo de si mesmo enquanto ele ainda não estivesse totalmente esclarecido e preparado para a liberdade política plena. Como Constant no discurso de 30 Frutidor, Staël aposta que o verdadeiro enraizamento da República depende de uma guerra cultural destinada a apagar os costumes legados pelo passado monárquico da França. Apenas enquanto essa guerra cultural não tiver sido totalmente vencida pelos republicanos, estes precisarão apelar a meios extra-eleitorais para manter a República sob sua direção.

Entre os meios culturais de consolidação da República, Staël destaca, no Capítulo 2 da Segunda Parte de Des circonstances, a mudança de religião: “as repúblicas só podem suceder às monarquias por uma mudança de religião" (STAËL, 2009, p. 414). Como Robespierre em 1794 e La Révellière-Lépeaux logo após o golpe do 18 Frutidor, a autora acredita que a República precisa do apoio de uma religião cívica para criar raízes nos costumes dos cidadãos, reatando assim com outro tema central que percorre a tradição republicana pelo menos de Maquiavel a Rousseau. Seu único distanciamento em relação à temática revolucionária da religião cívica, tal como ela aparece em uma linha que vai pelo menos de Robespierre a La Révellière-Lépeaux, consiste na crítica a certo artificialismo percebido na teofilantropia pregada por La Révellière-Lépeaux, e implicitamente também no culto do Ser Supremo instituído por Robespierre. Segundo Staël, o alcance da teofilantropia é limitado em seu objetivo de preparar os costumes dos cidadãos para a liberdade republicana, pois ela é percebida pelo povo como uma mera seita política, mais do que como uma crença verdadeira. Por isso, ela prefere que a República francesa adote como religião oficial o protestantismo, considerado por ela como muito mais favorável à liberdade, à igualdade e à razão do que o catolicismo, mas dispondo, ao contrário da teofilantropia, da força moral de uma religião verdadeira, concebida à distância das intrigas de partido.

Ainda no plano da "guerra cultural”, Staël prega, no Capítulo 3 da Segunda Parte de Des circonstances, a supervisão dos jornais pela autoridade pública, com o argumento de que, diferentemente dos livros, que exercem a função de propagar ideias, os jornais têm o potencial de preparar ações imediatas, constituindo um perigo para a ordem estabelecida. Entretanto, a autora acredita que cabe principalmente aos escritores esclarecidos terminar a Revolução Francesa, disseminando as luzes necessárias para sustentar a República trazida antes do tempo: "Foram os filósofos que fizeram a 
Revolução, serão eles que a terminarão" (STAËL, 2009, p. 435). Nisso, ela retoma um tema presente no discurso de Constant de 30 Frutidor, que havia celebrado os homens de letras como os verdadeiros criadores da liberdade. Para Constant, os filósofos é que teriam esclarecido os militares, permitindo que suas ações internas e externas à França tivessem como mote a liberdade:

Ah! Não esqueçam jamais que, para que as vitórias sejam úteis, é preciso que
elas sejam precedidas pelas luzes. Que, sob os generais de Luís XIV, a espécie
humana não ganhou nem em felicidade nem em dignidade, e que, se Bonaparte
fez Roma tremer, foi porque Voltaire veio antes de Bonaparte (CONSTANT,
1964, p. 124).

Em 30 Frutidor, Constant celebrava o Cercle constitutionnel como uma "união composta de guerreiros valorosos e escritores esclarecidos" (CONSTANT, 1964, p. 124), uma "aliança entre a força e a razão" (CONSTANT, 1964, p. 124) empenhada em fazer triunfar a República. Seria a união com os filósofos que impediria os militares de se deixar influenciar pelo "espírito de corpo" e pelos hábitos tirânicos próprios a sua corporação, tornando-os guardiões da liberdade. Staël raciocina da mesma maneira em Des circonstances, apontando o espírito militar como um risco à República francesa, mas procurando moderar esse risco colocando os militares sob a direção dos escritores esclarecidos. O Institut national de France, criado em 1795, é, assim, apontado como a instituição que deve gozar da maior consideração no país, constituindo uma espécie de poder espiritual em associação com o poder efetivo. "Pela natureza da Revolução Francesa, é o corpo de homens esclarecidos que deve conservar seus verdadeiros princípios e os dirigir. Ao valorizar sua recepção pelo Institut, Bonaparte mostrou à opinião pública seu verdadeiro caminho" (STAËL, 2009, p. 447). A autora elenca Condorcet, Sieyès, Roederer e Godwin, na geração anterior, assim como Constant, na nova, como os filósofos cujas luzes permitiriam encerrar a guerra atual, a qual tem por objeto a ciência política (STAËL, 2009, p. 439-441), consolidando assim a República: “eis os homens de Estado para a Revolução Francesa” (STAËL, 2009, p. 441).

Os meios "culturais" de terminar a Revolução Francesa e enraizar a República (nova religião oficial, supervisão dos jornais pela autoridade pública, poder espiritual dos filósofos) permitem situar em sua justa medida a "ditadura das instituições" proposta por Staël como resposta ao 18 Frutidor. A incorporação controlada do arbítrio em instituições como o Conselho dos Anciões transformado em poder conservador não era um aspecto de "um sistema político fundado sobre a limitação do poder e as garantias legais", o que Fontana (1994, p. 131-132) acredita ser o objeto de Des circonstances. Pelo contrário, era 
o aspecto de um arranjo provisório em que o partido republicano (militares sob a direção de escritores esclarecidos), declaradamente em guerra contra uma parte da França que ainda não havia aceito a República, deveria tutelar as instituições republicanas antes que elas pudessem operar por si mesmas sem perigo. Como afirma Gueniffey, Staël "não pretendia, portanto, propor um modelo político que fosse o melhor possível para a República, mas um sistema que permitisse a esta última atravessar a difícil prova da 'prélegitimidade"” (GUENIFFEY, 2008, p. 142). Compreende-se, assim, que o livro de Staël, embora não publicado em vida, tenha exercido certo fascínio sobre o público influente que o leu, servindo como uma referência para os revisionistas constitucionais e já anunciando “"o programa de Brumário', uma resposta aos impasses do regime do Ano III" (GUENIFFEY, 2008, p. 143). Contudo, compreende-se também que não tenha sido exatamente esse o programa adotado pelos brumarianos: obcecados por terminar a Revolução por meio de uma Constituição enfim definitiva, o programa de uma "ditadura das instituições" provisória não parecia dos mais atraentes. A mesma obsessão pela Constituição definitiva parece ter afastado o Constant do Consulado do projeto de sua amante, o qual ele havia acompanhado de perto e possivelmente ajudado a formular. Além disso, o golpe do 18 Brumário, que será abordado a seguir, contribui para esfacelar esse "partido republicano" coeso com o qual Staël contava para dirigir sua ditadura - o qual uniria sob a mesma bandeira figuras como Bonaparte, Sieyès, Roederer e Constant. De todo modo, o problema de como incorporar o arbítrio ao sistema institucional para proteger a República de si mesma apenas se aprofunda a partir de então. ${ }^{59}$

${ }^{59}$ Cabe observar que, em Des circonstances, o arbítrio é incorporado ao sistema institucional na forma da "ditadura das instituições" necessária enquanto a Revolução não estiver terminada e a República consolidada, porém sem implicar uma reformulação da noção de império da lei passível de incorporar o arbítrio como possível meio de suavização de leis tirânicas ou excessivas. Essa reformulação da noção de império da lei será empreendida por Constant nos Principes de politique de 1806, como argumentaremos no Capítulo 3. Na perspectiva de Staël em Des circonstances, a própria possibilidade de leis tirânicas é negada em um país sem privilégios ou proscrições: "Só se deve temer leis tirânicas em um país onda possa existir um privilégio ou uma proscrição. O privilégio e a proscrição são erros sociais absolutamente do mesmo gênero, pois, em ambos os casos, trata-se de subtrair alguns cidadãos à lei, seja ao entregar uma classe ao arbítrio da pena, seja ao conceder a uma classe o arbítrio do favor. Não se deve temer leis tirânicas em um país onde todos os cidadãos são igualmente submetidos à lei. (...) A partir do momento em que a lei foi tornada comum a todos, tem-se a garantia da benevolência da lei” (STAËL, 2009, p. 459). Como veremos no Capítulo 3, será contrariando esse postulado, inspirado essencialmente em Rousseau, que 
Cerca de um ano após a escrita de Des circonstances, o golpe do 18 Brumário do Ano VIII (9 de novembro de 1799) joga enfim uma pá de cal no regime instituído em 1795, visto como a cada dia mais insustentável desde o 18 Frutidor. Como se sabe, o principal organizador do golpe não foi ninguém mais ninguém menos do que um dos inspiradores do revisionismo constitucional pós-18 Frutidor, o ex-abade Sieyès, dotado então de imenso prestígio como formulador de constituições. Em 1799, a espada de Bonaparte propiciava enfim a Sieyès a oportunidade que lhe escapara em diversos momentos da Revolução Francesa, especialmente em 1795: oferecer uma Constituição à França, com base na ciência política que ele reivindicava ter completado (cf. JAINCHILL, 2008, p. 213). Na realidade, a história foi mais complexa, pois Bonaparte não se mostrou satisfeito com o complexo plano constitucional formulado pelo ex-abade, no qual o general deveria se contentar com o papel pouco efetivo de "Grande Eleitor". Após dias de negociações envolvendo, além do "sábio" e do militar, figuras como Roederer, Boulay de la Meurthe e Daunou, o projeto de Sieyès sofre mudanças importantes, mantendo, porém, algumas de suas linhas mestras, sendo adotado como Constituição em 13 de dezembro de 1799 (22 Frimário do Ano VIII).

O projeto constitucional de Sieyès e a Constituição do Ano VIII efetivamente adotada serão considerados aqui como uma quarta resposta ao golpe do 18 Frutidor. Com efeito, assim como as propostas constitucionais elaboradas por Roederer, Bonaparte e Staël após o 18 Frutidor, o plano de Sieyès tinha por objetivo central impedir a necessidade de um novo golpe como aquele. Assim como Staël, Sieyès faz da incorporação controlada do arbítrio ao plano institucional um aspecto-chave de seu plano constitucional, com a intenção de impedir a realização do arbítrio por meio de golpes de Estado como o 18 Frutidor. No entanto, o 18 Brumário abre uma nova perspectiva para esse projeto de incorporação controlada do arbítrio, a qual se baseia em uma reformulação radical do conceito de governo representativo.

"Sendo a democracia a base do sistema representativo e do estabelecimento público, o governo elevado sobre essa base não pode se parecer com ela, ele é necessariamente representativo" (SIEYÈS, 1999, p. 519). O ponto de partida do projeto de Sieyès é essa distinção entre democracia e governo representativo, mas em um sentido

Constant radicalizará o problema da incorporação do arbítrio ao império da lei, nos Principes de politique de 1806. 
diferente do que era usual na época, em que a marca distintiva do governo representativo era entendida como sendo a eleição, em oposição à participação direta das repúblicas antigas estabelecidas em pequenas cidades. Para o ex-abade, ao contrário, o governo representativo exclui a eleição: “em um governo representativo, nenhum funcionário deve ser nomeado por aqueles sobre quem deve pesar sua autoridade" (SIEYÈS, 1999, p. 520). Como observa Gauchet, Sieyès elabora seu projeto constitucional em resposta a um contexto em que a instituição da eleição se torna objeto de crise e é colocada em questão - "uma questão não prevista pela teoria, mas dolorosamente ditada pela experiência dos questionamentos anuais do regime a cada retorno do sufrágio" (GAUCHET, 1995, p. 214). Como também observa Gauchet (1995, p. 215-217), Sieyès já havia desenvolvido desde 1789 uma chave teórica da representação que permitia a exclusão da eleição, bastando em 1799 radicalizar esse dispositivo teórico à luz do contexto político. Esse dispositivo teórico era a noção de representação-encarnação, segundo a qual o povo não existe como unidade fora da representação nacional. Ora, em 1799, o ex-abade extrai desse princípio a consequência de que o simples cidadão empírico "não tem o direito de representar o povo, nem o de conferir um poder em seu nome” (SIEYÈS, 1999, p. 520). Apenas o corpo que representa a nação em sua unidade irredutível à coleção empírica de cidadãos poderia nomear as pessoas autorizadas a representar o povo. Ao mesmo tempo, ninguém poderia exercer uma função pública sem contar com a confiança daqueles sobre quem essa autoridade se exerce - eis a base democrática do governo representativo. Sieyès concilia esses dois princípios por meio de seu complexo sistema de "listas de confiança e de notabilidade", o qual separa a formação da representação nacional em duas fases bem distintas. Na primeira, a "democrática", os cidadãos formam espontaneamente listas de cidadãos confiáveis para exercer funções públicas, essas listas sendo depuradas à medida que vão subindo as escalas administrativas (comuna, departamento e nação). Na segunda fase, propriamente eletiva, o corpo que encarna a nação elege, entre os membros das listas de notabilidade, os que serão revestidos de funções públicas e preencherão os poderes da República. “A nomeação dos agentes públicos se fará, portanto, pelos superiores, com base nos quadros apresentados pelos governados: nesse sistema, o poder que ordena a obediência e a disciplina (...) vem de cima, é um poder verdadeiramente nacional" (SIEYÈS, 1999, p. 520). O governo representativo opera assim uma descontinuidade com sua base democrática: ao contrário da concepção usual, a autoridade viria de cima, do poder que encarna a nação em sua unidade, encontrando-se com a confiança que vem de baixo. 
O que é esse poder que encarna a nação em sua unidade? No topo de sua pirâmide constitucional, Sieyès aloca o Colégio dos Conservadores, entendido como "a primeira magistratura na Constituição" (SIEYÈS, 1999, p. 521). Verdadeira figuração da soberania nacional, esse órgão teria, entre várias outras atribuições, a de eleger os membros do Poder Legislativo (dividido no corpo legislativo propriamente dito e em uma "tribuna de petição popular", encarregada de discutir os projetos de lei sem votar), com base nas listas de notabilidade. Para a eleição do Poder Executivo, formado por dois cônsules (um para assuntos interiores, e outro para assuntos exteriores), o responsável seria outro poder, o Grande Eleitor, chamado de "Poder Eleitoral Executivo". O Colégio dos Conservadores e, em menor medida, o Grande Eleitor constituem, na leitura aqui empreendida, a versão sieyèsiana do problema de como incorporar o arbítrio ao sistema institucional após a prova do 18 Frutidor.

Como apontado por Gauchet (1995, p. 218), o Colégio dos Conservadores era uma versão alargada do júri constitucional proposto por Sieyès em 1795. Nós já observamos que essa proposta, derrotada em 1795, continuou rondando os espíritos durante o Diretório, especialmente após o golpe do 18 Frutidor escancarar o problema do arbítrio necessário para salvar a República. Em Des circonstances, Staël havia retomado a figura do júri constitucional, na chave da função de guardião da Constituição, mas havia criticado a fraqueza de um corpo eleito que se reúne intermitentemente para julgar queixas contra os outros poderes, fazendo de seu poder conservador um órgão não eleito que integraria o Legislativo. Se, em 1798, Staël radicaliza Sieyès, em 1799, Sieyès radicaliza Staël. Como o poder conservador de Staël, seu Colégio dos Conservadores não seria mais eleito, como o era o júri constitucional. Porém, em vez de integrar o Legislativo, esse poder seria colocado acima dele, sendo simultaneamente seu eleitor e seu supervisor. Com efeito, as funções do Colégio dos Conservadores iriam muito além das eleitorais. Ele é apresentado como "um regulador entre as grandes autoridades independentes" (SIEYÈS, 1999, p. 524), um guardião do equilíbrio entre os poderes:

A garantia da ordem social reside na organização do estabelecimento público.

A garantia da liberdade civil, contra o estabelecimento público, reside na verdadeira divisão dos poderes; a garantia dos poderes, uns contra os outros (...), reside no Colégio dos Conservadores (SIEYĖS, 1999, p. 524).

Em seu manuscrito de 1799, Sieyès não se preocupa tanto em detalhar as funções específicas do Colégio dos Conservadores, contentando-se em escrever que "as outras atribuições do Colégio dos Conservadores estão indicadas em um discurso pronunciado 
na Convenção sobre a instituição de um júri constitucional" (SIEYĖS, 1999, p. 525). Em seu discurso de 18 Termidor do Ano III à Convenção, três funções haviam sido atribuídas ao júri constitucional: 1) revogar atos dos demais poderes contrários à Constituição, servindo como um tribunal de cassação; 2) formular propostas de aperfeiçoamento da Constituição, as quais deveriam ser apresentadas para a deliberação dos cidadãos a cada dez anos; 3) formar um júri de equidade natural para rever os casos em que a aplicação da lei positiva pelos juízes poderia resultar em injustiça (SIEYÈS apud TROPER, 2006, p. 524-539). Todas essas funções seriam atribuídas ao Colégio dos Conservadores. Entretanto, a ênfase de Sieyès agora não é na necessidade de um órgão que desempenhe funções constitucionais específicas. Por um lado, é a figuração da própria soberania nacional que está em jogo, já que ela não pode vir da pluralidade empírica de cidadãos. Por outro lado, o autor se preocupa em incorporar à República algo equivalente à antiga majestade do Rei, dessa vez a serviço da elevação simbólica do povo soberano, assim como um equivalente da antiga influência aristocrática. Sieyès (1999, p. 524) argumenta pela necessidade de um "poder moral" no topo do estabelecimento público, o qual, por sua influência sobre os costumes e espíritos, seria capaz de conter todos os movimentos particulares em uma esfera determinada e impedir os desvios das ambições desordenadas. Como Constant e Staël, o ex-abade vê a guerra cultural como determinante para terminar a Revolução Francesa, apostando que cabe à influência moral desse novo guardião da Constituição consolidar a preparação dos espíritos e dos costumes para a República. Assim, essa nova figura do poder conservador assume a função de censura, entendida como influência direcionada sobre as ideias e costumes do país - incorporando o papel de poder espiritual que Staël havia atribuído ao Institut national de France. Além disso, com a faculdade de cooptar os novos membros desse colegiado, alocando esses novos membros em um posto vitalício que proíbe o exercício de qualquer outro poder, o Colégio dos Conservadores colocaria em marcha um mecanismo melhorado do antigo ostracismo, absorvendo qualquer influência que, fora do órgão, poderia ser perigosa para a República (SIEYÈS, 1999, p. 525). 
Tanto no caso do Colégio dos Conservadores como no do Grande Eleitor, os poderes Legislativo e Executivo, respectivamente, recebem um tutor que os cria e vigia, sem se misturar diretamente a suas funções. Sobre o Grande Eleitor, ${ }^{60}$ Sieyès diz que

(...) governa-se, executa-se em seu nome, presta-se contas a ele, ele vigia, mas
ele não governa. (...). Ele imprime o movimento à máquina executiva e lhe
confere a unidade. (...) ele escolhe e destitui os governantes e os ministros etc.
sob a única influência de sua razão e da opinião pública bem constatada. (...).
Ele vigia o governo nas mãos dos cônsules e decide entre eles as discussões de
competência, mantendo a harmonia (SIEYĖS, 1999, p. 525).

Assim, o Colégio dos Conservadores e o Grande Eleitor constituem a versão sieyèsiana do problema de como incorporar o arbítrio ao sistema institucional após a prova do 18 Frutidor, na medida em que eles são autorizados a intervir sobre os poderes Legislativo e Executivo "sob a única influência de sua razão e da opinião pública bem constatada" - isto é, arbitrariamente. Todavia, não se trata aqui de um arbítrio pontual, como aquele por meio do qual Constant caracterizará seu poder neutro. Como assinala Gauchet, essas duas autoridades concebidas por Sieyès "não se contentam em exercer um controle ou marcar um limite: elas criam literalmente esses poderes que elas mantêm sob tutela sem participar deles" (GAUCHET, 1995, p. 221). É que, como procuramos mostrar, Sieyès mescla em um mesmo poder a figuração da soberania nacional, a guarda da Constituição, o equivalente moderno da antiga majestade monárquica e da antiga influência aristocrática e a função de poder espiritual. Em suma, ao incorporar o arbítrio ao sistema institucional, passa longe do projeto do ex-abade a ideia de neutralizar esse arbítrio. Pelo contrário, ele se torna o centro do novo sistema de poder, ao menos em sua dimensão simbólica.

Como já sugerido, o projeto constitucional de Sieyès não agradou inteiramente ao outro protagonista do 18 Brumário, Napoleão Bonaparte, que "transformou a Constituição senatorial de Sieyès em uma espécie de regime semi-presidencial no qual o primeiro-cônsul era investido de sua autoridade - imensa - pelo sufrágio universal"

${ }^{60}$ A ideia de um Grande Eleitor a supervisionar e eventualmente destituir os membros do Poder Executivo já havia sido mencionada por Roederer como uma das propostas em circulação para assegurar a unidade do Executivo, tanto em Du Gouvernement (1795) como em "Du parti qu'il est possible de tirer des évènements du 18 fructidor pour la chose publique" (1797) (ROEDERER, 1853-1859, VII, p. 43; ROEDERER, 1796-1797, V, p. 267). Há certa correspondência também entre o Grande Eleitor de Sieyès e o "grande conselho da nação" proposto por Bonaparte em sua carta a Talleyrand de 1797 citada acima (cf. p. 116-117 supra). 
(GUENIFFEY, 2011, p. 467). Apesar desse deslocamento do centro de poder, a Constituição do Ano VIII manteve o princípio das listas de elegibilidade e da eleição realizada por um órgão vitalício que exerce também controle constitucional - o Senado Conservador, nome adotado para o Colégio dos Conservadores de Sieyès. Se este não conseguiu fazer de seu guardião da Constituição o novo centro do poder, ele foi extremamente influente na redefinição teórica do governo representativo subjacente a seu projeto constitucional, a qual passou a ser defendida enfaticamente por intelectuais ligados aos idéologues ${ }^{61}$ e por figuras como Roederer, que até então não colocavam em questão o princípio da eleição. No que se refere aos idéologues, podemos acompanhar Pierre-Jean-Georges Cabanis, em sua defesa da Constituição do Ano VIII, afirmar:

(...) os corpos eleitorais relativos às diferentes ordens de funções devem ser instituídos não na base, mas na cúpula do estabelecimento: as escolhas devem partir, não de baixo, onde elas se fazem necessariamente mal, mas de cima, onde elas se farão necessariamente bem (CABANIS, An VIII, p. 25-26).

E, mais adiante:

No verdadeiro sistema representativo, tudo se faz, portanto, em nome do povo e para o povo; nada é feito diretamente por ele. (...) todo funcionário é escolhido entre os nomes inscritos nas listas populares, mas essas listas não convocam os eleitos para tal ou tal função em particular; o povo é soberano, mas todos os poderes de que sua soberania se compõe são delegados; (...) em suma, ele é livre, mas ele é calmo (CABANIS, An VIII, p. 36).

Quanto a Roederer, uma figura que participou ativamente do 18 Brumário, sua adesão à redefinição teórica do governo representativo empreendida por Sieyès ilustra bem o novo rumo seguido pelo liberalismo da ordem após a ascensão de Bonaparte. Embora, em seus projetos de reforma constitucional apresentados em 1795 e 1797, o princípio da eleição nunca tivesse sido colocado em questão, a partir do 18 Brumário, Roederer passa a argumentar que a França não teve governo representativo com os regimes eleitorais vigentes até então. Isso porque os representantes teriam representado apenas seções específicas do povo, por não terem sido nomeados por uma autoridade verdadeiramente nacional. Apenas com a Constituição do Ano VIII, que institui a eleição de cidadãos que gozam da confiança do povo pelo Senado Conservador, um órgão que representa a nação em sua unidade ideal, irredutível à dispersão empírica em seções, começaria a haver verdadeiramente governo representativo na França (ROEDERER, 1853-1859, VI, p. 392-395). Nesse governo verdadeiramente representativo, a ordem pública não seria mais ameaçada pelas más escolhas oriundas de eleições populares: “A

${ }^{61}$ Grupo de pensadores liderado por Antoine Destutt de Tracy. 
partir de agora, a multidão não elegerá mais para os cargos, mas somente para uma elegibilidade distante; ela estará segura de que, se fizer más escolhas, elas serão rejeitadas nas eleições depuradoras que sucedem à eleição popular" (ROEDERER, 1853-1859, VI, p. 394).

Em suma, se a figura sieyèsiana do guardião da Constituição se torna acessória no novo regime dominado pelo carisma e pelo poder pessoal de Bonaparte, a redefinição do governo representativo empreendida por Sieyès pode ser entendida como uma das respostas ao 18 Frutidor mais influentes intelectualmente no contexto brumariano. Essa resposta brumariana consiste basicamente na rejeição do princípio eleitoral, entendido como fonte de desordens e tumultos e como dispensável para o estabelecimento de uma representação nacional.

Curiosamente, uma das primeiras críticas contundentes a esse projeto brumariano vem de uma figura tratada nesta tese como um dos fundadores intelectuais do liberalismo da ordem: Necker. Em 1802, ele publica Dernières Vues de Politique et de Finance, offertes à la nation française par M. Necker, atacando a Constituição do Ano VIII como inviável de ser inscrita na longa duração. No máximo, observa o ex-ministro, o novo regime instituiu uma ditadura que restabeleceu a ordem na França. Porém, para merecer o título de Constituição republicana reivindicado por seus autores, de modo a poder se considerar como uma ordem política definitiva, tudo estaria faltando (NECKER, 1821, p. 80). Esse livro de Necker é considerado aqui como uma quinta resposta à crise aberta pelo golpe do 18 Frutidor, a qual não se contenta com o modo como o arbítrio é incorporado na Constituição brumariana e lança um projeto alternativo que considera o mesmo problema. Trata-se de outro caminho traçado pela mesma inspiração do liberalismo da ordem, mas em um rumo diferente do seguido por Roederer.

Em primeiro lugar, Necker não aceita tão facilmente quanto Roederer a supressão da eleição. "A primeira circunstância que nos choca ao examinar essa Constituição é que, em um governo intitulado republicano, nenhuma porção dos poderes políticos, nenhuma real, foi confiada à nação" (NECKER, 1821, p. 10). Diferentemente de Roederer, o liberalismo da ordem de Necker não se converte após Brumário em um autoritarismo liberal. Para ele, a participação popular não pode ser rechaçada em uma República (a rigor, nem mesmo em uma monarquia temperada). Em uma Constituição republicana, deve-se atribuir ao povo "todos os direitos políticos que ele pode exercer com ordem" (NECKER, 1821, p. 15). Para conciliar a participação popular com a ordem, a chave seria 
tirar partido "do espírito de propriedade, e das superioridades de educação que são o resultado necessário das diferenças de fortuna" (NECKER, 1821, p. 94). Assim, uma assembleia de proprietários formaria as listas de candidatos para apresentar à eleição pelo povo - inversamente ao sistema da Constituição do Ano VIII, em que o povo forma listas de elegibilidade para apresentar à eleição pelo Senado Conservador.

Assim, Necker critica o Senado Conservador em sua função de eleitor dos poderes públicos. Contudo, o que interessa mais a esta tese é sua crítica ao Senado Conservador como guardião da Constituição. Coerentemente com o liberalismo da ordem, tal como caracterizado nesta tese, sua principal crítica recai sobre a ausência de meios eficazes à disposição dessa autoridade teoricamente tão poderosa:

Ele está, em aparência, acima de todos os poderes. Ele deve vigiar os atos da legislatura e do governo. Ele tem por eminente prerrogativa o direito de anular os decretos, as proclamações, todas as ordens supremas. Mas, quando procuramos saber de que força esse Senado é investido para exercer uma autoridade tão violenta, uma missão tão perigosa, não percebemos nenhuma. Tudo está no papel, nada na realidade (NECKER, 1821, p. 34).

A abordagem de Necker é interessante por se concentrar não nos atributos do guardião da Constituição (em certe medida, a ênfase de Sieyès e Staël), mas em sua força real, medida pelos meios efetivos à sua disposição. Para o autor, o poder político real se baseia ou na força militar, ou na opinião pública, e o Senado Conservador não se sustenta em nenhuma dessas duas bases (NECKER, 1821, p. 35). Assim, mesmo com todas as decisões discricionárias que a Constituição lhe atribui, o único modo de efetivá-las é tornando-se uma marionete do Poder Executivo, o órgão que dispõe de toda a força nesse regime veladamente ditatorial que é o Consulado.

Desse modo, na Constituição republicana proposta por Necker (é a primeira vez que ele admite a viabilidade de uma República igualitária, una e indivisível em um grande país, reconhecendo que o federalismo americano e a monarquia temperada britânica não são mais alternativas para a França nas condições atuais), o arbítrio não é incorporado em um órgão como o Senado Conservador, devido à fraqueza de fato de um poder assim afastado da dinâmica política real. Não obstante, o autor concorda com a literatura que vem sendo examinada neste capítulo sobre a necessidade de alocar alguma dose de arbítrio ao sistema institucional para dar uma resposta a crises como o 18 Frutidor. Por um lado, o arbítrio aparece em sua discussão sobre a responsabilidade do governo. Tendo alocado o Poder Legislativo em dois conselhos (o "Grande Conselho Nacional" e o "Pequeno Conselho Nacional") e o Poder Executivo em um Senado Executivo de sete 
membros sob a presidência anual de um Cônsul, Necker prega que esse Cônsul seja responsável perante o Legislativo, podendo ser acusado pelo Grande Conselho Nacional e destituído pelo Pequeno Conselho Nacional. Embora, em geral, esse tipo de condenação devesse ser sujeito "a formas jurídicas e precisas, pode-se razoavelmente transgredir essa regra para um caso único: tal seria a acusação dirigida contra o chefe do Estado" (NECKER, 1821, p. 163). Em outras palavras, dada a natureza política da responsabilidade do Poder Executivo, ela deve ser operada em bases discricionárias. ${ }^{62} \mathrm{E}$ o responsável por essa decisão discricionária não pode ser um poder que paira no ar como o Senado Conservador, mas um poder efetivo em constante comunicação com a opinião pública, como o é o Legislativo.

Por outro lado, Necker se depara com a questão do que fazer com a figura de Bonaparte. Não se tratava de um problema menor, pois o autor parece ter consciência da transmutação do regime de legitimidade operada após o 18 Brumário. Após dez anos de busca de uma legitimidade impessoal, a França havia saído das crises revolucionárias aderindo a uma legitimidade carismática ou plebiscitária, na qual ocorre "a materialização do coletivo em um homem" (GAUCHET, 1995, p. 214). ${ }^{63}$ Necker sabe que seu plano constitucional só pode prosperar com o assentimento de Bonaparte, não apenas porque este detém o poder efetivo, mas também porque ele concentra a legitimidade do regime em vigor. Para retornar a uma legitimidade impessoal, é preciso fazer uma transição na qual a legitimidade carismática vigente colabore para a consolidação das novas instituições. Assim, Necker propõe que Bonaparte seja, no início, o Poder Executivo único da República projetada, pelo tempo que ele julgar conveniente. Uma vez firmada essa nova República, Napoleão conservaria ainda "a autoridade necessária para inspecionar e sustentar o governo novo em seu funcionamento" (NECKER, 1821, p. 258). "Eu gostaria que ele permanecesse o guardião da nova Constituição, de uma Constituição que ele legaria um dia, em sua inteireza, às gerações vindouras” (NECKER, 1821, p. 258). Portanto, o guardião da Constituição concebido por Necker não é mais do que um mecanismo de transição entre a legitimidade carismática e a impessoal, destinado a desaparecer uma vez completada a transição.

${ }^{62}$ Constant se inspirará nesse aspecto do pensamento de Necker em sua discussão sobre a responsabilidade dos ministros nos primeiros anos da Restauração, como veremos no Capítulo 4 desta tese.

${ }^{63}$ Ver também: GUENIFFEY, 2008, p. 265-275. 


\subsection{Uma autoridade discricionária}

Os Fragments d'un ouvrage abandonné sur la possibilité d'une constitution républicaine dans un grand pays, de Constant, são considerados aqui como a primeira resposta acabada do autor ao teste colocado pelo golpe do 18 Frutidor. Nessa obra, cujas circunstâncias crescentemente autoritárias impediram a publicação, o jovem autor francosuíço busca superar as contradições de seu discurso do 30 Frutidor por meio de uma Constituição que, incorporando pacificamente o arbítrio, impedisse a necessidade de novos golpes de Estado. Nesse empreendimento, ele considera as respostas de Roederer, Staël, Sieyès e Necker, ${ }^{64}$ que já haviam caminhado na direção da incorporação controlada do arbítrio às instituições. Constant assimila alguns elementos dessas respostas, mas as critica implícita ou explicitamente, como insuficientes para a resolução do problema posto pelo 18 Frutidor.

Antes de abordar diretamente os Fragments, cabe repassar brevemente a trajetória intelectual e política de Constant entre o 18 Frutidor e a escrita da obra. Em 27 de fevereiro de 1798 (9 Ventôse do Ano VI), ele faz um novo discurso ao Cercle constitutionnel, voltado dessa vez primordialmente contra os neojacobinos, tornados os principais adversários do Diretório após o expurgo dos monarquistas em 18 Frutidor. Nesse discurso, o jovem orador retoma a necessidade de manter o poder centralizado nas mãos dos republicanos, insinuando que estes estão dispostos a realizar um novo 18 Frutidor se for necessário. Porém, mais uma vez, o arbítrio é implacavelmente condenado, e o autor propõe sua erradicação absoluta por meio de três remédios: 1) a previdência dos legisladores, fazendo leis severas, mas precisas; rigorosas, mas fixas; 2) a observância das formas, e 3) a responsabilidade dos agentes. Na defesa do primeiro remédio, Constant

${ }^{64}$ Não podemos afirmar se ele leva em consideração a resposta de Bonaparte em sua carta de 1797 a Talleyrand, pois não sabemos se ele teve acesso ao conteúdo da carta. É possível que ele tenha tido esse acesso, pois ele pertencia ao círculo de Talleyrand e Bonaparte: em outra carta, o ministro das Relações Exteriores chega a propor o nome de Constant para auxiliar o general na redação de uma Constituição para o norte da Itália (GUENIFFEY, 2008, p. 160). De todo modo, Constant leva em consideração, nos Fragments, a tendência de Bonaparte a privilegiar o Poder Executivo em relação ao Legislativo, formulando uma crítica a essa apoteose do Executivo. 
adota a retórica de um republicano clássico, chegando a elogiar a severidade das leis em Esparta: "Não é o jugo da lei que os republicanos temem. Eles o veneravam em Esparta. Eles detestam a ilegalidade. O que os republicanos desejam não é a independência; eles a encontrariam em Constantinopla. Eles reivindicam a segurança" (CONSTANT, 1998a, p. 595).

Quando o autor publica Des suites de la contre-révolution de 1660 en Angleterre, em junho de 1799, uma grande evolução parece ter se operado em seu pensamento - em parte, devido ao diálogo com Staël a respeito de Des circonstances. Constant permanece um republicano resoluto: o objetivo principal da obra é alertar para o perigo de uma restauração monárquica, apoiando-se para isso no exemplo da restauração monárquica ocorrida na Inglaterra em 1660 - seguida, segundo o autor, de catástrofes sangrentas e do descumprimento da promessa de paz que selou a ascensão de Carlos II ao trono, o que provaria que as palavras dos reis nunca são confiáveis. O que nos interessa, entretanto, é o fim do livro, quando Constant critica pela primeira vez publicamente o poder arbitrário exercido pelo Diretório desde o 18 Frutidor, atribuindo essa necessidade do arbítrio a uma lacuna na Constituição de 1795. Ele se propõe a apresentar em escritos futuros a maneira de preencher essa lacuna sem alterar as bases da Constituição. Mais especificamente, ele anuncia que o assunto será tratado nos comentários acrescidos à tradução que ele estava realizando da obra de William Godwin, Enquiry Concerning Political Justice, de 1793, a qual não foi publicada em vida (CONSTANT, 1998a, 676). No entanto, é evidente que, em meados de 1799, Constant já estava elaborando os manuscritos dos Fragments e já fazia especulações sobre o poder neutro, tendo como principal base Des circonstances de Staël.

O golpe do 18 Brumário coloca a dupla Constant e Staël em uma situação ambígua e delicada. Por um lado, ambos tinham conexões íntimas com Sieyès e o admiravam profundamente, além de apostarem na lealdade de Bonaparte à República. Além disso, os dois amantes vinham refletindo desde o 18 Frutidor sobre a reforma das instituições diretoriais, e o 18 Brumário abria enfim a possibilidade de realizar essa reforma, o que seria impossível pelas vias ordinárias e constitucionais. Por outro lado, Constant e Staël logo percebem que a ruptura promovida por Bonaparte, Sieyès e seus comparsas estava indo muito além do preenchimento da "lacuna" que eles viam na Constituição de 1795. Era o próprio sentido republicano e liberal da Constituição do Ano III que passava a ser desmontado pelos brumarianos, da supressão da eleição popular ao poder pessoal 
tendencialmente ilimitado de Bonaparte. É assim que se aprofunda, após Brumário, a clivagem tratada no Capítulo 1 entre Constant e o liberalismo da ordem, com Staël constituindo, durante o Diretório, uma espécie de mediação. Com a redefinição teórica do governo representativo empreendida na Constituição do Ano VIII, o liberalismo da ordem de Sieyès e Roederer se torna verdadeiramente autoritário, e Constant e Staël passam a formar uma oposição liberal-republicana que logo lhes custa a marginalização política e o exílio.

A transformação de Constant, de aliado dos brumarianos a inimigo do regime consular, não durou mais do que dois anos. No final de 1799, o Senado Conservador o nomeava (por influência de Sieyès) para o Tribunato, o órgão encarregado de discutir os projetos de lei sem poder votar sua aprovação ou rejeição. Em janeiro de 1802, o jovem orador era expulso de sua primeira função pública, já com a pecha de opositor radical ao regime. Seus discursos no Tribunato constituem, com efeito, um momento importante da formação de uma oposição liberal-republicana a Bonaparte, com consequências significativas para a gênese do liberalismo como família política, ao menos na França ${ }^{65}$

Nesses discursos, Constant se consagra como um dos principais opositores à tendência autoritária do Consulado, manifesta desde os primeiros dias do regime. ${ }^{66} \mathrm{Nessa}$ oposição ao autoritarismo bonapartista, o jovem orador dota de grande eloquência retórica sua crítica do arbítrio formulada durante o Diretório, dirigindo essa crítica contra as leis de urgência (CONSTANT, 2005a, p. 78-79), os tribunais extraordinários (CONSTANT, 2005a, p. 215-244) e as tentativas de flexibilizar o seguimento da lei, particularmente em matéria de repressão criminal e política, com o pretexto de priorizar o "espírito" em relação à letra da Constituição (CONSTANT, 2005a, p. 237).

Expulso do Tribunato no início de 1802, Constant volta a se dedicar sistematicamente às reflexões político-constitucionais que o rondavam ao menos desde 1799, as quais resultam na versão conhecida dos Fragments d'un ouvrage abandonné sur

65 Ver JAINCHILL, 2008, Cap. 6 (“Liberal Republicanism and Dissent against Bonaparte”). Jainchill argumenta que os valores liberais difundidos por autores como Constant adquirem consistência própria na oposição a Bonaparte, não em reação ao Terror, como relata a interpretação convencional. Ao mesmo tempo, esse liberalismo nascente no Consulado incorpora, segundo Jainchill, temas do republicanismo clássico dominante no Diretório, opondo-se ao "autoritarismo liberal" dos brumarianos.

${ }^{66}$ É o primeiro grande momento que consagra o discurso político de Constant como um “liberalismo de oposição" (MANENT, 2012, Cap. 8). 
la possibilité d'une constitution républicaine dans un grand pays. ${ }^{67}$ Como nota Gauchet (1995, p. 240), esse livro se inscreve na problemática da reforma da Constituição de 1795 após o golpe do 18 Frutidor, praticamente ignorando o fato de que o 18 Brumário já havia lançado a França em outra lógica constitucional. Com efeito, o trecho mencionado de Des suites de la contre-révolution de 1660 en Angleterre indica que boa parte do argumento dos Fragments é formulado antes mesmo do 18 Brumário. Todavia, parte significativa do livro acaba se transformando em uma crítica severa do regime consular e dos pressupostos intelectuais que o fundamentam. Se a grande lição que Roederer, Staël, os brumarianos e Necker extraíram do 18 Frutidor é a necessidade de incorporar o arbítrio ao sistema institucional para impedir sua manifestação como golpe de Estado, Constant conclui que o arbítrio deve ser incorporado de outro modo, menos propício a produzir regimes autoritários como o que emergiu do 18 Brumário.

A pergunta que o livro tenta responder é qual é o melhor modelo de Constituição republicana para um grande país como a França, tendo como premissas (justificadas no início da obra) a rejeição de qualquer função hereditária e de um Executivo unitário, a separação entre os poderes Legislativo e Executivo e a eleição temporária como único princípio de constituição dos poderes (CONSTANT, 1991, p. 361-362). A defesa da eleição popular para o Legislativo constitui a crítica mais profunda de Constant à obra dos brumarianos. Ele retoma a crítica formulada por Necker, em 1802, à supressão da eleição popular pela Constituição do Ano VIII, argumentando que apenas a eleição popular estabelece "relações frequentes entre as diversas classes da sociedade" (CONSTANT, 1991, p. 297), obrigando as classes superiores e os poderosos a “dissimular sua arrogância" (CONSTANT, 1991, p. 297) e levar em consideração os interesses das classes inferiores. ${ }^{68}$ Segundo Constant (1991, p. 291), todas as experiências antigas e modernas, assim como os grandes escritores políticos de todas as épocas, depõem a favor da eleição popular, mas esta se tornou desacreditada após as infelicidades da Revolução Francesa. Essas crises revolucionárias (especialmente a necessidade de anular os resultados de eleições durante o Diretório) levaram os brumarianos a suprimir a eleição. No entanto, para o autor franco-suíço, o problema das eleições da Revolução Francesa não estava no princípio eletivo, mas na eleição em dois graus, na ausência de verdadeira liberdade eleitoral e na falta de limites ao Poder Legislativo. Como remédio a

\footnotetext{
${ }^{67}$ Sobre a gênese do texto e as dificuldades relativas a sua datação precisa, ver GRANGE, 1991.

${ }^{68}$ Ver NECKER, 1821, p. 13-14, onde o ex-ministro de Luís XVI emprega o mesmo argumento.
} 
esses males, não se deveria suprimir a eleição, mas, pelo contrário, torná-la mais popular, realizando-a de modo direto e em assembleias mais numerosas. Levando em consideração a proposta de Necker já exposta, pela qual uma assembleia de cem proprietários formaria em cada circunscrição uma lista de cinco candidatos para apresentar ao povo, Constant tenta moderar a influência dos proprietários, obrigando-os a formar essa lista de cinco candidatos a partir de uma lista de cinquenta candidatos formada pelo povo, para que este não exerça apenas a escolha definitiva, mas também a iniciativa do processo. Porém, afirma o autor, "se eu transijo sobre a eleição simples, imediata e direta, é apenas para me adaptar à opinião dominante" (CONSTANT, 1991, p. 318). Contra os que veem na eleição simples e direta uma forma de tumulto popular, Constant argumenta que essa agitação, mesmo quando parece extravasar certos limites, é necessária para formar o espírito público e consolidar o sentimento da liberdade republicana: "para que o sentimento da liberdade penetre na alma do povo, é preciso, talvez, que a liberdade se revista às vezes de formas a seu alcance, formas populares, tempestuosas e barulhentas" (CONSTANT, 1991, p. 319).

Embora Constant poupe a figura de Sieyès, ele não economiza críticas aos dois defensores da Constituição do Ano VIII abordados na Seção 2.2, Cabanis e Roederer. Aos olhos do escritor franco-suíço, a redefinição do governo representativo proposta por aqueles autores, visando a excluir o povo dividido em seções e reservar as nomeações políticas a um órgão verdadeiramente nacional que encarnaria o interesse geral, é verdadeiramente absurda:

Esses raciocínios repousam sobre uma ideia muito exagerada do interesse
geral, do objetivo geral, da legislação geral, de todas as coisas às quais se aplica
esse epíteto. O que é o interesse geral, senão a transação operada entre todos
os interesses particulares? O que é a representação geral, senão a representação
de todos os interesses parciais que devem transigir sobre os objetos que lhes
são comuns? O interesse geral é, sem dúvida, distinto dos interesses
particulares; mas ele não lhes é contrário (CONSTANT, 1991, p. 309).

Quanto ao argumento de que as escolhas feitas na base do edifício social são necessariamente ruins, devendo ser realizadas pela autoridade esclarecida situada no topo, Constant recorre às autoridades intelectuais de Maquiavel e Montesquieu para ressaltar "o admirável instinto do povo para escolher os órgãos de sua vontade e os defensores de seus interesses" (CONSTANT, 1991, p. 292). Em suma, o autor franco-suíço rejeita radicalmente a resposta que se torna mais influente, após o 18 Brumário, à questão de como lidar com os desafios colocados pelo 18 Frutidor. Se as eleições estavam sendo percebidas como uma ameaça à República, os brumarianos respondem a esse desafio 
substituindo a eleição popular por uma encarnação do interesse geral em uma autoridade situada no topo do edifício social, a qual seria mais apta a realizar as nomeações políticas. Denunciando nesse expediente uma metafísica enviesada que esvazia a noção de interesse geral ao romper sua conexão com os interesses parciais que compõem o corpo político, Constant se propõe a retornar à legitimidade política pré-brumariana e responder aos desafios do 18 Frutidor no quadro de uma Constituição em que todas as funções se originam direta ou indiretamente da eleição popular.

Além da eleição popular, o outro princípio básico da organização constitucional proposta por Constant é a divisão dos poderes, concebida "exclusivamente sob o ângulo dos abusos que eles são suscetíveis de cometer e das garantias que é possível lhes opor" (GAUCHET, 1995, p. 243; ênfases do autor). Nesse âmbito, o autor franco-suíço estabelece um diálogo crítico com o liberalismo da ordem formulado por Necker, o qual se manifesta nas propostas constitucionais de Roederer, e por vezes nas de Staël. Contra Necker, ${ }^{69}$ Constant retoma a compreensão predominante entre os revolucionários franceses de que "o Poder Legislativo é, evidentemente, o primeiro de todos em posição e dignidade" (CONSTANT, 1991, p. 151), já que cabe a ele exprimir a vontade nacional. Porém, o autor incorpora as críticas do liberalismo da ordem à ausência de limites colocados ao Poder Legislativo pelas constituições revolucionárias, vendo nessa falta de limites uma das causas centrais de golpes como o 18 Frutidor. Por isso, ele concorda com Necker, Roederer e Staël que "é preciso investir o Poder Executivo de diversas prerrogativas e mesmo, em muitos aspectos, de certa independência" (CONSTANT, 1991, p. 152). Como os autores do liberalismo da ordem, Constant considera a fraqueza do Executivo como um mal que o leva a transgredir a Constituição para se proteger de um Legislativo todo-poderoso. Embora o Legislativo seja o primeiro poder em dignidade, ele é propício a se desviar, usurpar os demais poderes e invadir as liberdades dos cidadãos, de modo que "é preciso haver, com toda a necessidade, um meio constitucional de frear os desvios das assembleias. Se esse meio não se encontrar na Constituição, os eventos o alocarão fora da Constituição, e a Constituição será rompida" (CONSTANT, 1991, p.

${ }^{69}$ E também contra a concepção presente na carta enviada por Bonaparte a Talleyrand em 1797, a qual fazia do Poder Executivo o centro do poder e o representante verdadeiro da nação. Como indicado na nota 64, não se sabe se Constant teve acesso a essa carta, mas sua afirmação de que o Poder Legislativo é o primeiro em posição e dignidade pode ser lida como uma crítica à elevação desproporcional do Poder Executivo promovida por Bonaparte após o 18 Brumário. 
279). Em um primeiro momento, o autor preconiza as garantias contra os excessos legislativos inspiradas na Constituição inglesa: "a divisão em duas Câmaras, o veto do Poder Executivo e a possibilidade de dissolução da representação nacional" (CONSTANT, 1991, p. 275).

Não obstante, o problema de Constant é mais complexo do que o do liberalismo da ordem, pois ele teme também as usurpações do Poder Executivo, as quais Necker e Roederer viam como impossíveis nas situações em que o Executivo está protegido contra o Legislativo. Vimos que a resposta de Roederer ao 18 Frutidor podia se limitar ao fortalecimento do Executivo, porque ele não acreditava que um Executivo seguro de si mesmo pudesse ser usurpador. Para Constant, ao contrário, “é necessário, assim, preparar os meios de repressão contra o Poder Executivo, como nós os preparamos contra o Poder Legislativo" (CONSTANT, 1991, p. 324). É sua principal divergência (implícita) com a resposta ao 18 Frutidor formulada por Roederer em 1797. As principais garantias contra os abusos do Executivo elencadas por Constant são a independência do Poder Judiciário (um poder que o autor considera nulo politicamente, seguindo Montesquieu, mas divergindo do autor de $O$ espírito das leis ao pregar a constituição do Judiciário como corpo), a responsabilidade, e a separação estrita entre exército e polícia, com a proibição de o governo mobilizar a força militar dentro do território nacional.

Contudo, a maior originalidade dos Fragments consiste no Livro VIII (“D'un pouvoir neutre ou préservateur, nécessaire dans toutes les constitutions"), em que Constant retoma todas essas garantias contra os possíveis abusos dos poderes Legislativo e Executivo, concluindo que elas "não garantem suficientemente nem os poderes constituídos um contra o outro, quando eles se dividem, nem os cidadãos contra esses poderes, se eles se unem" (CONSTANT, 1991, p. 371). Daí a necessidade de "um terceiro poder que seja neutro entre o Poder Legislativo e o Poder Executivo" (CONSTANT, 1991, p. 373). Em um primeiro aspecto, esse poder neutro é o guardião da Constituição concebido por Constant, sob inspiração direta do júri constitucional proposto por Sieyès em 1795. Assim como Sieyès havia afirmado que "uma Constituição é um corpo de leis obrigatórias, ou não é nada; se é um corpo de leis, pergunta-se onde estará o guardião, onde estará a magistratura desse código" (SIEYÈS apud TROPER, 2006, p. 525), Constant se pergunta, a respeito das liberdades prometidas pela Constituição: "Se não existissem nem juízes nem tribunais, de que serviria o melhor código de leis criminais?" (CONSTANT, 1991, p. 371). Não bastam um Poder Legislativo que expressa a vontade 
nacional e um Executivo que a executa: precisa haver um terceiro poder que fiscaliza a boa relação entre eles e o respeito à liberdade dos cidadãos. "O poder preservador é, por assim dizer, o Poder Judiciário dos outros poderes” (CONSTANT, 1991, p. 390).

Se Constant tem o Sieyès de 1795 como fonte de inspiração, seu problema é como impedir a necessidade de golpes como o 18 Frutidor, tendo se convencido de que alguma dose de arbítrio é necessária nos momentos de crise. Por isso, as atribuições de seu poder neutro diferem das do júri constitucional de Sieyès. Ao passo que este tinha como atribuição principal revogar os atos dos poderes Legislativo e Executivo contrários à Constituição, o poder neutro de Constant é menos um tribunal constitucional do que um ator autorizado a resolver crises políticas rapidamente, antes que elas coloquem em risco a Constituição. ${ }^{70}$ Suas faculdades principais são a de "dissolver as assembleias legislativas e a de destituir os depositários do Poder Executivo" (CONSTANT, 1991, p. 387). Seu quadro de referência é menos um tribunal do que a instituição da ballia, conselho extraordinário que, em Florença, tinha o poder de cassar todos os magistrados (CONSTANT, 1991, p. 396). O objetivo do autor é realizar de modo pacífico e institucional o que, em Florença e outras repúblicas (são citados também exemplos da destituição violenta dos governantes em Esparta, Creta, Atenas e Roma), era exercido de modo extraordinário e violento.

Nesse sentido, o direito que define a essência do poder neutro é o de "destituir o Poder Executivo, sem abrir processo, sem pronunciar um julgamento contra ele" (CONSTANT, 1991, p. 387). Constant caracteriza esse poder como uma "autoridade discricionária” (CONSTANT, 1991, p. 381). Nessa dimensão, ele é completamente diferente do Judiciário, compreendido como "uma autoridade sujeita a formas" (CONSTANT, 1991, p. 381). Embora o poder neutro seja o Judiciário dos poderes, o autor argumenta que os poderes Executivo e Legislativo conseguiriam lhe opor suas forças se ele operasse segundo a mesma lógica e o mesmo ritmo do Judiciário em relação aos indivíduos. Portanto, "é necessário que sua rapidez compense o que lhe falta em força” (CONSTANT, 1991, p. 391). Com o poder neutro, Constant realiza assim a incorporação do arbítrio ao sistema institucional. Após admitir a necessidade do golpe do 18 Frutidor, sua simples condenação das medidas extraordinárias é revista, e o autor

${ }^{70}$ Sobre as continuidades e rupturas do poder neutro de Constant em relação ao júri constitucional de Sieyès, ver: JAUME, 2002, p. 189-192. 
argumenta agora que as medidas de exceção podem ser admitidas quando se abatem sobre poderes, não sobre pessoas: “A salvação do Estado pode exigir medidas extraordinárias, mas essas medidas só devem se aplicar aos poderes, não aos homens. Um poder é a criação da sociedade. Ele pode ser suspendido, modificado, dissolvido por ela. Um homem é anterior à sociedade " (CONSTANT, 1991, p. 400). Assim, o poder neutro teria a faculdade de dissolver arbitrariamente uma assembleia legislativa ou destituir discricionariamente os depositários do Poder Executivo, mas jamais a de punir os representantes ou governantes destituídos, pois isso seria inconcebível sem um julgamento segundo as formas legais.

Cabe observar que Constant tem o cuidado de caracterizar o poder neutro como uma autoridade "discricionária" (discrétionnaire), evitando o termo "arbitrária" (arbitraire), inevitavelmente ligado à ideia de tirania, de uma vontade absoluta que se coloca acima das leis e da Constituição. Todavia, é preciso ter em mente que, nos escritos do autor, as ideias de "discricionário" e "arbitrário" se aproximam consideravelmente, sendo os dois termos por vezes intercambiáveis. Isso pode ser ilustrado por meio de uma passagem de Des suites de la contre-révolution de 1660 en Angleterre já referida na Introdução desta tese (cf. p. 27, nota 13 supra), na qual Constant cita um trecho de History of England (1754-1762) de David Hume, em que o filósofo e historiador escocês se refere a uma lei que permitia ao Rei da Inglaterra escolher arbitrariamente a punição a determinados tipos de crime. No trecho, que Constant reproduz em inglês em sua obra, Hume afirma que as cortes penais, ao delegar ao Rei a escolha da punição, "determinavam que a punição seria arbitrária [arbitrary]" (HUME apud CONSTANT, 1998a, p. 660; itálico nosso). Na paráfrase quase literal feita em francês, contudo, o autor escreve: "proibir uma ação, sem anexar à transgressão dessa lei uma pena legal, era conferir ao Rei um poder discricionário [discrétionnaire] sobre o criminoso" (CONSTANT, 1998a, p. 660; itálico nosso). Em outras palavras, Constant via a palavra "discricionário" como sinônimo de "arbitrário", pois, nos dois casos, há a ideia de uma decisão marcada pela "ausência de regras, de limites, de definições, em suma, a ausência de tudo o que é preciso" (CONSTANT, 1998a, p. 496) - sendo esta a definição de arbítrio fornecida em Des réactions politiques, de 1797 (cf. p. 21 supra). Uma hipótese para o autor preferir a palavra "discricionário" para a caracterização do poder neutro é que esse termo remete à ausência de precisão característica do arbítrio, sem implicar tão diretamente a ideia de tirania ou poder absoluto. Por trás da utilização desse termo, há uma reavaliação, da parte 
de Constant, sobre a necessidade e a legitimidade de ações políticas que se produzem fora do marco das formas claras estabelecidas pela lei. Nós atribuímos essa reavaliação à prova fornecida pelo 18 Frutidor. Não obstante, como o termo arbitraire é carregado de um valor essencialmente pejorativo, o autor prefere se referir a essas ações políticas efetuadas sem a determinação de formas legais claras (compreendidas na definição de arbítrio proposta em Des réactions politiques) pelo termo discrétionnaire. Podemos interpretar essa operação linguística à luz das estratégias retóricas que, segundo Skinner, os ideólogos inovadores são obrigados a empregar para legitimar cursos de ação até então vistos como reprováveis. ${ }^{71}$ Skinner utiliza o exemplo da palavra "ambição" (ambition), de sentido predominantemente depreciativo até o início da era moderna, sendo esse sentido paulatinamente neutralizado pelos primeiros defensores do espírito comercial capitalista (SKINNER, 2002a, p. 152). Do mesmo modo, ao tratar o poder neutro como uma "autoridade discricionária", Constant procura, em nossa interpretação, neutralizar o sentido de uma ideia (a da decisão não determinada pelas normas legais) até então tratada predominantemente, inclusive por ele próprio, como fonte de tirania. Porém, era difícil operar essa neutralização de sentido com a palavra arbitraire, o que leva o autor a empregar discrétionnaire.

De todo modo, não se tratava apenas de neutralizar o sentido da palavra "arbítrio", de um ponto de vista linguístico e retórico. Tratava-se de garantir, pelo próprio desenho institucional, que esse arbítrio incorporado pelo poder neutro não degenerasse em tirania. Como vimos, a aplicação do arbítrio a poderes em vez de pessoas é uma das soluções encontradas por Constant para o problema de como incorporar esse arbítrio ao sistema político, impedindo sua deriva tirânica. Essa solução não é a única. Para além da interdição de que o arbítrio se aplique a indivíduos, o autor se preocupa com a questão de como criar um poder verdadeiramente neutro, que não utilize sua prerrogativa de ação discricionária para expandir os poderes do Legislativo ou do Executivo. No tratamento dessa questão, Constant se afasta das respostas ao 18 Frutidor trazidas por Staël e pelos brumarianos, os quais já haviam incorporado um poder com faculdade de ação discricionária para impedir a necessidade de novos golpes, mas, na avaliação do autor, não tomaram o cuidado de preservar a neutralidade desse poder. Segundo os Fragments,

${ }^{71}$ Ver o ensaio "Moral principles and social change", em SKINNER, 2002a, p. 145-157 (Cap. 8). 
o móbil dos poderes é seu interesse. ${ }^{72} \mathrm{O}$ que cria um poder neutro entre o Legislativo e o Executivo é, portanto, um interesse simultâneo pela liberdade do povo (logo, pela dignidade do Poder Legislativo que o representa) e pela estabilidade do governo, logo do Poder Executivo. Em suma, os membros do poder neutro precisariam reunir os interesses dos governados e dos governantes, em essência antagônicos. Constant vê a possibilidade dessa reunião nas duas características distintivas do Senado Conservador da Constituição do Ano VIII: a vitaliciedade e a inelegibilidade para qualquer outra função. A primeira característica faz do Senado um corpo à parte com interesse distinto do da massa dos cidadãos, interessado primordialmente na conservação da Constituição que o destaca dessa forma. A segunda característica, por sua vez, faz os membros do Senado não se confundirem com a classe dos governantes nem almejarem chegar a ela, compartilhando com os governados o interesse pela liberdade do povo. Assim, a Constituição do Ano VIII teria criado um poder verdadeiramente neutro para vigiar os demais poderes, se não tivesse acrescentado a esse poder funções que desnaturam sua neutralidade principalmente a eleição do Poder Legislativo, a qual permite aos membros do Senado Conservador nomear seus aliados para o Legislativo e controlá-lo indiretamente.

"Outra atribuição que desnaturaria o poder preservador seria o direito de participar, como segunda Câmara, da confecção das leis" (CONSTANT, 1991, p. 385). Aqui, é o poder conservador proposto por Staël em Des circonstances que é criticado. Como segunda câmara, esse poder deixaria de ser neutro, pois "tornado parte do Poder Legislativo, ele ganharia com as invasões e extensões da autoridade legislativa" (CONSTANT, 1991, p. 386). Além disso, uma câmara inamovível, mas sem o prestígio antigo da hereditariedade, seria fraca demais para resistir à vontade de uma assembleia eleita (CONSTANT, 1991, p. 386). No fundo, Constant está criticando o modelo da ditadura reivindicado por Staël como forma de incorporar e domesticar o arbítrio no interior do sistema institucional. Mesmo fiéis aos ideais republicanos, os "ditadores" alocados no corpo conservador staëliano seriam levados por sua posição a perseguir interesses próprios, os quais consistiriam basicamente no aumento indevido do poder do Legislativo do qual eles fariam parte. Sua aparente força revestiria na verdade uma fraqueza, pois, não tendo sido eleitos, esses “ditadores" não encontrariam respeito quando tentassem tutelar a confecção da lei. Para Constant, não se tratava de instaurar uma

${ }^{72}$ É o que Barberis chama de "princípio do interesse" (BARBERIS, 1996, p. 135), um dos eixos norteadores do constitucionalismo das revoluções americana e francesa. 
ditadura provisória dos amigos da República, mas de encontrar uma posição estrutural em que o arbítrio pudesse ser exercido de modo controlado. Seria essa posição estrutural (determinada basicamente pela vitaliciedade e pela não elegibilidade a outros cargos), não a fidelidade ideológica à República, que criaria um interesse neutro capaz de realizar intervenções discricionárias no jogo político sem submeter todo o sistema a uma vontade arbitrária. $^{73}$

Seguindo essa linha de raciocínio, Constant retira das atribuições de seu poder neutro a função de censura ou de autoridade espiritual que Staël havia atribuído ao Institut national de France, e Sieyès, ao Colégio dos Conservadores. O poder preservador não é "um poder conservador que se exerceria a favor de uma massa de opiniões qualquer" (CONSTANT, 1991, p. 417), afirma o autor, retirando a centralidade da guerra cultural pelo enraizamento das ideias e costumes republicanos que ele havia pregado em seguida ao golpe do 18 Frutidor. Tendo já avançado na direção de uma filosofia liberal mais amadurecida, Constant critica os governos que se veem encarregados de consagrar ou destruir determinado conjunto de opiniões entre os governados, ironizando os que tentaram fazer do amor à República uma nova espécie de fanatismo oficial (CONSTANT, 1991, p. 416-417). Afastando seu poder neutro da guerra cultural em que autores como Staël e Sieyès o haviam inserido, o autor retira certo peso de sua função, restrita agora à conservação "das garantias da liberdade, da independência das faculdades individuais e, por esse motivo, da segurança física dos indivíduos" (CONSTANT, 1991, p. 416), não mais da República entendida como um conjunto exigente de costumes e convicções. $\mathrm{O}$ poder preservador é comparado a um arquiteto que contribui para a felicidade dos

${ }^{73}$ Ainda sobre a posição estrutural do poder neutro, cabe observar que Constant diverge de Staël e Sieyès ao tornar o poder preservador totalmente eletivo (um membro seria eleito por cada departamento, havendo nova eleição no departamento em questão quando um membro do poder neutro falecesse), não podendo ele próprio recrutar seus membros, nem os poderes Executivo e Legislativo interferir nessa escolha. $\mathrm{O}$ autor se preocupa em não tornar seu poder neutro uma espécie de oligarquia (a crítica principal dirigida ao poder conservador de Staël e ao Colégio dos Conservadores de Sieyès), assim como em garantir a independência do poder preservador perante os demais poderes (CONSTANT, 1991, p. 437). O poder neutro sofreria, assim, alguma influência do "espírito popular" (CONSTANT, 1991, p. 437), mas essa influência seria temperada pela vitaliciedade, pela gradação de funções, pela entrada de membros do Poder Executivo após o término de seu mandato, pela condição de idade (mínimo de quarenta anos) e pelas vantagens pecuniárias (na forma de propriedades territoriais) atreladas ao cargo (CONSTANT, 1991, p. 438-439). 
habitantes de uma casa ao garantir sua segurança, mas sem interferir em sua independência ou em sua vida intelectual (CONSTANT, 1991, p. 417).

Em todos esses afastamentos que Constant realiza em relação ao poder conservador de Staël e ao Colégio dos Conservadores de Sieyès, nota-se um esforço de condensar o máximo possível o arbítrio que se trata de incorporar ao sistema institucional, a fim de neutralizá-lo e impedir sua deriva tirânica. Ao passo que Staël e Sieyès haviam pensado seu poder conservador realizando funções direta ou indiretamente legislativas ou governativas, em meio a uma guerra pela consolidação da República, Constant procura isolar o arbítrio necessário para o bom funcionamento do sistema político, mantendo-o afastado de qualquer função legislativa, governativa, judiciária ou ligada à propagação ou ao combate de opiniões. A autoridade discricionária não faria mais do que decidir quando uma assembleia legislativa ou executiva constitui uma ameaça à República, procedendo imediatamente e sem justificativas à dissolução dessa assembleia, e deixando as consequências para serem resolvidas pelos demais atores políticos. Não se trata mais de manter o partido republicano no poder independentemente do resultado das eleições, mas de criar um interesse estruturalmente neutro capaz de decidir legitimamente nas situações em que a ausência de um poder encarregado de decidir empurra os atores políticos ao golpe de Estado.

É verdade que, ao longo do Livro VIII, Constant atribui outras funções ao poder neutro. Sensível à crítica que Necker havia feito à ausência de força real do Senado Conservador, teoricamente tão poderoso, o autor dos Fragments busca atribuir ao poder neutro atividades que tornem sua relação com os cidadãos mais direta e frequente, de modo a retirar sua força da opinião pública. Por essa razão, ele lhe atribui também o direito de graça e de diminuição das penas e o de acolher as petições dos cidadãos contra os atos da autoridade. $\mathrm{O}$ direito de graça e de diminuição das penas pode ser entendido como uma tentativa de Constant de introduzir controladamente o arbítrio no âmbito jurídico-penal, segundo o diagnóstico de que a lei geral pode não ser perfeitamente justa em sua aplicação direta a casos particulares (CONSTANT, 1991, p. 434). Como esse tema é retomado e aprofundado nos Principes de politique de 1806, nós o trataremos mais pausadamente no Capítulo 3 desta tese, quando formos tratar do arbítrio como forma de moderar a inflexibilidade do império da lei, tendo como referência a obra de 1806 . No contexto dos Fragments, cabe destacar que Constant atribui o direito de graça e de diminuição das penas ao poder neutro não apenas para colocá-lo em relação mais direta 
com os cidadãos, mas também porque o direito de graça é uma faculdade de ação discricionária, sendo essa faculdade o atributo definidor do poder neutro. Quanto ao direito de acolher as petições dos cidadãos contra os atos da autoridade, ele se inscreve na função de guardião das liberdades individuais conferida ao poder neutro. Constant atribui também ao poder preservador a mediação das controvérsias entre o poder administrativo (relativo à administração local) e os poderes centrais - uma derivação da função mediadora do poder neutro, cuja essência é decidir se um poder específico ultrapassou seus limites. Além disso, o poder preservador disporia também da faculdade de sancionar ou vetar as modificações constitucionais propostas pelos poderes Legislativo e Executivo - uma faculdade considerada pelo autor como derivada da função de guarda da Constituição, sem que se entravem as melhorias constitucionais derivadas dos progressos do espírito humano.

Embora Constant seja sensível à crítica de Necker sobre a ausência de força real do Senado Conservador, ele continua seguindo a inspiração de Staël e Sieyès de alocar o arbítrio em um poder específico da República. Embora a responsabilidade do Poder Executivo perante o Legislativo seja abordada nos Fragments como uma garantia política importante, o autor acredita, ao contrário de Necker, que ela não substitui inteiramente a possibilidade de destituir imediatamente os membros do Poder Executivo sem nenhum tipo de acusação ou processo - algo que só poderia ser feito pelo poder neutro. A ideia de Necker de fazer de Bonaparte o guardião provisório da Constituição também não é considerada por Constant, que, apesar das referências constantes à situação atual da França, propõe seu plano constitucional como um modelo universal de República para um grande país. Assim, Necker o inspira em sua insistência de assentar os poderes sobre a base sólida da opinião pública, mas não o dissuade da ideia de alocar o arbítrio em uma espécie de Senado Conservador menos poderoso do que o da Constituição do Ano VIII. Constant parece pensar que, sem o acúmulo de poderes do Senado Conservador, seu poder neutro estará melhor apoiado na opinião pública, e suas ações discricionárias pontuais serão mais eficazes do que a guarda da Constituição realizada por uma instituição como o Senado Conservador, com sua neutralidade desnaturada pelo acúmulo de funções. Em suma, o autor procura equilibrar a força do poder neutro, por meio de seu enraizamento na opinião pública, com a impossibilidade de cometer abusos - o que ele vê como um resultado da delimitação das prerrogativas outorgadas a esse poder, as quais não 
ofereceriam nenhuma margem para abusos de autoridade, principalmente por se exercerem sobre poderes e não sobre indivíduos (CONSTANT, 1991, p. 441-442).

Constant termina os Fragments com um trecho já adiantado na Introdução desta tese (cf. p. 27 supra): “Todos os governos precisam de uma autoridade, não ilimitada, mas discricionária. (...). É preciso que essa autoridade discricionária não se aplique nunca sobre os homens, porque os homens devem estar sempre protegidos contra o arbítrio" (CONSTANT, 1991, p. 451). Este trecho resume bem o problema político que ele quer resolver por meio de seu poder neutro: incorporar a autoridade discricionária necessária em todos os governos, sem transformar essa autoridade em um poder ilimitado ou em um arbítrio exercido sobre indivíduos. A solução é um arbítrio pontual exercido sobre poderes, sem que essa autoridade discricionária se imiscua em funções legislativas, executivas ou judiciárias. "Sua autoridade discricionária é, então, puramente preservadora. Se ela se tornasse penal, tratar-se-ia da mais abominável das tiranias" (CONSTANT, 1991, p. 452).

Por fim, o autor conclui que o poder neutro foi o elemento que fez falta nas constituições de 1791 e 1795: na primeira, ele teria evitado a derrubada da monarquia em 10 de agosto de 1792; na segunda, ele teria tornado dispensáveis os golpes de Estado do 18 Frutidor e do 18 Brumário (CONSTANT, 1991, p. 453). Fica evidente, então, que o poder neutro é a resposta formulada por Constant para responder à "prova" do 18 Frutidor. O autor chega a oferecer, no Capítulo 11 do Livro VIII dos Fragments, uma explicação "franca" (CONSTANT, 1991, p. 424) de seu apoio inicial ao golpe, alegando que "nunca uma tentativa havia parecido ser reclamada mais imperativamente pela salvação pública" (CONSTANT, 1991, p. 424), mas demonstrando arrependimento e ponderando que, uma vez violada a Constituição, uma reforma constitucional deveria ter sido feita imediatamente para restabelecer a confiança nas instituições e preencher a lacuna que havia na Constituição do Ano III. Essa lacuna, já anunciada em Des suites de la contrerévolution de 1660 en Angleterre, Constant a elabora sistematicamente nos Fragments: trata-se do poder neutro, a primeira figura da incorporação institucional e controlada do arbítrio em sua teoria política.

Não é esse o modo mais estabelecido de interpretar o poder neutro na bibliografia recente sobre Constant. Stephen Holmes vê no poder neutro de Constant uma simbolização da "imparcialidade geral do próprio Estado, uma imparcialidade que, por sua vez, era concebida como uma condição essencial para a manutenção da discussão e 
do debate públicos" (HOLMES, 1984, p. 145). Por um lado, Holmes ilumina um aspecto importante do poder neutro de Constant: sua elaboração coincide com uma reformulação do pensamento do autor, que, durante o Diretório, fazia uma distinção entre justiça e imparcialidade, recusando que esta última fosse um dever para um governo republicano (cf. p. 78 supra). Pelo contrário, o governo republicano deveria ser parcial em favor da República - tendo sido esse argumento empregado por Constant para defender o 18 Frutidor no discurso do 30 Frutidor. Holmes tem razão ao sublinhar que esse raciocínio é revisto a partir da elaboração do poder neutro nos Fragments: a partir de então, Constant passa, de fato, a buscar um interesse neutro e imparcial para proteger a Constituição, recusando o modelo de ditadura republicana com que ele e Staël haviam flertado. Todavia, Holmes vê no abandono do modelo da ditadura republicana o abandono de toda medida arbitrária, extraconstitucional ou extraordinária (HOLMES, 1984, p. 304, nota 102). Nós sustentamos, ao contrário, que o 18 Frutidor não levou Constant a fechar os olhos para a necessidade do arbítrio e das medidas extraordinárias. Na realidade, a partir de então é que o autor passa a buscar um modo institucional e controlado de realizar essas medidas extraordinárias, decorrentes de decisões discricionárias. O poder neutro é aqui interpretado como a instância por excelência da realização de tais medidas, mais do que como um símbolo da imparcialidade do Estado.

Além disso, a própria noção de neutralidade e imparcialidade do poder preservador, enfatizada por Holmes como sua característica fundamental, deve ser melhor precisada. O poder preservador deve possuir, para Constant, um interesse neutro em relação ao dos poderes Legislativo e Executivo, e ele não deve intervir na disputa de opiniões e doutrinas que ocorre no domínio da sociedade civil, ao contrário das modalidades de poder conservador pensadas por Staël e Sieyès. Isso não significa que o poder preservador deva ser neutro em relação à própria Constituição republicana, pois seu dever é conservá-la, e suas ações discricionárias devem ser movidas por esse objetivo. A inovação de Constant consiste em garantir essa fidelidade à República por meio de um interesse estruturalmente neutro, o qual não desejaria outra coisa além da preservação da Constituição existente, em vez de contar com uma adesão ideológica ao regime republicano por parte dos membros do poder conservador. Esse interesse estruturalmente neutro não implica uma indiferença em relação às formas de governo. Pelo contrário, trata-se de um poder discricionário posto a serviço da conservação de uma forma 
específica de governo, contra os partidos, interesses ou opiniões que ameacem a Constituição estabelecida.

Kalyvas e Katznelson fazem uma interpretação no polo oposto da de Holmes, vendo no poder neutro dos Fragments um modelo de ditadura republicana. Ele seria "dotado de poderes extraordinários, quase ditatoriais" (KALYVAS; KATZNELSON, 2008, p. 158). Esta tese diverge também de Kalyvas e Katznelson, pois enfatizamos que o Constant dos Fragments diverge da Staël de Des circonstances, ao procurar incorporar e neutralizar o arbítrio em um modelo diferente do da ditadura. Embora dotado de uma capacidade de ação discricionária, o poder neutro só poderia exercer as prerrogativas pontuais que a Constituição lhe outorga, não estando, como creem os intérpretes, "localizado acima dos arranjos constitucionais existentes" (KALYVAS; KATZNELSON, 2008, p. 158). Na leitura de Kalyvas e Katznelson, Constant incorpora o arbítrio a sua constituição republicana, mas não faz um esforço para o domesticar e impedir sua deriva tirânica.

Outra interpretação importante do poder neutro é a proposta por Gauchet, primeiramente em seu ensaio "Benjamin Constant: l'illusion lucide du libéralisme" (publicado pela primeira vez em 1980), depois em La Révolution des pouvoirs, de 1995. No primeiro ensaio, o poder preservador é interpretado como uma consequência da percepção de Constant, segundo a qual "o poder não pode ser somente constituído pela sociedade, na medida em que ele tem por papel final constituí-la" (GAUCHET, 1997, p. 99). Inspirado na tradição monarquista, apesar de sua alocação inicial em uma constituição republicana, o poder neutro teria a função de figurar simbolicamente a apreensão última da comunidade política sobre si mesma - uma figuração tornada impossível quando o poder se resume a uma delegação produzida por uma sociedade de indivíduos. Como Holmes, Gauchet enfatiza no poder neutro, mais do que sua faculdade de ação discricionária, sua "neutralidade intelectual" (GAUCHET, 1997, p. 109), imprescindível para dar uma face "à dominação de conjunto, impessoal, da comunidade dos seres sobre sua própria constituição" (GAUCHET, 1997, p. 109).

Em La Révolution des pouvoirs, Gauchet se mostra mais crítico do modo como Constant chega à ideia de poder neutro nos Fragments: "A necessidade desse poder ‘intermediário' (...) não é, de modo algum, derivada da natureza do político; ela é puramente deduzida de uma construção axiomática da garantia, dentro de uma combinação bastante notável de artificialismo e de pragmatismo" (GAUCHET, 1995, p. 
245). O filósofo e historiador contemporâneo vê nessa construção de Constant uma aporia, sublinhando que o próprio autor franco-suíço oscila "quanto à eficácia última de seu dispositivo" (GAUCHET, 1995, p. 249). ${ }^{74}$ A razão do impasse estaria na própria natureza do empreendimento: erigir uma Constituição com base unicamente nos direitos do indivíduo - a tarefa que vinha gerando um fracasso após o outro desde 1789. "Com a lição final de que a ordem política não se deixa reduzir à posição de puro instrumento dos indivíduos. Há necessidades da coisa política e do funcionamento dos poderes de que a dedução dos direitos não dá conta" (GAUCHET, 1995, p. 251). Apenas a partir de 1814, quando Constant abandona a ambição fundadora característica da Revolução Francesa e passa a pensar em modos de limitar a monarquia estabelecida e torná-la compatível com o regime representativo, ele passaria a pensar as necessidades próprias do político para além da órbita exclusiva dos direitos individuais (GAUCHET, 1995, p. 251-254).

Nossa interpretação diverge da de Gauchet, na medida em que encaramos o poder neutro, desde os Fragments, como um modo de Constant responder a uma necessidade própria do político. Essa necessidade é a incorporação do arbítrio, que começa a ser visto pelo autor, após o 18 Frutidor, como indissociável da política - particularmente da resolução das crises políticas. Se o raciocínio de Constant nos Fragments tivesse por único fundamento os direitos individuais, como Gauchet sustenta, ele jamais teria chegado à necessidade de incorporar o arbítrio ao sistema institucional, já que a proteção contra o arbítrio é o mais básico dos direitos individuais. Assim, o poder neutro de Constant não tem por função figurar o domínio reflexivo da comunidade sobre si mesma, mas encarnar o arbítrio fundamental para qualquer ordem política. Seu traço mais essencial não é a neutralidade intelectual, como postulam Gauchet e Holmes. Essa imparcialidade doutrinal é apenas um dispositivo pensado pelo autor para evitar a degeneração da "autoridade discricionária" em um poder tirânico, capaz de perseguir os indivíduos por causa de suas opiniões. Além disso, o poder preservador não é tão neutro assim, pois ele é a favor da Constituição, contra seus inimigos, como acabamos de ver. O traço essencial do poder neutro é, em nossa leitura, a própria faculdade de ação discricionária, mais do que sua imparcialidade intelectual.

${ }^{74}$ Gauchet tem em mente o seguinte trecho aporético dos Fragments: "Quais podem ser, enfim, os abusos do poder preservador? Estes podem ser terríveis. Nenhuma garantia constitucional pode ser estabelecida contra eles. Não se pode dar uma garantia à própria garantia” (CONSTANT, 1991, p. 451). 
No entanto, Gauchet tem razão em sublinhar a aporia em que terminam os Fragments, Constant demonstrando certa ambiguidade em relação à eficácia última de seu sistema. Em nossa interpretação, essa hesitação do autor não se deve à fragilidade de uma construção constitucional baseada exclusivamente nos direitos individuais, como quer Gauchet, mas às dificuldades políticas inerentes à incorporação controlada do arbítrio. Constant notou essas dificuldades nas propostas de Staël e Sieyès, principalmente, buscando um modo de, ao contrário desses autores, condensar o arbítrio em um poder específico que, por sua posição estrutural e pelas prerrogativas à sua disposição, não teria meios de transformar o arbítrio em abuso. Mesmo com todo esse esforço, o autor parece ter dúvidas se esse arbítrio não pode mesmo se transformar em tirania. Em seus escritos seguintes, como veremos, o problema do arbítrio se torna ainda mais complexo, não podendo mais ser concentrado em um poder de Estado específico. 


\section{Capítulo 3: Império da lei e insuficiência da lei nos Principes de politique de 1806}

Este capítulo tem por objeto o lugar do arbítrio nos Principes de politique applicables à tous les gouvernements, escritos por Constant em 1806. ${ }^{75}$ A bibliografia especializada sobre o autor costuma sublinhar esse livro como um ponto de virada importante em seu pensamento, constituindo a primeira formulação sistemática de uma filosofia liberal madura por parte do escritor, a qual, embora não publicada em vida, informa quase todos os seus escritos políticos posteriores, muitas vezes com a reprodução integral de passagens inteiras. Gauchet exprimiu bem por que é a partir dessa obra que podemos falar propriamente em um liberalismo de Constant: ao passo que, até então, seu objetivo político central era a conservação da República (a qualquer custo, podemos dizer em certo sentido), em 1806, sua teoria política se torna mais abstrata e passa a ter como objeto princípios liberais aplicáveis tanto a uma República moderada como a uma monarquia constitucional. Em outras palavras, os princípios da liberdade individual são dissociados das formas de governo (GAUCHET, 1988, p. 951; GAUCHET, 1989, p. 159). A interpretação de 1806 como o momento de uma virada liberal do pensamento de Constant foi sustentada mais recentemente também por Kalyvas e Katznelson, que veem nos Fragments uma obra republicana, baseada no princípio da igualdade e na necessidade de um espírito público ativo para manter a Constituição, e nos Principes de politique uma obra puramente liberal, a qual teria como núcleo a liberdade civil, os direitos individuais, a crítica do princípio da soberania do povo e a limitação do alcance da autoridade social (KALYVAS; KATZNELSON, 2008, Cap. 6). ${ }^{76}$

${ }^{75}$ Neste capítulo, a referência aos "Principes de politique" será sempre ao livro de 1806, nunca ao livro de título semelhante de 1815 (Principes de politique applicables à tous les gouvernements représentatifs et particulièrement à la Constitution actuelle de la France), referido apenas a partir do Capítulo 4 desta tese.

76 Para uma visão alternativa, que propõe o Diretório como o momento da formulação do liberalismo de Constant, ver VINCENT, 2000. Essa disputa sobre quando Constant teria se tornado liberal é mencionada em JAINCHILL, 2008, p. 276, nota 102. 
Essa guinada liberal de Constant pode ser lida em paralelo com um movimento intelectual análogo promovido na mesma época por sua companheira Madame de Staël, ${ }^{77}$ quem, ao longo da década de 1800, passa a formular uma modalidade de teoria política centrada cada vez mais na filosofia moral, culminando com o livro De l'Allemagne, de 1810. Trata-se de uma obra que, em diálogo com a nova escola de filosofia alemã aberta por Kant, faz da liberdade da consciência moral, mais do que da liberdade política propriamente dita, realizada por meio de instituições e do engajamento cívico, o cerne da liberdade a ser gozada pelos modernos. ${ }^{78}$ Essa reorientação do pensamento de Constant e Staël pode ser relacionada à abolição oficial da República e à proclamação do Império napoleônico, em 1804 - um evento que desmotivou a busca pela Constituição republicana mais adequada à França daquele momento, uma busca a que Staël se dedicara em Des circonstances, e Constant, nos Fragments. Em De l'Allemagne, Staël leva essa reorientação do pensamento mais longe do que Constant, chegando a estabelecer um paralelo entre a situação da Europa sob Napoleão e sob o Império Romano, quando o advento do cristianismo teria introduzido uma nova possibilidade de liberdade moral, a qual não consistiria mais na participação nos negócios públicos, mas na obediência à autoridade apenas nas questões que não comprometeriam a consciência e o sentimento do dever. ${ }^{79}$ A mesma busca de um refúgio para a liberdade na consciência moral pode ser encontrada, como veremos, nos Principes de politique de Constant, embora, neste caso, tratasse-se também de consagrar direitos individuais que poderiam sobreviver mesmo à

${ }^{77}$ A relação entre os dois dura cerca de quinze anos, de 1794 ao casamento secreto de Constant com Charlotte de Hardenberg, em 5 de junho de 1808 - casamento que, descoberto por Staël no ano seguinte, provoca o rompimento do casal, embora os diálogos e a relação afetiva entre os dois tenham se prolongado em visitas de Constant a Coppet em 1809 e 1810 (RAYNAUD, 2017, p. 198).

${ }^{78}$ Sobre o papel crucial de De l'Allemagne na trajetória intelectual de Staël, particularmente em sua transição em direção a uma filosofia política autenticamente liberal, ver: JAUME, 1997, p. 39-49; KALYVAS; KATZNELSON, 2008, p. 135-136.

79 “Com exceção do diminuto número de governos livres, a grandeza dos Estados entre os modernos e a concentração do poder nos monarcas tornaram a política, por assim dizer, inteiramente negativa. Trata-se de não se prejudicar uns aos outros. E o governo é encarregado dessa alta polícia, que deve permitir a cada um gozar das vantagens da paz e da ordem social, comprando essa segurança por justos sacrifícios. O divino legislador dos homens ordenava, portanto, a moral mais adaptada à situação do mundo sob o Império Romano, quando ele fazia uma lei do pagamento dos tributos e da submissão ao governo, em tudo o que o dever não proíbe. Mas ele também aconselhava, com a maior força, a vida privada" (STAËL, s.d., p. 503). 
abolição do regime republicano. O autor parece ter se motivado por certos discursos de Napoleão que, em 1806, apontavam para um relaxamento da censura, o que leva Constant a apostar suas fichas em um tratado político que, afastando discussões constitucionais dificilmente toleradas pelo Imperador, teria por objeto direitos subjetivos passíveis de serem consagrados mesmo em uma monarquia - uma aposta rapidamente frustrada, o autor franco-suíço não encontrando as esperadas condições favoráveis para a publicação de seu tratado (cf. GAUCHET, 2005, p.278-279).

Neste capítulo, sugerimos que essa guinada liberal representada pelos Principes de politique leva aquilo que estamos chamando de "problema do arbítrio" a se apresentar sob uma nova configuração. Nos dois primeiros capítulos da tese, o problema do arbítrio estava diretamente associado ao da conservação da República em momentos de crise. O pressuposto de Constant era que "só existe agora um meio de salvação para todo cidadão: o estabelecimento da República" (CONSTANT, 1998a, p. 314), como ele escreve em agosto de 1795 em um dos discursos preparados em colaboração com Louvet para a defesa dos decretos dos dois terços (cf. p. 76 supra). Em outras palavras, a configuração inicial do problema do arbítrio, para o autor, estava ligada a um pressuposto político que não desvinculava a liberdade individual da consolidação do regime republicano. Em certo sentido, suas respostas ao problema do arbítrio miravam um problema análogo ao que a tradição republicana, de Maquiavel a Rousseau, havia procurado resolver por meio da instituição romana da ditadura: como conservar a República quando ela atravessa perigos que não podem ser enfrentados pelo simples seguimento da lei?

O problema do arbítrio muda de direção quando Constant decide fazer dos princípios básicos da liberdade individual o núcleo de sua teoria política. Por um lado, a rejeição categórica do arbítrio volta a se apresentar, uma vez que o abandono das questões relativas ao arranjo dos poderes marginaliza a discussão sobre o poder neutro e, de modo mais geral, sobre a preservação da República em momentos de crise - uma discussão que, como vimos no Capítulo 2, havia levado o autor a rever sua negação absoluta do arbítrio, buscando antes uma maneira de incorporá-lo ao sistema político de modo controlado. Por outro lado, o novo foco nos direitos individuais e na consciência moral leva Constant a refletir sobre a insuficiência das leis para a garantia da liberdade, e essa reflexão traz à tona a necessidade de decisões discricionárias que não derivam das leis ou mesmo as contrariam, de modo a exigir uma incorporação controlada do arbítrio em uma chave diferente da do poder neutro. 
O presente capítulo se divide em cinco seções: Na primeira (3.1), buscamos compreender a nova base teórica da rejeição categórica do arbítrio reeditada nos Principes de politique, sustentando a tese segundo a qual essa crítica do arbítrio efetuada em 1806, embora retomando algumas fórmulas do período do Diretório, baseia-se em uma filosofia política diferente (liberal), a qual não tem mais por fundamento a oposição (republicana) entre lei e arbítrio, mas considera o arbítrio como uma decorrência possível dos excessos da própria lei. Na segunda (3.2), buscamos reconstruir as respostas de Constant, nos Principes de politique, ao problema de como evitar o arbítrio, em um quadro teórico que, ao contrário do dos Fragments, afasta as discussões constitucionais. Na terceira (3.3), argumentamos que a noção de um arbítrio decorrente dos excessos da própria lei coloca o problema de como contornar as leis excessivas, o que reintroduz instâncias legítimas de decisões discricionárias ou arbitrárias que ocorrem à margem ou acima da lei, para além do caso do poder neutro, tratado no Capítulo 2. Na Seção 3.3, será tratado o modo como Constant aborda essas instâncias legítimas de decisão discricionária no âmbito judiciário. Na Seção 3.4, o dever de julgar moralmente as leis antes de se submeter a elas e o direito de desobedecer às leis injustas serão tratados como noções que atribuem a cada indivíduo a faculdade de tomar decisões discricionárias que não decorrem das leis ou mesmo as contrariam, aprofundando o problema da incorporação do arbítrio ao mundo político. Por fim, a Seção 3.5 tratará da relativização histórica dos princípios liberais de liberdade efetuada no Livro XVI ("De l'autorité sociale chez les anciens") dos Principes de politique, argumentando que o arbítrio político é remetido a uma configuração social própria às cidades antigas, nas quais o interesse público vinha antes da segurança e da liberdade individuais. Ao mesmo tempo que essa relativização histórica pinta as sociedades modernas como menos propícias ao arbítrio, ela deixa dúvidas sobre a possibilidade de o eliminar totalmente da vida política moderna. Rejeitando categoricamente o arbítrio quando ele se encontra à mão da autoridade estatal, Constant vê em instâncias de decisão autônoma por parte do indivíduo uma figura positiva do arbítrio, compreendida pelo paradigma do julgamento moral individual.

Do ponto de vista metodológico, este capítulo apresenta algumas diferenças em relação aos dois primeiros, visto que estes últimos procuraram situar o problema do arbítrio na obra do jovem Constant em relação aos discursos políticos que circulavam em seu entorno político-intelectual, de 1795 a 1802, com ênfase nas formulações de Roederer, Lezay-Marnésia, Staël, Sieyès e Necker. Neste capítulo, que tem por objeto 
uma obra mais acabada, com aspiração a uma maior sistematicidade filosófica e um menor debate explícito com questões políticas conjunturais, a leitura interna dos Principes de politique assume um espaço maior do que a investigação da relação de Constant com os atores político-intelectuais de seu entourage, realizada nos dois capítulos anteriores. De modo geral, a ordem de exposição do capítulo segue a ordem dos próprios livros dos Principes de politique, com foco naqueles em que o problema do arbítrio nos parece adquirir maior relevância. Assim, a Seção 3.1 cobre, grosso modo, os Livros I a IV dos Principes de politique; a Seção 3.2, os Livros V e VI; a Seção 3.3, o Livro IX; a Seção IV, o Livro XVIII; e a Seção V, o Livro XVI. Os demais livros não foram julgados tão centrais para o problema do arbítrio, embora trechos relevantes deles sejam citados ao longo do capítulo.

No entanto, embora este capítulo seja, mais do que os outros, estruturado em uma leitura interna de uma obra filosófica, o diálogo de Constant com seus contemporâneos continua sendo um elemento central da investigação, evitando-se transformar suas ideias em um sistema atemporal, e tomando-se as linguagens políticas disponíveis em seu momento histórico como um quadro de referências incontornável para a compreensão do que o autor estava fazendo ao escrever. A principal diferença em relação aos capítulos anteriores é que, tratando-se dos Principes de politique, o diálogo principal de Constant nem sempre é com pessoas de seu círculo próximo (como é o caso de Roederer, LezayMarnésia, Staël, Sieyès e Necker), sendo muitas vezes com filósofos do século XVIII já falecidos ou com pensadores de outros contextos nacionais - caso dos ingleses William Godwin e Jeremy Bentham. Portanto, este capítulo se esforçará para compreender as tomadas de posição de Constant nesse debate com teóricos políticos que transcendem, em alguma medida, o contexto específico da França pós-revolucionária.

\subsection{A nova filosofia política liberal: limitação da soberania e crítica do excesso de leis}

Constant apresenta como o objeto dos Principes de politique o desenvolvimento e as consequências de um princípio

(...) negligenciado pelos escritores de todos os partidos. Montesquieu não se ocupou dele. Rousseau, em seu Contrato social, fundou sua eloquente e 
absurda teoria sobre a subversão desse princípio. Todos os males da Revolução Francesa vieram dessa subversão (CONSTANT, 1980, p. 21).

Esse princípio é, grosso modo, o da limitação da autoridade política e social, em outras palavras, da soberania, mesmo aquela exercida em nome do povo. Segundo a célebre fórmula de Constant:

Há (...) uma parte da existência humana que, necessariamente, permanece individual e independente e que está, de direito, fora de toda competência social. A soberania só existe de modo limitado e relativo. No ponto em que começa a independência da existência individual, termina a jurisdição dessa soberania. Se a sociedade ultrapassa essa linha, ela se torna tão culpada de tirania quanto o déspota que tem por único título o gládio exterminador (CONSTANT, 1980, p. 49).

É a centralidade desse princípio que justifica a interpretação de Gauchet, Kalyvas e Katznelson e outros, segundo a qual os Principes de politique marcam o nascimento de uma filosofia política constantiana autenticamente liberal. Não que a ideia de limitação da autoridade estivesse ausente nos escritos anteriores de Constant. Por exemplo, no Capítulo 7 do Livro VI dos Fragments, o autor critica o fato de as constituições revolucionárias não terem imposto limites ao Poder Legislativo, devido a uma doutrina da soberania do povo como absoluta e ilimitada (CONSTANT, 1991, p. 295). Não obstante, a ideia de limitação da autoridade, no contexto dos Fragments, era passível de uma tradução institucional direta na forma de pesos e contrapesos distribuídos entre os poderes. Assim, as principais medidas para limitar o Legislativo eram o veto do Poder Executivo e a possibilidade de dissolver as assembleias representativas. A principal novidade dos Principes de politique está na apresentação do princípio da limitação da autoridade social como anterior à divisão dos poderes e impossível de ser traduzido institucionalmente de modo completo.

Ao defender a limitação da soberania ou da autoridade social, Constant privilegia o diálogo crítico com Rousseau, de quem ele aceita o "primeiro princípio sobre a fonte da autoridade social" (Capitulo 2 do Livro I dos Principes de politique) - isto é, a soberania do povo, da vontade geral -, mas de quem ele recusa o "segundo princípio sobre a extensão da autoridade social" (Capítulo 3 do Livro I dos Principes de politique) - isto é, a autoridade ilimitada da vontade geral sobre a existência individual, cada indivíduo alienando, pelo contrato social, todos os seus direitos à comunidade política. ${ }^{80}$ No entanto,

${ }^{80}$ A crítica de Constant mira a seguinte frase, do Capítulo VI do Livro I d'O contrato social: "Bem compreendidas, essas cláusulas [do contrato social] se reduzem todas a uma só, a saber, a alienação total de cada associado, com todos os seus direitos, a toda a comunidade” (ROUSSEAU, 2006, p. 21). 
o autor sugere que a ilimitação da soberania ou da autoridade social não é uma particularidade da teoria de Rousseau, mas um pressuposto comum a quase todos os escritores políticos modernos, implícita ou explicitamente. Ele cita os exemplos de d'Holbach, Mably e Ferrand, para provar que a autoridade absoluta e ilimitada é uma busca comum a autores do Iluminismo e da contrarrevolução. Por outro lado, a noção de soberania absoluta e ilimitada teria sido contestada por autores como Beccaria, Condorcet, Franklin, Paine e Sieyès. "Mas não parece que a lógica desses escritores tenha causado grande impressão" (CONSTANT, 1980, p. 29).

No fundo, Constant parece ter consciência de que a ilimitação da autoridade social não é um simples equívoco de alguns filósofos, mas um modo quase incondicional de se pensar a política na modernidade, atrelado ao próprio conceito de soberania como poder absoluto, ilimitado e acima das leis. É contra o próprio conceito moderno de soberania que o autor se dirige, remontando a discussão a Thomas Hobbes (Capítulo 7 do Livro I dos Principes de politique), "o homem que mais reduziu intelectualmente o despotismo em sistema" (CONSTANT, 1980, p. 39). Desse modo, a crítica de Constant à soberania absoluta e ilimitada revela uma relação ambígua do autor com a modernidade política, a qual se reflete em algumas disputas entre seus comentadores. Gauchet interpreta Constant como um dos primeiros grandes intérpretes da modernidade - dessa enorme transformação que faz emergir uma sociedade civil e indivíduos que se concebem como o fundamento do poder político, não mais seu resultado -, sua ideia principal sendo que "a modernidade é estranhamente inconsciente de si mesma, de sua novidade, de sua originalidade fundamental em relação às sociedades anteriores" (GAUCHET, 1997, p. 47): daí a fascinação dos revolucionários franceses pelos modelos anacrônicos do legislador antigo e do déspota esclarecido, capazes de moldar inteiramente a sociedade segundo a sua vontade, por meio da lei. Manent, por outro lado, vê na crítica de Constant a Hobbes uma prova de que a causa última dos fenômenos despóticos denunciados pelo autor liberal (o Terror e o Império napoleônico, principalmente) não era a imitação anacrônica da cidade antiga, mas o conceito moderno de soberania (MANENT, 1980, p. 488-490).

Embora essa disputa entre Gauchet e Manent aponte para uma ambiguidade real da relação de Constant com a modernidade política, podemos afirmar que sua relação específica com o conceito de soberania (seja esse conceito interpretado como de origem moderna ou como uma interpretação anacrônica da cidade antiga) era carregada de tensão, 
beirando a rejeição completa do conceito. No artigo "De la souveraineté", publicado em 12 de fevereiro de 1830 na revista Le Temps, após reproduzir o argumento principal dos Principes de politique e reiterar que "não há soberania ilimitada nem abnegação total. Há soberania limitada, abnegação parcial, e a soberania se torna usurpação quando excede sua competência" (CONSTANT, 1989, p. 101), o autor adota uma postura mais incisiva contra o próprio conceito de soberania: "Excluamos de nosso vocabulário a palavra soberania propriamente dita. Há, na sociedade, necessidades a satisfazer, faculdades a exercer, liberdades a garantir. A soberania ilimitada não existe em parte alguma" (CONSTANT, 1989, p. 102). Desse modo, Constant oscila entre uma noção de soberania limitada (predominante nos Principes de politique) e uma rejeição completa do conceito de soberania, apresentada de modo mais claro no fim de sua vida. A noção de soberania limitada é, sem dúvida, paradoxal, uma vez que o sentido comum do conceito de soberania aponta para um poder ilimitado, acima de todos os outros poderes. É esse paradoxo que, provavelmente, leva o Constant de 1830 a propor a exclusão da palavra "soberania" do vocabulário político. Por outro lado, o autor vê um aspecto fundamental no princípio da soberania do povo: ele indica que a única fonte legítima do poder é a vontade geral (é o que ele chama de "primeiro princípio de Rousseau sobre a fonte da autoridade social”) - um princípio cuja negação implicaria conceder legitimidade à força ou ao privilégio do pequeno número. É essa ideia que leva Constant a manter a palavra "soberania", embora no oximoro "soberania limitada". A operação conceitual é tornar o princípio da soberania do povo não mais um princípio de liberdade, mas um princípio de garantia: "Ele se destina a impedir um indivíduo de se apoderar da autoridade que só pertence à associação inteira; mas ele não decide nada sobre a natureza dessa autoridade" (CONSTANT, 1980, p. 28).

De todo modo, a nova ênfase sobre a necessidade de limitar a soberania do povo engendra uma nova maneira de apresentar aquilo que estamos chamando, nesta tese, de "problema do arbítrio", como já adiantamos na introdução deste capítulo. A proteção contra o arbítrio é, antes de mais nada, nos Principes de politique, um dos direitos subjetivos fundamentais que o indivíduo não poderia jamais alienar à comunidade, de modo a constituir um dos limites necessários à extensão da soberania. Com efeito, os direitos fundamentais do indivíduo são, para Constant, a liberdade de religião, a de pensamento e de sua expressão, e "a certeza de não ser tratado de modo arbitrário, como se tivéssemos excedido os limites dos direitos individuais, ou seja, a garantia de não ser 
preso, detido nem julgado, a não ser de acordo com as leis e segundo as formas" (CONSTANT, 1980, p. 58). Dessa maneira, o autor reata com a crítica implacável do arbítrio, a qual constitui uma das marcas registradas de seus escritos desde o Diretório, e também com toda uma tradição, republicana e liberal, que pensa a liberdade pela fórmula da "não dominação", ou da proteção contra poderes arbitrários. ${ }^{81}$ Todavia, essa retomada do topos anti-arbítrio se funda a partir de então, como veremos, em uma filosofia política diferente (liberal), a qual põe em questão a oposição republicana clássica entre a lei e o arbítrio, subjacente a seus escritos e discursos anteriores.

A crítica do arbítrio formulada por Constant durante o Diretório encontra um ponto de referência significativo no discurso ao Cercle constitutionnel de 27 de fevereiro de 1798 (9 Ventôse do Ano VI), já mencionado no Capítulo 2 desta tese (cf. p. 137 supra). Nesse discurso, o arbítrio é equiparado à ilegalidade, devendo ser prevenido por leis severas, mas precisas; rigorosas, mas fixas. O que estrutura o discurso é a oposição republicana clássica entre lei e arbítrio. Naquela altura, Constant não clamava por menos leis regulando a conduta individual, mas por leis claras e fixas o suficiente para impedir qualquer ação "arbitrária", ou seja, não regulada por nenhuma lei. Os republicanos,

${ }^{81}$ A compreensão da liberdade como ausência de dominação, entendendo por isso a proteção contra poderes arbitrários análogos aos que um senhor possui sobre um escravo ou um servo, tem sido reivindicada por teóricos neorrepublicanos como o conceito de liberdade próprio à tradição republicana, em contraste com a concepção liberal da liberdade como ausência de interferência. A principal sistematização dessa distinção entre os conceitos republicano e liberal de liberdade foi formulada por Philip Pettit (PETTIT, 1997), encontrando uma correspondência em trabalhos de Quentin Skinner (SKINNER, 1998; SKINNER, 2002b). No entanto, a oposição entre republicanos e liberais sustentada por Pettit e pelos teóricos neorrepublicanos de modo geral, embora faça sentido na teoria política normativa contemporânea, é muito problemática quando aplicada ao contexto histórico dos séculos XVIII e XIX, quando as linguagens republicana e liberal se encontravam, geralmente, entrelaçadas nos mesmos autores (KALYVAS; KATZNELSON, 2008; JAINCHILL, 2008). Quanto à classificação de Constant, Pettit incorre no erro iniciado por Isaiah Berlin e já comentado na Introdução desta tese, qual seja, compreender a "liberdade dos modernos" de Constant como uma prefiguração da "liberdade negativa" do próprio Berlin - ou seja, como uma concepção de liberdade que se limitaria à ausência de intervenção, podendo ser gozada por indivíduos que se encontram sujeitos ao poder arbitrário de um senhor. O fato de Constant incluir a proteção contra o arbítrio como um componente fundamental da liberdade desmente essa associação iniciada por Berlin, e reiterada por seus críticos neorrepublicanos, entre a liberdade dos modernos constantiana e a liberdade negativa berliniana. Para Constant, a liberdade individual incluía ao mesmo tempo ausência de interferência e de dominação. 
afirmava o autor à época, não tinham por ideal a independência individual, mas a segurança, garantida pela severidade das leis na austera Esparta (CONSTANT, 1998a, p. 595; cf. p. 138 supra).

Nos Principes de politique, a noção de limitação da autoridade social torna mais complexa a compreensão do arbítrio. A autoridade arbitrária é entendida acima de tudo como aquela que não é limitada em sua área de atuação: "Façam-na sem limites, e vocês recairão no abismo incomensurável do arbítrio" (CONSTANT, 1980, p. 67). Assim, a fonte primeira do arbítrio não é mais o poder que não se regula pela lei, mas o poder que se estende para além de sua alçada (os assuntos de interesse comum), ficando em segundo plano os meios que o governo utiliza nessa intromissão nos assuntos individuais. Esses meios "são de duas espécies: as leis proibitivas ou coercitivas, e os atos chamados de medidas de polícia nas circunstâncias ordinárias, golpes de Estado nas circunstâncias extraordinárias" (CONSTANT, 1980, p. 77). As ações da autoridade, fora de sua esfera de atuação legítima, pelo primeiro meio (as leis), constituem o objeto do Livro IV ("De la multiplicité des lois") dos Principes de politique; pelo segundo meio (medidas de polícia e golpes de Estado), constituem o objeto dos Livros V ("Des mesures arbitraires”) e VI ("Des coups d'État"). O segundo meio é o que recebe diretamente o nome de "medidas arbitrárias" (mesures arbitraires). Contudo, queremos enfatizar que a multiplicidade de leis passa a ser tratada como outra fonte de arbítrio, mais comum nos governos populares. Com isso, a oposição republicana clássica entre lei e arbítrio é rompida, e a nova filosofia liberal dos Principes de politique passa a considerar a própria lei como fonte de arbítrio, quando ela extravasa a esfera em que deveria se encerrar.

O Livro IV ("De la multiplicité des lois") é central para essa reformulação da filosofia política de Constant que passa a considerar a lei como possível fonte de arbítrio. A multiplicidade de leis é caracterizada como "a doença dos Estados que se pretendem livres, porque, nesses Estados, exige-se que a autoridade faça tudo pelas leis" (CONSTANT, 1980, p. 78). A tendência dos Estados livres e dos governos populares à multiplicidade de leis se deveria, em parte, à própria concepção republicana clássica que opõe a lei ao arbítrio e faz da primeira o vetor principal da liberdade. A seguinte citação ilustra bem o afastamento de Constant em relação a esse paradigma republicano clássico que havia sido o seu até então:

Dissemos que a multiplicidade de leis era a doença dos Estados pretensamente livres. Os amigos dos governos populares recorrem a um argumento capcioso para os justificar. Mais vale, dizem, obedecer às leis do que aos homens; é 
preciso que a lei comande, para que os homens não comandem. Sem dúvida, quando se trata de obedecer e quando é preciso que alguém comande. Mas, sobre mil objetos, os homens e a lei devem se calar. Sobre mil objetos, não se deve obedecer nem aos homens, nem às leis (CONSTANT, 1980, p. 85).

Em 1806, diferentemente de 1798, Constant não se contenta em reivindicar leis severas, mas precisas, que não abram portas para o arbítrio. Se, em 1798, o ideal enfatizado era a segurança contra o arbítrio e não a independência individual, este último ideal recebe o destaque principal nos Principes de politique, com impacto determinante para toda a obra posterior do autor. A lei continua sendo vista como importante para impedir a submissão do indivíduo ao arbítrio humano. Porém, a nova ênfase reside nos aspectos da vida individual que não devem sofrer intervenção da sociedade, seja na forma da lei ou do arbítrio. ${ }^{82}$

No Livro IV, a discussão sobre a multiplicidade de leis introduz um aspecto fundamental da filosofia política liberal de Constant: a noção de julgamento moral individual, em conflito com os excessos legislativos. Essa noção é apresentada principalmente no Capítulo 2 do Livro IV, no qual se argumenta que o excesso de leis (mesmo leis regulares, claras, precisas, não retroativas etc.) não apresenta apenas o inconveniente de limitar a liberdade do indivíduo, mas também aquele mais grave de falsear sua moral. Quando a autoridade política ultrapassa a atribuição de proibir as ações prejudiciais por sua natureza e ordenar a execução dos engajamentos contraídos entre os indivíduos, ela intervém sobre um domínio em que só deveria imperar o julgamento da consciência moral de cada indivíduo, provocando a degradação dessa consciência moral:

(...) a moral se torna vacilante e versátil. (...) A regra do justo e do injusto não se encontra mais na consciência do homem, mas na vontade do legislador. E a moralidade, o sentimento interior, experimentam uma degradação incalculável em decorrência dessa dependência em relação a algo estrangeiro, acessório,

${ }^{82}$ É essa nova ênfase nos aspectos da vida individual que não devem sofrer intervenção da sociedade que diferencia a crítica de Constant ao excesso de leis de outras críticas ao mesmo objeto formuladas no século XVIII, inclusive no interior da tradição republicana. Rousseau, por exemplo, considerava que o mais vicioso dos povos era "aquele que tem mais leis" (ROUSSEAU, 1964, p. 493), reiterando uma ideia bastante difundida no século XVIII: a de que o excesso de leis engendra confusão na legislação e enfraquece o próprio império da lei, por meio de uma multidão de leis contraditórias que, em geral, não são seguidas nem sequer conhecidas pelo conjunto dos cidadãos. Um argumento similar pode ser encontrado em MABLY, 1792, p. 247 e 260-262, e, de modo geral, na tradição do "iluminismo penal" a ser abordada mais adiante. Alguns argumentos de Rousseau, Mably, Beccaria etc. contra o excesso de leis são empregados por Constant, mas sua nova ênfase, ausente nesses autores, é no excesso de leis como um empecilho à liberdade individual, não ao próprio império da lei e à coesão da comunidade política. 
artificial, variável, suscetível de erro e de perversão (CONSTANT, 1980, p. 84).

Percebe-se, assim, que o verdadeiro objeto da filosofia política liberal desenvolvida nos Principes de politique é a consciência moral do indivíduo, composta por sua vontade e seu julgamento. O principal problema da multiplicidade de leis estaria no sufocamento dessa consciência moral pela existência civil, política e legal do indivíduo:

\begin{abstract}
Fizeram para a vida inteira do homem o que haviam feito as constituições para as assembleias primárias. Foram redigidas atas de antemão, nas quais só se deixaram em branco o nome e a data, e as quais a espécie humana se resigna docilmente a reproduzir em todas as suas ações. Os homens, hoje em dia, não fazem nada por si mesmos. Para as ações íntimas, há dogmas religiosos positivos. Para as ações exteriores, há a lei. Assim, quando a lei ou a religião se esfacela, os homens não têm mais guia e não sabem mais o que devem fazer (CONSTANT, 1980, p. 532).
\end{abstract}

É a centralidade normativa do julgamento moral individual que leva Jaume (1997) a denominar o pensamento de Madame de Staël e Constant como um "liberalismo do sujeito". Sua interpretação enfatiza a influência de Kant sobre os autores do grupo de Coppet: o liberalismo de Staël e Constant oporia o sujeito moral kantiano, imbuído de uma consciência do dever que atribui a si mesma princípios universais, ao indivíduo maximizador de utilidade benthamiano (cf. JAUME, 1997, p. 94) ${ }^{83}$ A influência de Kant sobre Constant é enfatizada também por Kahan (2018). Na Seção 3.4, exploraremos a maneira peculiar como Constant, a exemplo do que faz explicitamente Staël em De l'Allemagne, procura conciliar o racionalismo moral kantiano com uma teoria do sentimento, e particularmente do sentimento religioso, como fonte da consciência moral. Antes disso, é importante discutir outra influência determinante na maneira como nosso autor concebe o "julgamento privado" como o fundamento de sua filosofia política liberal: a influência do teórico político radical inglês William Godwin, ressaltada por Rosenblatt (ROSENBLATT, 2008, p. 122-134).

Como se sabe, Constant se dedicou, entre 1798 e 1800, a traduzir a obra do autor inglês, Enquiry Concerning Political Justice, de 1793, desistindo posteriormente de publicar a tradução. Em 1810, ele escreve o artigo "De Godwin, de ses principes, et de son ouvrage sur la Justice politique", publicado, com algumas modificações, no Mercure de France, em 1817, e nos Mélanges de littérature et de politique, em 1829. Apesar de

${ }^{83}$ Sobre a oposição, fundante da filosofia moral moderna, entre kantismo e utilitarismo, ver: CANTO-SPERBER, 2005. 
alguns elogios, predomina nessas três versões do artigo o tom crítico em relação à obra de Godwin. Isso não deve nos impedir de notar a importância do autor inglês como fonte de inspiração para Constant, seja de modo direto ou como interlocutor privilegiado em um debate crítico. ${ }^{84}$

Como nota Rosenblatt, é de Godwin que Constant extrai a centralidade do "julgamento privado" (private judgement), traduzido por ele como "julgamento individual" (jugement individuel). "O único meio de discernir a justiça é o exercício do julgamento individual" (CONSTANT, 1998b, p. 111), podemos ler em sua tradução de Godwin. ${ }^{85}$ Para o autor inglês, a verdadeira justiça deriva do julgamento individual

${ }^{84}$ Os estudiosos costumam lançar algumas indagações sobre os motivos que levaram Constant a se empenhar na tradução da obra de Godwin e depois desistir de publicar a tradução. Judith Shklar sublinha a distância entre Constant e Godwin, argumentando que os comentários do primeiro sobre o segundo demonstram "como o liberalismo do século XIX emergiu da era revolucionária e como ele se definiu negando sua herança radical" (SHKLAR, 1973, p. 486). Barberis, por outro lado, vê motivos políticos táticos na decisão de publicar uma tradução de Godwin: Constant buscava fazer um aceno aos neojacobinos que ganhavam relevância no Segundo Diretório, mas mostrar, ao mesmo tempo, que era possível ser politicamente radical sem endossar a violência e as medidas arbitrárias (BARBERIS, 1998c, p. 39-43). Esse objetivo político tático perde sentido após o 18 Brumário afastar a sombra do jacobinismo, levando o tradutor a desistir da publicação, como o próprio Constant sugere em seu artigo sobre Godwin (CONSTANT, 1998b, p. 1418-1419). Mas Barberis sugere que Constant manifesta também um interesse intelectual genuíno pela obra de Godwin, aproximando-se do autor inglês em três pontos principais: a concepção individualista do social, a noção de perfectibilidade do gênero humano e o modo intelectualista de conceber essa perfectibilidade, o progresso moral e político sendo movido pela difusão das luzes (BARBERIS, 1998c, p. 48-53). Bertrand Binoche aprofunda a importância de Godwin para a formulação do pensamento de Constant, argumentando que foi no autor inglês que o franco-suíço encontrou "uma interpretação individualista do homem da Declaração dos direitos que devia tornar para sempre impossível sua absorção terrorista no cidadão" (BINOCHE, 2007, p. 128; ênfases do autor), assim como uma concepção reformista de perfectibilidade indefinida, a qual recusa toda violência feita ao tempo com o propósito de adiantar um progresso institucional que ainda não é aceito pela opinião pública (BINOCHE, 2007, p. 168).

${ }^{85}$ Godwin será citado agora sempre com base na tradução realizada por Constant. Nos trechos citados nesta tese, foi verificado que Constant não distorceu o sentido presente na versão inglesa original do livro de Godwin. Suas maiores intervenções sobre o texto referem-se a modificações na ordem dos capítulos e supressões de certas passagens com fins estilísticos - operações recorrentes nas traduções realizadas nos séculos XVIII e XIX. De todo modo, para os fins desta tese, o que interessa não é tanto o pensamento de Godwin em si, mas antes sua apropriação por Constant, de modo que a leitura que o francosuíço fez do inglês importa mais do que o que o inglês de fato escreveu. O mesmo valerá para Bentham. 
esclarecido e não da lei. Por isso, à medida que o espírito humano progride, dever-se-iam esperar cada vez menos leis e um papel cada vez mais proeminente reservado ao julgamento individual, até a humanidade chegar ao estágio em que as leis e o governo não seriam mais necessários, os seres humanos podendo conviver unicamente com base nas determinações do julgamento moral individual. "Um governo qualquer é sempre um mal, uma usurpação sobre o julgamento particular e sobre a consciência individual da espécie humana" (CONSTANT, 1998b, p. 139). Constant divergirá dessa utopia protoanarquista de Godwin, argumentando que o governo não é um mal quando se atém a sua esfera de atuação legítima, não havendo, portanto, motivos para conceber o desaparecimento do governo e das leis (CONSTANT, 1998b, 1416-1417). Mas ele não deixará de ser sensível à sugestão de Godwin de que as leis são um mal na medida em que tolhem as determinações do julgamento individual. Embora ele não deseje, como o autor inglês, o desaparecimento gradual das leis, ele postula, como o autor inglês, que as leis só são legítimas nos domínios em que o julgamento individual não seria tolhido.

Essa crítica da multiplicidade de leis como fonte de arbítrio leva Constant a buscar uma primeira garantia contra o arbítrio na precaução contra o acúmulo de leis ao longo do tempo. No Capítulo 5 do Livro IV dos Principes de politique, ele argumenta que essas leis acumuladas ao longo dos anos oferecem aos governos tirânicos um arsenal precioso de meios de opressão. O governante sem propensão à tirania pode até ignorar as leis bárbaras e iníquas, mas mesmo isso é um convite ao arbítrio, pois toda a legislação é submetida, nesse caso, ao julgamento do Poder Executivo: "tudo se torna arbitrário em seus atos " (CONSTANT, 1980, p. 89). O remédio que o autor propõe a esse mal é o estabelecimento de "uma revisão periódica e necessária de todas as leis em épocas fixas" (CONSTANT, 1980, p. 89), com o objetivo de impedir a multiplicação indefinida das leis e fechar as portas que essa multiplicação abre para o arbítrio. Os meios de prevenir o arbítrio são aprofundados nos Livros V e VI, dedicados, como já adiantamos, à análise das medidas arbitrárias propriamente ditas. É preciso, entretanto, levar em consideração o encadeamento entre esses três livros dos Principes de politique, visto que, para o Constant de 1806, o arbítrio pode decorrer do excesso de leis ou dos excessos da lei.

\subsection{Medidas de polícia e golpes de Estado}


Os Livros V e VI dos Principes de politique constituem a parte específica da obra que tem por objeto determinado o arbítrio, ou antes as "medidas arbitrárias" - ou seja, as intervenções da autoridade social fora de seu limite de atuação legítima que não têm por meio a lei, como na multiplicidade de leis, mas as "medidas de polícia" e os "golpes de Estado". Se a multiplicidade de leis havia sido caracterizada como a doença dos Estados que se pretendem livres, "a ausência de leis, as medidas de polícia, os atos arbitrários são a doença dos governos que não têm a pretensão de ser livres, porque, nesses governos, a autoridade faz tudo pelos homens" (CONSTANT, 1980, p. 78). Assim, nesses livros, Constant se defronta mais diretamente com o passado monárquico da França, já que as medidas de polícia e os golpes de Estado, segundo a sua conceituação, são mais típicos de monarquias do que de repúblicas, embora essa herança do passado monárquico se reflita na experiência conturbada da Revolução Francesa.

Os Livros V e VI são, desse modo, aqueles em que o problema do arbítrio é tratado de modo mais direto. Isso significa que essa é a parte dos Principes de politique em que a crítica de Constant ao arbítrio é levada ao auge da sistematização conceitual e da expressão retórica, sendo também aquela em que o autor fornece de modo mais explícito respostas à questão de como suprimir o arbítrio da ordem política. Esta seção do capítulo explorará essas respostas de Constant ao problema de como suprimir o arbítrio, assim como algumas das estratégias retóricas mobilizadas na condenação implacável das medidas arbitrárias e dos golpes de Estado. Entretanto, sublinharemos a insuficiência dessas respostas fornecidas por Constant - insuficiência percebida em parte pelo próprio autor -, de modo que os Livros V e VI não oferecem uma solução definitiva ao problema do arbítrio. Pelo contrário, a leitura de todo o Capítulo 3 desta tese evidenciará que aquilo que estamos chamando de "problema do arbítrio" não se restringe aos Livros V e VI dos Principes de politique, mas extravasa para o conjunto da obra.

No Livro V, Constant se coloca o objetivo de refutar os argumentos em favor da utilidade das medidas arbitrárias ou de polícia em certas circunstâncias. Ele vê a França como um país que nunca atribuiu "importância suficiente à segurança individual" (CONSTANT, 1980, p. 93), sendo necessário demonstrar de modo cabal o perigo de medidas arbitrárias naturalizadas pelos diversos regimes políticos por que passou a nação. Assim, no Capítulo 2 do Livro V, o autor contesta a utilidade das medidas arbitrárias para manter a ordem e prevenir os crimes, advogada pelos que argumentam que é melhor prevenir os delitos do que os punir. Nesse debate, Constant fornece uma primeira fórmula 
para a prevenção do arbítrio: "Para tornar o direito de prevenir admissível, é preciso ainda distinguir a jurisdição da autoridade sobre as ações de sua jurisdição sobre os indivíduos. É nessa distinção que se encontra o preservativo contra o arbítrio " (CONSTANT, 1980, p. 97). Ou seja, o governo poderia proibir ações inocentes por temer nelas resultados perigosos, mas o arbítrio nasceria quando o alvo da medida repressiva não são ações definidas pela lei, mas grupos de indivíduos. O principal exemplo que o autor tem em mente são as medidas arbitrárias que a França revolucionária adotou contra membros da nobreza e do clero, punindo-os independentemente das ações que eles cometeram como indivíduos. ${ }^{86}$ Desse modo, o primeiro modo de prevenir o arbítrio exposto por Constant é nunca adotar medidas repressivas contra classes de indivíduos, mas apenas contra ações especificadas pela lei.

É interessante prestar atenção à retórica empregada pelo autor contra os que veem as medidas arbitrárias como úteis, ou pelo menos inofensivas para a massa de cidadãos apáticos e pacíficos. Constant procura demonstrar que o arbítrio, ainda que inicialmente pontual, tem a tendência de se generalizar pelo corpo social, atingindo até os indivíduos que se acreditavam a seu abrigo por viverem uma vida tranquila e afastada da política. "Quando o arbítrio é tolerado, ele se dissemina gradualmente entre tal quantidade de agentes, que o cidadão mais desconhecido pode encontrar o poder nas mãos de seu inimigo" (CONSTANT, 1980, p. 98), escreve o autor no Capítulo 3 do Livro V dos Principes de politique. A estratégia retórica é tornar o arbítrio temível para o cidadão ordinário e distante do centro do poder, receptor usual do discurso segundo o qual o arbítrio é útil para assegurar a ordem e afastar os criminosos.

Essa condenação implacável do arbítrio faz Constant retornar a uma temática que ele já havia explorado em seus escritos do Primeiro Diretório e em seus discursos no Tribunato, de 1800 a 1802, quando ele se opõe às leis de urgência, aos tribunais extraordinários e às tentativas do governo consular de flexibilizar o seguimento das leis em matéria de repressão criminal e política (CONSTANT, 2005a; cf. p. 139 supra). Esse retorno de Constant à retórica anti-arbítrio dos escritos diretoriais e dos discursos no

${ }^{86}$ Contemporaneamente, Patrice Gueniffey desenvolve uma interpretação do Terror alinhada à de Constant, definindo as primeiras medidas terroristas da Revolução Francesa como sendo aquelas que, a partir de 1791, criminalizam os emigrados e os clérigos refratários como grupos da população, independentemente dos atos hostis que eles viessem a cometer como indivíduos (GUENIFFEY, 2000, p. 166). 
Tribunato se liga a um afastamento da discussão constitucional dos Fragments, em que, como procurou mostrar o Capítulo 2 desta tese, ocorre uma incorporação controlada do arbítrio ao sistema institucional por meio do poder neutro, em resposta ao teste do 18 Frutidor. Uma nota das adições aos Principes de politique, encontradas no manuscrito de Lausanne, confirma que, ao condenar implacavelmente o arbítrio nos Livros V e VI, Constant pensou em nuançar essa condenação expondo suas ideias sobre o poder neutro, o qual poderia, segundo os Fragments, agir arbitrariamente sobre os poderes, mas não sobre os indivíduos: "Será necessário, neste capítulo, indicar brevemente a diferença entre as medidas a se tomar contra os poderes e contra os indivíduos, e estabelecer algumas ideias sobre o poder neutro ou preservador" (CONSTANT, 1980, p. 650). ${ }^{87}$ Todavia, o autor não deu prosseguimento a essa nota, provavelmente para não se afastar do propósito de tratar os princípios de liberdade isoladamente da discussão sobre as constituições e formas de governo. Consequentemente, o esforço de incorporar o arbítrio ao sistema institucional, empreendido nos Fragments, não se reflete nos Livros V e VI dos Principes de politique, destinados à condenação do arbítrio.

Essa condenação do arbítrio se torna ainda mais contundente no Livro VI, que tem por objeto os golpes de Estado. Na época em que escreve Constant, a principal referência teórica do conceito de golpe de Estado ainda era a obra Considérations politiques sur les coups d'État, escrita pelo teórico francês da razão de Estado Gabriel Naudé, e publicada secretamente, em Roma, em 1639. Naudé definia os golpes de Estado como

(...) ações ousadas e extraordinárias que os Príncipes são obrigados a executar nos negócios difíceis e, por assim dizer, desesperados, contra o direito comum, sem guardar mesmo nenhuma ordem nem forma de justiça, arriscando o interesse do particular, para o bem do público (NAUDÉ, 1667, p. 103; ênfases do autor).

$\mathrm{O}$ autor do século XVII considerava os golpes de Estado como um recurso fundamental a ser colocado nas mãos dos príncipes, desde que estes não abusassem e não banalizassem esse remédio perigoso, mas o utilizassem somente nas circunstâncias raras e extraordinárias em que ele se fizesse necessário. Nessas ocasiões extraordinárias, as regras comuns da justiça e os direitos dos particulares poderiam ser suspensos, cedendo à necessidade urgente da salvação pública, da qual o príncipe seria o guardião. Naudé

${ }^{87}$ Essa nota de Constant reforça a interpretação desenvolvida no Capítulo 2 desta tese, segundo a qual o principal sentido do poder neutro proposto pelo autor nos Fragments é incorporar o arbítrio ao sistema institucional de modo controlado, evitando-se sua deriva tirânica. 
compara frequentemente o chefe do Estado a um médico ou um pai responsável, que precisa por vezes, mas apenas quando isso é imprescindível, amputar um membro de seu paciente ou de seu filho, para lhe salvar a vida. Esse modo de ação, embora violento, seria legitimado pela máxima ciceroniana Salus populi suprema lex (NAUDÉ, 1667, p. 122). Um exemplo sobre o qual o autor discorre é o massacre da noite de São Bartolomeu, em 1572: para ele, a eliminação dos protestantes era uma necessidade pública em função do mal causado pelas guerras de religião, e, se esse golpe de Estado não acabou definitivamente com esse mal, foi porque ele só foi executado pela metade, poupando ainda muitos huguenotes, que continuaram a guerra (NAUDÉ, 1667, p. 177).

Como esclarece Denis Richet (1988), a definição de golpe de Estado desenvolvida por Naudé continua informando o significado da expressão durante a Revolução Francesa e as primeiras décadas do século XIX. A sexta edição do Dictionnaire de l'Académie française, de 1823, por exemplo, define "golpe de Estado" como "medida extraordinária e sempre violenta, à qual um governo recorre quando a segurança do Estado lhe parece comprometida" (RICHET, 1988, p. 41). É sobretudo com o golpe de Luís Napoleão Bonaparte, em 2 de dezembro de 1851, que a expressão "golpe de Estado" começa a assumir um significado mais próximo do empregado contemporaneamente, associandose o conceito a uma tomada violenta ou inconstitucional do poder, ou a ações planejadas que terminam suspendendo violentamente a Constituição e o regime político vigente (RICHET, 1988; BIANCHI, 2016). É, portanto, em diálogo com a herança intelectual de Naudé e, de modo mais geral, da tradição teórica da razão de Estado, que o Livro VI dos Principes de politique deve ser compreendido.

O objetivo de Constant, nesse livro, é refutar a ideia, popularizada por Naudé e outros teóricos da razão de Estado, segundo a qual a finalidade da salvação pública pode justificar atentados contra a justiça, as leis e os direitos dos indivíduos. ${ }^{88} \mathrm{O}$ autor francosuíço apenas expande a discussão para um horizonte mais amplo do que o contexto monárquico considerado por Naudé, de modo a abarcar qualquer situação, seja em uma monarquia ou em uma república, em que o bem público possa ser usado como uma

${ }^{88}$ Staël se dedicará à mesma refutação no Capítulo 13 da Parte III de De l'Allemagne ("De la morale fondée sur l'intérêt national"), negando que a justiça universal possa se curvar perante os imperativos do interesse nacional, e afirmando que "a integridade dos princípios da moral importa mais do que os interesses dos povos" (STAËL, s.d., p. 499), a dignidade da espécie humana estando acima da conservação dos indivíduos de uma nação (STAËL, s.d., p. 500). 
justificativa para a violação dos princípios de justiça e das normas legais. É particularmente eloquente a condenação implacável que Constant faz do assassinato dos irmãos Graco a mando do Senado romano, no Capítulo 1 do Livro VI dos Principes de politique. Sua discussão imediata é com Antoine Ferrand, autor contrarrevolucionário, conhecido como "o Marat branco", que havia reproduzido, em L'esprit de l'histoire, de 1802, argumentos típicos de Naudé (inclusive a fórmula Salus populi suprema lex) para defender o assassinato dos irmãos Graco por fora das vias legais, estendendo o argumento para justificar o massacre de quem quer que ameaçasse realizar uma revolução em um Estado. Ao refutar Ferrand, Constant revive uma polêmica no interior da tradição republicana, dividida historicamente entre autores que, alinhados ao Senado romano, haviam defendido a execução dos irmãos Graco em nome da salvação da República, como Cícero e Tito Lívio, e autores que, como Maquiavel, haviam responsabilizado a ambição desmesurada dos nobres, mais do que a ação dos irmãos Graco, pelo declínio da República Romana (cf. OSTRENSKY, 2019). Constant se filia claramente à linhagem popular e antiaristocrática do republicanismo, sendo mais explícito do que Maquiavel na condenação do assassinato dos irmãos Graco, e atribuindo a essa ação violenta e extralegal do Senado romano a perda da liberdade republicana:

(...) dessa época, deve-se datar sua perda [da República]. Todos os direitos
foram ignorados, toda a Constituição foi derrubada; o povo, por um instante
consternado, logo retomou pretensões fortalecidas pela vingança. Ele só havia
reivindicado a igualdade dos privilégios. Ele jurou o castigo dos assassinos de
seus defensores. O feroz Mário veio presidir essa vingança (CONSTANT,
1980, p. 105).

Após lembrar as consequências funestas de outros golpes de Estado, como a execução sumária e sem julgamento dos cúmplices de Catilina a mando de Cícero e o assassinato de Henrique I de Guise por Henrique III, em 1588, o autor chega à conclusão de que as situações excepcionais de perigo não justificam a violação dos princípios de justiça e das formas legais, nem mesmo nos casos em que essa violação só se aplicaria sobre um único indivíduo. Pelo contrário, essa violação não faria mais do que agravar a situação de perigo, transformando o governo em uma facção e mergulhando a sociedade no caos da guerra civil:

Sem dúvida, apresentam-se às sociedades políticas momentos de perigo que toda a prudência humana tem dificuldade para conjurar. Mas não é pela violência, pela supressão da justiça, trazendo de volta ao estado social o caos do estado selvagem, não é assim que esses perigos podem ser conjurados. É, pelo contrário, aderindo mais escrupulosamente do que nunca às leis estabelecidas, às formas tutelares, às garantias preservadoras (CONSTANT, 1980, p. 106). 
Se, nos Fragments, sob o impacto do 18 Frutidor, percebido por seu meio políticointelectual como inevitável diante das circunstâncias, Constant havia escrito que "a salvação do Estado pode exigir medidas extraordinárias, mas essas medidas só devem se aplicar aos poderes, não aos homens" (CONSTANT, 1991, p. 400; cf. p. 145 supra), nos Principes de politique, o autor retorna ao legalismo anterior ao 18 Frutidor, o qual simplesmente nega que a salvação do Estado possa exigir medidas extraordinárias. Todo o argumento dos Fragments sobre a insuficiência dos meios legais quando os poderes da República conspiram contra a liberdade dos cidadãos, requerendo-se uma autoridade discricionária para neutralizar essa conspiração rapidamente, é ignorado. Agora, a simples observância escrupulosa da lei é apontada como a melhor resposta para as situações de perigo que parecem demandar o arbítrio. Os Principes de politique marcam, assim, um retorno de Constant a uma concepção forte de império da lei, tal como a presente nos escritos anteriores ao 18 Frutidor analisados no Capítulo 1.

Enfim, no Capítulo 3 do Livro VI dos Principes de politique, Constant liga essa concepção reforçada do império da lei a um constitucionalismo explicitamente ancorado na filosofia liberal desenvolvida nos primeiros livros da obra. Trata-se de uma resposta ao problema do arbítrio que atribui a reponsabilidade por esse mal às constituições excessivamente minuciosas. $\mathrm{O}$ excesso legislativo destas últimas passa a se apresentar não somente como uma restrição da liberdade individual, mas também como um convite a violar a própria Constituição: "Estender uma Constituição a tudo equivale a fazer de tudo um perigo para ela" (CONSTANT, 1980, p. 116). ${ }^{89}$ A proposta de Constant, para evitar o arbítrio provocado pelas constituições excessivamente minuciosas, consiste em reduzir o núcleo da Constituição aos princípios fundamentais da liberdade, principalmente a liberdade de religião, de pensamento e de não ser punido arbitrariamente. Todas as disposições que não se referem a esse núcleo básico deveriam ser facilmente modificáveis, de modo que a própria Constituição contivesse os meios de seu gradual aperfeiçoamento. Assim, as deficiências contidas em todas as constituições

${ }^{89}$ A frase já se encontra no Capítulo 9 de Des réactions politiques, de 1797 (CONSTANT, 1964, p. 80), o que demonstra que as bases filosóficas liberais desenvolvidas plenamente nos Principes de politique já informavam os escritos de Constant sob o Diretório. Isso não diminui o fato de que esses fundamentos teóricos liberais só são desenvolvidos sistematicamente em 1806, provocando inflexões no discurso do autor sobre o arbítrio. 
não se tornariam mais causa nem pretexto para golpes de Estado e violações constitucionais, como ocorreu em diferentes momentos da Revolução Francesa.

Em suma, as bases filosóficas liberais dos Principes de politique se traduzem, na discussão sobre o arbítrio, em uma defesa forte do império da lei e em um constitucionalismo que se abre à tendência da espécie humana ao aperfeiçoamento progressivo. Cabe destacar, todavia, que Constant não vê essa resposta ao problema do arbítrio como desprovida de lacunas: "De resto, nossa determinação positiva de não tratar nesta obra nenhuma das questões que se relacionam com as formas de governo nos força a deixar muitas lacunas sem preenchimento e muitas objeções sem resposta" (CONSTANT, 1980, p. 120). O autor tem consciência de que o afastamento de sua discussão sobre o poder neutro, devido à determinação de não abordar assuntos constitucionais, deixou certas lacunas a respeito da necessidade do arbítrio em uma dose controlada, admitida nos Fragments por conta do teste do 18 Frutidor. Veremos, nas seções seguintes, que a mesma base teórica liberal que o leva de volta a uma visão reforçada do império da lei e a uma rejeição total do arbítrio reintroduz o arbítrio em dimensões inesperadas. Se os Principes de politique restabelecem a noção forte de império da lei que havia sido abraçada por Constant durante o Diretório, eles acendem com igual intensidade um debate sobre as insuficiências do império da lei.

\subsection{A incorporação do arbítrio na ordem judiciária: júri e direito de graça}

O raciocínio seguido por Constant até aqui (Livros I a VI dos Principes de politique) conduz a uma relação ambivalente com o império da lei. Se a rejeição absoluta de medidas extraordinárias (entendidas pelas categorias de "medidas de polícia" e "golpes de Estado”) leva o autor de volta a uma concepção forte de império da lei, como argumentamos na Seção 3.2, a base teórica liberal desenvolvida na Seção 3.1 postula os excessos da própria lei como uma possível fonte de arbítrio. Essa possibilidade de o arbítrio se realizar por meio da própria lei implica uma interrogação sobre as maneiras de proteger o indivíduo não apenas contra a tirania dos seres humanos, mas também contra a possível tirania da lei - isto é, da lei injusta e imoral, ou que simplesmente invade uma esfera da vida humana que deveria pertencer à autonomia individual. 
A noção de leis tirânicas é inconcebível fora da filosofia política liberal tratada na seção I. Como vimos na nota 59 do Capítulo 2, mesmo Madame de Staël nega, em Des circonstances actuelles, de 1798, a possibilidade de leis tirânicas em um país sem privilégios ou proscrições (STAËL, 2009, p. 459; cf. p. 127 supra). Nessa época, apesar da crítica às tentativas de imposição do modelo espartano a uma nação moderna, Staël (e também Constant, que acompanhou de perto a escrita do livro) se orientava por uma base teórica rousseauniana, segundo a qual a lei não pode, por definição, ser tirânica quando ela é instituída pela vontade geral e todos os cidadãos são igualmente submetidos a ela. Rousseau considerava absurdo questionar se uma lei, estatuída por todo o povo sobre todo o povo, poderia ser injusta, "porquanto ninguém é injusto para consigo mesmo" (ROUSSEAU, 2006, Livro II, Cap. VI, p. 47). É a nova filosofia liberal baseada na limitação da soberania do povo e no primado do julgamento moral individual que acarreta a consequência embaraçante da possibilidade de leis injustas e tirânicas, ou simplesmente ilegítimas, por procurarem regular algo que só pertence ao indivíduo. Essa possibilidade abala a concepção forte de império da lei sustentada principalmente nos livros V e VI dos Principes de politique, na medida em que a simples observação rigorosa da lei pode agravar a tirania em vez de a remediar, se a lei em questão for nociva à liberdade individual. Assim, a mesma obra que retorna a uma concepção forte de império da lei ao condenar implacavelmente qualquer espécie de medida extraordinária apresenta um questionamento sobre os modos legítimos de flexibilizar o império da lei quando seu cumprimento rigoroso pode resultar em tirania. Passa-se, desse modo, do império da lei à insuficiência da lei, e o arbítrio, renegado nos livros V e VI, passa a ser reincorporado à política sob novas formas.

A primeira instância em que se torna evidente a discussão de Constant sobre a legitimidade de se contornar ou contrariar a lei com base em decisões discricionárias que não decorrem dela é aquela em que se trata justamente de aplicar a lei às controvérsias civis: o âmbito judiciário. É o tema do Livro IX dos Principes de politique, "Des garanties judiciaires". Ao discutir as garantias judiciárias, Constant tem por interlocutores principais autores que, a partir de meados do século XVIII, posicionaram-se pela proteção do indivíduo contra o arbítrio por meio da reforma de um sistema penal tido como irracional, bárbaro e absurdo. Destacam-se, entre esses autores do "iluminismo penal", 90

\footnotetext{
${ }^{90}$ Há também outros termos utilizados pela literatura para se referir a essa corrente intelectual que tem Beccaria como um de seus principais representantes e sistematizadores: "liberalismo penal",
} 
Montesquieu, Cesare Beccaria e, contemporaneamente a Constant, Jeremy Bentham e William Godwin. De Montesquieu a Bentham, nota-se uma tendência à progressiva racionalização das leis como resposta ao perigo do arbítrio.

A oposição de Montesquieu à severidade das penas (MONTESQUIEU, 2005, Livro VI, Cap. IX) e sua defesa de garantias judiciárias como a presunção de inocência (MONTESQUIEU, 2005, Livro XII, Cap. XII), da fixidez dos julgamentos (MONTESQUIEU, 2005, Livro XI, Cap. VI) e da justa proporção entre delitos e penas (MONTESQUIEU, 2005, Livro VI, Cap. XII) fazem dele um dos pioneiros do iluminismo penal. Em O espírito das leis, de 1748, a oposição ao arbítrio judicial se traduz em uma recusa de considerar o Poder Judiciário como um corpo permanente, em condições de aplicar as leis como bem entender:

\begin{abstract}
O poder de julgar não deve ser dado a um senado permanente, mas deve ser exercido por pessoas tiradas do seio do povo em certos momentos do ano, da maneira prescrita pela lei, para formar um tribunal que só dure o tempo que a necessidade requer.
\end{abstract}

Desta forma, o poder de julgar, tão terrível entre os homens, como não está ligado nem a certo estado, nem a certa profissão, torna-se, por assim dizer, invisível e nulo. Não se têm continuamente juízes sob os olhos; e teme-se a magistratura, e não os magistrados (MONTESQUIEU, 2005, Livro XI, Cap. VI, p. 169).

Entretanto, embora Montesquieu pregue julgamentos que não sejam mais do que uma proclamação da letra da lei, sem a intervenção da vontade do juiz, esse imperativo de racionalização do sistema legal e judiciário encontra alguns limites no modo como o autor concebe a monarquia, o regime político por excelência da Europa de seu tempo. Como a monarquia se caracteriza por "poderes intermediários, subordinados e dependentes" (MONTESQUIEU, 2005, Livro II, Cap. IV, p. 26), dotados de prerrogativas e privilégios de diferentes graus, essa forma de governo não poderia ser submetida à mesma simplificação legal esperada de uma república: "Não devemos espantar-nos se encontrarmos nas leis destes Estados tantas regras, restrições, extensões, que multiplicam os casos particulares e parecem fazer da própria razão uma arte" (MONTESQUIEU, 2005, Livro VI, Cap. I, p. 83). Dessa forma, Montesquieu admite, nas monarquias, a existência de privilégios legais, certa contradição na jurisprudência

\footnotetext{
"reformismo jurídico", "liberalismo da moderação penal", "humanismo penal", "liberalismo beccariano", "modernidade penal das Luzes", "liberalismo judicial", entre outros. Ver PORRET, 2016. O artigo de Porret ilumina o papel de destaque de Voltaire como militante desse iluminismo penal iniciado por Montesquieu e sistematizado por Beccaria.
} 
(MONTESQUIEU, 2005, Livro VI, Cap. I, p. 84) e certa latitude para o juiz buscar o espírito da lei quando ela não é precisa, o que não deveria ser admitido nas repúblicas: "Nos Estados monárquicos, existe uma lei: e onde ela é precisa o juiz segue-a; onde ela não o é, ele procura seu espírito. No governo republicano, é da natureza da constituição que os juízes sigam a letra da lei” (MONTESQUIEU, 2005, Livro VI, Cap. III, p. 87). Além disso, o autor considera como uma das prerrogativas distintivas de um monarca o direito de graça, ou poder de perdoar um condenado. As cartas de indulto são interpretadas como "um grande recurso dos governos moderados" (MONTESQUIEU, 2005, Livro VI, Cap. XVI, p. 101), e a clemência do príncipe é vista como necessária nas monarquias, "onde se é governado pela honra, que muitas vezes exige o que a lei proíbe" (MONTESQUIEU, 2005, Livro VI, Cap. XXI, p. 103). Assim, embora Montesquieu abomine um monarca com poder de julgar, o senso político e de justiça do Rei deve poder intervir sobre os julgamentos e abalar a relação exata entre crime e punição. Na pena do autor, certos princípios da monarquia vêm temperar o excessivo racionalismo do iluminismo penal, concedendo um papel ao sentimento incomensurável do príncipe quando se trata de suavizar a pena de algum súdito (jamais quando se trata de agravá-la): "Mas, dir-se-ia, quando se deve punir? Quando se deve perdoar? É algo que se deixa melhor sentir do que prescrever" (MONTESQUIEU, 2005, Livro VI, Cap. XXI, p. 104).

O iluminismo penal se torna mais racionalista com o clássico Dos delitos e das penas, de Beccaria (publicado em Mônaco em 1764), logo tornado a grande referência do programa de reforma penal do século das Luzes. Beccaria afirma prosseguir a luta de Montesquieu contra a crueldade das punições e a irregularidade dos procedimentos criminais, mas ele avança bem mais do que o autor de $O$ espírito das leis na direção de uma simplificação e racionalização sistemáticas do sistema legal, a fim de adequá-lo ao objetivo único de toda associação humana, "a maior felicidade difundida ao maior número" (BECCARIA, 2011, p. 13). ${ }^{91} \mathrm{O}$ autor italiano tem como um de seus alvos principais o poder dos juízes de interpretar a lei, visto por ele como uma fonte inesgotável de arbítrio. Contra esse perigo, ele propõe retirar todo poder de decisão do juiz, transformando sua sentença na conclusão de um silogismo:

Em qualquer caso criminal, o juiz deve partir de um silogismo perfeito, do qual a premissa maior é a lei geral, a premissa menor é a ação conforme ou não a essa lei, e a consequência é a liberação ou a punição do acusado. Um raciocínio

${ }^{91}$ Utilizamos aqui a tradução francesa realizada por Chaillou de Lisy, em 1773, tida como a mais exata, tendo sido esta, provavelmente, a lida por Constant. 
a mais abre a porta à incerteza e à obscuridade, quer o juiz faça esse raciocínio voluntariamente, quer seja forçado a ele (BECCARIA, 2011, p. 16).

A ideia de juízes que consultam o espírito da lei, admitida por Montesquieu nas monarquias, é rejeitada por Beccaria em qualquer situação, assimilando-se a busca do espírito da lei à decisão arbitrária, a qual estabeleceria a irracionalidade e a quebra de uniformidade dos julgamentos, punindo-se com penas diferentes crimes equivalentes. $\mathrm{O}$ aristocrata milanês se afasta ainda de Montesquieu a respeito do direito de graça a ser conferido ao monarca. Ao contrário do autor de $O$ espírito das leis, Beccaria considera que a clemência deve ser uma virtude específica do legislador, mas não do executor das leis. Para o autor italiano, se o príncipe intervém sobre os julgamentos, mesmo com o objetivo de suavizar a aplicação de leis excessivamente severas, ele reintroduz o arbítrio no âmbito penal, fazendo alguns crimes serem punidos e outros não, fomentando o sentimento de impunidade e atacando implicitamente as leis de seu país, diminuindo assim o respeito geral por elas. $\mathrm{O}$ direito de graça sacrificaria a segurança pública em nome da de um particular. Por isso, Beccaria erige a fórmula: "Que as leis e seus ministros sejam, portanto, inexoráveis, mas que o legislador seja clemente, indulgente, humano" (BECCARIA, 2011, p. 63). Em outras palavras, a suavização do sistema penal pregada pelo aristocrata milanês deve estar na feitura da lei, mas sua execução deve ser a mais rigorosa e literal possível, não deixando nenhuma margem para o arbítrio humano.

Na virada dos séculos XVIII e XIX, Bentham se torna o principal expoente da racionalização do sistema legal, procurando fazer da legislação e da moral "uma questão de observação e de cálculo" (BENTHAM, 1830, I, p. 19), ${ }^{92}$ subordinada ao princípio de utilidade. $\mathrm{O}$ autor inglês leva a seu ápice a preocupação com a racionalização e a simplificação do sistema legal, já presente na obra de Beccaria. Seu objetivo é tornar a aplicação das leis imediata, sem nenhuma margem para o arbítrio. Como o autor italiano, Bentham prega leis a tal ponto simples, racionais e conhecidas de todos que não precisem de intérpretes, apenas de executores. "Para dominar a expectativa, é preciso ainda que a lei se apresente ao espírito como devendo ter sua execução, ou, pelo menos, que ela não deixe perceber nenhuma razão que faça presumir o contrário" (BENTHAM, 1830, I, p. 267; ênfases do autor). O arbítrio é entendido como a não execução literal da lei, relacionada, em geral, ao poder que tem o juiz de a interpretar: "Mas, quando o juiz ousa

${ }^{92}$ Estamos citando de acordo com a edição francesa da obra de Bentham publicada por Étienne Dumont em 1802. Ao que tudo indica, essa é a edição lida e citada por Constant. 
se arrogar o poder de interpretar as leis, ou seja, de substituir a vontade do legislador pela sua, o arbítrio está em toda parte, ninguém pode prever o curso que tomará seu capricho" (BENTHAM, 1830, I, p. 271).

Com esse objetivo de garantir a execução literal da lei, Bentham critica, como Beccaria, o direito de graça, comumente atribuído ao Rei como uma das mais nobres prerrogativas da Coroa. Para o filósofo inglês, tudo que torna a execução da pena menos certa é um mal, pois só pode ser compensado com o aumento de rigor da pena. Se o poder de perdoar remedia a aplicação de leis absurdas herdadas de tempos bárbaros, trata-se de uma instituição que só atrapalharia um sistema de legislação adequado, levando o príncipe a se pronunciar periodicamente contra as leis de seu país. Assim Bentham resume a questão:

Se as leis são duras demais, o poder de atribuir graça é um corretivo necessário; mas esse corretivo é ainda um mal. Façam boas leis, e não criem uma varinha mágica que tenha o poder de anulá-las. Se a pena é necessária, não se deve revogá-la; se ela não é necessária, não se deve pronunciá-la (BENTHAM, 1830 , II, p. 211). ${ }^{93}$

Ao discutir as garantias judiciárias no Livro IX dos Principes de politique, Constant se filia até certo ponto ao iluminismo penal representado por Montesquieu, Beccaria e Bentham, entre outros. Seu objetivo principal, ao incluir as garantias judiciárias como um princípio básico de liberdade, é também proteger o indivíduo de um tratamento arbitrário por parte da autoridade, e o autor franco-suíço também é sensível à luta contra a severidade das penas. Não obstante, Constant se afasta desses autores que o precederam em alguns aspectos relevantes para esta tese, na medida em que esses aspectos iluminam uma relação mais complexa de nosso autor com o arbítrio e a aplicação literal da lei. Na raiz desse afastamento de Constant em relação ao iluminismo penal, está

${ }^{93}$ A crítica ao direito de graça é a postura mais comum na tradição do iluminismo penal. Ela pode ser encontrada também em MABLY, 1792, p. 291, com o mesmo argumento de que o direito de graça enfraquece o império da lei e institui o arbítrio. Vale notar que, no Livro III de De la législation, ou principes des lois, de 1776, Mably incorpora vários temas do iluminismo penal, com destaque para a moderação das penas. Extremamente agressivo em relação a Mably, Constant modera o tom para tratar desse Livro III, no qual ele encontra "muitas ideias bastante justas e muitas verdades bastante úteis" (CONSTANT, 1980, p. 452), revelando seu interesse pela tradição do iluminismo penal. A crítica ao direito de graça pode ser encontrada também na obra de Godwin (CONSTANT, 1998b, p. 312-313), como veremos adiante. 
sua preocupação em proteger o indivíduo não apenas do arbítrio governamental, mas também da lei injusta ou tirânica.

Nos Fragments, Constant já havia revelado uma concepção do Poder Judiciário inspirada em Montesquieu, ao apresentá-lo como "poder nulo politicamente" (CONSTANT, 1991, p. 149). Já nesse livro, o autor havia considerado que esse poder "sai de sua nulidade" quando é empregado para erigir barreiras contra os abusos do Poder Executivo, "porque cabe a ele preservar os governados das vexações a se temer da parte dos governantes" (CONSTANT, 1991, p. 333). Tanto no Capítulo 5 do Livro VII dos Fragments como no Capítulo 1 do Livro IX dos Principes de politique, Constant enfatiza a independência do Poder Judiciário como a primeira condição para que ele seja capaz de proteger o indivíduo do arbítrio governamental. Começa aí o afastamento do autor em relação a Montesquieu, uma vez que o autor franco-suíço associa a independência do Judiciário a um espírito de corpo negado pelo autor de $O$ espírito das leis. Como vimos, este havia recusado que o poder de julgar devesse ser um poder permanente pertencente a um corpo, devendo ser exercido por cidadãos comuns selecionados para julgamentos específicos. De acordo com Constant, Montesquieu confunde a função de juízes com a de jurados, além de olhar mais para as repúblicas antigas (especialmente Atenas) do que para o que seria praticável nas nações modernas (CONSTANT, 1991, p. 336-337; CONSTANT, 1980, p. 549-550). Nessas nações, a principal garantia da independência do juiz seria a inamovibilidade, seguida por salários consideráveis que impusessem respeito (CONSTANT, 1991, p. 336) - em suma, o espírito de corpo:

\begin{abstract}
O espírito de corpo é uma das melhores barreiras contra o servilismo em relação ao poder ou às facções, em uma nação em que todo o mundo se deixa guiar pela opinião dominante. Nenhum indivíduo ousa ter uma opinião oposta à de todos. $\mathrm{O}$ espírito de corpo, pelo contrário, coloca-se à frente, e os indivíduos que querem resistir à opinião dominante, assegurados por esse aliado, unem-se a ele. Um corpo judiciário inamovível é necessário para que um juiz não tema, ao julgar segundo a sua consciência, ferir a autoridade sob a qual ele se encontraria como um simples cidadão (CONSTANT, 1980, p. $550)$.
\end{abstract}

Nesse ponto de sua argumentação, a crítica de Constant é dirigida aos revolucionários franceses, acusados, ao tornar os juízes elegíveis e revogáveis (justamente para tornar o Judiciário nulo politicamente), de arruinar sua independência e fazer deles marionetes das facções (CONSTANT, 1991, p. 335-336; CONSTANT, 1980, p. 182). Essa crítica já se encontra presente em Des circonstances actuelles de Staël: “Desde a Revolução na França, os tribunais, os julgamentos, os juízes, nada disso foi livre. Os diversos partidos se apoderaram, um após o outro, das formas, do espírito, dos 
instrumentos da lei" (STAËL, 2009, p. 390). Constant chega a sugerir que havia mais garantias judiciárias na França do Antigo Regime, pois, apesar de todos os abusos, a venalidade dos cargos garantia a independência e a inamovibilidade dos juízes, e os parlamentos eram dotados de um espírito de corpo salutar (CONSTANT, 1980, p. 181182).

Ao defender o espírito de corpo do Judiciário, Constant se afasta da compreensão de Montesquieu do Judiciário como uma simples boca invisível da lei, avançando em direção a uma compreensão que será consagrada por Tocqueville: a do Judiciário como uma espécie de novo corpo aristocrático a moderar os impulsos potencialmente tirânicos da opinião majoritária e, assim, servir de contrapeso à democracia (TOCQUEVILLE, 2005, Parte II, Cap. VIII, p. 308-317). Na linha do iluminismo penal de Montesquieu, Beccaria e Bentham, Constant pensa a garantia judiciária pela chave da proteção do indivíduo contra o arbítrio. Contudo, se a preocupação central desses três autores icônicos do iluminismo penal era, por assim dizer, anular o Poder Judiciário na qualidade de poder específico tomador de decisões, fazendo dele um simples averiguador de fatos particulares e um calculador de silogismos espalhado pelo corpo social, Constant procura, ao contrário, conferir substância ao Judiciário, se não como poder comparável ao Legislativo e ao Executivo, ao menos como corpo dotado de um espírito próprio e de independência para tomar decisões contra a opinião dominante. Se o alvo de Beccaria e Bentham eram os juízes que se sentiam autorizados a interpretar a lei, Constant quer garantir ao juiz a independência necessária para julgar "segundo a sua consciência" (CONSTANT, 1980, p. 550).

Significativamente, o autor escreve que "só se deve temer o espírito de corpo quando a instituição dos jurados não existe” (CONSTANT, 1980, p. 182). A instituição, por excelência democrática, do júri é entendida, primeiramente, como um contraponto ao espírito de corpo potencialmente aristocrático do Judiciário. ${ }^{94}$ Entretanto, não é apenas o

94 Também nesse ponto, Tocqueville será um continuador de Constant, na medida em que realça o caráter republicano e, quando não há restrições de classe para o exercício da função de jurado, democrático da instituição do júri, a qual "coloca o próprio povo ou, pelo menos uma classe de cidadãos na cadeira do juiz" (TOCQUEVILLE, 2005, Parte II, Cap. VIII, p. 319), o que tem por consequência "colocar a direção real da sociedade nas mãos dos governados ou de uma porção deles, e não na dos governantes" (TOCQUEVILlE, 2005, Parte II, Cap. VIII, p. 319). No entanto, Tocqueville não vê a instituição do júri como uma maneira de moderar o poder aristocrático dos juízes, mas, pelo contrário, como um modo de 
espírito de corpo dos juízes o objeto a ser contido pelos jurados, mas, mais profundamente, as leis cuja aplicação literal poderia resultar em tirania e injustiça. O júri é a primeira resposta de Constant ao problema, enunciado no início desta seção, de como proteger o indivíduo da possível tirania das próprias leis. Nessa resposta, a aplicação literal da lei pregada pelo iluminismo penal é contestada, e uma forma controlada de arbítrio volta a ser introduzida no mundo político-legal. Vejamos.

Remontando ao início da Revolução Francesa e, particularmente, à atuação de Adrien Duport na Constituinte, o júri popular já tinha uma história na França antes de Constant. Tratava-se de uma instituição inspirada na prática britânica, a qual fazia, "em geral, a unanimidade do campo liberal como instituição penal necessária a um país livre" (JAUME, 1997, p. 379). Todavia, a defesa do júri empreendida por Constant tinha uma singularidade saliente, a qual foi percebida por Jaume:

(...) ele vai diretamente à distinção que lhe importa, aquela entre a letra e o espírito da lei. Isso equivale a dizer que o júri se situa acima das leis: ele faz o que é proibido mesmo aos juízes especialistas em Direito. Ele se torna um órgão político de resistência às leis injustas, uma representação quase subversiva perante a representação constitucional (JAUME, 1997, p. 393; ênfases do autor).

$\mathrm{O}$ argumento de Constant que fundamenta essa constatação de Jaume é formulado primeiramente em uma adição ao Capítulo 1 do Livro IX dos Principes de politique, sendo depois publicado no Capítulo V das Réflexions sur les constitutions, de 1814, no Capítulo XIX dos Principes de politique de 1815 e no Capítulo X da Terceira Parte de Commentaire sur l'ouvrage de Filangieri, de 1822-1824. O argumento é dirigido contra Gach, autor de Des vices de l'institution du jury en France, de 1804. Para Gach, a instituição do júri não se adequa a um país como a França, cuja falta de espírito público não disporia os cidadãos a exercer de bom grado esse serviço público. Principalmente, o autor formula a crítica elitista segundo a qual o cidadão comum não possui a instrução nem as qualidades morais necessárias para participar do julgamento de outros cidadãos. Os jurados, tirados do seio do povo, não teriam a capacidade intelectual nem a firmeza moral necessárias para fazer abstração das consequências de sua declaração sobre a culpabilidade ou a inocência do acusado. Movidos pela piedade, procurariam julgar a

fundar a influência benéfica do corpo aristocrático dos magistrados sobre o espírito do povo: "o júri, que parece diminuir os direitos da magistratura, na verdade funda o império desta, e não há país em que os juízes sejam tão poderosos quanto aqueles em que o povo participa de seus privilégios" (TOCQUEVILLE, 2005, Parte II, Cap. VIII, p. 323). 
severidade da lei a ser aplicada, desviando-se, assim, da execução exata da lei. Gach utiliza o exemplo de um homem acusado de dar asilo a um irmão assassino condenado à morte. A lei condena à morte não apenas o assassino, mas também seu irmão protetor. Porém, segundo o autor, os jurados não seriam capazes de fazer abstração da situação e perdoariam o homem que deu asilo ao irmão, mesmo contra a lei: “eles não conceberão como se pôde criminalizar um homem por um fato que lhe ordenavam imperiosamente a humanidade, a natureza, e eles se apressarão em absolvê-lo" (GACH, 1804, p. 41). Eis a resposta de Constant:

Esse exemplo, (...) longe de advogar contra a instituição do júri, faz o seu maior elogio. Ele prova que essa instituição coloca um obstáculo à execução das leis contrárias à humanidade, à justiça e à moral. É-se homem antes de ser jurado. Consequentemente, longe de desaprovar o jurado que, nesse caso, pronunciaria contra sua consciência e faltaria assim ao dever de jurado, eu o elogiaria por cumprir o dever de homem e correr, da maneira que estaria em seu poder, ao auxílio de um homem prestes a ser condenado por uma ação que não é um crime. (...)

As penas não devem ser excessivas, e, se elas parecem excessivas aos jurados, é porque o são, pois os jurados não têm nenhum interesse em achá-las assim. (...) quando eles se encontram entre o sentimento da justiça e da humanidade e a letra da lei, não é um mal que eles se afastem dela. Não deve existir uma lei que revolte a humanidade do comum dos homens, a tal ponto que os jurados, tomados do seio de uma nação, não possam se determinar a concorrer à aplicação dessa lei (CONSTANT, 1980, p. 552-553).

Essa citação marca com eloquência o afastamento de Constant em relação ao iluminismo penal tratado acima. Se o autor se une a Beccaria e Bentham na condenação das penas excessivamente severas, ele não se contenta com a reivindicação de um código legal perfeito e racional, em que as penas sejam proporcionais aos delitos, e as leis, sempre justas, devessem ser aplicadas em sua exatidão. Para Constant, as leis tirânicas e injustas são um risco permanente, pois é uma tendência dos poderes políticos abusar de suas funções. Portanto, o indivíduo só estará protegido se seus pares (os cidadãos comuns) puderem contornar a aplicação das leis injustas e desumanas por meio da instituição do júri. Ao defender que o resultado mais justo de um julgamento pode ser a não aplicação literal da lei, o autor se afasta do iluminismo penal de Beccaria e Bentham e abala a concepção forte de império da lei defendida em outras passagens de sua obra. Não se trata de mera incoerência, mas de uma resposta às insuficiências do império da lei apontadas por sua filosofia liberal. O que o autor franco-suíço sublinha é justamente o perigo de uma lei que se aplica ao mundo social de modo automático, sem a mediação da decisão e do arbítrio humanos, como sonhavam o iluminismo penal e a cultura revolucionária da sagração da lei. 
No capítulo 4 do Livro IX dos Principes de politique ("Du droit de faire grâce"), o perigo da aplicação automática da lei é aprofundado. Ao defender o direito de graça, Constant se aproxima de Montesquieu e se afasta de Beccaria, Mably, Bentham e Godwin. Dois outros autores importantes para a formação intelectual de Constant estão na base de seu argumento a favor do direito de graça: Necker e Sieyès. ${ }^{95} \mathrm{O}$ primeiro lamenta, em Du Pouvoir Exécutif dans les Grands États, de 1792, a abolição do direito de graça pela Assembleia Nacional Constituinte, despojando o Rei "da mais augusta de suas prerrogativas" (NECKER, 1792, p. 182). Para o ex-ministro de Luís XVI, o direito de graça é essencial para "misturar aos princípios de severidade um espírito de indulgência, e para suavizar a justiça escrita pela equidade natural” (NECKER, 1792, p. 186-187).

Sieyès, por sua vez, havia proposto, em seu discurso de 18 Termidor do Ano III à Convenção, integrar a seu júri constitucional "um suplemento de jurisdição natural às lacunas da jurisdição positiva" (SIEYÈS apud TROPER, 2006, p. 533). O ex-abade também lamenta a abolição do direito de graça, argumentando que ele foi confundido com uma prerrogativa régia, sendo, na realidade, "a prerrogativa da inocência prestes a sucumbir, com as aparências do crime" (SIEYÈS apud TROPER, 2006, p. 533). Para ele, toda legislação é insuficiente e apresenta lacunas, colocando muitas vezes os juízes diante do terrível impasse entre cometer uma injustiça ou infringir a lei. Mesmo uma legislação perfeita não poderia prever todos os casos particulares a serem regrados pela lei. Por isso, Sieyès propõe que, nesses casos em que a aplicação da lei pareça injusta, os tribunais possam remeter o processo para uma porção do júri constitucional tornada "um tribunal dos direitos do homem" (SIEYÈS apud TROPER, 2006, p. 535), o qual não julgaria de acordo com a lei positiva, mas de acordo com a lei de natureza. O orador assinala o risco de arbítrio inerente a um julgamento não pautado pela lei positiva: "O perigo de cair no arbítrio era a grande, a verdadeira dificuldade que precisávamos vencer" (SIEYÈS apud TROPER, 2006, p. 535). Todavia, ele minimiza esse risco, ao insistir que esse tribunal dos direitos do homem precisaria basear suas decisões na mesma fonte de onde o legislador precisa extrair as leis positivas: no código de leis naturais. "O que é o próprio legislador, senão um juiz de equidade natural? De onde ele extrai suas decisões gerais,

${ }^{95}$ Gauchet (1988, p. 952) considera Necker e Sieyès como as duas principais referências políticointelectuais de Constant, em relação às quais ele sempre busca se situar. Aproximações e distanciamentos entre essas duas figuras fundamentais na formação de Constant são apontados em BREDIN, 2000. 
senão no código de onde eu proponho que se extraiam algumas decisões particulares?" (SIEYÈS apud TROPER, 2006, p. 535). Com base nessa consideração, Sieyès revê o significado comum da palavra arbitraire, concluindo que uma decisão de justiça natural tomada por um tribunal designado para esse fim não é arbitrária mesmo que contrarie a lei, pois o próprio legislador tomaria essa decisão se estivesse mais bem instruído:

Mas permitam-me pausar um instante sobre essa palavra arbítrio: ela tem dois
sentidos que importa distinguir. Vocês tomam o arbítrio pelo exercício de uma
autoridade sem freio, sem regra, sem princípio? Trata-se de algo odioso. Eu
não desejo isso mais do que vocês. Que isso permaneça para sempre
estrangeiro a nossas relações sociais. Mas, se vocês dão esse nome a uma
decisão de justiça natural que seu legislador ainda não soube alocar em seu
código, que, melhor instruído, ele não deixará de alocar amanhã, retirem um
nome desonroso. Trata-se, então, de algo útil, respeitável, e, nesse sentido,
nada é menos arbitrário (SIEYĖS apud TROPER, 2006, p. 535).

Como já vimos no Capítulo 2, Constant atribui, nos Fragments (Livro VIII, Capítulo 13), o direito de graça e de diminuição das penas a seu poder neutro ou preservador, como uma forma de tornar sua relação com os cidadãos mais direta e frequente e, assim, aumentar sua consideração diante da opinião pública. A inspiração de Necker, e mais ainda de Sieyès, é evidente. ${ }^{96}$ Seguindo a argumentação do ex-abade, o autor vê o direito de graça como uma decorrência necessária da insuficiência de toda lei geral diante da diversidade de casos e circunstâncias particulares:

O direito de atribuir graça é indispensável, porque esse direito é apenas, na realidade, o de levar em consideração as circunstâncias de uma ação para decidir se a lei é aplicável. Quanto mais uma lei é geral, mais ela se afasta das ações particulares sobre as quais, todavia, ela é destinada a se pronunciar. Uma lei só pode ser perfeitamente justa para uma única circunstância. Basta ela se aplicar a duas circunstâncias distinguidas pela diferença mais sutil, para ela se tornar mais ou menos injusta em um dos dois casos. Mas, mesmo multiplicando as leis para além de toda medida, vocês não escapariam dessa dificuldade. Os fatos se nuançam infinitamente: as leis não podem segui-los em suas modificações multiformes. Portanto, é um raciocínio absurdo aquele dilema famoso: se a lei é justa, ninguém deve poder entravar sua execução; se ela é injusta, deve-se revogá-la. A lei pode ser justa, como lei geral; ou seja, pode ser justo atribuir tal pena a tal ação; e, contudo, a lei pode não ser justa em sua aplicação a tal fato particular: ou seja, tal ação, materialmente a mesma que a lei tinha em vista, pode diferir dela de maneira real, embora indefinível legalmente. Se vocês desejassem apenas leis que fossem sempre estritamente justas em aplicação, seria necessário haver uma lei para cada fato. (...) O direito de graça ou de comutar a pena não é outra coisa do que a conciliação da lei

${ }^{96}$ Além de Necker e Sieyès, Constant reata, a propósito do direito de graça, com Montesquieu e Locke. Este último advoga - não por acaso, no capítulo sobre a prerrogativa (Capítulo 16 do Segundo Tratado sobre o Governo; ver Capítulo 1 desta tese) - "que o governante tenha o poder, em muitos casos, de atenuar a severidade da lei e perdoar alguns infratores. Pois, sendo o fim do governo a conservação de todos tanto quanto possível, mesmo os culpados devem ser poupados sempre que não resulte daí nenhum prejuízo para os inocentes" (LOCKE, 2005, p. 529-530, §159; ênfases do autor). 
geral com a justiça para cada detalhe (CONSTANT, 1991, p. 434-435; ênfases nossas).

Essa passagem, fundamental para a tese aqui desenvolvida, é retomada no Capítulo 4 do Livro IX dos Principes de politique, no Capítulo II das Réflexions sur les constitutions e no Capítulo XIX dos Principes de politique de 1815. Nos Principes de politique de 1806, o autor ainda acrescenta a seguinte frase: "O direito de atribuir graça ou de suavizar a pena é necessário para compensar a inflexibilidade da lei" (CONSTANT, 1980, p. 193-194).

Com essa consideração, Constant radicaliza sua ruptura com a concepção forte de império da lei que havia marcado o iluminismo penal e a cultura política da Revolução Francesa, entendida por Rosanvallon como uma "cultura da generalidade" (ROSANVALLON, 2004, p. 25-105; ROSANVALLON, 2015, p. 37-49). O autor francosuíço desmonta o "dilema famoso" de Bentham (aplicar literalmente a lei se ela é justa, revogá-la se ela é injusta), sugerindo uma descontinuidade entre os planos da generalidade e da particularidade negada pela cultura da generalidade: uma lei pode ser justa em geral, mas injusta em sua aplicação rigorosa a um caso particular. Essa sugestão de uma descontinuidade entre os planos da generalidade e da particularidade gera um problema para a tentativa que Constant havia efetuado, em Des réactions politiques, de estabelecer uma continuidade entre o geral e o particular por meio da definição de um princípio como "o resultado geral de certo número de fatos particulares" (CONSTANT, 1964, p. 64; cf. p. 22 supra). Em 1797, o autor achava possível conectar qualquer fato particular a um princípio geral, desde que fossem descobertos os "princípios intermediários" que constituem os elos da cadeia de transmissão. A partir dos Fragments, Constant passa a pensar em circunstâncias impossíveis de subsumir com justiça por uma lei geral, requerendo a decisão de um agente moral.

O autor se afasta, assim, do racionalismo iluminista e se aproxima de uma reflexão proposta por Aristóteles, sem uma resposta definitiva: É melhor ser governado pelo melhor homem ou pelas melhores leis? O filósofo grego havia sublinhado a superioridade da lei sobre o ser humano, por ser a lei uma norma universal não pervertida pela paixão, mas havia também indicado a insuficiência da lei, justamente por ser universal, em se aplicar com justiça a todas as circunstâncias particulares. Por isso, mesmo defendendo o império da lei, Aristóteles entendia que havia circunstâncias particulares que não poderiam ser bem decididas pela lei, demandando a deliberação humana - sendo, nesses 
casos em que a lei é insuficiente, a deliberação da multidão superior, em geral, do que a de um só (ARISTOTLE, 1998, Livro III, Caps. 15-16, p. 94-98). Constant segue um raciocínio análogo ao de Aristóteles, argumentando que a lei deve ser a bússola das controvérsias civis e dos julgamentos criminais, mas sua orientação geral não saberia se aplicar com justiça a todos os casos particulares, requerendo propriamente a decisão de uma vontade capaz de averiguar se o caso particular é justamente subsumido pela lei geral. O autor concorda com Beccaria e Bentham de que essa vontade deliberante não pode partir do juiz: "Quando vocês convocam juízes para fazer outra coisa do que ler o texto da lei escrita, vocês desnaturam a função de juiz" (CONSTANT, 1980, p. 194). Contudo, essa vontade capaz de tomar uma decisão deve existir externamente ao juiz, interpondo-se entre a lei geral e sua aplicação particular. ${ }^{97}$

Como vimos, filósofos do iluminismo penal como Beccaria e Bentham veem o espectro do arbítrio justamente nessa intromissão de uma vontade deliberante em um julgamento. Para eles, o arbítrio só pode ser extirpado se não houver propriamente decisão a tomar, apenas uma lei a ser executada. O próprio Sieyès havia reconhecido, como vimos, que decisões judiciais contrárias à lei positiva constituem um dos dois sentidos atrelados à palavra arbitraire, mas havia proposto retirar essa denominação infamante de decisões baseadas na lei natural por parte de um tribunal designado para esse fim, reservando a expressão arbitraire para uma autoridade sem freio, regra nem princípio. Constant, por sua vez, não discute a apropriação do conceito de arbítrio para designar as decisões extra-legais que ele propõe como modos de evitar a aplicação de leis injustas (mesmo que injustas apenas para um caso particular, sendo justas em geral), seja no caso do júri ou do direito de graça. Ao contrário do que ocorre a respeito da descrição do poder neutro nos Fragments, nem mesmo o termo, menos carregado, discrétionnaire é empregado. Não obstante, o fato de autores como Beccaria, Bentham e Sieyès utilizarem o termo arbitraire para se referir à situação imaginada por Constant (uma vontade que se

${ }^{97}$ Como vimos, o júri também pode, para Constant, tomar essa decisão moral interposta entre a lei geral e sua aplicação particular, mas esse papel do júri é negado no capítulo em que o autor discute o direito de graça, provavelmente para enfatizar a necessidade dessa instituição do indulto: "Quando vocês convocam os jurados para pronunciar sobre outra coisa que não os fatos, vocês desnaturam a função de jurado" (CONSTANT, 1980, p. 194). Podemos interpretar que o júri e o direito de graça são duas instâncias independentes em que uma decisão discricionária pode impedir a aplicação literal da lei, Constant tendo a prudência de não entrar nas duas polêmicas simultaneamente. 
coloca entre a lei e sua aplicação, tomando uma decisão que não decorre da lei ou mesmo a contraria) indica com segurança que nosso autor está novamente diante daquilo que estamos chamando "o problema do arbítrio", procurando incorporar uma dose controlada de arbítrio a seu sistema político como resposta a uma insuficiência percebida no império da lei.

A ideia de uma dose de arbítrio a ser incorporada ao sistema político como resposta a uma insuficiência percebida no império da lei é aprofundada nos Principes de politique, embora o direito de graça já seja defendido nos Fragments. Significativa, a esse respeito, é a discussão de Constant sobre onde alocar esse direito de graça ou de atenuação das penas. Nos Fragments, o autor desejava demonstrar a inconveniência de atribuir o direito de graça ao Poder Executivo e a vantagem de atribuí-lo ao poder neutro. Segundo ele, a tarefa de examinar os casos que merecem anulação ou diminuição da pena seria negligenciada em meio a outras tarefas mais urgentes dos depositários do Poder Executivo, o que levaria o direito de graça a ser exercido de modo pouco sistemático e mais arbitrário:

(...) o direito de graça, ou seja, na realidade, a parte mais decisiva dos julgamentos criminais, torna-se para eles um objeto de interesse subalterno. Eles fazem uso desse direito com indiferença e quase arbitrariamente. As penas não parecem mais ser infligidas de acordo com nenhuma regra precisa, e a vantagem mais importante das leis positivas desaparece. A vida dos culpados abandonados ao suplício é um sacrifício inútil. Todos contam ser favorecidos pela sorte, ou pelo capricho. Um escritor inglês diz, com razão, sobre esse sistema, que se trata de uma loteria de morte, na qual mil incidentes incalculáveis misturam e confundem as chances de salvação e de destruição. Não seria a mesma coisa, se o direito de graça fosse uma das atribuições do poder preservador. Esse corpo conferiria uma grande importância a essa atribuição que, de todas as suas prerrogativas, seria a mais habitual. E, se fosse ordenado que suas decisões fossem motivadas, como toda aparência de acaso desapareceria, o único inconveniente do direito de graça seria evitado, e o interesse da humanidade se conciliaria com a certeza devida à justiça (CONSTANT, 1991, p. 435-436; ênfase nossa).

O autor inglês a que Constant faz referência é, sem dúvida, Godwin. Curiosamente, nosso autor reproduz, nos Fragments, o essencial do argumento de Godwin contra o direito de graça (cf. CONSTANT, 1998b, p. 312-313). Em Enquiry Concerning Political Justice, o autor inglês havia se juntado a Beccaria, Mably, Bentham e aos demais expoentes do iluminismo penal na condenação do direito de graça, considerado como uma prerrogativa arbitrária da realeza, que decide com negligência e sem se apoiar em nenhuma regra quais condenados serão salvos e quais cumprirão sua pena. Porém, diferentemente dos demais representantes do iluminismo penal, Godwin não baseia sua condenação do direito de graça em um culto racionalista da lei. Como 
Sieyès e Constant, ele trata da impossibilidade de a lei geral se aplicar com igual justiça a todos os casos particulares (CONSTANT, 1998b, p. 312; Ibid, p. 316). Como vimos, Godwin não está entre os autores que cultuam a lei, mas antes entre os que gostariam que a lei cedesse espaço ao julgamento individual. Por isso, sua crítica do direito de graça não é, como no caso de Beccaria, Mably e Bentham, uma apologia da lei geral que se aplica, sem mediação da vontade, aos casos particulares, mas apenas uma crítica da negligência e do arbítrio com que os reis tratam os condenados, como se estes estivessem em uma loteria de morte. Ora, como podemos ver na citação acima, Constant é sensível a essa crítica de Godwin ao direito de graça. Assim, nos Fragments, nosso autor desejava que o direito de graça fosse exercido do modo menos arbitrário possível, indicando que as decisões do poder neutro a esse respeito deveriam ser motivadas, a fim de que as anulações e comutações de pena não parecessem obras do acaso e do capricho de alguns homens.

Já nos Principes de politique, o autor repete seu temor de que a atribuição do direito de graça ao Poder Executivo resulte em uma negligência dessa atribuição e em uma distribuição aleatória e injusta dos indultos, porém a concessão dessa faculdade a outro poder, pregada nos Fragments, também passa a ser vista com reserva, pela razão inversa. A razão dessa reserva é o temor de uma excessiva formalização do direito de graça, de modo a esvaziar seu caráter de decisão irredutível a qualquer regra ou princípio fixo.

\begin{abstract}
Mas outro inconveniente se apresentaria. Um poder particular, ou uma seção qualquer do Poder Judiciário, investida do direito de graça, elaboraria naturalmente regras para exercê-lo. O exercício do direito de graça se tornaria, por isso mesmo, um julgamento. Não se encontraria mais nele essa espécie de imprecisão e de latitude moral que constitui essencialmente sua justiça e sua utilidade (CONSTANT, 1980, p. 195; ênfases nossas).
\end{abstract}

Nos Principes de politique, o direito de graça se torna, assim, uma questão mais aporética do que era nos Fragments. Embora Constant enfatize a necessidade do direito de graça, ele reconhece que há inconvenientes nos dois modos de incluí-lo em uma Constituição: alocando-o no Poder Executivo, ele se torna negligenciado e desprovido de regras; atribuindo-o a outro poder ou a uma seção do Judiciário, ele se torna formalizado demais e sujeito a regras em relação às quais ele deve ser irredutível. Em certo sentido, essa aporia reconhecida por Constant é a aporia do próprio problema do arbítrio, entendido como decisão não sujeita a regras, com o potencial de contrariá-las. Afinal, o que é essa "essa espécie de imprecisão e de latitude moral" necessária para o bom 
exercício do direito de graça, se não a definição de arbítrio fornecida pelo próprio Constant em Des réactions politiques: o arbítrio como "a ausência de regras, de limites, de definições, em suma, a ausência de tudo o que é preciso" (CONSTANT, 1998a, p. 496; cf. p. 21 supra)?

Ao discutir o júri e o direito de graça nos Principes de politique, Constant encontra uma figura positiva do arbítrio (compreendido, segundo o próprio autor, como decisão tomada na ausência de regras, limites e definições precisos) no julgamento moral que indivíduos revestidos de funções específicas (jurados ou detentores do direito de graça) realizam a respeito da justiça de se aplicar uma lei geral a um caso particular, impedindo que essa aplicação se transforme em uma tirania da norma impessoal cega às circunstâncias e à contingência. Para realizar esse julgamento ético, os indivíduos em questão precisam levar em consideração aspectos morais da circunstância particular indefiníveis legalmente (CONSTANT, 1991, p. 434). Na próxima seção, veremos que esse julgamento moral sobre a justiça da lei vai muito além da função específica de jurados e detentores do direito de graça, colocando a possibilidade do arbítrio ao alcance de cada membro da comunidade política.

\subsection{Desobediência civil e sentimento religioso: 0 arbítrio ao alcance de cada indivíduo}

A faculdade que devem ter jurados e detentores do direito de graça de se opor à execução literal da lei quando a consideram injusta é apenas uma tradução institucional do princípio segundo o qual as leis não devem ser aplicadas de modo automático, sem o exame e a decisão prévios do ser humano. Se esse princípio implica, na obra de Constant, uma reformulação teórica do Poder Judiciário em relação à visão ultrarracionalista que fazia dele um simples calculador de silogismos, a revisão conceitual é ainda mais profunda no que tange aos deveres do indivíduo comum em relação à lei.

O tema é abordado no Livro XVIII dos Principes de politique ("Des devoirs des individus envers l'autorité sociale"), sendo apresentado ao público por meio do artigo “De l'obéissance à la loi", publicado em 1817 no Mercure de France (CONSTANT, 
2010, I, p. 598-608). Constant vai direto ao ponto, derivando do princípio da limitação da autoridade social que o dever de obedecer à lei tampouco pode ser ilimitado:

Como a autoridade social não existe sem limites, é evidente que os deveres dos indivíduos para com ela não são ilimitados. Esses deveres diminuem à medida que a autoridade invade a parte da existência individual que não é de sua competência. Quando essas invasões são levadas ao limite, é impossível que não resulte disso a resistência (CONSTANT, 1980, p. 475).

Constant se faz, assim, um dos pioneiros da reflexão sobre a desobediência civil, tema fundamental da teoria política dos dois séculos seguintes. ${ }^{98}$ A polêmica nesse ponto é dirigida contra filósofos cujo sistema político é baseado na disposição dos indivíduos a obedecer à lei incondicionalmente - Pascal, Bacon e, mais contemporaneamente, Bentham (CONSTANT, 1980, p. 477-480). É aqui que o afastamento de Constant em relação a Bentham se radicaliza e se torna mais significativo. Na seção anterior, foi explorada a divergência particular sobre o direito de graça, com uma consequência mais geral sobre a questão da execução literal da lei. Para compreender a disputa entre Constant e Bentham sobre o direito de desobedecer à lei, é necessário aprofundar a crítica do primeiro ao utilitarismo do segundo. Ela já é apresentada no Capítulo 7 do Livro II dos Principes de politique (“Du principe de l'utilité, substitué à l'idée de droits individuels"), no qual Constant critica a investida de Bentham "contra a ideia de direitos, e sobretudo contra a de direitos naturais, inalienáveis ou imprescritíveis" (CONSTANT, 1980, p. 59). Para o filósofo inglês, a ideia de direito natural é um princípio arbitrário derivado de um julgamento individual, sem corresponder a uma soma de bem ou de mal verificável empiricamente (BENTHAM, 1830, I, p. 12-15). O mesmo vale para a ideia de leis de natureza: "sobre leis imaginárias, cada um pode avançar o que lhe agradar, e (...) as disputas são intermináveis” (BENTHAM, 1830, I, p. 144). Quando Bentham chama os

98 A expressão "desobediência civil" é popularizada sobretudo pelo ensaio publicado por Henry David Thoreau em 1849, Resistance to Civil Government, depois rebatizado de Civil Disobedience. Embora Thoreau não cite Constant, ele adere a seu argumento sobre a superioridade da consciência moral do indivíduo em relação ao dever do súdito ou do cidadão de cumprir a lei: "Penso que devemos ser homens, em primeiro lugar, e depois súditos. Não é desejável cultivar pela lei o mesmo respeito que cultivamos pelo direito. A única obrigação que tenho o direito de assumir é a de fazer a qualquer tempo aquilo que considero direito. (...) A lei jamais tornou os homens mais justos, e, por meio de seu respeito por ela, mesmo os mais bem-intencionados transformam-se diariamente em agentes da injustiça" (THOREAU, 2007, p. 11). Para uma crítica instigante desse paradigma da desobediência civil fundado na "objeção de consciência" e na superioridade da moral do indivíduo em relação à do cidadão, ver o ensaio "Desobediência civil", de Hannah Arendt (ARENDT, 2008, p. 49-90). 
direitos naturais e as leis de natureza de princípios arbitrários, a ideia de arbítrio faz referência não apenas a um julgamento individual irredutível a qualquer verificação objetiva, mas principalmente ao fato de esse julgamento individual se colocar acima da lei estabelecida, abrindo caminho para a resistência individual à lei:

\footnotetext{
O direito real é sempre empregado em um sentido legal. O direito natural é frequentemente empregado em um sentido antilegal. Quando se diz, por exemplo, que a lei não pode ir contra o direito natural, a palavra direito é empregada em um sentido superior à lei: reconhece-se um direito que ataca a lei, que a derruba e a anula.

Nesse sentido antilegal, a palavra direito é o maior inimigo da razão e o mais terrível destruidor dos governos.

Não se pode mais argumentar com fanáticos armados de um direito natural, que cada um entende como quer, aplica como lhe convém... (BENTHAM, 1830, I, p. 147-148; ênfases do autor).
}

Para Bentham, a ideia de direito natural permite uma relação arbitrária com a lei, o único critério objetivo do que é permitido e proibido em sociedade. As leis devem ser examinadas unicamente sob o ângulo de seus efeitos em termos de maximização dos prazeres e diminuição das penas - ou seja, unicamente pelo critério da utilidade. Já para Constant, é o critério da utilidade que abre caminho para o arbítrio, pois, assim como o direito natural, "o princípio de utilidade é suscetível de um igual número de interpretações e de aplicações contraditórias" (CONSTANT, 1980, p. 59). Desse modo, tanto o critério do direito natural como o da utilidade dão margem a uma indeterminação que só pode ser resolvida pelo julgamento individual: "Em todos os sistemas, é necessário retornar ao julgamento individual" (CONSTANT, 1980, p. 523). No entanto, o déficit moral do utilitarismo abre caminho a um arbítrio mais perigoso, na medida em que o princípio da utilidade "desperta no espírito do homem a esperança de um lucro, não o sentimento de um dever. Ora, o cálculo de um lucro é arbitrário: é a imaginação que decide. Mas nem seus erros, nem seus caprichos saberiam alterar a noção do dever” (CONSTANT, 1980, p. 59).

Tanto Constant como Staël se empenham, principalmente a partir da década de 1800, em criticar o déficit moral do utilitarismo de Bentham. Para os dois autores do grupo de Coppet, a verdadeira moral só pode repousar sobre o sentimento do dever e a disposição ao sacrifício - disposições morais sufocadas pela busca exclusiva da utilidade. Em De l'Allemagne, Staël considera a nova escola de filosofia alemã inaugurada por Kant como a responsável por combater de modo vitorioso a "moral fundada sobre o interesse pessoal” (Capítulo 12 da Parte III de De l'Allemagne), a qual teria atingido seu apogeu 
na filosofia francesa do século XVIII, nos escritos de Helvétius, Diderot e Saint-Lambert (STAËL, s.d., p. 492), e no sistema filosófico de Bentham (STAËL, s.d., p. 496-497, nota 1). Constant, por sua vez, não discute tão diretamente Kant como o faz Staël, ${ }^{99}$ sua relação com o filósofo alemão sendo, desde cedo, marcada pela polêmica a respeito do dever de dizer a verdade, evocada na Introdução e no Capítulo 1 desta tese. Como veremos em seguida, a discussão do autor franco-suíço sobre a moralidade envolvida na desobediência à lei ocorre em diálogo próximo com Godwin. Entretanto, podemos estabelecer um paralelo entre o diálogo que Staël estabelece com Kant e aquele que Constant estabelece com Godwin. Tanto Kant como Godwin são mobilizados pelos autores do grupo de Coppet a fim de se contrapor ao utilitarismo de Bentham. Todavia, tanto Staël como Constant apelam ao sentimento religioso como uma maneira de se contrapor ao racionalismo moral de Kant e de Godwin. Desse modo, como veremos, o problema do arbítrio em moral é escancarado, com consequências importantes para a natureza do julgamento moral da lei a ser realizado por cada indivíduo.

Embora Staël elogie Kant por sua batalha vitoriosa contra a moral fundada sobre o interesse pessoal, ela nota que "a teoria de Kant, em moral, é severa e às vezes seca, porque ela exclui a sensibilidade" (STAËL, s.d., p. 508). Tratar-se-ia de "uma severidade que enternece" (STAËL, s.d., p. 508), na medida em que, mesmo repelindo os movimentos do coração, essa filosofia moral faria um apelo a nossa consciência, fazendo "nascer na alma algo de grande que provém ainda da sensibilidade mesma da qual ele [Kant] exige o sacrifício" (STAËL, s.d., p. 509). É devido a essa relação ambígua de Kant com a esfera do sentimento e da sensibilidade, que Staël se aproxima mais de outra vertente da filosofia alemã, formada por filósofos que, como Friedrich Heinrich Jacobi, "atribuíram ao sentimento religioso a origem da lei moral" (STAËL, s.d., p. 509). Segundo a autora, o racionalismo moral de Kant deve ser temperado por uma teoria que funda a moral sobre a emoção religiosa, porque apenas essa emoção seria forte o suficiente para vencer o impulso direcionado ao interesse pessoal e às sensações exteriores: 100 "Se a piedade não causasse emoções sublimes, quem sacrificaria os

${ }^{99}$ Ver o Capítulo VI da Parte III de De l'Allemagne, intitulado "Kant” (STAËL, s.d., p. 436-452).

${ }^{100}$ Ver os comentários de Philippe Chanial: “(...) o kantismo singular de Madame de Staël é menos ancorado nas leis da razão prática do que indissociável de uma moral sentimental, próxima dos teóricos ingleses do sentimento moral e dos românticos alemães. Seu fundamento, resolutamente anti-utilitarista, é religioso" (CHANIAL, 2001, p. 575). 
prazeres, por mais vulgares que fossem, à fria dignidade da razão? É preciso começar a história íntima do homem pela religião ou pela sensação, pois não há nada de vivo além de uma e da outra" (STAËL, s.d., p. 510). Ao fundar a moral sobre a religião, Staël acredita encontrar um equilíbrio entre o impulso do coração e o seguimento de leis fixas que nem Kant nem Jacobi teriam encontrado:

Entre essas duas classes de moralistas, aquela que, como Kant e outros ainda
mais abstratos, quer vincular todas as ações da moral a preceitos imutáveis, e
aquela que, como Jacobi, proclama que é preciso tudo abandonar à decisão do
sentimento, o cristianismo parece indicar o ponto maravilhoso em que a lei
positiva não exclui a inspiração do coração, nem essa inspiração exclui a lei
positiva (STAËL, s.d., p. 515).

Assim, a autora encontra na inspiração religiosa a possibilidade de uma moral que não é nem totalmente arbitrária, nem totalmente fixa: "nada do que provém da virtude pode ser nem totalmente arbitrário, nem totalmente fixo: assim, uma das maravilhas da religião consiste em reunir com a mesma intensidade o impulso do amor e a submissão à lei” (STAËL, s.d., p. 513). Como alguns intérpretes já ressaltaram, a valorização da religião e, mais particularmente, do cristianismo, por parte de Staël, enraíza-se em uma tradição protestante que tem como pedra angular a noção de julgamento individual, central para ela e para Constant (ROSENBLATT, 2007). O que estamos ressaltando aqui é que esse julgamento individual que a autora associa ao protestantismo não é concebido por ela como estritamente racional. Pelo contrário, esse julgamento moral reúne elementos sentimentais (compreendidos por Staël como arbitrários, por derivarem de uma decisão incomensurável do coração, e não do seguimento de normas fixas) e elementos dogmáticos, relacionados a leis religiosas positivas aceitas pela fé. Constant, como veremos, é mais crítico do que Staël em relação ao componente dogmático das leis religiosas, radicalizando a importância do sentimento religioso em detrimento das formas religiosas, de modo a tornar ainda mais agudo o componente arbitrário do julgamento moral individual.

Como já sugerido, Constant não se dedica, como Staël, a uma discussão da filosofia moral de Kant, porém é possível fazer um paralelo entre a discussão de Staël e o diálogo que o autor franco-suíço estabelece com Godwin, desde a tradução e os comentários a Enquiry Concerning Political Justice. Com efeito, Godwin é igualmente crítico do utilitarismo, vendo na busca teórica e na realização prática dos princípios universais de justiça um dever para toda consciência individual, mesmo quando o indivíduo não extrai nenhuma utilidade da realização desses princípios: “O dever de todo 
homem é consagrar suas faculdades em toda a sua extensão, para descobrir as regras da justiça e colocar em ação todas as regras descobertas" (CONSTANT, 1998b, p. 115). Na tradução que Constant realiza da obra do autor inglês, é possível perceber um interesse pelas consequências dessa crítica do utilitarismo para o questionamento do dever incondicional de obedecer às leis. Para Godwin, há uma verdadeira soberania da justiça, no sentido de que é só a ela que os indivíduos devem obediência. A própria ideia de um Poder Legislativo é questionada, pois os seres humanos não teriam o direito de legislar, apenas o de descobrir e interpretar as leis da razão e da justiça, eternas e universais (CONSTANT, 1998b, p. 129). Daí a conclusão: "quando a sociedade é injusta, ela recai ao nível do mais obscuro dos indivíduos, e todos os homens são igualmente obrigados a lhe resistir" (CONSTANT, 1998b, p. 129).

Essa conclusão de Godwin, sobre o dever que os indivíduos têm de resistir à autoridade ou às leis injustas, exerce uma influência profunda sobre Constant. É verdade que os dois autores não atribuem exatamente o mesmo sentido a palavras como "obediência" e "resistência", como nota Constant em uma nota a sua tradução de Godwin:

\footnotetext{
O autor emprega a palavra obediência em um sentido mais amplo do que o que é normalmente atribuído a ela. Ele entende por obediência o consentimento voluntário e a aprovação do julgamento, e designa por submissão, resignação e não-resistência toda espécie de obediência passiva (CONSTANT, 1998b, p. 130).
}

Desse modo, as conclusões de Constant são, nesse ponto, mais radicais do que as de Godwin. Para o autor inglês, a autoridade e as leis injustas não devem ser obedecidas no sentido de que o julgamento individual não deve lhes atribuir um consentimento voluntário e uma adesão de consciência, mas isso não impede uma "resignação" a essa autoridade ou a essas leis injustas (CONSTANT, 1998b, p. 131-133). Já Constant, distingue entre a resistência negativa, entendida como a desobediência à lei, e a resistência positiva, entendida como a oposição ativa à autoridade (CONSTANT, 1980, p. 476), mas, nos dois casos, a desobediência não é apenas um fenômeno de consciência, como em Godwin, mas uma atitude prática do indivíduo. Apesar dessa divergência, Constant é profundamente marcado pela tese de Godwin do julgamento individual como lócus de resistência às leis injustas:

Admitimos, entre os nossos princípios, que o indivíduo deve resistir a todas as injustiças exercidas pelo governo, ou pela sociedade. Resta indagar quem será o juiz da injustiça? A resposta se apresenta por si mesma: o indivíduo só pode consultar seu próprio julgamento. Qualquer outro apelo seria ilusório, pois nós não temos nenhum juiz infalível (CONSTANT, 1998b, p. 323). 
No caso de Godwin, o julgamento individual é concebido em termos racionalistas, o indivíduo devendo agir como um juiz beccariano que encontra nos princípios de justiça regras mais fixas e racionais do que as leis escritas de um país:

\begin{abstract}
Nossa consciência deve nos dirigir, sem dúvida, mas não como um tirano caprichoso que segue a impulsão cega de suas fantasias desordenadas, mas como um juiz impassível e escrupuloso, intérprete fiel da lei que ele encontra escrita. A lei de nossa consciência é a justiça (CONSTANT, 1998b, p. 129).
\end{abstract}

É aí que começa o afastamento de Constant em relação a Godwin, a respeito das bases racionais ou sentimentais do julgamento individual. Como fará sua companheira Madame de Staël em relação a Kant, o autor franco-suíço acrescenta à reflexão moral herdada de Godwin o elemento que ele acredita estar faltando: o sentimento religioso. ${ }^{101}$

Por muito tempo menosprezada pelos comentadores de Constant ou analisada separadamente de sua filosofia política, a teoria constantiana da religião ocupou o centro do pensamento do autor ao longo de toda a sua vida, tendo sua importância (inclusive para a teoria política) sido reconhecida apenas recentemente (FONTANA, 1991, Cap. 7; LEE, 2003; BINOCHE, 2007, p. 178-189; ROSENBLATT, 2008; GARSTEN, 2010; BRAHAMI, 2016, p. 182-191; entre outras referências bibliográficas recentes que estabelecem a ponte entre a teoria política de Constant e sua teoria da religião). O projeto de um livro erudito sobre a religião, tendo como linha mestra a história do politeísmo, ronda o autor desde quando ele tinha dezoito anos. Assim o escritor maduro relata o projeto que ele tinha nessa época (meados da década de 1780): “Inspirado pelos princípios da filosofia do século XVIII, e sobretudo pelas obras de Helvétius, eu tinha por único pensamento contribuir, de minha parte, para a destruição do que eu chamava de preconceitos" (CONSTANT, 2005c, p. 146). Tendo consagrado talvez a parte mais significativa de seus períodos de estudo à pesquisa sobre a história das religiões, Constant começa a publicar suas ideias sobre o assunto a partir de sua volta a Paris em 1814 (Capítulo XVII dos Principes de politique de 1815, leituras no Athénée Royal em 1818, artigo "De la religion et de la morale religieuse" publicado em La Minerve française em 1819, Quarta Parte de Commentaire sur l'ouvrage de Filangieri), culminando com a obra

${ }^{101}$ Ver os comentários de Binoche, que apontam justamente para o sentimento (religioso) como o elemento com o qual Constant complementa a crítica de Godwin ao utilitarismo, a seu ver insuficiente: “quer ele [Godwin] oponha a razão moral ao interesse egoísta ou a razão perfectível à instituição eclesiástica, ele se limita sempre a dois termos, lá onde é preciso, com toda a evidência, um terceiro: o sentimento" (BINOCHE, 2007, p. 178; ênfase do autor). 
monumental De la religion considérée dans sa source, ses formes et ses développements, publicada em três volumes entre 1824 e 1827, além de dois volumes finais sobre o politeísmo romano publicados postumamente. Ao contrário do projeto da década de 1780 , os escritos de Constant sobre a religião são marcados por uma crítica potente à filosofia do século XVIII, na medida em que procuram reabilitar o sentimento religioso como o fundamento indispensável da moral e da própria liberdade política. Ao mesmo tempo, separam o sentimento religioso das crenças dogmáticas e das instituições sacerdotais, reatando, assim, com uma crítica iluminista das religiões estabelecidas. O Livro VIII dos Principes de politique ("De la liberté religieuse") demonstra que as principais ideias sobre a religião publicadas a partir de 1814 já se encontram formuladas em 1806, informando as reflexões políticas e morais analisadas neste capítulo da tese.

O coração da teoria constantiana da religião consiste na distinção entre o sentimento religioso e as formas religiosas. Ao passo que estas são coletivas, históricas e transitórias, aquele é uma experiência individual baseada na mais natural das emoções. Constant enfatiza a irredutibilidade desse sentimento natural a todo cálculo, ou mesmo a toda forma de razão: "Esse sentimento está intimamente relacionado a todas as paixões nobres, delicadas e profundas. Como todas essas paixões, ele tem algo de misterioso. Pois a razão comum não pode explicar nenhuma dessas paixões de maneira satisfatória" (CONSTANT, 1980, p. 158). Embora inexplicáveis pelo ângulo da razão, são essas paixões, especialmente o sentimento religioso, que alçam o ser humano a uma moral elevada, pois "elas fazem o homem sair do círculo estreito de seus interesses, elas conferem à alma essa elasticidade, essa delicadeza, essa exaltação, sufocada pelo hábito da vida comum e dos cálculos que ela requer" (CONSTANT, 1980, p. 159).

É se apoiando em uma moral baseada no sentimento religioso que Constant se insurge contra a moral utilitarista, referida, no Préfacio de De la religion, como "os cálculos exatos, impassíveis, invariáveis do interesse bem entendido" (CONSTANT, 1824, p. XX). A moral utilitária condenaria os crimes, mas esvaziaria o sentido de virtudes que dispõem o ser humano ao sacrifício e à abnegação. Para Constant, essas virtudes e essa disposição ao sacrifício são necessárias para tornar o ser humano um ser moral e para garantir sua liberdade política, mas elas não poderiam ser recomendadas pelo interesse bem entendido, apenas por um sentimento religioso íntimo irredutível ao cálculo racional: 
Não, a natureza não colocou nosso guia em nosso interesse bem entendido, mas em nosso sentimento íntimo. Esse sentimento nos adverte sobre o que é mau ou sobre o que é bom. O interesse bem entendido só nos faz conhecer o que é vantajoso ou o que é prejudicial (CONSTANT, 1824, p. XXVI-XXVII).

Ao situar a fonte do dever moral em um sentimento religioso íntimo, Constant realiza um movimento análogo ao que realizava, no mesmo momento, sua companheira Madame de Staël. Não obstante, como já sugerido, a aversão de Constant aos dogmas religiosos positivos o leva a radicalizar a importância do componente puramente sentimental e individual da religião, ao passo que Staël via na religião a possibilidade de reunir, no julgamento moral, o impulso do coração e a obediência a leis positivas. Assim, Constant vai ainda mais longe do que Staël na afirmação de uma superioridade do sentimento em relação à razão ${ }^{102}$ e na reivindicação de uma moral não definida por princípios rígidos, mas por um sentimento repleto "de impressões vagas e de emoções confusas, (...) inexplicáveis pelo rigor do raciocínio" (CONSTANT, 1980, p. 159). Enquanto Staël propõe um julgamento moral que não seja nem totalmente arbitrário, nem totalmente fixo (STAËL, s.d., p. 513; cf. p. 196 supra), Constant assume com toda a força o arbítrio inerente ao julgamento moral individual, em oposição ao racionalismo moral de Kant e Godwin e ao cálculo de utilidade de Bentham. Nenhum desses três autores hesitaria, aliás, em qualificar o julgamento baseado no sentimento religioso, defendido por Constant, de arbitrário.

Após esse parêntese sobre os fundamentos morais da crítica de Constant ao utilitarismo, podemos compreender melhor por que Bentham é o alvo privilegiado na discussão do Livro XVIII dos Principes de politique sobre o direito de desobedecer à lei. O utilitarista é alvejado na qualidade de precursor do positivismo jurídico, ${ }^{103}$ o qual, devido à recusa do direito natural, viu na lei a criação dos direitos e dos delitos, ${ }^{104}$

${ }^{102}$ Para Frédéric Brahami, Constant se une a seu principal inimigo, Burke, na consideração de que “uma barbárie racional é não somente pensável, mas inevitável quando o sentimento religioso é sufocado" (BRAHAMI, 2016, p. 186) - a possibilidade de uma barbárie fundada na razão sendo uma lição da Revolução Francesa compartilhada por contrarrevolucionários, liberais e progressistas no século XIX. O dualismo instaurado por Constant "entre a pureza do afeto e a impureza do conhecer" "é uma das fontes profundas do 'espiritual republicano' que vai forjar a alma francesa na sequência do século XIX" (BRAHAMI, 2016, p. 190).

${ }^{103}$ Para o sentido da utilização dessa expressão em relação a Bentham, ver HALPÉRIN, 2008.

104 “A lei cria um delito, seja por uma ordem positiva ou por uma proibição" (BENTHAM, 1830, I, p. 164). 
rejeitando qualquer motivo legítimo para desobedecer à lei. Essa postura choca a modalidade particular de liberalismo de Constant, preocupada, como vimos, com o julgamento moral realizado pelo sentimento íntimo de cada indivíduo. Segundo o autor, um sujeito moral não pode simplesmente se contentar com a definição de crime estipulada pela lei. O dever de obedecer à lei supõe a pesquisa anterior, por parte de cada indivíduo, da fonte e do conteúdo da ordem apresentada pela autoridade como uma lei. Se aquilo que se apresenta como lei não parte de uma fonte legítima ou legisla sobre alguma esfera da vida humana sobre a qual o indivíduo deve ter autonomia, a lei em questão não deve ser obedecida. O mesmo vale para leis retroativas, contrárias à moral ou que dividem os cidadãos em classes, punindo-os por ações que não dependem deles como indivíduos (CONSTANT, 1980, p. 482-483).

Ao passo que as considerações relativas à fonte e ao escopo da lei, assim como a sua não retroatividade e sua aplicação a ações em vez de indivíduos, balizam-se por critérios minimamente objetivos, evocados nas seções anteriores deste capítulo, é na desobediência às leis contrárias à moral que o problema do arbítrio se torna mais agudo na discussão de Constant sobre o julgamento individual das leis. É verdade que o autor não prega que a desobediência civil se baseie em um mero capricho individual, fundamentando-a em um julgamento ético segundo leis da moral e direitos naturais superiores à lei positiva. Entretanto, Constant coloca em evidência o caráter vago e indeterminado dessas leis da moral e desses direitos de natureza que devem orientar o julgamento ético do indivíduo. Ao contrário das teorias da lei natural do século XVII, ele não considera as leis de natureza como preceitos deduzíveis e enunciáveis por qualquer um que recorra à razão. Se o autor franco-suíço afirma, contra Bentham, o critério da lei de natureza - "Querer fazer inteiramente abstração da natureza, em um sistema de legislação, é retirar das leis ao mesmo tempo sua sanção, sua base e seu limite" (CONSTANT, 1980, p. 480) -, não é por ver nela um padrão de objetividade, mas apenas porque ela evoca um sentimento moral ausente na referência à lei positiva ou à utilidade:

A palavra de lei é tão vaga quanto a de natureza. (...). Se fosse preciso escolher
entre as duas, a de natureza desperta, ao menos, uma ideia mais ou menos igual
em todos os homens. A de lei pode se aplicar às ideias mais opostas. Quando
nos ordenaram o assassinato, a delação, a espionagem, isso não nos foi
ordenado em nome da natureza; todo mundo teria sentido que havia
contradição nos termos; isso nos foi ordenado em nome da lei, e não houve
mais contradição (CONSTANT, 1980, p. 480).

Desse modo, a lei de natureza desperta um sentimento moral eclipsado pelo utilitarismo e pelo positivismo jurídico de Bentham. Mas a base moral do julgamento 
individual pregado por Constant continua sendo o sentimento íntimo, em sintonia com sua teoria da religião exposta acima. Como esse sentimento íntimo não é orientado por regras precisas, o julgamento moral constantiano reencontra a figura do arbítrio, não apenas de acordo com a definição de Bentham e do iluminismo penal, para quem o julgamento arbitrário é aquele que decorre do sentimento e não de critérios objetivos, mas também de acordo com a definição de arbítrio do próprio Constant, já evocada neste capítulo: o arbítrio como "a ausência de regras, de limites, de definições, em suma, a ausência de tudo o que é preciso" (CONSTANT, 1998a, p. 496). Ao discutir a desobediência civil, o autor reencontra "essa espécie de imprecisão e de latitude moral" necessária para o bom exercício do direito de graça (cf. p. 191 supra). Porém, essa faculdade de decisão discricionária é agora colocada ao alcance de cada indivíduo, extrapolando as atribuições de instituições específicas.

Para Lucien Jaume, um dos intérpretes que mais se interessaram pela apreciação individual das leis pregada por Constant e por sua crítica a Bentham, ${ }^{105}$ "o sujeito liberal apto a julgar sobre o valor das leis não é a subjetividade sem regras" (JAUME, 1997, p. 93. Nossa ênfase, no entanto, reside justamente na ausência de regras precisas a orientar o julgamento ético do sujeito liberal de Constant, dada a insistência do autor no fundamento sentimental desse julgamento e no caráter vago e indefinível desse sentimento moral. $\mathrm{O}$ autor tem consciência de estar se movendo em um terreno difícil, no qual a oposição republicana clássica entre lei e arbítrio, abraçada até então, tem pouco a dizer. Não se trata mais apenas de limitar o arbítrio dos governantes por meio de leis escritas, mas de limitar o potencial tirânico das próprias leis. Porém, esta última limitação, pela própria natureza do objeto a ser limitado, não pode ser sujeita a normas fixas:

\footnotetext{
A autoridade do governo pode ser limitada de maneira precisa, porque a lei pode a limitar. A limitação está fora. É fácil ver se ela é transgredida; mas não é o mesmo com a competência da lei. Como a lei é a única regra escrita que pode existir, é muito menos evidente dizer o que nela constitui a transgressão (CONSTANT, 1980, p. 477).
}

Não há direito mais individualizado do que o de desobediência à lei. "Resistir é um direito positivo, individual, imprescritível, que só é subordinado às considerações resultantes da utilidade, da chance do sucesso, do perigo do abalo e da comparação do mal que ele pode causar com o mal que se quer prevenir" (CONSTANT, 1980, p. 627).

105 Outros comentários sobre a crítica de Constant a Bentham podem ser encontrados em: HOLMES, 1984, p. 125-127; FONTANA, 1991, p. 23-24 e 114-117; LEE, 2003, p. 160-171. 
Ao contrário do direito de revolução, que só existe quando a revolução em questão "é conforme ao sentimento universal"106 (CONSTANT, 1980, p. 629), o direito de resistência à lei opressora não pode ser submetido a nenhum tribunal exterior à consciência individual. Além do sentimento íntimo do indivíduo, há nessa questão toda uma avaliação das circunstâncias e da contingência que impede o direito de resistência de ser enquadrado por máximas precisas, lembrando o raciocínio do autor sobre o direito de graça:

Enfim, pode-se estabelecer seriamente que a resistência é sempre ilegítima? Pode-se declará-la culpável sob Nero, sob Vitélio, sob Caracala? Acredita-se contornar as dificuldades por máximas abstratas e gerais que parecem deixar o julgamento pessoal fora da questão. Mas as circunstâncias, que se complicam e se nuançam, tornam essas máximas inúteis e estéreis na aplicação (CONSTANT, 1980, p. 476).

A primazia do sentimento íntimo de natureza religiosa e a necessidade de considerar as circunstâncias e a contingência evidenciam a insuficiência do império da lei defendido em termos absolutos nos Livros V e VI dos Principes de politique. Embora o autor continue se opondo firmemente às violações da lei em nome da salvação pública, ele percebe que o indivíduo só será livre, e a soberania só será limitada, se o cidadão puder contrariar a lei com base em sentimentos morais irredutíveis a regras precisas. Se, nos Fragments, o arbítrio havia sido concentrado em um poder de Estado específico (o poder neutro), tendo por missão salvar a República de crises insolúveis pelo simples apelo à lei (ver o Capítulo 2 da tese), nos Principes de politique, o arbítrio é posto ao alcance de cada cidadão e recebe por paradigma um julgamento moral orientado por um sentimento íntimo de fundo religioso.

Nos Fragments, o artifício retórico para desvincular da palavra arbitraire sua associação recorrente com a tirania é substituí-la pelo termo mais neutro discrétionnaire. Nos Principes de politique, Constant não utiliza a palavra arbitraire nem discrétionnaire para se referir aos casos em que um agente político (os jurados, os detentores do direito de graça ou os cidadãos comuns) pode contornar ou mesmo contrariar a lei. Não obstante, como procuramos mostrar ao longo do capítulo, essa decisão não sujeita a normas fixas se enquadra na definição de arbítrio não apenas do próprio Constant, mas do senso comum

${ }^{106}$ Para Constant, a revolução é um fenômeno histórico ligado ao progresso desigual das ideias e das instituições de um povo, tendo por objetivo restaurar o acordo entre ideias e instituições, como teorizado em Des réactions politiques (ver o Capítulo 1 da tese). Portanto, ela pertence a um universo heterogêneo em relação ao direito individual de resistência. 
filosófico dos séculos XVIII e XIX (Beccaria, Sieyès, Bentham etc.). Assim, nos Principes de politique, a necessária incorporação do arbítrio ao sistema político, percebida desde os Fragments, não ocorre mais pela via da concentração, mas da disseminação pelo corpo constitucional, de modo a pô-lo ao alcance de cada indivíduo. Paralelamente, o arbítrio é moralizado, na medida em que seu paradigma agora é o julgamento moral, embora não pautado por regras precisas.

\subsection{A liberdade dos modernos em perspectiva histórica}

Nesta última seção do capítulo, o objetivo é compreender o papel do arbítrio no novo ponto de vista teórico apresentado por Constant no Livro XVI dos Principes de politique ("De l'autorité sociale chez les anciens"). Esse novo ponto de vista teórico pode ser chamado, grosso modo, de perspectiva da relativização histórica. Manent (2012, p. 184) já apontou que Constant, e o liberalismo pós-revolucionário de modo geral, deslocam-se entre duas autoridades desiguais: a História e a natureza. Ora, especificamente nos Principes de politique, Constant evita, em geral, uma abordagem historicista, tratando os princípios de liberdade como universais, imutáveis e atemporais. Essa perspectiva universalista é rompida justamente no Livro XVI, quando, aproximando-se do fim da obra, o autor se propõe a

\footnotetext{
(...) resolver uma dificuldade que talvez já tenha se abatido sobre o espírito de mais de um de meus leitores. Os princípios que eu apresento como a base de toda liberdade possível atualmente são diretamente opostos aos princípios adotados outrora pela organização política da maior parte das nações livres da Antiguidade. (...) São, entretanto, os antigos que nos oferecem os mais nobres exemplos de liberdade política que a História nos transmite. Encontramos neles o modelo de todas as virtudes que o gozo dessa liberdade produz e que são necessárias para que ela subsista (CONSTANT, 1980, p. 419).
}

É assim que Constant começa a sistematizar pela primeira vez um dos temas que mais o consagrarão: a comparação entre a liberdade dos antigos e a dos modernos. Sua inspiração mais direta é provavelmente o Capítulo 3 ("De l'opinion publique") da Primeira Parte de Des circonstances actuelles de Staël, cuja escrita ele acompanhou de perto. Nem o livro de Staël nem os Principes de politique foram publicados durante a vida dos autores, mas a comparação entre a liberdade dos antigos e a dos modernos, acompanhada da famosa crítica segundo a qual os revolucionários franceses teriam tentado impor anacronicamente a liberdade antiga a uma nação moderna, foi publicada 
nos capítulos VI a IX da Segunda Parte de De l'esprit de conquête et de l'usurpation, de 1814, e principalmente na célebre conferência de 1819, "Da liberdade dos antigos comparada à dos modernos", uma das sessões de um curso de Constant sobre a constituição inglesa proferido no Athénée royal de Paris.

O tópos da liberdade dos antigos comparada à dos modernos na obra de Constant já recebeu interpretações bastante variadas, confundindo-se em parte com a história da recepção crítica do próprio autor. Como já vimos na Introdução, na segunda metade do século XX, a conferência de 1819 passou a ser lida na chave do ensaio "Dois conceitos de liberdade" de Isaiah Berlin, de 1958, e Constant e Berlin passaram a ser interpretados como defensores da liberdade negativa contra a positiva, da independência individual e da ausência de interferência contra a participação política e o autogoverno. Ora, desde as últimas décadas do século XX, essa leitura de Constant é contestada pela bibliografia especializada, a qual enfatiza os alertas do autor franco-suíço contra o enfraquecimento da participação política, considerado por ele como a principal ameaça à liberdade dos modernos. Assim, seu objetivo não era estabelecer uma oposição absoluta entre a liberdade dos antigos e a dos modernos, a qual excluiria a primeira, mas alertar para a necessidade de combinar as duas formas de liberdade no contexto do governo representativo.

Nesta seção do capítulo, o objetivo é compreender de que modo a contraposição entre a liberdade dos antigos e a dos modernos opera uma relativização histórica dos princípios de liberdade expostos ao longo dos Principes de politique, especialmente aquele que proíbe todo tratamento arbitrário do indivíduo por parte da autoridade política. Esses princípios de liberdade são relativizados historicamente na medida em que, pela primeira vez nos Principes de politique, Constant não os deriva de direitos atemporais do indivíduo, mas de uma configuração histórica particular, diferente da dos povos antigos. Alterando seu ângulo de análise, o autor não trata mais os princípios de liberdade liberais como universais, mas como próprios de uma sociedade comercial moderna constituída na escala do Estado-nação. Admite-se que os povos antigos podiam ser livres segundo princípios de liberdade diferentes, mais adequados a sua forma específica de organização social.

É verdade que Constant não é um relativista completo, já que seu modo progressista de conceber a História, herdado do Iluminismo, tende a ver os modernos como mais evoluídos do que os antigos. Especialmente, a substituição da guerra e da 
escravidão pelo comércio como força econômica motriz e a aquisição da noção de direitos individuais são consideradas pelo autor como progressos morais inestimáveis. Essa visão progressista da História costuma ser enfatizada pelos intérpretes que aproximam Constant de Berlin, vendo em ambos uma rejeição completa da liberdade dos antigos, ou da liberdade positiva. Por outro lado, mesmo com sua visão progressista da História, a admiração de Constant pelos povos antigos é patente, apesar de sua crítica aos que consideram possível tomá-los como modelo de imitação. Na citação acima, os antigos são referidos como "os mais nobres exemplos de liberdade política que a História nos transmite" (CONSTANT, 1980, p. 419), exibindo do modo mais exemplar as virtudes necessárias para conservar a liberdade. Em outras palavras, o autor podia considerar os antigos como impróprios para vivenciar a liberdade moderna, mas ele jamais ousaria dizer que eles não eram livres, mesmo que a seu modo. Em alguns momentos, como em De la religion, Constant expõe aspectos em que o ethos antigo era superior ao moderno, tendo forjado uma fusão perfeita entre religião, moral e política que os modernos seriam incapazes de alcançar (FONTANA, 1991, p. 108-111). Embora desconhecedores da liberdade civil, os antigos eram mais capazes de conservar a liberdade política do que os modernos, cuja imersão na vida privada e na busca de interesses particulares, negligenciando as virtudes caras aos antigos e fundamentais para a conservação da liberdade, é incansavelmente criticada pelo autor.

Apesar dessa admiração pelos povos antigos e por sua vigorosa virtude, um dos aspectos da cidade antiga mais criticados por Constant é a ausência de proteção do indivíduo em relação a um tratamento arbitrário por parte das autoridades. Esse tratamento arbitrário é associado pelo autor a instituições "morais" dos antigos, como a censura e o ostracismo:

Todas as instituições morais dos antigos se tornaram inaplicáveis a nós. Chamo instituições morais, por oposição às instituições puramente políticas, aquelas que, como a censura ou o ostracismo, atribuíam à sociedade ou a um número qualquer de homens uma jurisdição discricionária, a qual se exercia não de acordo com formas legais e judiciárias, mas segundo a ideia vagamente concebida da moralidade de certos indivíduos, de suas intenções e do perigo que eles podiam representar para o Estado (CONSTANT, 1980, p. 435; ênfase nossa). ${ }^{107}$

107 Ressaltamos o uso de discrétionnaire como sinônimo de arbitraire, um ponto importante ressaltado no Capítulo 2 desta tese. 
A discussão sobre os antigos traz, assim, Constant novamente ao tema da condenação das medidas arbitrárias, em sintonia com os Livros V e VI dos Principes de politique. Todavia, ao passo que esses livros condenavam as medidas arbitrárias universalmente, criticando inclusive os antigos quando eles recorreram a medidas de polícia e golpes de Estado, no Livro XVI, o arbítrio se torna admissível no contexto específico da cidade antiga, onde imperava uma compreensão da liberdade em que "o interesse público vinha antes da segurança e da liberdade individual" (CONSTANT, 1980, p. 435). O arbítrio não é mais deslocado em qualquer contexto, mas apenas no moderno, em cuja compreensão de liberdade "a segurança e a liberdade individual vêm antes do interesse público" (CONSTANT, 1980, p. 435).

Aprofundando suas reflexões sobre a censura romana, Constant a considera como uma instituição arbitrária, no sentido pejorativo do termo, mas esse arbítrio é relativizado historicamente, quando o autor sugere que o arbítrio era contrabalançado pela simplicidade dos costumes antigos e pelo tamanho reduzido de Roma em seus primeiros tempos, o que colocava o censor sob um controle maior por parte do cidadão comum:

\begin{abstract}
Muito se elogiou o efeito moral da censura romana. Mas os censores tinham um poder legal e infligiam penas positivas. $\mathrm{Na}$ verdade, eles as infligiam arbitrariamente. Mas esse arbítrio era contrabalançado pela simplicidade dos costumes antigos e pela possibilidade possuída por cada cidadão, espectador quase imediato de todas as ações de seus iguais, de apreciar a equidade dos censores (CONSTANT, 1980, p. 442).
\end{abstract}

Com essas considerações, a condenação categórica do arbítrio realizada nos Livros V e VI dos Principes de politique é novamente relativizada, dessa vez em uma perspectiva histórica. Se Constant escreve que, “em um Estado como a França, o poder dos censores seria uma tirania intolerável” (CONSTANT, 1980, p. 443), não é mais porque o arbítrio é um mal universalmente, mas porque ele produz tirania em um país grande, moderno e complexo como a França. O autor chega a relacionar a perda de eficácia da censura à corrupção dos costumes romanos, fazendo referência a Montesquieu:

A censura degenerou mesmo em Roma, quando a extensão da República, a
complicação das relações sociais e os refinamentos da civilização haviam
retirado dessa instituição aquilo que lhe servia ao mesmo tempo de base e de
limite. Não era a censura que havia criado os bons costumes; era a simplicidade
dos costumes que constituía o poder e a eficácia da censura (CONSTANT,
1980, p. 443).

Em nota após esse trecho, Constant remete ao Capítulo XXI do Livro XXIII de $O$ espírito das leis, no qual Montesquieu escreve: “A corrupção dos costumes destruiu a 
censura, estabelecida para destruir a corrupção dos costumes; mas, quando a corrupção se tornou geral, a censura não teve mais força" (MONTESQUIEU, 2005, p. 448). No limite, é a corrupção dos costumes que torna o arbítrio perigoso, na medida em que impede os cidadãos de vigiar a atividade discricionária dos censores. Assim, é a grande extensão dos Estados modernos e a impossibilidade de manter todo o povo reunido em uma única cidade vigiando os magistrados constantemente que tornam as instituições discricionárias perigosas no contexto moderno. Além disso, é o fato de que os antigos colocavam o interesse público antes da segurança e da liberdade individuais, ao passo que os modernos colocam a segurança e a liberdade individuais antes do interesse público. Esse modo relativista de colocar o problema do arbítrio abre uma margem para a justificação de medidas arbitrárias quando, em situações de urgência, o interesse público parece reclamar uma prioridade sobre a segurança e a liberdade individuais, mesmo em um contexto moderno. Como vimos no Capítulo 2, Constant entende resolver essa questão pensando, no contexto moderno, um poder autorizado a agir discricionariamente sobre os outros poderes, mas não sobre os indivíduos. O poder neutro se torna o "censor" apropriado para as sociedades modernas, uma vez que sua atuação discricionária sobre o sistema político não põe em risco a liberdade e a segurança individuais. ${ }^{108}$

Além dessa alocação do arbítrio no poder neutro, o autor dedica boa parte dos Principes de politique construindo a legitimidade de o próprio indivíduo tomar decisões discricionárias que não decorrem da lei, ou mesmo a contrariam, como vimos nas últimas seções deste capítulo. A tentativa de suprimir esse arbítrio deixado a cargo do indivíduo é justamente uma das críticas centrais de Constant aos "imitadores modernos das repúblicas da Antiguidade" (Capítulo 8 do Livro XVI dos Principes de politique, Capítulo 7 da Segunda Parte de De l'esprit de conquête et de l'usurpation). Os principais "imitadores modernos das repúblicas da Antiguidade" no século XVIII francês seriam Rousseau e o abade de Mably, considerados por Constant como as maiores influências intelectuais negativas da Revolução Francesa. É verdade que a crítica de Constant a Rousseau é mais nuançada, pois o autor dos Principes de politique admite que o problema esteve muito mais nas apropriações do filósofo genebrino durante a Revolução Francesa do que na obra do autor d'O contrato social em si (CONSTANT, 1980, p. 618-619). O

108 Vale lembrar que, na busca por um poder capaz de regular a interação entre o Legislativo e o Executivo, outros autores, no contexto da Revolução Francesa, haviam proposto um terceiro poder inspirado na censura romana (GAUCHET, 1995). 
principal objeto de crítica de Constant, no capítulo referente aos "imitadores modernos das repúblicas da Antiguidade", é Mably, cujo livro De la législation, ou Principes des lois, de 1776, é referido como "o código de despotismo mais completo que se possa imaginar" (CONSTANT, 1980, p. 450). É bastante controverso até que ponto a leitura que Constant faz de Mably é justa. Em muitos aspectos, essa leitura é enviesada, já que Mably é retratado como um inimigo inconciliável da liberdade individual disposto a sacrificar completamente o interesse particular pelo interesse público, o que é contradito em passagens importantes do autor (cf. MABLY, 1792, p. 267-270). Entretanto, o que nos interessa é a divergência que ocorre entre Mably e Constant em relação ao próprio uso do termo arbitraire. Embora o uso predominante do termo, por parte de Mably, refirase a "poder arbitrário", "governo arbitrário" ou "monarquia arbitrária" (MABLY, 1792, p. 134, 138, 146, 187, 191, 258, 285), no sentido de governo absoluto e acima das leis, há passagens em que o autor utiliza a palavra arbitraire para se referir a liberdades individuais caras a Constant, como a disposição da propriedade e a educação das crianças: “(...) é impossível julgar de modo exato os males produzidos pelas leis que permitem aos pais repartir desigualmente entre seus filhos e deixam a cada cidadão a liberdade de dissipar seus bens ou dispor deles arbitrariamente" (MABLY, 1792, p. 118; ênfase nossa); “(...) a república nunca formará cidadãos excelentes enquanto a educação não for pública e geral. Vocês permitirão que os pais de família façam arbitrariamente regras para si a esse respeito?” (MABLY, 1792, p. 309; ênfase nossa).

Constant cita a proibição da livre disposição da propriedade (interdição da venda, alienação de bens e testamentos) e de toda educação particular como exemplos da tendência de Mably a, com base nos exemplos antigos, suprimir a liberdade individual (CONSTANT, 1980, p. 450-452). O direito de propriedade e o de educar livremente os filhos não estão entre as liberdades individuais fundamentais postuladas por Constant no Capítulo 6 do Livro II dos Principes de politique (liberdade de religião, de expressão e de não ser tratado arbitrariamente pelo Estado), mas são casos em que o autor aplica sua máxima de restrição da atividade governamental em nome de uma maior autonomia dos indivíduos. Nos dois casos, como não estão em jogo liberdades individuais fundamentais, não se trata de se opor a qualquer espécie de regulação, mas apenas de limitar a capacidade de intervenção do Estado, a fim de assegurar ao indivíduo o máximo de direitos possível sem prejudicar a sociedade. Sobre a propriedade, eis a máxima advogada por Constant: 
A propriedade, em sua qualidade de convenção social, é da competência e sob a jurisdição da sociedade. A sociedade possui sobre ela direitos que ela não tem sobre a liberdade, a vida e as opiniões de seus membros.

Mas a propriedade se liga intimamente a outras partes da existência humana, entre as quais umas não se submetem de modo algum à jurisdição coletiva, e outras só se submetem a essa jurisdição de maneira limitada. Consequentemente, a sociedade deve restringir sua jurisdição sobre a propriedade, porque ela não poderia exercer essa jurisdição em toda a sua extensão, sem atentar contra objetos que não lhe são subordinados (CONSTANT, 1980, p. 233).

Assim, o autor admite que a sociedade deve exercer alguma espécie de regulação sobre a propriedade, pois ela é uma convenção social e não um direito natural, mas sua preocupação é que essa regulação estatal não limite a faculdade do indivíduo de fazer escolhas autônomas a respeito de sua vida e de sua esfera familiar. O direito de escrever testamentos, combatido por Mably, é para Constant uma espécie de exercício moral do pai de família, por meio do qual o poder paternal, essencialmente arbitrário, modera-se ao se tornar natural e moral: “O poder paternal é necessariamente arbitrário. Tal poder é bom, quando existe pela natureza. Ele seria funesto, se existisse pela lei” (CONSTANT, 1980, p. 562-563; ênfase nossa). A crítica do autor é dirigida aos "legisladores de muitos povos livres" que,

(...) considerando, por um lado, a disseminação das propriedades como favorável à liberdade e, por outro lado, o poder paternal como necessário à moral, fizeram, consequentemente, leis para colocar obstáculos à acumulação das propriedades e tentaram mil instituições para justificar o poder paternal (CONSTANT, 1980, p. 239).

Para Constant, a lei não deve forçar a disseminação das propriedades, pois sua tendência natural já seria se disseminar com a simples abolição das leis aristocráticas que levam a sua concentração, especialmente o direito de herança exclusiva do primogênito (CONSTANT, 1980, p. 238), e as leis não deveriam tampouco tentar fortalecer o poder paternal. O direito de escrever testamentos, combatido tanto pela direita contrarrevolucionária partidária do direito do primogênito e da concentração forçada das terras quanto pela esquerda republicana ou proto-socialista partidária da disseminação forçada das propriedades, é visto pelo autor como um modo de resguardar um arbítrio salutar ao pai de família, o qual tende a se moralizar por seu próprio uso.

O raciocínio é semelhante no que diz respeito à educação. Como no caso da propriedade, Constant não nega que a educação seja um assunto de competência social, mas argumenta que a supressão de toda margem de decisão dos indivíduos a esse respeito é uma ameaça a sua liberdade. Como transmissão dos conhecimentos adquiridos às novas 
gerações, a educação "é inteiramente da competência do governo" (CONSTANT, 1980, p. 370). Seu medo é que os governos mobilizem e deturpem a educação, tornando-a um "meio de se apoderar da opinião dos homens, a fim de formá-los para a adoção de certa quantidade de ideias religiosas, morais, filosóficas ou políticas" (CONSTANT, 1980, p. 370). Embora o autor considere a educação pública como a mais propícia para a formação de cidadãos virtuosos, ele prega que,

(...) se o sistema de educação favorecido pelo governo for ou parecer vicioso para alguns indivíduos, eles possam procurar um asilo na educação particular, ou em institutos sem relação com o governo. A sociedade deve respeitar os direitos individuais, e são compreendidos nesses direitos os dos pais sobre seus filhos (CONSTANT, 1980, p. 375).

Portanto, em dois casos em que Mably condena direitos individuais como arbitrários (a livre disposição da propriedade e o direito de educar os filhos segundo regras próprias), Constant defende essa margem de decisão discricionária concedida ao indivíduo, com o argumento de que esse arbítrio, mesmo não pertencendo às liberdades individuais fundamentais, é importante para a formação de um julgamento moral autônomo por parte do indivíduo. Como no caso da desobediência civil, poderes individuais discricionários que outros autores condenam pelo rótulo arbitraire são incorporados na teoria política de Constant e compreendidos pelo paradigma do julgamento moral individual.

É significativa, a esse respeito, a divergência de Constant em relação a Godwin sobre a noção de direitos do homem ou do indivíduo. O autor inglês chega a se referir aos direitos do homem como "doutrina dos poderes ou dos direitos discricionários" (CONSTANT, 1998b, p. 282), negando que o indivíduo tenha o poder discricionário de decidir o que quer que seja. Para ele, toda a organização política deve decorrer da consciência individual, mas essa consciência é pensada sob a forma de um julgamento moral que impõe deveres, não direitos:

Diz-se comumente que nós temos o direito de dispor de nossa fortuna, o direito de empregar nosso tempo, o direito de escolher nossas ocupações. Mas essa asserção só é admissível se for provado que nenhum dever restringe, para esses objetos, a liberdade de nossa conduta (CONSTANT, 1998b, p. 105).

Segundo Godwin, a doutrina dos direitos do homem é imoral, pois confere a cada indivíduo o poder de decidir discricionariamente sobre suas ações, liberando-o do dever de ajudar seus semelhantes. Embora o autor inglês tenha a preocupação de limitar a esfera de atuação legítima da autoridade política, ele é categórico em afirmar que o que limita a esfera de atuação legítima do governo não são os direitos do indivíduo, mas a falibilidade 
intrínseca do próprio governo, a qual ameaça os progressos das luzes. Um exemplo desse raciocínio é o modo como Godwin concebe a liberdade de imprensa: não como um direito de o indivíduo publicar aquilo que ele tem vontade de expressar, pois o dever moral obriga a expressar apenas a verdade, mas como um reconhecimento de que a intervenção da autoridade sobre as opiniões é nociva ao progresso das luzes, já que o governo não é um juiz infalível. Na versão original em inglês, o raciocínio é bastante cristalino:

\begin{abstract}
A liberdade política de consciência e de imprensa, longe de ser, como se supõe comumente, uma extensão, é um novo caso de limitação dos direitos e do poder discricionário. A consciência e a imprensa devem ser livres de restrições, não porque os homens tenham o direito de se desviar da linha exata prescrita pelo dever, mas porque a sociedade, o agregado de indivíduos, não tem o direito de assumir a prerrogativa de um juiz infalível, nem o de se encarregar autoritariamente de ordenar a seus membros em matérias de pura especulação (CONSTANT, 1998b, p. 435).
\end{abstract}

Basta examinar as notas de Constant na tradução do capítulo de Godwin referente aos direitos do homem para perceber seu incômodo com a rejeição do autor inglês ao caráter discricionário intrínseco aos direitos individuais. Para o autor franco-suíço, a limitação da autoridade política não poderia ser pensada senão sob a égide dos direitos individuais. Sobre a oposição radical entre direitos e deveres estabelecida por Godwin, Constant escreve: "o autor negligenciou de distinguir, na palavra direito, o que nós temos nós mesmos o direito de fazer e o que nós temos o direito de exigir dos outros" (CONSTANT, 1998b, p. 104; ênfase do autor). Sobre o argumento de Godwin segundo o qual a restrição dos direitos do governo ou da sociedade não cria um direito discricionário para o indivíduo, ele escreve: “O que a sociedade não tem o direito de fazer em relação ao indivíduo, este indivíduo tem o direito de exigir que a sociedade não faça. Em todos esses raciocínios, há inexatidão da expressão" (CONSTANT, 1998b, p. 106).

Em suma, embora tanto Mably como Godwin tenham criticado o caráter arbitrário ou discricionário dos direitos individuais, Constant considera primordial preservar essa dose de arbítrio conferida ao indivíduo. Longe de opor a irracionalidade do arbítrio à racionalidade do julgamento moral, como faz Godwin, Constant procura fazer do direito de decisão discricionária a condição do aprendizado moral do indivíduo, pensando o arbítrio individual pelo paradigma do julgamento moral.

Que lugar esse arbítrio compreendido pelo paradigma do julgamento moral individual pode ter na teoria constitucional de Constant, reformulada a partir de 1814 ? Esta será a questão do próximo capítulo. 


\section{Capítulo 4: A disseminação do arbítrio na monarquia constitucional}

As derrotas de Napoleão para a Sexta Coalizão, a partir de 1812, reacendem para Constant a esperança de desempenhar um papel político de destaque na França - uma esperança que parecia enterrada desde sua expulsão do Tribunato, em 1802. No contexto de esfacelamento do Império napoleônico, o autor escreve e publica, em janeiro de 1814, De l'esprit de conquête et de l'usurpation dans leurs rapports avec la civilisation européenne, marcando na opinião pública suas credenciais antibonapartistas. Em 15 de abril de 1814, poucos dias após a abdicação do Imperador, Constant retorna a Paris, em seguida às tropas do Príncipe Real da Suécia, Bernadotte, de cujos projetos de assumir o trono da França como rei liberal ele havia participado nos últimos meses - negando, em artigo de 18 abril ao Journal des Débats, ser um secretário íntimo de Bernadotte. Em “Des Révolutions de 1660 et de 1688 en Angleterre, et de celle de 1814 en France”, artigo publicado em 21 de abril de 1814, o autor apoia oficialmente a Restauração Bourbon sobre bases constitucionais, o regime já anunciado em 6 de abril, quando o Senado Conservador havia proclamado uma Constituição monárquica (chamada de Constituição senatorial) e convocado o irmão mais velho de Luís XVI a assumir o trono francês. É a ocasião para Constant, até então conhecido pela defesa incondicional da República durante o Diretório, declarar sua lealdade ao novo regime que se anunciava (a condição prévia para poder voltar a participar da política francesa), pintando a Constituição senatorial como o arranjo que poderia unir, enfim, monarquistas, revolucionários de 1789 e republicanos: "O que queriam, afinal, os republicanos? As mesmas coisas sob outras formas. Mas eles aprenderam que as formas não garantem o fundo" (CONSTANT, 2005d, II, p. 922). Além disso, como sublinha o autor, ele já havia reconhecido pouco antes, em De l'esprit de conquête, "a possibilidade da liberdade sob a monarquia, distinguindo-a ao mesmo tempo da usurpação e do despotismo" (CONSTANT, 2005d, II, p. 922). Conhecido por ter sustentado, em Des suites de la contre-révolution de 1660 en Angleterre, de 1799, a impossibilidade de restaurar a monarquia na França sem mergulhar o país no despotismo e na vingança violenta dos contrarrevolucionários, Constant argumenta, agora, que a França de 1814 reúne condições diferentes das da Inglaterra de 1660 (o exemplo que ele havia mobilizado, em 1799, para demonstrar os furores despóticos de uma eventual restauração monárquica). Reunindo ao retorno da dinastia legítima a consagração da representação nacional, da liberdade de imprensa e da 
independência dos tribunais, a França de 1814 combinaria as "revoluções" inglesas de 1660 e 1688, sem possuir as desvantagens de nenhuma das duas - a ausência de garantias contra o arbítrio em 1660, e a ascensão de uma dinastia com legitimidade contestada em 1688.

Apesar de apoiar a monarquia constitucional assim que ela se anuncia como o horizonte político da França, Constant tem, desde esse momento, a consciência de que seria preciso disputar a natureza desse regime. Em 2 de maio de 1814, na famosa declaração de Saint-Ouen, Luís XVIII adere à ideia de monarquia constitucional, mas rejeita a Constituição elaborada pelo Senado Conservador, anunciando que a nova Constituição deveria partir de sua autoridade e ser outorgada por ele próprio. O próprio Rei se prontifica, então, a formar a comissão encarregada de elaborar a Carta de 1814, promulgada em 4 de junho daquele ano. É em meio a esse processo que Constant retoma seu projeto de elaboração constitucional, abandonado desde os Fragments, mas adaptando-o agora ao contex to de uma monarquia constitucional. Em 24 de maio de 1814, ele publica as Réflexions sur les constitutions, la distribution des pouvoirs et les garanties, dans une monarchie constitutionnelle, seu primeiro projeto constitucional vindo a público (já que os Fragments não foram publicados em vida), como uma tentativa de influenciar a Constituição em vias de elaboração pela comissão formada por Luís XVIII. Como nota Rosanvallon, nosso autor é, nesse momento, "um dos raros a propor uma verdadeira teoria do novo sistema a ser edificado" (ROSANVALLON, 1994, p. 63), o debate público sobre a natureza da monarquia constitucional se aprofundando apenas nos anos seguintes. Todavia, as Réflexions não influenciam diretamente a redação da Carta de 1814, a qual, apesar das concessões liberais, procura estabelecer alguma continuidade com a monarquia do Antigo Regime e com a ideia de um Rei soberano e detentor do Poder Executivo, rejeitada por Constant. ${ }^{109}$

${ }^{109}$ De acordo com a classificação de Stéphane Rials, a Carta de 1814 institui uma "monarquia limitada", isto é, um regime fundado na unidade do poder soberano na pessoa do monarca, o qual consente livremente em autolimitar seu poder pelo estabelecimento de câmaras munidas de um poder de veto. Já a monarquia constitucional de Constant, Rials a classifica como figurando "entre o regime com Executivo monárquico e o regime em forma monárquica" (RIALS, 1987, p. 87; ênfases do autor) - isto é, pertencendo à família dos regimes que, apesar de conter a figura de um rei, não atribuem ao monarca a unidade do poder do Estado, sendo, nesse sentido, apenas parcialmente monárquicos. Ver os ensaios "Monarchie et 
Isso não impede nosso autor de interpretar a Carta de 1814 à luz de sua própria visão sobre a monarquia constitucional. Essa tarefa era possibilitada pelo caráter relativamente vago da Carta, escrita com o intuito de contentar tanto liberais como monarquistas por meio de uma alusão imprecisa às instituições inglesas (ROSANVALLON, 1994, p. 62), dando margem para diversas interpretações do mesmo documento. É nessa chave que podemos ler textos como De la responsabilité des ministres, publicado por Constant em fevereiro de 1815: uma vez que a Carta de 1814 estabelecia a responsabilidade dos ministros de modo vago, permitindo que os artigos sobre essa matéria fossem precisados por leis posteriores, o autor se apressa em fornecer ao público uma interpretação da responsabilidade ministerial que aproximasse a Constituição em vigor de sua teoria mais ampla da monarquia constitucional.

Em março de 1815, uma reviravolta extraordinária coloca Constant no centro dos acontecimentos políticos da França, de modo totalmente imprevisto. Napoleão escapa de seu exílio na Ilha de Elba, desembarca na França e, em 20 de março, é recebido triunfalmente em Paris, tornando-se novamente o senhor da nação. Durante o percurso de Bonaparte de Vallauris a Paris, de $1^{\circ}$ a 20 de março de 1815, nosso autor reedita a retórica antinapoleônica de De l'esprit de conquête, conclamando, em artigos de jornal, o povo francês a resistir ao tirano que marchava para se apossar da capital. O que Constant provavelmente não imaginava era que, uma vez reinstalado no poder, o Imperador se mostraria mais simpático a acolher suas ideias em um projeto de Constituição do que havia se mostrado Luís XVIII. Desejoso de convencer a França de que, a partir daquele momento, ele estava disposto a reinar como rei constitucional e liberal, Napoleão se reúne com o autor de De l'esprit de conquête, nomeia-o ao Conselho de Estado e o encarrega de ser o autor principal do Ato Adicional às Constituições do Império, a nova Constituição a ser oferecida à nação, apelidada de "la Benjamine". Em 22 de abril de 1815, as ideias de Constant sobre a monarquia constitucional se encontravam inscritas em uma Constituição assinada pelo Imperador, e aprovada em plebiscito em $1^{\circ}$ de junho daquele ano. Por ironia da História, o homem que, há pouco mais de um mês, era retratado por Constant como o protótipo do déspota, portanto como a antítese perfeita do rei constitucional, tornava, por um breve momento, sua visão da monarquia constitucional a teoria oficial do regime a ser construído. É justamente como teoria oficial da nova

philosophie politique: un essai d'inventaire" (RIALS, 1987, p. 71-87) e "Essai sur le concept de monarchie limitée (autour de la Charte de 1814) " (RIALS, 1987, p. 88-125). 
Constituição que Constant publica, em 31 de maio de 1815, os Principes de politique applicables à tous les gouvernements représentatifs et particulièrement à la Constitution actuelle de la France. Apesar da analogia com o título do livro não publicado de 1806 (o objeto do Capítulo 3 desta tese), do qual o autor extrai principalmente a reflexão sobre a limitação da soberania do povo, os dois livros têm objetos distintos: em 1806, o objeto eram os princípios da liberdade individual, considerados independentemente de qualquer discussão sobre constituições e formas de governo; em 1815, trata-se de expor os fundamentos de uma Constituição específica, o Ato Adicional proclamado naquele ano. No fundo, é o conteúdo das Réflexions exibido na forma de teoria oficial do regime recéminaugurado. O objeto continua sendo a monarquia constitucional.

Infelizmente, para nosso autor, Napoleão é derrotado definitivamente na Batalha de Waterloo, em 18 de junho de 1815. Em 22 de junho, sua abdicação põe fim ao Governo dos Cem Dias, como ficou conhecido esse breve período do Imperador novamente no poder. O clima de intimidação contra os que apoiaram Bonaparte durante os Cem Dias leva Constant a se exilar na Bélgica e depois na Inglaterra, retornando à França apenas em 1816, após Luís XVIII dissolver a "Chambre introuvable" e abrir espaço para uma política mais liberal. Inicia-se aí uma intensa atividade intelectual, jornalística e política, por meio da qual nosso autor se consagra paulatinamente como um dos grandes líderes do partido liberal em formação na França da Segunda Restauração. Em diversos momentos dessa carreira intelectual, jornalística e política, o objetivo de Constant é persuadir seus contemporâneos a agir em conformidade com sua visão da monarquia constitucional, buscando novamente interpretar no sentido de sua teoria política a Carta de 1814, posta novamente em vigor, com pontuais modificações, após a segunda abdicação de Napoleão.

O objeto deste capítulo é essa teoria da monarquia constitucional elaborada por Constant nos anos de 1814 e 1815, e mobilizada em seus quinze anos restantes de existência. ${ }^{110}$ A hipótese a ser sustentada é que a monarquia constitucional constantiana

110 Apesar da intensa atividade intelectual, jornalística e política desempenhada de 1815 a 1830, essa última etapa da vida de Constant não é mais marcada por verdadeiras inflexões em seu pensamento. O vasto material publicado nesse período tem, em geral, sua base elaborada nos anos anteriores a 1815, o autor se contentando em publicar, muitas vezes com a reprodução integral de passagens inteiras, um pensamento formulado, em suas linhas essenciais, antes da Segunda Restauração. É por isso que esta tese, interessada na evolução do problema do arbítrio na obra de Constant, não trata em pormenores o período 
procura realizar as duas modalidades de incorporação controlada do arbítrio estudadas nos dois capítulos anteriores desta tese: por um lado, o arbítrio deve ser concentrado em um poder (neutro) encarregado de agir discricionariamente e frear os demais poderes quando eles parecem pôr em risco a Constituição (ver Capítulo 2); por outro lado, o arbítrio deve ser difundido no interior do edifício constitucional, na forma de um julgamento moral individual autorizado a avaliar os limites e o potencial tirânico das leis estabelecidas (ver Capítulo 3).

Na Seção 4.1, analisamos a versão monárquica do poder neutro apresentada em 1814-15, buscando compreender quais novas nuances a "autoridade discricionária" elaborada inicialmente nos Fragments, e examinada no Capítulo 2 desta tese, passou a ter após a conversão de Constant à monarquia constitucional. Interessa-nos compreender, sobretudo, com quais vertentes da tradição monarquista francesa nosso autor dialoga ao fazer do poder régio o poder neutro buscado desde os Fragments, e de que modo as noções de decisão discricionária e inviolabilidade são centrais nesse diálogo com a tradição monarquista. O foco da Seção 4.2 é a teoria constantiana da responsabilidade dos ministros. A hipótese, a esse respeito, é que o mecanismo da responsabilidade ministerial é o paradigma por excelência por meio do qual Constant pensa a disseminação do arbítrio no edifício constitucional, para além do poder neutro. É principalmente nesse âmbito que podemos notar que a monarquia constitucional constantiana não é apenas uma adaptação da elaboração constitucional republicana dos Fragments ao novo contexto da França da Restauração, no qual era preciso encontrar um lugar em sua teoria para a realeza e o pariato, mas também um esforço para institucionalizar o princípio da insuficiência da lei desenvolvido nos Principes de politique de 1806, bem como o da necessidade de os indivíduos poderem decidir discricionariamente quando julgam a lei insuficiente. Por fim, a Seção 4.3 situa a monarquia constitucional constantiana perante outras interpretações da Carta de 1814, e particularmente da responsabilidade dos ministros, com o intuito de demonstrar a particularidade de nosso autor no que tange à incorporação e à disseminação do arbítrio no interior do sistema institucional. A hipótese é que, a partir da Segunda Restauração (posteriormente, portanto, à elaboração teórica precoce de Constant, que fundamenta toda a sua visão da monarquia constitucional durante a

da Segunda Restauração, encerrando-se com o confronto entre interpretações parlamentaristas e antiparlamentaristas da Carta de 1814 deflagrado pela experiência da "Chambre introuvable" (1815-1816) e com as reações de Constant a esse debate. 
Primeira Restauração e os Cem Dias), é elaborada uma interpretação parlamentarista da Carta de 1814 (por parte do Barão de Vitrolles e do Visconde de Chateaubriand, notadamente), assim como uma crítica dessa interpretação (por François Guizot, Abel François Villemain e Marchais de Migneaux, principalmente), a qual concentra o poder no Rei e nega uma responsabilidade política dos ministros diante das Câmaras, para além da responsabilidade estritamente jurídica. Em ambas essas interpretações da Carta de 1814, o papel primordial do arbítrio na política, ressaltado na interpretação de Constant sobre a responsabilidade dos ministros, é negado, buscando-se submeter a dinâmica política, e particularmente a responsabilidade dos ministros, a princípios fixos. Com isso, parece-nos demonstrado o lugar de Constant como eminente teórico do arbítrio, em contraste com outras leituras da política que cabia à França pós-revolucionária e pósnapoleônica.

\subsection{A versão monárquica do poder neutro e a imersão de Constant na tradição monarquista}

O fato de Constant ter passado de defensor intransigente da República durante o Diretório e o Consulado a partidário da monarquia constitucional a partir de 1814, chegando a apontar este último regime como superior ao republicano, não apenas lhe causou adversidades na luta política - seus adversários à direita não se cansavam de lembrar seu passado republicano para desacreditar perante o público sua lealdade ao regime da Restauração e à Carta de 1814 -, mas criou também certa clivagem entre seus intérpretes contemporâneos. Por um lado, há uma interpretação republicana de Constant, segundo a qual a República sempre foi seu regime favorito, e o autor precisou aderir à monarquia constitucional apenas como uma concessão ao momento histórico. De acordo com essa interpretação, a monarquia constitucional constantiana é uma República que precisou acomodar a realeza e o pariato, já que essas instituições eram impostas pelas circunstâncias. Segundo Fontana (1991, p. 64), a adesão de Constant às instituições da monarquia constitucional "era meramente uma escolha ditada por razões de oportunidade, realismo histórico e prudência prática":

De modo geral, Constant mostrou uma forte preferência pelas instituições republicanas, na medida em que seu modelo político se baseava na soberania popular, na abolição do privilégio hereditário e na igualdade política. Nesse 
sentido, não há mudança detectável em sua posição teórica desde os primeiros escritos até os anos da Restauração (FONTANA, 1991, p. 65).

Luís Falcão também privilegia o republicanismo de Constant: "os princípios de política são mais espontaneamente afeitos às repúblicas" (FALCÃO, 2011, p. 192). "Com vantagens e desvantagens, os princípios de todos os governos são, de fato, princípios republicanos" (FALCÃO, 2011, p. 213). "Nesse sentido, a república é mais propensa à liberdade e à justiça que qualquer tipo de monarquia" (FALCÃO, 2011, p. 215).

Por outro lado, uma linha alternativa de interpretação vê o constitucionalismo de Constant como mais afeito à monarquia constitucional, inclusive quando o autor se propunha a estabelecer uma Constituição republicana. Os autores dessa linha de interpretação argumentam pela origem monárquica da ideia de poder neutro, de modo que, mesmo quando Constant formula um poder neutro republicano, nos Fragments, sua fonte de inspiração seriam ideias monarquistas. Segundo Gauchet, "Constant se esforçou metodicamente para naturalizar, de alguma forma, no interior de um sistema fundado sobre a representação, um elemento derivado da antiga visão monárquica do poder" (GAUCHET, 1997, p. 34). Mesmo quando seu objetivo era formular uma Constituição republicana, o esforço do autor seria para "introduzir no edifício das instituições uma instância que salvaguardasse as dimensões de eminência, de permanência e de independência que se ligavam à pessoa do monarca" (GAUCHET, 1997, p. 35). ${ }^{111}$ Com isso, Constant recuperaria de fato, embora com uma mudança de sinal, "elementos extraídos fortemente das críticas conservadoras da ideia revolucionária, notadamente a anterioridade da ordem social em relação à vontade dos indivíduos" (GAUCHET, 1997, p. 36).

Em uma análise próxima da de Gauchet, Christian Lynch vê o poder neutro de Constant no quadro de uma fíliação do autor "à prática institucional britânica, cuja estabilidade ele atribuía ao papel de arbitragem exercido pelo monarca na manutenção da Constituição Inglesa" (LYNCH, 2007, p. 74). Segundo Lynch, Constant teria inicialmente transposto a Constituição Inglesa para o regime republicano, mas não teria ficado satisfeito com o resultado, pois "a confiança numa instituição não era matéria apenas de engenharia institucional, mas de um poder simbólico inscrito na tradição" (LYNCH, 2007, p. 77). O advento da monarquia constitucional, a partir de 1814, teria

111 "Para o próprio Constant, as coisas são perfeitamente claras: sua ideia do poder neutro, ele o diz desde 1802, é uma ideia de origem monárquica” (GAUCHET, 1997, p. 105). 
permitido ao autor resolver as dificuldades de sua teoria, a qual já penderia implicitamente para essa forma de governo: “A queda da autocracia bonapartista em 1814 e a restauração dos Bourbons na França, sob uma constituição que comportava o governo representativo, resolveu na prática o problema teórico de que Constant não conseguia se desembaraçar" (LYNCH, 2007, p. 77).

Tanto Gauchet como Lynch se apoiam, nessa leitura "monarquista" de Constant, nas referências do autor a Stanislas de Clermont-Tonnerre, um dos líderes do "partido monarquiano" no período da Assembleia Nacional Constituinte. ${ }^{112}$ Em Analyse raisonnée de la Constitution française, publicada em setembro de 1791, Clermont-Tonnerre asseverava: "O rei tem em si dois poderes perfeitamente distintos, o poder régio e o Poder Executivo" (CLERMONT-TONNERRE, 1791, p. 392). Essa distinção estabelecida pelo monarquiano é, de fato, uma das inspirações de Constant em sua reflexão sobre o poder neutro, desde a versão republicana desse poder, como se percebe na seguinte passagem dos Fragments (citada por Gauchet ${ }^{113}$ e Lynch ${ }^{114}$ ):

Uma das maiores vantagens da Realeza consiste em ter constituído, de certa forma, o direito de destituição entre as mãos do rei. Um partidário esclarecido dessa forma de governo (o Sr. Clermont-Tonnerre) observa que há, no poder monárquico, dois poderes: o Poder Executivo, investido de prerrogativas positivas; e o poder régio, composto de lembranças e de ilusões religiosas ou tradicionais. Este último é, de certa forma, um poder neutro entre o povo e o Poder Executivo propriamente dito, o qual é sempre delegado a ministros (CONSTANT, 1991, p. 398).

A referência a Clermont-Tonnerre se torna ainda mais explícita nas Réflexions, nas quais, logo na abertura do Capítulo 1, Constant faz da distinção entre o poder régio e o Executivo a chave de sua concepção de monarquia constitucional, atribuindo essa distinção ao antigo monarquiano:

Muitos acharão estranho eu distinguir entre o poder régio e o Poder Executivo. Essa distinção, ainda desprezada, é muito importante. Ela é, talvez, a chave de toda organização política. Eu não reivindico a honra de sua descoberta: seu germe se encontra nos escritos de um homem muito esclarecido (o $\mathrm{Sr}$. Clermont-Tonnerre) que morreu violentamente durante nossas agitações, como quase todos os homens esclarecidos (CONSTANT, 1814, p. 1-2).

112 Sobre o "partido monarquiano", ver principalmente o Capítulo 1 da tese de Lynch, especialmente a seção 1.2: "O discurso monarquiano e o conceito de Poder Moderador nos primeiros anos da Revolução Francesa” (LYNCH, 2007, p. 53-67). Ver também CRAIUTU, 2012, Cap. 3.

${ }^{113}$ GAUCHET, 1997, p. 106.

${ }^{114}$ LYNCH, 2007, p. 74, n. 22. 
O peso atribuído à influência de Clermont-Tonnerre é justamente um dos fatores em disputa por essas duas interpretações de Constant de que estamos tratando: a republicana e a monarquista. Mauro Barberis, partidário da interpretação republicana, minimiza a influência do monarquiano, o qual só seria citado por Constant “com o objetivo de ocultar outras fontes" (BARBERIS, 1996, p. 134) - especialmente Sieyès, e, de modo mais geral, o debate sobre a reformulação da Constituição republicana de 1795 após o golpe do 18 Frutidor, tratado no Capítulo 2 desta tese -, no que é rebatido por Lynch (2007, p. 74, n. 22). Vale lembrar que, em outros escritos, mais para o fim de sua vida, Constant destacou Sieyès, mais do que Clermont-Tonnerre, como o maior inspirador da monarquia constitucional defendida por ele. Assim, nos Souvenirs historiques, publicados entre fevereiro e junho de 1830 na Revue de Paris, o autor afirma que Sieyès "contribuiu, mais do que ninguém, para estabelecer as bases da monarquia constitucional. Ele foi o primeiro, na França, a estabelecer e provar que o chefe, situado no topo da hierarquia política, devia escolher, mas não governar" (CONSTANT, 1992, p. 77). Constant tinha em mente o Grande Eleitor pensado por Sieyès para a Constituição do Ano VIII, tratado no Capítulo 2 desta tese (cf. p. 130-132 supra). Essa figura imaginada pelo ex-abade seria "o tipo exato e útil de um rei, tal como se deve desejá-lo" (CONSTANT, 1992, p. 77). Em outras palavras, o autor franco-suíço misturou fontes monarquistas e republicanas como inspirações declaradas de seu modelo de monarquia constitucional.

Esta tese não se filia propriamente nem à interpretação republicana, nem à interpretação monarquista de Constant. Em nossa perspectiva, ambas incorrem na mitologia da coerência denunciada por Skinner (2002a, p. 67) e Rosanvallon (1986, p. 99), já criticada no Capítulo 2 desta tese (cf. p. 103-104 supra). Nas duas interpretações, Constant teria professado durante toda a vida uma mesma doutrina constitucional coerente, seja ela republicana ou monárquica, adaptando seu republicanismo à conjuntura da Restauração, na primeira leitura, ou seu monarquismo à inglesa ao contexto republicano do Diretório e do Consulado, na segunda interpretação. Parece-nos mais interessante a hipótese de que Constant procurou assentar a República sobre princípios republicanos, e, depois, a monarquia constitucional sobre princípios monárquicos. Kalyvas e Katznelson desenvolvem uma interpretação próxima da sugerida aqui, na medida em que consideram os Fragments como uma construção institucional eminentemente republicana, os Principes de politique de 1806 como uma virada liberal do autor, e os Principes de politique de 1815 como "uma articulação mais sincrética entre 
os pensamentos democrático, liberal e monárquico" (KALYVAS; KATZNELSON, 2008, p. 149).

Desse modo, podemos situar o poder neutro desenvolvido nos Fragments no quadro de um diálogo de Constant com a tradição republicana, em uma leitura diferente da de Gauchet e Lynch, mas remeter o poder neutro monárquico teorizado a partir de 1814 a um diálogo que, sem desconsiderar os raciocínios republicanos que presidiram à primeira elaboração da instituição, busca incluir também a tradição monarquista, de modo a diferir também da interpretação republicana de Fontana, Falcão e Barberis. Nos dois primeiros capítulos desta tese, propusemos compreender o poder neutro dos Fragments como uma primeira resposta ao problema do arbítrio que rondava o autor desde 1795 , quando, por ocasião do debate sobre os decretos dos dois terços, Constant se confronta pela primeira vez com o problema da legitimidade das medidas arbitrárias empregadas para salvar a República de si mesma (ou seja, de um eleitorado eventualmente hostil a essa forma de governo) (ver Capítulo 1). Negando, em um primeiro momento, a legitimidade de toda e qualquer medida arbitrária, o autor é obrigado a reformular seu pensamento a partir da prova do 18 Frutidor, do que resulta a versão republicana do poder neutro construída nos Fragments (ver Capítulo 2). Como sugerimos no início do Capítulo 3, retomando e resumindo o argumento dos dois primeiros capítulos, o problema do arbítrio era diretamente associado ao da conservação da República em momentos de crise, o poder neutro dos Fragments buscando responder a um problema análogo ao que a tradição republicana, de Maquiavel a Rousseau, havia procurado resolver por meio da instituição romana da ditadura: como conservar a República quando ela atravessa perigos que não podem ser enfrentados pelo simples seguimento da lei? Em resumo, o poder neutro dos Fragments se inseria em uma problemática eminentemente republicana, assim como outras respostas ao golpe do 18 Frutidor exploradas no Capítulo 2 da tese, como as de Staël e Sieyès.

Como sugerido acima, essa problemática republicana permanece implícita nas obras escritas a partir de 1814, mas, a partir desse momento, o diálogo de Constant com a tradição monarquista acrescenta novas feições ao conceito de poder neutro, de modo que a ideia de uma simples adaptação de seu republicanismo ao contexto da Restauração tampouco pode nos satisfazer. É necessário levar em consideração esse novo mergulho de Constant na tradição monarquista, a fim de compreender o poder neutro formulado a partir de 1814. 
Qual tradição monarquista? Teses recentes como as de Christian Lynch (2007) e Roberta K. Soromenho Nicolete (2017) nos ajudam a mapear algumas das diversas linguagens políticas que, desde a França pré-revolucionária, procuravam estabelecer a natureza e os fundamentos da autoridade monárquica. Segundo Lynch (2007, p. 43), os discursos de oposição à monarquia absoluta de direito divino (hegemônica no século XVII) em voga na França de meados do século XVIII eram o constitucionalismo antiquário (calcado na justiça), o despotismo ilustrado (calcado na razão) e o republicanismo democrático (calcado na vontade). Nicolete, por sua vez, joga luz sobre a proeminência da chamada tese parlamentar na França da década de 1770, com "patriotas" como Martin Morizot, Jean-Claude Marivaux e Guillaume-Joseph Saige defendendo a origem eletiva da monarquia e fundamentando a autoridade régia em uma linguagem constitucionalista que determinava a soberania do povo (NICOLETE, 2017, Caps. 2 e 3). Por outro lado, essa tese parlamentar era atacada por uma tese real que, vocalizada por autores como Leroy de Barincourt, Pierre-Louis-Claude Gin e Jean Pey, via na centralização do governo na figura do Rei a única garantia das leis e da liberdade dos súditos contra o abuso e o arbítrio de poderes privados (NICOLETE, 2017, Cap. 4). Trabalhos como os de Lynch e Nicolete demonstram que, antes mesmo da eclosão da Revolução Francesa, havia diversas linguagens políticas disponíveis para a fundamentação de uma monarquia não absoluta.

Importa ressaltar, contudo, que nenhuma dessas linguagens políticas disponíveis desde o Antigo Regime parece ter sido percebida por Constant como adequada para fundamentar sua monarquia constitucional. Atendo-se às três linguagens políticas elencadas por Lynch, percebemos que, em primeiro lugar, o constitucionalismo antiquário, com seu projeto de limitar a monarquia por meio dos Parlements (tribunais aristocráticos apresentados pelos antiquários como representantes da Nação), não podia agradar a um herdeiro da Revolução Francesa como Constant, que, apesar de sua concessão a uma câmara legislativa hereditária, passou a vida inteira recusando instituições políticas fundadas no antigo princípio nobiliárquico. Quanto ao despotismo ilustrado, trata-se de outro alvo recorrente de nosso autor ao longo de sua vida: para ele, não cabe ao Estado (e muito menos ao Rei) impor ideias que ainda não se tornaram dominantes na sociedade, e os governos que se autoproclamam "amigos das luzes" não fazem mais do que atrapalhar o progresso natural das opiniões. Quanto ao republicanismo democrático, atribuído por Lynch a Rousseau, Mably e Saige, Constant pode ter se 
inspirado na crítica desses autores à aristocracia e ao absolutismo monárquico, mas, para se ater ao objeto deste capítulo, ele não podia se contentar, durante a Restauração, com o papel que eles haviam conferido à realeza (isso quando a admitiam). Para os republicanos democráticos, o papel do Rei era o Poder Executivo, e este deveria se subordinar completamente ao Legislativo: ao Legislativo, caberia a vontade; ao Executivo, a execução. Ora, Constant conceberá para a realeza um poder distinto do Executivo, e, no exercício desse poder, haverá uma margem (limitada) para a decisão discricionária.

Se considerarmos as linguagens elencadas por Nicolete, tampouco encontramos uma fonte de inspiração possível para Constant. A tese parlamentar, a esse respeito, incorria na mesma dificuldade do republicanismo democrático tratado por Lynch: ${ }^{115}$ ao menos em suas versões mais radicais, o Rei era tratado como "um comissário, a primeira pessoa do estado", ou um "agente do soberano" (NICOLETE, 2017, p. 143). A Nação soberana se tornava independente do Rei, adquirindo o direito de o destituir e modificar a Constituição à vontade. Ora, para Constant, será fundamental a transcendência simbólica do Rei em relação à Nação (o que estava longe de significar poder absoluto, mas diferia sensivelmente da condição de "comissário" ou "agente do soberano"), bem como sua inviolabilidade, ou seja, a impossibilidade de ser destituído. Nosso autor não se encontraria melhor com a tese real referida por Nicolete: apesar de defender a transcendência simbólica do monarca, ele era um partidário convicto do equilíbrio de poderes e um crítico ferrenho da centralização e da concentração de poderes na pessoa do Rei, situando-se no polo oposto ao das teses absolutistas e centralizadoras de Barincourt, Gin e Pey.

Portanto, se, como sugerimos, Constant mergulha em uma tradição monarquista a partir de 1814, que tradição monarquista seria essa? Nossa hipótese é que os elementos monarquistas incorporados pelo Constant da Restauração só fazem sentido à luz de uma reação ao trauma da Revolução Francesa. ${ }^{116}$

No período da Assembleia Nacional Constituinte (1789-1791), as linguagens políticas elencadas por Lynch e Nicolete se digladiaram sobre a natureza da monarquia

\footnotetext{
115 Vale notar que ambas as linguagens têm um autor em comum: Saige.

${ }^{116}$ Para um aprofundamento dessa noção de um trauma produzido pela Revolução Francesa, ver: BRAHAMI, 2016, especialmente o Capítulo 1 (“L’effroi”).
} 
que se tratava de refundar. Lynch caracteriza o discurso monarquiano, influente durante os primeiros meses da Constituinte, como

(...) uma tentativa de transpor a tradição do despotismo ilustrado, convertido
pelos fisiocratas numa ciência do Estado modernizador, para o universo do
constitucionalismo representativo, baseado numa interpretação da
Constituição Inglesa como um governo misto cujo elemento central era o
monarca (LYNCH, 2007, p. 57).

Ou seja, tratava-se de uma fusão do despotismo ilustrado com uma versão modernizada do constitucionalismo antiquário, baseada em certa leitura da Constituição Inglesa. A esse discurso, contrapunham-se monarquistas republicanos como Le Chapelier, Talleyrand e Sieyès, "cujo projeto político descendia do republicanismo democrático de Rousseau, Mably e Saige" (LYNCH, 2007, p. 59). Como se sabe, os monarquianos foram derrotados pelos monarquistas republicanos em setembro de 1789 , quando a Constituinte recusou o projeto monarquiano com duas câmaras e um Rei dotado do direito de veto absoluto, aderindo à concepção de uma soberania nacional concentrada em uma Assembleia única, à qual o Rei, simples delegado da Nação, deveria se subordinar (cf. p. 51 supra). O que importa ressaltar é que esses discursos em disputa nos primeiros anos da Revolução Francesa tampouco podiam servir de inspiração à monarquia constitucional constantiana, tributários que eram das linguagens políticas já formuladas durante o Antigo Regime - anteriores, portanto, ao trauma do regicídio.

Cabe, aqui, sublinhar a distância entre a monarquia constitucional de Constant e a dos monarquianos, apesar das referências do primeiro a Clermont-Tonnerre, mencionadas acima. Lynch já destacou a divergência de Constant com todos os aspectos do discurso monarquiano decorrentes da herança do despotismo ilustrado (cf. LYNCH, 2007, p. 70), mas é preciso ir além. Quando Clermont-Tonnerre distingue, na pessoa do Rei, o poder régio do Executivo, não é de modo algum, como fará Constant, para pensar o poder régio como separado do Executivo. Pelo contrário, se os monarquianos viam a necessidade de manter o Rei em uma posição elevada, era porque, assim como Necker (que os apoiava), eles viam o Poder Executivo como central na sociedade e no Estado modernos. A distinção entre poder régio e Executivo estabelecida por Clermont-Tonnerre não tem a intenção de despojar do Rei o Poder Executivo, mas, pelo contrário, a de acrescentar a esse Poder Executivo uma parte do Legislativo, fazendo do monarca um colegislador. Ao invocar o poder régio, que transcende o Executivo, o monarquiano tem o objetivo de criticar "os sistemas que fazem do rei um simples funcionário público, um comissário da nação, a qual lhe dita suas leis pelo órgão do corpo legislativo; o que significa, em última 
análise, um comissário da Assembleia Nacional" (CLERMONT-TONNERRE, 1791, p. 393). A ideia de poder régio teria feito a Constituinte considerar de modo muito mais elevado a posição do monarca: "teriam visto que o poder régio deveria torná-lo colegislador e dar-lhe uma influência não ilusória sobre a lei" (CLERMONTTONNERRE, 1791, p. 393). Em outras palavras, a preocupação de Clermont-Tonnerre, e dos monarquianos de modo geral, era oposta à de Constant: os primeiros queriam assegurar ao Rei sua parte devida no governo e na legislação; o segundo queria, ao contrário, desvincular o poder régio de qualquer participação no governo e na legislação. $\mathrm{O}$ único ponto comum entre Constant e os monarquianos era sua crítica à visão do monarca como um simples comissário da Nação soberana. Esse é outro modo de dizer que nosso autor não aderia a nenhuma das visões que se digladiaram na Constituinte: nem ao discurso monarquiano, nem ao dos monarquistas republicanos então liderados por Sieyès.

Entre esse debate da Constituinte (ocorrido principalmente em agosto e setembro de 1789) e a elaboração da teoria constantiana da monarquia constitucional, ocorre a erosão da autoridade monárquica, culminando na execução de Luís XVI, em 21 de janeiro de 1793 - um evento que todos tinham vivamente na memória quando o irmão do Rei guilhotinado ascende ao trono, em 1814. Nicolete destaca o episódio da fuga de Varennes (20-21 de junho de 1791) como crucial para "a desmontagem da peça jurídica da inviolabilidade real” (NICOLETE, 2017, p. 171) - desmontagem esta que permitirá o julgamento e a condenação à morte do Rei pouco mais de um ano depois, em um contexto em que ele já se encontrava destituído do cargo, após a Revolução de 10 de agosto de 1792.

Nossa hipótese é que essa implosão da peça jurídica da inviolabilidade real, seguida pelo julgamento e condenação do Rei após sua destituição do cargo, engendram um novo discurso sobre a autoridade monárquica da parte dos que sonham em restaurála. Esse novo discurso produz um fosso entre as vertentes monarquistas formuladas antes do regicídio, exploradas até aqui por meio das teses de Lynch e Nicolete, e a tradição monarquista construída a partir do trauma da execução de Luís XVI, a qual vê nesse evento a principal questão a compreender e o episódio cuja repetição deve ser impedida a todo custo. Quando sugerimos que, a partir de 1814, Constant faz uma imersão na tradição monarquista francesa, é a essa tradição monarquista pós-regicídio que fazíamos referência. 
O contrarrevolucionário Joseph de Maistre é um autor emblemático dessa tradição monarquista obcecada com o episódio do regicídio. Se seu programa político é anular toda a obra da Revolução Francesa, sua teoria da monarquia se parece pouco com qualquer uma formulada antes da Revolução. É verdade que ele defende a origem divina da soberania e define esta última como "absoluta por natureza" (MAISTRE, 1992, p. 179), parecendo se apresentar como um teórico tradicional do direito divino dos reis saído do século XVII. No fundo, porém, os aspectos do regime monárquico enfatizados pelo autor só fazem sentido como uma resposta ao regicídio. A começar pela centralidade que ele confere à inviolabilidade na definição da soberania. É verdade que esse aspecto já estava presente nas teorias monarquistas do Antigo Regime. Entretanto, no caso de Maistre, a inviolabilidade não é, como naquelas teorias, uma condição para o exercício efetivo de poderes ligados ao governo e à legislação, mas a essência mesma da soberania, mesmo que o soberano não exerça poderes efetivos no âmbito do governo e da legislação: “O soberano não pode, portanto, ser julgado: se ele pudesse sê-lo, o poder que teria esse direito seria soberano" (MAISTRE, 1992, p. 180). Assim, a principal crítica do autor à Constituinte não é a de ter deixado o Rei estrangeiro à legislação e rebaixado o Poder Executivo - a principal crítica elaborada por Clermont-Tonnerre, os monarquianos e Necker -, mas a de ter enfraquecido o princípio da inviolabilidade régia, ao decretar os casos em que se consideraria que o monarca havia abdicado do trono:

\begin{abstract}
A Assembleia Constituinte dos franceses nunca se mostrou mais estranha a todos os princípios políticos, do que quando ousou decretar os casos em que se deveria supor que o rei havia abdicado da realeza. Essas leis destronavam o rei formalmente. Elas decretavam ao mesmo tempo que haveria e que não haveria um rei, ou, em outros termos, que a soberania não seria soberana (MAISTRE, 1992, p. 180-181; ênfase do autor).
\end{abstract}

Essa ênfase de Maistre na inviolabilidade como essência da soberania só faz sentido como uma resposta ao regicídio: após o trauma da execução do Rei, o que está em questão não são mais os poderes efetivos do monarca (o ponto que havia oposto monarquianos a monarquistas republicanos durante a Constituinte), mas o reconhecimento da impossibilidade absoluta de que o chefe de Estado seja levado a julgamento.

Além da inviolabilidade, Maistre enfatiza o poder simbólico do monarca, o qual, na prática, não precisa se traduzir em poderes efetivos. Curiosamente, ele concorda com a frase de Mirabeau segundo a qual "um rei é um ídolo que se coloca lá" (MIRABEAU 
apud MAISTRE, 1992, p. 190; ênfases do autor):"17 "Deixando de lado a forma repreensível desse pensamento, é certo que ele tem razão” (MAISTRE, 1992, p. 190). Para o contrarrevolucionário, o Rei não é uma potência efetiva, dotada de plenos poderes e encarregada de governar diretamente a sociedade, mas uma potência simbólica, em nome da qual tudo é feito, mas sem a necessidade de sua intervenção direta:

(...) A vontade do rei está infinitamente longe de fazer tudo na monarquia. (...). Supõe-se que ela faz tudo, e é esta a grande vantagem desse governo. Mas, de fato, ela não faz muito mais do que centralizar os conselhos e as luzes. A religião, as leis, os costumes, a opinião, os privilégios das ordens e dos corpos contêm o soberano e o impedem de abusar de seu poder. Chega a ser notável que os reis são acusados com muito mais frequência de falta de vontade do que de abusar dela. É sempre o conselho do príncipe que governa (MAISTRE, 1992, p. 191; ênfase do autor).

E, mais adiante:

Esta palavra de REI é um talismã, um poder mágico que dá a todas as forças e a todos os talentos uma direção central. Se o soberano tem grandes talentos, e se sua ação individual pode contribuir imediatamente para o movimento geral, trata-se de um bem, sem dúvida; mas, no lugar de sua pessoa, basta seu nome (MAISTRE, 1992, p. 195-196; ênfases do autor).

Precursor das teorias das elites, Maistre considera que, em todas as formas de governo (monarquia, aristocracia e democracia), quem governa, na prática, é a aristocracia do nascimento e da riqueza. O que muda é apenas o princípio em nome do qual essa aristocracia governa. A monarquia é concebida como "uma aristocracia centralizada" (MAISTRE, 1992, p. 190; ênfase do autor), na qual o governo da elite dirigente é legitimado pelo poder simbólico do Rei. Esse princípio de legitimidade tornaria esse governo muito mais suave do que o democrático, no qual o poder da aristocracia dirigente não se funda na lei e precisa se exercer pela força. Além disso, a supremacia universal (simbólica) do monarca atenuaria os sofrimentos de amor próprio decorrentes da inevitável desigualdade entre os seres humanos, o plebeu se contentando em ser tão súdito do Rei quanto o senhor mais poderoso (MAISTRE, 1992, p. 93). Acima de tudo, Maistre quer refutar a ironia feita por Rousseau contra os defensores da monarquia, acusados pelo filósofo genebrino de "atribuir liberalmente a esse magistrado [o rei] todas as virtudes de que ele tem necessidade e supor sempre que o príncipe é o que deveria ser" (ROUSSEAU, 2006, p. 93). Para o contrarrevolucionário saboiano, ao contrário, "o governo de um só é aquele em que os vícios do soberano têm menos

${ }^{117}$ Maistre extrai essa frase de De la monarchie prussienne sous Frédéric le Grand, publicado por Mirabeau em 1788. 
influência sobre os povos governados" (MAISTRE, 1992, p. 190). Ou seja, ao contrário da acusação feita por Rousseau, os monarquistas não precisariam pressupor nenhuma virtude no Rei, já que ele não é um poder efetivo, mas um símbolo. "O governo monárquico é precisamente aquele que mais dispensa a habilidade do soberano, e esta talvez seja mesmo a primeira de suas vantagens" (MAISTRE, 1992, p. 195). O governo monárquico seria uma máquina que pode ser posta em movimento pelo homem mais medíocre (MAISTRE, 1992, p. 195).

Por outro lado, esse símbolo seria ineficaz se sua vontade não fosse considerada, ao menos em certa instância, como absoluta. Como vimos, Maistre considera a soberania como absoluta, chegando mesmo a comparar essa soberania absoluta, existente em toda constituição, com o despotismo:

Toda espécie de soberania é absoluta por natureza. Podemos alocá-la sobre uma ou várias cabeças, podemos dividi-la, podemos organizar os poderes como quisermos: haverá sempre, em última análise, um poder absoluto que poderá fazer o mal impunemente, que será, portanto, despótico sob este ponto de vista, com toda a força do termo, e contra o qual não haverá outra fortaleza além da insurreição (MAISTRE, 1992, p. 179; ênfase do autor).

Brahami identifica, a partir dessa passagem, um decisionismo inerente ao pensamento de Maistre, o qual o distingue do outro grande teórico da contrarrevolução: Louis de Bonald. 118 "Para Maistre, a soberania não é tanto o fundamento do poder como seu exercício efetivo" (BRAHAMI, 2016, p. 170). Ao passo que Bonald considera a monarquia absoluta de Luís XIV como o modelo único de governo perfeito, enxergando nesse modelo a conformidade entre o exercício do poder e a vontade de Deus, Maistre é mais relativista, postulando que cada sociedade tem o governo que lhe convém, e, em cada governo, o soberano tem o direito de querer arbitrariamente, sem que essa vontade precise estar em conformidade com a palavra revelada de Deus:

Que a soberania venha de Deus não implica de modo algum, na obra de Maistre, que o poder se ordene segundo a palavra divina, notadamente segundo a palavra cristã. Ao passo que, na obra de Bonald, o homem-poder exerce o poder em virtude da vontade de Deus, para Maistre, a soberania não é tanto $\mathrm{em}$ Deus como ela vem de Deus. É por isso que o mais absoluto dos déspotas da Ásia não é de modo algum obrigado a promulgar leis conformes à Revelação. Recebendo seu poder de Deus, ele faz o que quer, na esfera do que pode, sem ter nunca contas a prestar (BRAHAMI, 2016, p. 171; ênfases do autor).

${ }^{118}$ Cabe sublinhar o papel de Maistre como fonte reconhecida de inspiração do decisionismo de Carl Schmitt (cf. SCHMITT, 2005, Cap. 4). Para um aprofundamento da particularidade de Maistre no seio do pensamento contrarrevolucionário, ver: PRANCHÈRE, 2004. 
Assim, além da inviolabilidade e do poder simbólico, o terceiro traço da monarquia de Maistre é o direito de decisão arbitrária, entendido como direito de querer invencivelmente: "O grande problema não seria, portanto, impedir o soberano de querer invencivelmente, o que implicaria contradição, mas impedi-lo de querer injustamente" (MAISTRE, 1992, p. 183; ênfases do autor).

Querer invencivelmente não é exercer a vontade sobre todas as coisas. Como vimos, na monarquia de Maistre, não é o Rei que governa, mas a aristocracia que governa em nome do Rei. A vontade do monarca é invencível, mas ela só se exerce sobre um círculo de coisas traçado informalmente pela opinião - o nome de Maistre para a vontade geral (BRAHAMI, 2016, p. 171). Nas monarquias europeias modernas, por exemplo, a opinião proibiria os reis de exercer pessoalmente o Poder Judiciário (MAISTRE, 1992, p. 197). Nessas monarquias, a própria oposição entre governo das leis e governo de um homem, estabelecida por Tácito, perderia o sentido, pois, ao contrário das monarquias antigas e asiáticas, os reis europeus modernos teriam consentido em deixar a maior parte das coisas a cargo das leis e da opinião (MAISTRE, 1992, p. 196).

Vê-se, assim, o quanto a monarquia teorizada por Maistre difere das vertentes monarquistas existentes na França pré-revolucionária, exploradas por meio dos trabalhos de Lynch e Nicolete, assim como das linguagens que se digladiaram no contexto da Constituinte. Se o contrarrevolucionário pregava uma elevação do poder régio, não era no sentido de concentrar poderes efetivos na pessoa do Rei, como haviam defendido os autores da tese real nas décadas anteriores à Revolução Francesa, nem no de assegurar a participação do monarca na legislação e no exercício pleno do Poder Executivo, como haviam sustentado Necker, Clermont-Tonnerre e os monarquianos. Para Maistre, a soberania régia poderia conviver muito bem com a separação dos poderes (como na Inglaterra), permanecendo intacta mesmo se o Rei delegasse a terceiros todos os ramos dos poderes Legislativo, Executivo e Judiciário, pondo-se à parte da administração direta dos negócios públicos. O importante era que: I) O Rei fosse verdadeiramente inviolável. Poderia haver separação dos poderes, mas nenhum poder poderia ter o direito de julgar o Rei. II) A transcendência simbólica do Rei em relação à nação fosse afirmada. O discurso que, derivado da tese parlamentar e do republicanismo democrático, fizera, no início da Revolução Francesa, do monarca o "primeiro funcionário da nação" quebrava, para Maistre, todo o poder simbólico do Rei e anulava a "magia" da monarquia, a qual consistia justamente em colocar um ídolo no centro simbólico do poder. III) O Rei 
pudesse "querer invencivelmente" (exercer uma vontade arbitrária) sobre o círculo de coisas posto a seu alcance pela opinião nacional, por menor que fosse esse círculo em uma nação europeia moderna.

A hipótese sustentada aqui não é a de que Maistre conta entre as influências de Constant. Seus projetos políticos eram tão antagônicos que isso dificilmente poderia ser sustentado. Mais do que os atributos da monarquia, estabelecidos de modo abstrato, o que estava em jogo naquele período era o triunfo ou a derrota da Revolução Francesa, Constant e Maistre encontrando-se em lados opostos dessa querela. Maistre se opunha à ideia de monarquia constitucional defendida por Constant: para o contrarrevolucionário, a monarquia deveria ser restaurada nos moldes do Antigo Regime (ou antes de uma versão idealizada deste), ou seja, como um governo paternal sem Constituição escrita, contido pelos direitos da nobreza, das corporações, da Igreja, pela possibilidade de endereçar remontrances ao Rei, etc. - em suma, nada mais distante do regime defendido por Constant. Além disso, nosso autor provavelmente não teve acesso aos trechos de Maistre citados aqui, extraídos de De la souveraineté du peuple, manuscrito não publicado escrito entre 1794 e 1795.

O ponto não é a influência direta de Maistre sobre Constant, mas antes a virada produzida pelo regicídio na tradição monarquista francesa, a qual influencia igualmente Maistre e Constant, distinguindo a monarquia de ambos dos discursos monarquistas formulados antes de 1793. Se nos detivemos por um instante na análise da monarquia de Maistre, foi para demonstrar os pontos que passaram a ser relevantes para a tradição monarquista francesa após o regicídio. Após esse trauma, a discussão sobre os poderes efetivos do Rei, sua relação com a Assembleia etc. fica para trás. Mesmo do ponto de vista de um contrarrevolucionário radical como Maistre, o importante não é restaurar um Rei que tenha poderes suficientes para governar diretamente a sociedade, mas um Rei que não seja levado novamente à guilhotina. Para isso, três atributos são fundamentais: a inviolabilidade, a supremacia simbólica (o rebaixamento a "primeiro comissário da nação" é visto como um primeiro passo em direção à guilhotina) e o direito de querer arbitrariamente em um círculo limitado (sem esse direito decorrente da soberania, a própria supremacia simbólica seria afetada).

Ora, esses serão também os três atributos do Rei na monarquia constitucional elaborada por Constant, dentro de um arcabouço teórico e institucional em tudo oposto ao de Maistre. Por um lado, as prerrogativas constitucionais conferidas pelo autor ao 
poder régio são basicamente as mesmas da versão republicana do poder neutro formulada nos Fragments: conter os abusos do Poder Legislativo dissolvendo a assembleia representativa, do Executivo destituindo seus membros (no caso, demitindo os ministros), e do Judiciário conferindo graça ou comutando penas. Nesse sentido, a existência de uma autoridade que age discricionariamente sobre os demais poderes - Constant não emprega mais a fórmula da "autoridade discricionária", mas a ideia permanece, inclusive a de uma autoridade correspondente à ballia florentina sem autorização para punir os indivíduos (CONSTANT, 1814, p. 16) - continua respondendo aos mesmos imperativos teóricos e políticos presentes na fase republicana do autor: se não se trata mais de proteger a República de si mesma, podemos dizer que se trata de proteger o regime livre de si mesmo, algumas das tensões do regime republicano podendo ser estendidas aos governos com participação popular de modo geral. Por outro lado, como já sugerimos, uma vez que se trata de uma monarquia constitucional, Constant procura incorporar a sua construção institucional elementos oriundos da tradição monárquica, especialmente aqueles que haviam se tornado candentes após a execução de Luís XVI. É nesse esforço que ele encontra os três atributos da monarquia de Maistre referidos acima.

No Prefácio das Réflexions, o autor trabalha com uma distinção entre Repúblicas e Monarquias, a qual indica bem quais aspectos da monarquia ele procurará incorporar:

Em um Estado republicano, deve-se dar ao povo toda a parte do governo que é compatível com a ordem, e revestir esse exercício dos direitos do povo de formas populares, mesmo tempestuosas; pois, em um governo republicano, a razão do povo é a garantia da ordem, e a razão do povo deve se formar e se amadurecer pela ação.

Sob uma monarquia, o Rei deve possuir todo o poder que é compatível com a liberdade, e esse poder deve ser revestido de formas imponentes e majestosas; pois, em uma monarquia, a segurança do monarca é uma das garantias da liberdade, e essa segurança só pode nascer da consciência de uma força suficiente (CONSTANT, 1814, p. viii).

Os franceses não teriam levado em sua devida consideração esses aspectos distintivos da República e da Monarquia, nem em sua tentativa de monarquia constitucional de 1789-1792, nem nas experiências republicanas que se seguiram:

Seguimos entre nós a regra oposta. Em nosso primeiro ensaio de monarquia constitucional, havíamos tido medo do Rei; em nossos ensaios de República, tivemos medo do povo: e tanto nossa monarquia constitucional como nossas Constituições republicanas colapsaram (CONSTANT, 1814, p. viii-ix).

Como toda a tradição monarquista posterior a 1793, a preocupação principal de Constant é evitar um novo regicídio, visto como um primeiro passo para o Terror. Se ele critica a Constituição de 1791, não é por ela ter tornado o Rei estrangeiro à legislação e 
rebaixado o Poder Executivo, como haviam criticado Necker e os monarquianos, mas por ela ter enfraquecido o princípio da inviolabilidade e da sacralidade simbólica da pessoa do monarca, tornando-o inseguro de sua posição - uma crítica que lembra mais a de Maistre. Se, nos Fragments, as características estruturais do poder neutro eram a vitaliciedade e a proibição de se candidatar a outras funções públicas, na monarquia constitucional, o principal traço estrutural do poder neutro é a inviolabilidade. É o fato de o Rei ser inviolável, ao passo que os ministros são responsáveis, que permite a Constant distinguir o Poder Executivo do poder supremo - uma distinção tornada mais difícil nas repúblicas, onde a necessidade de destituir os membros do Poder Executivo costuma resultar em crises insolúveis e golpes de Estado (CONSTANT, 1814, p. 14-16). Essa distinção seria perdida "seja rebaixando o poder régio ao nível do Poder Executivo, seja elevando o Poder Executivo ao nível do poder régio" (CONSTANT, 1814, p. 7) - ou seja, fazendo o Rei deixar de ser inviolável, ou os ministros deixarem de ser responsáveis. Assim, o principal erro da Constituição de 1791 foi rebaixar o poder régio ao Poder Executivo.

A supremacia simbólica do monarca, amparada em tradições, crenças e "formas imponentes e majestosas" (CONSTANT, 1814, p. viii) atribuídas à ação do Rei, é o segundo elemento da monarquia constitucional constantiana que pode ser comparado à monarquia de Maistre. Na segunda parte de De l'esprit de conquête, as tradições da realeza bem assentada no tempo já apareciam como elementos que suavizavam o poder do monarca, fazendo dele "um ser abstrato" (CONSTANT, 1997, p. 185-186) - em contraste com o rei usurpador (Napoleão), vetor de uma dominação pessoal e concreta. A partir das Réflexions, é esse aspecto abstrato do poder régio - revestido de um poder de opinião baseado em tradições e lembranças, mais do que em prerrogativas efetivas - que o capacita a exercer o poder neutro buscado desde os Fragments:

\footnotetext{
A monarquia constitucional tem essa grande vantagem, de criar esse poder neutro na pessoa de um Rei, já cercado de tradições e de lembranças, e revestido de um poder de opinião que serve de base a seu poder político. $\mathrm{O}$ interesse verdadeiro desse Rei não é, de modo algum, que um desses poderes derrube o outro, mas que todos se apoiem, se entendam e ajam em concerto (CONSTANT, 1814, p. 3).
}

A força do poder simbólico consiste em fazer o Rei e seus súditos acreditarem que ele é realmente "um ser à parte, superior às diversidades de opiniões, não tendo outro interesse além da manutenção da ordem e da liberdade, não podendo entrar nunca na condição comum, inacessível, portanto, a todas as paixões que essa condição faz nascer" 
(CONSTANT, 1997, p. 327). Como Maistre, Constant não precisa atribuir nenhuma virtude ao monarca para que ele desempenhe bem sua função. Ao poder simbólico do "talismã" colocado no centro do sistema político, soma-se o "princípio do interesse" (BARBERIS, 1996, p. 135) posto em marcha desde os Fragments - ou seja, o princípio, inspirado no constitucionalismo das revoluções americana e francesa, segundo o qual as constituições previnem o abuso de poder por meio da manipulação dos interesses dos agentes que comandam esses poderes. $\mathrm{O}$ fato de a posição do monarca ser simbolicamente construída como acima da condição ordinária dos cidadãos faz com que seu interesse não se alinhe ao de nenhum partido em disputa no plano da política ordinária, seu interesse se resumindo, então, à conservação da ordem e da liberdade.

É claro que a neutralidade do interesse do monarca só é assegurada se ele não exercer nenhum dos três poderes efetivos: o Executivo, o Legislativo e o Judiciário. $\mathrm{O}$ Executivo, ele o delega aos ministros, sem cuja assinatura nenhuma medida executiva do Rei é válida. O Legislativo é exercido pelas assembleias representativas, o veto do Rei entrando na lógica de contenção dos excessos legislativos (dentro da qual é preferível, argumenta Constant, a dissolução da assembleia e a convocação de novas eleições), não na de um Rei colegislador, como queriam Clermont-Tonnerre e os monarquianos. E o Judiciário é exercido por juízes inamovíveis. Como Maistre, Constant não quer um Rei ativo no exercício dos poderes. A elevação monárquica que ele prega, em sua crítica à Constituição de 1791, é uma elevação simbólica.

É na chave dessa elevação simbólica da realeza que se deve compreender a adesão de Constant a uma câmara hereditária ao lado da eletiva - algo inconcebível em seu período republicano, quando todas as instituições baseadas na hereditariedade eram rechaçadas. A partir das Réflexions, o autor considera que o prestígio e o poder simbólico de uma monarquia hereditária não podem ser mantidos sem o apoio de uma câmara legislativa igualmente hereditária, especialmente quando o princípio da igualdade se tornou a norma dominante nos âmbitos civil e social. Apenas a câmara hereditária teria um interesse real de defender a realeza hereditária e a magia que a cerca, impedindo-a de recorrer à força para garantir sua posição:

Para conferir a uma monarquia outros apoios além de soldados e carrascos, é preciso um corpo intermediário: Montesquieu o exige, mesmo na monarquia eletiva. Onde quer que vocês coloquem um único homem em tal grau de elevação, é necessário, se vocês quiserem dispensá-lo de estar sempre com o gládio na mão, cercá-lo de outros homens que tenham um interesse em defendê-lo (CONSTANT, 1814, p. 10). 
Por fim, assim como Maistre, Constant vê a faculdade de decisão discricionária em um círculo delimitado como um atributo da monarquia, sem o qual ela perderia toda a sua força simbólica e se veria diante da alternativa de se tornar despótica ou ser derrubada. Como vimos, a fórmula da "autoridade discricionária" é abandonada, provavelmente por precaução, mas o poder neutro monárquico continua possuindo os mesmos atributos discricionários que possuía o poder neutro republicano: o "Poder Judiciário dos outros poderes" continua agindo sem ser limitado pelas formas legais características do Judiciário. Além desse grau de "discricionariedade regulada" já justificado nos Fragments, a teoria constantiana da monarquia constitucional procura incorporar uma dose de discricionariedade vista como indissociável da dignidade de um Rei. Assim, por exemplo, Constant atribui ao monarca a escolha dos ministros, ao passo que, na Constituição republicana projetada nos Fragments, o Poder Executivo era eleito pelo Legislativo. Embora, em sua monarquia constitucional, o Poder Executivo seja distinto do poder régio, ele emana do poder régio, assim como o Poder Legislativo (também chamado de poder representativo) emana do povo (CONSTANT, 1814, p. 7). Nas Réflexions, abre-se até um espaço para o Rei ser concebido como estando na origem da soberania ao lado do povo, já que o autor se recusa a tratar da origem da soberania. ${ }^{119}$ Nos Principes de politique de 1815, reedita-se a tese de 1806 de uma soberania do povo limitada. ${ }^{120}$ De todo modo, aplica-se ao Rei da monarquia constitucional constantiana a norma erigida para o soberano de Maistre: é inútil tentar impedir sua vontade de querer arbitrariamente sobre o círculo de coisas posto à sua disposição (no caso da monarquia constitucional de Constant, a escolha e a demissão dos ministros, o veto, a dissolução da Câmara eletiva, a nomeação de novos pares, a concessão de graça e a comutação de

119 "Eu afastei essas discussões ociosas sobre a origem da soberania, discussões perigosas quando são inúteis, e que a força dos eventos sempre traz de volta quando, infelizmente, elas não o são" (CONSTANT, 1814, p. ix).

${ }^{120} \mathrm{Na}$ versão de 1818 das Réflexions, publicada no Cours de politique constitutionnelle, Constant explica assim a ausência de discussão sobre a soberania do povo em seu livro de 1814 e a presença dessa discussão em sua obra de 1815: "Em 1814, eu não tinha nenhuma razão para tratar do que se nomeou a soberania do povo, porque não havia o temor de que isso se tornasse, naquela ocasião, um pretexto para atentar contra nossas liberdades. Em 1815, era outra coisa. Bonaparte, que havia sempre reconhecido a soberania do povo em princípio, costumava tirar proveito dela para justificar o excesso de poder de que ele havia se apoderado, e que ele representava como lhe tendo sido delegado pelo próprio povo. Era, portanto, essa teoria que precisava ser atacada, a fim de quebrar essa arma perigosa nas mãos de um homem que já havia abusado demais dela" (CONSTANT, 2005d, II, p. 1161). 
penas). Tentar submeter essas decisões a algum princípio que limitasse seu caráter intrinsecamente discricionário seria se colocar em contradição com o princípio da inviolabilidade, que desobriga o Rei de se justificar de suas decisões. Como para Maistre, a limitação da monarquia consiste em traçar a fronteira a partir da qual sua vontade não pode mais decidir. Se, para o contrarrevolucionário inimigo de toda Constituição escrita, essa fronteira só podia ser informal, para Constant, o limite da vontade monárquica é bastante preciso: ela não pode exercer diretamente nenhum dos três poderes constitutivos do Estado, nem o Executivo, nem o Legislativo, nem o Judiciário. Reforça-se, assim, a ideia de uma decisão que não se confunde com as atividades governativa, legislativa nem judiciária. É essa decisão essencialmente discricionária a decisão política por excelência, e é a ela que Constant oferece a maior dignidade simbólica.

Desse modo, a imersão de Constant na tradição monarquista, a partir de 1814, lança novas bases para a faculdade de ação discricionária do poder neutro, as quais se somam aos raciocínios já desenvolvidos nos Fragments e relacionados nesta tese ao impacto do golpe do 18 Frutidor. Todavia, entre o Consulado e a Restauração, não ocorre apenas a conversão do autor à monarquia constitucional, mas também a virada liberal dos Principes de politique de 1806, por meio da qual, argumentamos no Capítulo 3, o arbítrio deixa de ser o atributo de um poder específico (o poder neutro), sendo colocado ao alcance de cada cidadão por meio de sua faculdade de julgamento moral das próprias leis. No presente capítulo, defendemos que a teoria da monarquia constitucional elaborada por Constant a partir de 1814 não acrescenta a seu arcabouço constitucional apenas a realeza, mas também esse imperativo de disseminar o arbítrio, na forma do julgamento moral autorizado a se rebelar contra as leis, entre diversas instâncias constitucionais, até colocálo, no limite, ao alcance de cada indivíduo. Como veremos nas seções seguintes, é na discussão sobre a responsabilidade dos ministros que o autor articula o arbítrio controlado do poder neutro monárquico com esse imperativo de disseminar o arbítrio entre diversas instâncias constitucionais, fazendo a sociedade como um todo (na escala de cada cidadão) participar da tarefa da decisão política.

\subsection{Responsabilidade dos ministros, um julgamento inevitavelmente arbitrário}


Publicado em fevereiro de 1815, De la responsabilité des ministres completa a teoria da monarquia constitucional anunciada por Constant nas Réflexions. Como vimos, o autor havia apresentado a distinção entre o poder neutro, incorporado pelo Rei inviolável, e o Poder Executivo, confiado a ministros responsáveis, como a chave de sua monarquia constitucional. Diante disso, é fácil presumir que o mecanismo perante o qual os detentores do Poder Executivo são responsáveis é uma variável fundamental para a definição da natureza do regime em questão.

Diferentemente do momento em que Constant escreve as Réflexions, De la responsabilité é escrito em uma situação em que a França já tem uma Constituição, a Carta de 1814, o desafio sendo agora interpretá-la. O artigo 55 da Carta havia estabelecido que "a Câmara dos Deputados tem o direito de acusar os ministros e os traduzir perante a Câmara dos Pares, a qual possui exclusivamente o direito de os julgar", e o artigo 56 completava que "eles só podem ser acusados por fato de traição ou concussão. Leis particulares especificarão essa natureza de delitos e determinarão as modalidades do processo" (GODECHOT; FAUPIN, 2018, p. 223). Como nota Rials (1987, p. 146), no quadro de uma monarquia limitada, não havia responsabilidade ministerial imaginável além da estritamente penal. Com efeito, os redatores da Carta de 1814 estavam longe de conceber o ministério como uma instância autônoma e politicamente responsável perante o Parlamento. De todo modo, a disposição de deixar a responsabilidade dos ministros para ser especificada por leis posteriores abria espaço para um debate sobre as modalidades práticas e a significação teórica da responsabilidade ministerial - um debate ao qual Constant se adianta no início de 1815.

O modo mais usual de analisar o debate da Restauração sobre a responsabilidade dos ministros, e particularmente a posição de Constant nesse debate, é pelo ângulo da maturação do regime parlamentar na França, entendido como o regime em que os ministros são politicamente (e não penalmente) responsáveis perante uma assembleia eleita (LAQUIÈZE, 2002, p. 4). O interesse mais comum entre os estudiosos que se dedicam à discussão de Constant sobre a responsabilidade dos ministros reside em entender até que ponto o autor vislumbrou um regime autenticamente parlamentar, apesar dos constrangimentos postos pelas disposições da Carta de 1814. Assim, para Kloocke, a obra de Constant constitui "o primeiro passo em direção ao parlamentarismo moderno" (KLOOCKE, 1984, p. 192). A atitude mais frequente, contudo, é ressaltar o modo impreciso e confuso com que os mecanismos parlamentaristas aparecem descritos na 
discussão do autor sobre a responsabilidade dos ministros, uma vez que a responsabilidade política se mistura à penal, e a dinâmica política entre ministros e maioria parlamentar não se desvincula totalmente da forma julgamento. Para autores como Rials (1987, p. 144-145), Rosanvallon (1994, p. 87) e Laquièze (2002, p. 151-162), os escritos de Constant sobre a responsabilidade dos ministros fazem parte de um longo processo de aprendizagem do parlamentarismo na França, mas o autor ainda se situa no início desse processo, estando longe de compreender de modo cristalino os mecanismos parlamentaristas e de apreender a responsabilidade política do ministério como fundamentalmente distinta da responsabilidade penal. Laquièze chega a sugerir que, na realidade, Constant compreendeu bem a responsabilidade puramente política dos ministros, cuja prática vinha se consolidando progressivamente na Inglaterra desde meados do século XVIII, mas procurou adaptar essa prática inglesa às condições diferentes da França da Restauração, "Estado menos avançado no caminho da monarquia liberal" (LAQUIÈZE, 2000, p. 175). Joaquín Varela Suanzes, por sua vez, argumenta que a teoria constantiana da responsabilidade dos ministros era completamente anacrônica em relação à prática política inglesa do início do século XIX: ao passo que o parlamentarismo já estava praticamente consolidado na Inglaterra, Constant teria erigido uma teoria em que o Rei exerce um papel ativo na nomeação e demissão dos ministros e em que as Câmaras não podem derrubar um ministério pelo simples voto de desconfiança. Dessa discrepância entre o modelo parlamentar inglês e o sistema de Constant, Suanzes conclui que, por um lado, o autor franco-suíço não tinha um conhecimento completo do sistema político britânico e que, por outro lado, o medo de uma democratização do Estado francês análoga à que havia ocorrido em 1793 levava o escritor a buscar fortalecer o poder régio como um "poder de reserva", capaz de "impedir o livre desenvolvimento da vontade popular quando esta pudesse chegar a pôr em perigo a ordem política e social estabelecida pelo liberalismo" (SUANZES, 1991, p. 137).

Jaume se destaca entre os intérpretes por propor "reconstituir primeiro a questão própria que Constant havia se colocado, nos próprios termos em que ele a considerou" (JAUME, 2000a, p. 228; JAUME, 2001, p. 416). Ao buscar situar a discussão de Constant sobre a responsabilidade dos ministros em sua problemática própria, o estudioso chega à conclusão de que o autor franco-suíço não estava "atrasado" em relação à responsabilidade parlamentar ulterior ou à prática inglesa, mas em um terreno teórico diferente. O problema teórico enfrentado por Constant seria o de como conciliar a 
intangibilidade do poder estatal herdado da antiga monarquia, formado em uma matriz teórica que atribuía ao soberano o direito de se pronunciar sobre o que é verdadeiro e justo, com a liberdade da nação e o espírito de livre exame característicos da sociedade pós-revolucionária (JAUME, 2000a, p. 233; JAUME, 2001, p. 422). Resultaria dessa tentativa de conciliação entre o Antigo Regime e o universo pós-revolucionário "uma tensão entre o horizonte de uma verdade em política (concepção objetivista) e a ideia do governo de opinião (concepção pluralista e, se quisermos, subjetiva)" (JAUME, 2000a, p. 239; JAUME, 2001, p. 428-429; ênfase do autor).

Nós seguimos a orientação de Jaume, ao procurar analisar a discussão de Constant sobre a responsabilidade dos ministros por um ângulo distinto do de sua posição no processo de aprendizagem do regime parlamentar pelos franceses. Como Jaume, o que nos interessa é o problema particular enfrentado por Constant, nos termos postos pelo autor, não o estágio mais ou menos avançado em que ele se encontrava na compreensão do regime posteriormente chamado de parlamentar. Em outras palavras, a teoria moderna do parlamentarismo não constituirá para nós o critério de avaliação da elaboração de Constant sobre a responsabilidade dos ministros. A causa fundamental é o caráter anacrônico desse critério de avaliação. Há divergências sobre o grau em que a França da Restauração e da Monarquia de Julho vivenciou um regime verdadeiramente parlamentar, assim como sobre quais teriam sido os momentos crucias de "parlamentarização" do regime (cf. LAQUIÈZE, 2002, p. 6-24). De todo modo, é relativamente consensual que essa ainda não era a discussão na Primeira Restauração, quando Constant elabora sua teoria da responsabilidade dos ministros. Como veremos na próxima seção, é a experiência da Chambre introuvable que enseja uma confrontação entre interpretações da Carta de 1814 que hoje podemos chamar, com certo anacronismo controlado, de parlamentaristas e antiparlamentaristas. Porém, esse debate do início da Segunda Restauração é posterior à elaboração de Constant e, procuraremos demonstrar na próxima seção, não respondia aos mesmos problemas teóricos e políticos de nosso autor, ressaltando antes sua particularidade do que seu papel de precursor do parlamentarismo.

Por outro lado, o problema teórico enfrentado por Constant a ser ressaltado aqui não é o mesmo que propõe Jaume. Em nossa interpretação, o autor não queria conservar um soberano guardião da Verdade e da Justiça no interior de um universo liberal. Constant tinha uma verdadeira aversão às concepções que atribuíam à autoridade política a missão de levar os indivíduos à verdade, como ressalta o próprio Jaume, em outras passagens 
(JAUME, 1997, p. 64-72). O problema teórico enfrentado pelo autor em sua discussão sobre a responsabilidade dos ministros era, segundo esta tese, a incorporação do inevitável arbítrio ao sistema político, não mais pelo paradigma da concentração desse arbítrio em um poder estatal específico (o poder neutro), mas pelo paradigma da difusão do arbítrio no conjunto do edifício constitucional. Desse modo, ele busca uma espécie de tradução institucional da disseminação do arbítrio que nós procuramos mostrar, no Capítulo 3 desta tese, estar presente nos Principes de politique de 1806, por meio do poder que têm jurados, detentores do direito de graça e, no limite, indivíduos comuns de decidir discricionariamente sobre a insuficiência ou ilegitimidade das leis. Como veremos, no caso da responsabilidade dos ministros, não está tanto em questão a ilegitimidade da lei, mas sua insuficiência para determinar os delitos que só podem ser chamados assim em função de uma contingência política, a qual define também qual é a "punição" cabível para o "delito" contingente em questão. Vamos ao texto de Constant.

Seu primeiro movimento consiste em determinar a esfera de aplicação da responsabilidade ministerial. Para o autor, ela não se aplica sobre os atos ilegais dos ministros, mas "sobre o mau uso do poder que a lei confere, e sobre os atos que ela autoriza" (CONSTANT, 2001, I, p. 441). Rials (1987, p. 144) nota que, nesse ponto específico, Constant avança para uma compreensão da responsabilidade política dos ministros distinta da penal. Com efeito, para o autor, a responsabilidade ministerial não se aplica aos crimes definidos por lei, pelos quais os ministros devem responder como cidadãos comuns perante os tribunais ordinários, não como ministros perante o Parlamento (CONSTANT, 2001, I, p. 442).

Para compatibilizar sua interpretação da responsabilidade dos ministros com o artigo 56 da Carta de 1814, que, como visto acima, autoriza a acusação dos ministros apenas para os casos de traição e concussão, Constant recorre a uma argumentação um tanto artificial (JAUME, 2001, p. 429). Ele argumenta que a Carta limitou a responsabilidade a esses dois crimes porque "eles são os dois únicos pelos quais os ministros podem prevaricar como ministros, ou seja, fazendo mau uso do poder que a lei lhes transmitiu" (CONSTANT, 2001, I, p. 445). Assim, ele procura compreender a traição e a concussão por um paradigma político, mais do que criminal: a traição diria respeito a fenômenos como a má condução da guerra ou das relações exteriores, e a concussão, ao mau uso dos recursos públicos (CONSTANT, 2001, I, p. 445). Quando suspeitos de crime 
no sentido estrito (não político), os ministros deveriam ser acusados perante tribunais ordinários e responder como cidadãos comuns.

Desse modo, Constant nega a imunidade dos ministros para crimes comuns, implícita na disposição da Carta que só permitia o julgamento dos ministros nos casos de traição e concussão. As consequências mais interessantes desse movimento do autor são as que ele extrai para os agentes subalternos do ministério, os quais, em sua visão, também devem responder à justiça comum pela acusação de atos ilegais. As consequências são interessantes porque Constant se vê forçado a responder à objeção segundo a qual, ao tornar os agentes inferiores responsáveis por seus atos perante os tribunais, ele estaria enfraquecendo a disposição desses agentes a obedecer passivamente às ordens dos ministros, incentivando-os a julgar as medidas ordenadas pelos superiores antes de executá-las (CONSTANT, 2001, I, p. 449). O autor aproveita essa objeção para retomar suas considerações contra a "obediência implícita e passiva" (CONSTANT, 2001, I, p. 449), pregando o espírito de exame nos agentes subordinados, até mesmo no exército. Para ele, esse espírito de exame é a única garantia contra a tirania, sem a qual os governos despóticos contam com um exército de cidadãos dóceis prontos a oprimir os demais cidadãos quando recebem ordens para isso. Constant deixa clara a relação desse raciocínio com a defesa de que os indivíduos julguem as leis antes de obedecê-las, realizada nos Principes de politique de 1806 e tratada no Capítulo 3 desta tese, mas prefere não se desviar demais do tema da responsabilidade ministerial: "Eu poderia tirar desses princípios consequências gerais de grande importância sobre a obediência que os cidadãos devem às próprias leis; mas eu não quero me desviar de meu assunto" (CONSTANT, 2001, I, p. 452).

O ponto mais sério da objeção a que Constant tenta responder é a "dolorosa incerteza" sofrida pelos agentes subalternos ao deixarem de ser "autômatos zelosos" e se tornarem agentes morais responsáveis por sua decisão de obedecer ou não às ordens dos superiores, podendo ser punidos pela execução de um ato ordenado (CONSTANT, 2001, I, p. 452). O remédio oferecido pelo autor para aplacar essa "dolorosa incerteza" é o julgamento por jurados. Constant retoma, assim, a noção (antibeccariana) desenvolvida nos Principes de politique de 1806, e analisada no Capítulo 3 desta tese, dos jurados como intérpretes de uma razão comum autorizada a julgar os casos em que a simples aplicação da lei escrita seria insuficiente, podendo mesmo levar a erros: 
(...) quando é preciso decidir se tal agente subordinado a um ministro, e que lhe prestou ou recusou obediência, agiu bem ou mal, a lei escrita é completamente insuficiente. É, mais uma vez, a razão comum que deve se pronunciar. É, portanto, necessário recorrer, neste caso, a jurados, seus únicos intérpretes. Somente eles podem avaliar os motivos que dirigiram esses agentes, e o grau de inocência, de mérito ou de culpabilidade de sua resistência ou de sua colaboração (CONSTANT, 2001, I, p. 453; ênfase nossa).

No Capítulo 3, nós relacionamos essa faculdade de os jurados decidirem sobre a insuficiência da lei escrita à incorporação política do arbítrio por parte de Constant. Se essa relação com o tema do arbítrio podia causar alguma dúvida na análise dos Principes de politique de 1806, não é mais o caso em De la responsabilité, em que o arbítrio atribuído aos jurados é não somente explicitado, mas ainda relacionado ao grau de discricionariedade intrínseco à incerteza dos negócios humanos:

Uma reflexão me vem. Dirão que eu coloco o arbítrio nos jurados. Mas vocês o colocam nos ministros. É impossível, repito, regulamentar tudo, escrever tudo e fazer da vida e das relações dos homens entre eles uma ata redigida de antemão, na qual apenas os nomes permanecem em branco, e que dispensa, a partir de sua redação, as gerações que se sucedem de todo exame, de todo pensamento, de todo recurso à inteligência. Ora, se, independentemente do que fizermos, resta sempre, nos negócios humanos, algo de discricionário, eu pergunto: não é melhor que o exercício do poder que essa porção discricionária exige seja confiado a homens que só o exercem em uma única circunstância; que não se corrompem nem se cegam pelo hábito da autoridade; e que são igualmente interessados na liberdade e na boa ordem, do que a homens que têm por interesse permanente suas prerrogativas particulares? (CONSTANT, 2001, I, p. 454; ênfases nossas). ${ }^{121}$

Assim, logo nos primeiros capítulos de De la responsabilité (a análise até aqui acompanhou o argumento dos quatro primeiros capítulos da obra), Constant deriva da não imunidade penal dos ministros a necessidade de disseminar o arbítrio pelo edifício constitucional. Como os agentes subalternos também são desprovidos de imunidade penal, eles devem recorrer a seu julgamento individual para examinar se as ordens apresentadas pelos superiores devem ser cumpridas ou não. Caso o cumprimento ou descumprimento de uma ordem leve algum desses agentes a julgamento, este deve ser realizado por jurados que não aplicam simplesmente a letra da lei, mas exercem a porção discricionária de poder que a incerteza dos negócios humanos exige, utilizando a razão comum para avaliar as motivações morais do agente inferior em questão. Embora o arbítrio seja utilizado aqui para se referir às decisões de funções específicas (agentes subalternos e jurados), o argumento de Constant tem por alvo o indivíduo universal, uma vez que o ponto essencial é a necessidade de todo indivíduo realizar um julgamento moral

${ }^{121}$ Nota-se nessa citação a equivalência conceitual estabelecida entre arbitraire e discrétionnaire, já ressaltada em outras passagens de Constant ao longo desta tese. 
antes de obedecer a uma ordem de um superior. Quanto aos jurados, não se trata de um órgão à parte da sociedade, mas dos próprios cidadãos comuns reunidos pontualmente para realizar um julgamento, cada indivíduo podendo se encontrar eventualmente nessa situação. Portanto, a disseminação do arbítrio realizada por Constant tem o objetivo de atingir a escala de cada indivíduo particular.

No Capítulo 6 (“De la responsabilité proprement dite"), Constant abandona sua reflexão sobre os agentes subalternos e retorna ao tema principal de seu livro, a responsabilidade específica dos ministros perante o Parlamento. Como vimos, essa responsabilidade não diz respeito aos crimes cometidos pelos ministros, pelos quais eles devem responder nos tribunais ordinários, mas ao mau uso de um poder legal (CONSTANT, 2001, I, p. 460). Essa definição política da responsabilidade leva o autor a apontar o caráter ilusório de "qualquer tentativa de redigir, sobre a responsabilidade, uma lei precisa e detalhada, como devem ser as leis criminais" (CONSTANT, 2001, I, p. 460). Afinal, há inúmeras maneiras de realizar um mau uso do poder que a lei confere aos ministros, e seria vão tentar definir pela lei os infinitos modos com que os ministros podem prejudicar a nação utilizando suas atribuições legais. Logo, os ministros devem ser julgados pelas Câmaras sem leis precisas que embasem esse julgamento. Ora, vimos que a ausência de leis precisas caracteriza, para Constant, o... arbítrio. Com efeito, o autor se apressa em reconhecer o caráter arbitrário do julgamento político a que os ministros precisam estar sujeitos, relacionando esse arbítrio ao caráter intrinsecamente contingente da política:

\footnotetext{
Considerarão, talvez, que eu coloco os ministros em uma situação extremamente desfavorável e perigosa. Ao passo que eu exijo, para os simples cidadãos, a salvaguarda da precisão mais exata e a garantia da letra da lei, eu entrego os ministros a uma espécie de arbítrio exercido sobre eles, tanto por seus acusadores como por seus juízes. Mas esse arbitrio está na essência mesma da coisa. Veremos que seus inconvenientes serão temperados pela solenidade das formas, pelo caráter augusto dos juízes e pela moderação das penas. Aqui, o princípio deve ser estabelecido: e penso que é melhor admitir na teoria o que não pode ser evitado na prática (CONSTANT, 2001, I, p. 461; ênfases nossas).
}

Esta passagem é fundamental para a tese aqui desenvolvida. Se a letra exata da lei é vista como uma garantia fundamental da liberdade do cidadão comum, Constant reconhece explicitamente a insuficiência da lei para regrar as contingências da vida 
política, rompendo com toda a tradição do legicentrismo revolucionário. ${ }^{122}$ Diante dessa insuficiência política da lei (somada à insuficiência sobretudo moral explorada no Capítulo 3 desta tese), o autor se vê forçado a incorporar o arbítrio à vida política. Mais do que incorporação, trata-se do reconhecimento do caráter inexpugnável do arbítrio na política, já que esse arbítrio "está na essência mesma da coisa". Arbítrio controlado bem entendido, e temperado "pela solenidade das formas, pelo caráter augusto dos juízes e pela moderação das penas" - garantias que serão tratadas na sequência do livro. Todavia, essa domesticação do arbítrio não deve eclipsar o reconhecimento de sua inevitabilidade. É interessante observar Constant afirmando que é sempre melhor admitir na teoria o que não se pode evitar na prática. Segundo a tese aqui defendida, essa postura mais "pragmática" frente ao inevitável arbítrio é a principal lição que o autor tirou da prova do 18 Frutidor. Como no caso do poder neutro desenvolvido nos Fragments, trata-se de incorporar controladamente o arbítrio para impedir que sua realização necessária, sendo bloqueada pela Constituição, não se efetive pela forma do golpe de Estado e da ruptura institucional:

Um ministro pode fazer tanto mal, sem se desviar da letra de nenhuma lei positiva, que, se vocês não prepararem meios constitucionais de reprimir esse mal e punir ou afastar o culpado (pois eu mostrarei que se trata muito mais de retirar o poder dos ministros prevaricadores do que de puni-los), a necessidade fará esses meios serem encontrados fora da Constituição (CONSTANT, 2001, I, p. 461).

Em De la responsabilité, Constant é tão preocupado em enfatizar o caráter inexpugnável do arbítrio na política, que ele utiliza o próprio termo arbitraire para se referir à natureza da responsabilidade ministerial, alternando esse termo com discrétionnaire, ${ }^{123}$ em vez de utilizar apenas o segundo termo, mais neutro, como nos Fragments. A alternância dos termos indica mais uma vez a equivalência conceitual das duas palavras para Constant.

${ }^{122}$ Nessa ruptura com o legicentrismo revolucionário, Constant se aproxima de Necker, que já havia, em seu projeto de Constituição republicana, como vimos no Capítulo 2 desta tese, considerado a responsabilidade do Poder Executivo perante o Legislativo como um processo necessariamente arbitrário (cf. p. 135-136 supra).

${ }^{123}$ Por exemplo, na passagem seguinte: “A lei sobre a responsabilidade não poderia ser precisa nem detalhada, como as leis comuns. Trata-se de uma lei política, cuja natureza e aplicação têm inevitavelmente algo de discricionário" (CONSTANT, 2001, I, p. 466; ênfase nossa). 
Uma vez reconhecido o caráter arbitrário ou discricionário da responsabilidade ministerial, resta determinar as modalidades de realização desse inevitável arbítrio. É importante notar que Constant não abre mão, para a realização dessa responsabilidade ministerial arbitrária, da forma do julgamento político. É nisso que o autor se afasta de qualquer teoria moderna do parlamentarismo. É verdade que algumas considerações de Constant aproximam seu modelo político daquilo que se convencionou chamar de regime parlamentar, e, neste sentido, é compreensível que a maioria dos comentadores analise sua teoria da responsabilidade dos ministros à luz da evolução do parlamentarismo na França. Assim o autor desejava, no início de 1815, que as instituições da monarquia constitucional evoluíssem na França:

Quando tivermos o que ainda não temos, mas que é indispensável em toda monarquia constitucional, quero dizer, um ministério que age em concerto, uma maioria estável e uma oposição bem separada dessa maioria, nenhum ministro poderá se manter se não tiver para si o maior número de votos, a não ser que se convoque o povo por novas eleições (CONSTANT, 2001, I, p. 463).

Um Parlamento bem dividido entre maioria e oposição, um ministério unificado e alinhado à maioria parlamentar, o recurso a novas eleições quando o alinhamento entre ministério e maioria parlamentar é rompido: eis os elementos do modelo político de Constant que o aproximam daquilo que será chamado de regime parlamentar. Apesar desses elementos, reafirmamos a inadequação, do ponto de vista desta tese, de analisar a teoria constantiana da responsabilidade dos ministros à luz do processo de aclimatação do parlamentarismo na França. A razão é que não era esse o problema a que a teoria em questão buscava responder. O problema sobre o qual Constant se debruçava não era o das relações adequadas entre ministério e maioria parlamentar, embora o autor tivesse preferências normativas sobre como deveriam ser essas relações. O problema era antes o de como realizar um julgamento necessariamente arbitrário, toda vez que um ministro tivesse uma conduta que a contingência política (e não leis escritas prévias) viesse a considerar como uma espécie de delito político. Assim, como vimos, a forma julgamento é intrínseca ao problema teórico em questão, o qual não pode ser resolvido pelos elementos parlamentaristas presentes na visão de Constant sobre o bom funcionamento da monarquia constitucional. É insuficiente afirmar, como a maioria dos comentadores, que Constant ainda estava no início do longo processo de aprendizagem do regime parlamentar, misturando a responsabilidade política dos ministros à responsabilidade penal. É igualmente inadequado sugerir que se tratava de uma adaptação do parlamentarismo inglês às condições menos avançadas da França da Restauração, como 
sugere Laquièze (2000, p. 175), ou de uma contenção dos efeitos assustadoramente democratizantes do sistema político britânico, como sugere Suanzes (1991, p. 136-138). $\mathrm{Na}$ interpretação aqui desenvolvida, Constant não mantém as formas do julgamento penal apenas porque o regime parlamentar ainda estava no início de seu processo de desenvolvimento, ou porque ele estava menos avançado na França do que na Inglaterra, ou ainda porque o autor temia que o parlamentarismo puro pudesse levar a uma democratização radical do sistema político análoga à de 1793. As formas do julgamento penal são mantidas porque a ideia de um julgamento necessariamente arbitrário era o próprio problema teórico a ser resolvido, Constant buscando mais uma vez incorporar e temperar os efeitos do inevitável arbítrio.

É com esse espírito que o autor recusa o direito de as assembleias representativas declararem os ministros indignos da confiança pública, uma ideia aventada no debate da Primeira Restauração sobre a responsabilidade dos ministros (CONSTANT, 2001, I, p. 463). A principal inspiração dessa proposta era a motion of censure ou vote of no confidence que vinha se institucionalizando na Inglaterra desde meados do século XVIII, tornando-se ao longo do tempo mais praticada do que o impeachment, o processo políticopenal que Constant adota por modelo (SUANZES, 1991, p. 132). O principal argumento do autor franco-suíço para recusar a ideia de um voto de desconfiança - a qual tornaria praticamente automática a queda dos ministros que entram em conflito com a maioria parlamentar - é justamente a necessidade que ele vê de um tribunal para julgar os supostos crimes políticos do ministro. "Esse tribunal, por seu julgamento, qualquer que seja ele, restabelece a harmonia entre o governo e os órgãos do povo" (CONSTANT, 2001, I, p. 463-464). Como aprofundaremos na próxima sessão, Constant se distingue das interpretações da Carta de 1814 que buscam submeter o processo político a princípios fixos, sejam eles parlamentaristas ou antiparlamentaristas. Se um conflito se estabelece entre o Parlamento e um ministro, não há um princípio fixo capaz de decidir que saída dar para essa contenda. Um tribunal deve ser formado para julgar arbitrariamente a questão e tentar restabelecer a harmonia entre o governo e os órgãos do povo.

Além disso, o direito de as assembleias excluírem um ministro assim que o desejarem, sem nenhum julgamento, implicaria na prática um poder de as câmaras nomearem os ministros, o que Constant vê como um atentado a uma das prerrogativas do Rei (CONSTANT, 2001, I, p. 464). Como vimos na seção anterior, a nomeação e a demissão dos ministros são concebidas pelo autor como fazendo parte dos atributos 
discricionários da realeza, inseparáveis de sua dignidade simbólica, condição para o bom exercício do poder neutro.

Assim, Constant se afasta do espírito da Carta de 1814 ao estender a responsabilidade ministerial a uma noção alargada de crimes políticos, compreendidos como usos nocivos do poder legal conferido aos ministros, ao passo que a Carta procurava restringir essa responsabilidade aos altos crimes de traição e concussão. Porém, o autor se aproxima do espírito da Carta ao compreender a responsabilidade dos ministros como um julgamento realizado pela Câmara dos Pares, a partir de uma acusação levada a cabo pela Câmara dos Deputados.

Sobre a acusação realizada pela Câmara Baixa, a principal preocupação de Constant é garantir sua publicidade, refutando os argumentos dos que defendem os segredos de Estado, dos que temem pela honra dos ministros e dos que consideram perigoso agitar a opinião pública com acusações contra o governo (CONSTANT, 2001, I, p. 469-472). O ponto é fundamental, pois, como veremos adiante, o objetivo mesmo da responsabilidade dos ministros, tal como concebida por Constant, é a agitação da opinião pública, despertando na sociedade um espírito de exame crítico dos atos do governo. Essa tarefa de examinar criticamente os atos do governo, o autor a atribui a cada cidadão, visto que a acusação política contra um ministro pode ter seu ponto de partida em petições individuais encaminhadas à Câmara dos Deputados, embora essas petições só adquiram um valor legal ao serem examinadas e sancionadas pela Câmara (CONSTANT, 2001, I, p. 469).

Constant atribui ainda à Câmara dos Deputados o prosseguimento da acusação, utilizando o argumento de que as causas da responsabilidade ministerial são políticas mais do que judiciais, a fim de criticar a ideia de uma espécie de procurador-geral encarregado de dar prosseguimento às acusações contra os ministros. Acusações políticas devem ser conduzidas em sua totalidade por políticos, não por procuradores "que estudaram apenas os códigos de leis positivas, e limitados, por seus deveres habituais, a requerer apenas a aplicação estrita dessas leis" (CONSTANT, 2001, I, p. 475).

Quanto ao tribunal encarregado de julgar as acusações políticas contra os ministros, a preocupação de Constant é garantir "que ele fará seu poder mais ou menos discricionário servir para a avaliação equitativa não somente dos atos, mas também dos motivos" (CONSTANT, 2001, I, p. 466). Como no caso do julgamento dos agentes 
subalternos, discutido no início da obra, trata-se aqui de garantir um julgamento marcado pela latitude moral, o qual não se contentará com uma simples aplicação da lei, mas buscará fazer uma avaliação de conjunto da conduta do ministro em questão, dos motivos e dos resultados de sua ação. Como vimos no Capítulo 3 desta tese e na discussão sobre os agentes subalternos, essa latitude moral é o principal atributo que o autor confere à instituição do júri, considerada como uma instituição capaz de impedir a aplicação cega da lei, por meio de um julgamento moral colocado entre a lei e sua execução. Ora, Constant deseja, para o julgamento das acusações políticas contra os ministros, uma instituição equivalente ao júri nesse sentido: “Com uma razão ainda mais forte, precisase, para julgar os ministros, em questões ainda mais difíceis, e sobre as quais a lei positiva pode menos ainda pronunciar com precisão, de uma instituição que participe das vantagens dos jurados" (CONSTANT, 2001, I, p. 466).

Todavia, se os jurados são excelentes para julgar com latitude moral as acusações contra um indivíduo, a questão se torna mais complicada quando se trata de um julgamento eminentemente político. Assim, "simples jurados seriam insuficientes, quando se trata de uma responsabilidade que se aplica aos maiores problemas políticos, aos interesses ao mesmo tempo mais vastos e mais secretos da nação" (CONSTANT, 2001, I, p. 467). O mesmo raciocínio da acusação vale para o julgamento propriamente dito: um julgamento político não poderia ser realizado senão por um corpo político. Entretanto, a mesma Câmara dos Deputados que acusa não poderia também julgar, inclusive porque a dependência dos deputados em relação ao povo os torna muitas vezes inimigos dos ministros. Compreendendo a acusação dos ministros como "um processo entre o Poder Executivo e o poder do povo" (CONSTANT, 2001, I, p. 467), Constant busca uma autoridade neutra entre o governo e o povo para realizar esse julgamento, repetindo o raciocínio que o levou à ideia de poder neutro nos Fragments. Em De la responsabilité, a autoridade neutra não é mais nem a assembleia eleita e vitalícia dos Fragments, nem o Rei de sua teoria da monarquia constitucional, mas a Câmara dos Pares. Separados do povo por seus privilégios, mas não fazendo parte do governo, e perdendo sua posição tanto no caso de uma derrubada do governo como no de uma supressão despótica da liberdade, os pares teriam um interesse distinto daqueles do povo e do governo, estando aptos a resolver a controvérsia entre as duas partes. "A Câmara dos Pares é, portanto, pela independência e pela neutralidade que a caracterizam, o juiz 
conveniente dos ministros, para todos os delitos que entram na esfera da responsabilidade" (CONSTANT, 2001, I, p. 467).

O autor se alinha, assim, ao que já estava disposto na Carta de 1814. No entanto, a novidade de sua argumentação consiste na insistência de que os pares realizem um julgamento discricionário análogo a sua visão dos jurados. No caso dos jurados, a inflexibilidade da lei é contornada pela razão comum, capaz de colocar o sentimento e a empatia acima da letra rígida da lei. No caso dos pares, Constant ressalta sua eminente função política e sua elevada posição social. A primeira os torna familiares dos grandes interesses do Estado e aptos a julgar politicamente as ações dos ministros. A segunda lhes imprime "uma gravidade de caráter que lhes ordena a maturidade do exame e uma afabilidade de costumes que, dispondo-os aos cuidados e às considerações, compensa a lei positiva pelos escrúpulos delicados da equidade" (CONSTANT, 2001, I, p. 468). Percebe-se que, em seu elogio do arbítrio capaz de preencher as insuficiências da lei, Constant utiliza tanto argumentos democráticos (o elogio da razão do cidadão comum que, tirado do seio do povo, exerce a função de jurado) como aristocráticos (a apologia das virtudes intrínsecas à posição social elevada dos pares). Os comentadores atuais simpáticos a Constant tendem a enfatizar os aspectos democráticos de sua teoria, ao passo que seus críticos contemporâneos costumam olhar exclusivamente para a dimensão aristocrática de seu pensamento. Do ponto de vista desta tese, interessa sublinhar o argumento da insuficiência da lei e a necessidade de preencher essa insuficiência por um julgamento discricionário. Tanto o senso moral do cidadão comum como a posição social elevada dos pares podem ser apresentados como credenciais para a realização desse julgamento discricionário, dependendo do contexto tratado pelo autor.

Constant acrescenta ainda que "a natureza da lei sobre a responsabilidade implica a necessidade de investir os juízes do direito de aplicar e mesmo de escolher a pena" (CONSTANT, 2001, I, p. 476; ênfase nossa), enfatizando que o caráter político da responsabilidade torna impossível estabelecer leis precisas que determinem exatamente a punição para cada delito (como sonhava o iluminismo penal tratado no Capítulo 3 desta tese). "A única consciência dos pares" (CONSTANT, 2001, I, p. 476) deve decidir arbitrariamente a pena apropriada para o ministro em questão, a lei se limitando a elencar as três punições possíveis: “a morte, o exílio e a detenção” (CONSTANT, 2001, I, p. 476).

Por fim, o autor insiste no direito de graça conferido pela Carta ao Rei, refutando os parlamentares que defendem proibir a aplicação do direito de graça aos casos de 
condenação de ministros. Já vimos, no Capítulo 3, a importância que Constant atribui ao direito de graça como um modo de contornar a aplicação inflexível da lei, a qual pode ser justa em geral, mas injusta em sua aplicação rigorosa a um caso particular. Em De la responsabilité, trata-se de defender o direito de graça ilimitado em sua qualidade de prerrogativa intrínseca à realeza, em uma argumentação que lembra Necker. Qualquer limitação dessa prerrogativa implicaria dissolver a magia simbólica da realeza tratada na Seção 4.1. Constant relembra a inviolabilidade do monarca como primeiro princípio da monarquia constitucional, e afirma que essa inviolabilidade repousa sobre a ficção legal de que o Rei não pode fazer nenhum mal. ${ }^{124} \mathrm{O}$ autor enfatiza o caráter fictício dessa suposição, pois o monarca é um homem sujeito às mesmas paixões e fraquezas dos demais seres humanos, podendo ordenar a um ministro ações iníquas, prometendo-lhe a graça em caso de condenação. Contudo, essa ficção legal é necessária, pois, sem ela, não haveria inviolabilidade, o povo poderia acusar e julgar o Rei, e não haveria mais monarquia constitucional (CONSTANT, 2001, I, p. 478-479). Como vimos na seção anterior, Constant define a realeza pelos mesmos critérios de Maistre: inviolabilidade, supremacia simbólica e poder de querer invencivelmente em sua área de atuação legítima. Uma vez conferido ao Rei o direito de graça, é impossível limitar essa prerrogativa sem derrubar, na prática, a monarquia. Portanto, a imersão de Constant na tradição monarquista a partir de 1814, tratada na seção anterior, introduz mais uma dose de arbítrio ao julgamento, já arbitrário, dos ministros.

Mas, e se ocorrer a hipótese, considerada plausível por Constant, de o Rei ordenar a um ministro uma ação iníqua, prometendo-lhe a impunidade garantida pelo direito de graça? Para o autor, o mecanismo de responsabilidade ministerial descrito por ele responde adequadamente a esse perigo, mesmo se o ministro culpado receber o indulto

\footnotetext{
${ }^{124}$ Constant se inspira no axioma da Common Law inglesa segundo o qual "the King can no do wrong”, um axioma seguido pela convenção de que "the King cannot act alone" (SUANZES, 1991, p. 135). $\mathrm{Na}$ Inglaterra, esses dois axiomas acabaram sendo interpretados no sentido de proibir toda ação que partisse exclusivamente do monarca - inclusive a concessão de graça a um ministro condenado pelo Parlamento, proibida pelo Decreto de Estabelecimento de 1701 (SUANZES, 1991, p. 131-132). Constant, por sua vez, entende que a ficção segundo a qual o Rei não pode errar só pode ser conservada mediante o afastamento do monarca em relação ao exercício direto dos poderes Executivo, Legislativo e Judiciário, mas também mediante a ausência de limitação do exercício das prerrogativas atribuídas ao Rei, as quais incluem o direito de graça, o de nomeação e demissão dos ministros, o de nomeação dos pares, o de dissolução da Câmara dos Deputados e o de veto das leis.
} 
do Rei. Afinal, o mais importante não é a punição do ministro, mas seu afastamento das funções governamentais, e esse afastamento é garantido pela acusação dos deputados e pelo julgamento dos pares: pois o ministro "não pode nem continuar a governar o Estado com uma maioria que o acusa, nem se criar, por novas eleições, uma nova maioria, porque, nessas eleições, a opinião popular reconduziria ao seio da assembleia a maioria acusadora" (CONSTANT, 2001, I, p. 480).

O autor chega, assim, ao objetivo último do mecanismo de responsabilidade ministerial descrito por ele, o qual não é a punição dos ministros na medida exata dos crimes que eles cometeram. É admitido que, pelas disposições desenvolvidas, "os ministros serão denunciados frequentemente, acusados às vezes, condenados raramente, punidos quase nunca" (CONSTANT, 2001, I, p. 481). Isso não teria nenhum problema do ponto de vista da repressão ao crime, pois, em se tratando de delitos políticos, "o crime e a inocência são raramente de uma evidência completa" (CONSTANT, 2001, I, p. 481). Os dois objetivos da responsabilidade dos ministros são enunciados de modo muito claro:

A responsabilidade me parece dever atingir sobretudo dois objetivos: o de retirar o poder dos ministros culpados; e o de fomentar na nação, pela vigilância de seus representantes, pela publicidade de seus debates e pelo exercício da liberdade de imprensa, aplicado à análise de todos os atos ministeriais, um espírito de exame, um interesse habitual na manutenção da Constituição do Estado, uma participação constante nos negócios, em poucas palavras, um sentimento animado de vida política (CONSTANT, 2001, I, p. 481).

Contrariando toda uma interpretação vulgar de Constant ainda influente (embora cada vez menos), segundo a qual o autor faria a apologia do desengajamento político e do enclausuramento do indivíduo no domínio privado, sua preocupação principal, explicitada na citação acima, reside na sustentação de uma vida política animada, definida pelo interesse habitual de todos os indivíduos pela conservação da Constituição e pela participação constante dos cidadãos nos negócios públicos, por mecanismos diversos como a imprensa, petições, manifestações, acompanhamento dos debates, etc. A responsabilidade dos ministros não teria nenhum valor por si só, como mecanismo institucional, se, por meio da mobilização da opinião pública, não envolvesse a sociedade como um todo, na escala de cada indivíduo convocado a exercer seu espírito de exame. Esse raciocínio pode ser remetido ao que Jaume considera ser a grande ideia do grupo de Coppet: "não pode haver instituições livres sem o enraizamento destas últimas no indivíduo" (JAUME, 2000b, p. 225). 
No caso da responsabilidade dos ministros, a integração entre instituições livres e indivíduos críticos ocorre por meio de um complexo processo de disseminação do arbítrio, no qual o poder neutro monárquico é apenas um dos sujeitos a exercer seu poder de decisão discricionária. Todo o processo é marcado pelo arbítrio, como lembra Constant em inúmeras passagens, na medida em que, tratando-se de um julgamento político, toda lei precisa seria deslocada: a Câmara dos Deputados acusa o ministro de acordo com uma correlação de forças política, a Câmara dos Pares o julga utilizando uma latitude moral característica dos jurados, e o Rei tem a prerrogativa de anular a condenação segundo as preferências de seu coração. Tudo isso com o objetivo de que os cidadãos como um todo acompanhem o processo e desenvolvam um espírito de exame que os permita, em circunstâncias definidas por eles próprios, contrapor-se (discricionariamente) à lei estabelecida. Além disso, os agentes subordinados devem recorrer a esse mesmo espírito de exame para decidir se executam ou não as ordens de seus superiores. Se essa decisão os leva a um julgamento, este deve ser realizado por jurados que não aplicam uma lei precisa, mas recorrem ao mesmo espírito de exame para decidir discricionariamente se houve crime ou não, e qual é a pena cabível.

A discussão sobre a responsabilidade dos ministros é uma boa ocasião para Constant afirmar sua convicção sobre o caráter inexpugnável do arbítrio na vida política, fazendo um contraste entre o julgamento político e o julgamento de cidadãos comuns. Com efeito, na visão do autor, os indivíduos comuns e os ministros estabelecem pactos diferentes com a sociedade. Para o cidadão comum, nenhum julgamento que não segue a letra exata da lei poderia ser legítimo, todo arbítrio devendo ser proibido de modo absoluto. Mas a mesma cláusula não está prevista no pacto que os ministros fazem com a sociedade. Ao aceitar os postos políticos eminentes que eles desejam ocupar, eles consentem em ser julgados pelo "conjunto da obra" de sua política, o que só pode ocorrer de modo arbitrário, pois as leis precisas só permitem ou proíbem ações pontuais (CONSTANT, 2001, I, p. 481-482). Apesar dessa argumentação pela inevitabilidade do arbítrio, o autor sublinha que "o arbítrio é, em qualquer circunstância, um grave inconveniente" (CONSTANT, 2001, I, p. 481). Por isso, o arbítrio a que os ministros estão sujeitos é temperado pelo julgamento pelos pares, isentos de paixões populares, e pela possibilidade de receber o indulto do Rei - "recurso assegurado a todos os súditos, mas mais favorável aos ministros do que a qualquer outro, em função de sua posição e de suas relações pessoais" (CONSTANT, 2001, I, p. 482). 
Guiado por uma concepção do delito político segundo a qual este último só pode ser definido por um julgamento arbitrário que leva em consideração a contingência política - como vimos, "o crime e a inocência são raramente de uma evidência completa" (CONSTANT, 2001, I, p. 481) -, Constant está distante do objetivismo epistêmico que lhe atribui Jaume, para quem o autor franco-suíço tem implícita "a esperança de uma visão, senão objetiva, ao menos podendo estabelecer uma unanimidade sobre o que foi o 'mau uso' do poder' (JAUME, 2000a, p. 239; JAUME, 2001, p. 428). Em nossa perspectiva, é o reconhecimento mesmo da impossibilidade de uma verdade objetiva em política que constitui o ponto de partida da teoria de Constant sobre a responsabilidade dos ministros: como não é possível estabelecer objetivamente se determinada conduta constitui ou não um crime político, essa questão só pode ser objeto de um julgamento arbitrário, inseparável da conjuntura política. O objetivo da responsabilidade dos ministros não é chegar a uma verdade sobre a existência ou não de um crime político, muito menos garantir a punição do ministro culpado, mas manter toda a sociedade em um estado de vigilância, exame e debate sobre as políticas ministeriais. Não cabe ao Rei dizer onde está a verdade, como na interpretação de Jaume, mas apenas temperar os inconvenientes do julgamento inevitavelmente arbitrário da Câmara dos Pares com um possível perdão igualmente arbitrário, o qual faz parte da discricionariedade intrínseca à dignidade monárquica.

Poucos meses após escrever De la responsabilité, Constant teve a oportunidade de incorporar sua teoria da responsabilidade ministerial como julgamento discricionário no Ato Adicional de 22 de abril de 1815. O artigo 41 declara que "todo ministro, todo comandante de exército de terra ou de mar pode ser acusado pela Câmara dos Representantes e julgado pela Câmara dos Pares, por ter comprometido a segurança ou a honra da Nação" (CONSTANT, 2001, II, p. 618). Era afastar o artigo 56 da Carta de 1814, que limitava a responsabilidade aos crimes de traição e concussão. O artigo 41 do Ato Adicional abre espaço para o julgamento político dos ministros, o quais podem ser acusados por uma má administração que comprometeu a segurança ou a honra do país. $\mathrm{O}$ artigo 42 estabelece que "a Câmara dos Pares exerce, neste caso, seja para caracterizar o delito ou para infligir a pena, um poder discricionário" (CONSTANT, 2001, II, p. 618; 
ênfase nossa). Constant consegue, assim, literalmente constitucionalizar a ideia de julgamento arbitrário. ${ }^{125}$

\subsection{Constant perante o confronto entre interpretações parlamentaristas e antiparlamentaristas da Carta de $\mathbf{1 8 1 4}$}

Que impacto essa constitucionalização do julgamento arbitrário dos ministros, teorizada por Constant e inscrita no Ato Adicional de 1815, exerceu sobre o debate político que se seguiu à segunda queda de Napoleão? Contrariamente à interpretação convencional que faz da teoria de Constant inscrita no Ato Adicional uma etapa importante do longo processo de desenvolvimento do parlamentarismo na França, sugerimos aqui que o debate político do início da Segunda Restauração, cedo marcado pelo confronto entre interpretações parlamentaristas e antiparlamentaristas da Carta de 1814, ocorreu à margem do problema político tratado por Constant em sua teoria da responsabilidade dos ministros. Nem as leituras parlamentaristas nem as antiparlamentaristas da Carta seguiram a impulsão de Constant de conceder um lugar constitucional ao julgamento político arbitrário. Pelo contrário, ambas tentaram, cada uma a seu modo, submeter a dinâmica política a princípios fixos, de modo a impedir toda decisão arbitrária. Assim, o contraste com outras interpretações da monarquia constitucional de 1814-1815, formuladas pouco tempo após a de Constant, ajuda a situar a monarquia constitucional constantiana no que acreditamos ser seu devido lugar: não uma etapa na aprendizagem do regime parlamentar pelos franceses, nem uma conciliação entre a soberania guardiã da Verdade e o espírito de livre exame (interpretação de Jaume),

125 Em “Comparaison de l'Ordonnance de réformation de Louis XVIII avec la Constitution proposée à la France le 22 avril 1815”, Constant apresenta os artigos do Ato Adicional sobre a responsabilidade dos ministros como um avanço importante em relação à Carta de 1814: “A responsabilidade dos ministros, limitada, na Carta de 1814, a duas acusações vagas e insuficientes, era ilusória. Era preciso, ou desnaturar o sentido dos termos, ou convir que mil delitos ministeriais estavam isentos de qualquer acusação e julgamento. A Constituição proposta contém uma responsabilidade forte e clara, de modo que um ministro culpado nunca poderá se proteger nos subterfúgios de uma lei escrita, mas encontra sua acusação na energia de uma assembleia animada pelo sentimento popular, e sua sentença na consciência esclarecida de outra assembleia, mais calma, mas não menos independente" (CONSTANT, 2001, II, p.629). 
mas uma tentativa original de constitucionalizar o julgamento arbitrário e de disseminálo no conjunto do edifício institucional - uma tentativa que acabou se tornando isolada no debate político da época do autor, o que demonstra sua especificidade mais do que sua influência imediata.

O evento político que desencadeia o confronto entre interpretações parlamentaristas e antiparlamentaristas da Carta de 1814 referido acima são as eleições de agosto de 1815. Ocorridas em meio ao estado de choque causado pela derrota brutal de Napoleão em Waterloo, pela ocupação estrangeira de três quartos da França pelos exércitos aliados, em julho, e por violências monarquistas no Sul e no Oeste, essas eleições levam à Câmara dos Deputados "uma maioria ultrarrealista pronta a reivindicar 'sangue, correntes, carrascos' contra os culpados pelos Cem Dias” (WARESQUIEL, 1992, p. 409). Luís XVIII, aturdido, como o resto do país, com esse resultado eleitoral improvável, apelida a nova Câmara de "Chambre introuvable". O ímpeto contrarrevolucionário da nova Câmara logo a coloca em rota de colisão com o próprio Rei e seu ministério, os quais optavam então por uma estratégia de reconciliação nacional. O partido ultrarrealista forma então uma verdadeira oposição parlamentar ao ministério nomeado por Luís XVIII, procurando utilizar todos os recursos à sua disposição para barrar ou desfigurar as leis propostas pelo governo, disputar a iniciativa legislativa e a nomeação de cargos, e fazer avançar seu programa de devolução do poder à aristocracia territorial e ao clero.

Paradoxalmente, os porta-vozes dessa oposição parlamentar ultrarrealista, formada por homens comprometidos ideologicamente com o Antigo Regime e o absolutismo monárquico, tornam-se os primeiros formuladores e divulgadores da interpretação parlamentarista da Carta de 1814. O oportunismo das motivações era evidente: em conflito com o Rei e seu ministério, o partido ultrarrealista estava, devido a circunstâncias inusitadas, em condições de reivindicar a legitimidade oriunda das urnas. A conjuntura política da "Chambre introuvable" levava escritores como o Barão de Vitrolles e o Visconde de Chateaubriand a defender a maioria parlamentar saída das urnas como a origem do governo legítimo, no lugar da vontade do Rei. O caráter oportunista e circunstancial dessa interpretação parlamentarista da Carta de 1814 não deve eclipsar sua importância teórica nem sua influência política. Como nota Rials, "os monarquistas mais duros foram os agentes mais eficazes do desenvolvimento de certo estado de espírito favorável ao parlamentarismo sob a Restauração" (RIALS, 1987, p. 93). 
Vitrolles, deputado ultrarrealista que já havia integrado o conselho de Luís XVIII e era próximo do futuro Carlos $\mathrm{X}$, inicia a ofensiva com $\mathrm{Du}$ ministère dans le gouvernement représentatif, de 1815. Essa brochura se propõe a esclarecer as condições do ministério no governo representativo, tendo por fonte de inspiração o funcionamento das instituições políticas inglesas. A primeira condição do ministério é a responsabilidade, sobre a qual o autor desenvolve uma teoria mais ousada do que a de Constant, no sentido de romper mais explicitamente com as disposições da Carta de 1814. Vitrolles critica abertamente o artigo 56 da Carta, que limitava a responsabilidade aos crimes de traição e concussão, argumentando ser inconveniente "determinar de maneira positiva demais todos os casos da responsabilidade" (VITROLLES, 1815, p. 18). Para o autor, os ministros deveriam se retirar assim que fossem condenados pela opinião, sob pena de essa condenação pela opinião se estender ao Rei: “o Rei seria pessoalmente comprometido no instante em que os ministros condenados pela opinião escapassem à execução desse julgamento" (VITROLLES, 1815, p. 20). Vitrolles concebe ainda a possibilidade de uma responsabilidade solidária de todo o ministério, a Câmara dos Deputados podendo solicitar ao Rei o afastamento de todos os ministros por incapacidade ou perda de confiança - possibilidade que Constant havia expressamente excluído. $\mathrm{O}$ autor enfatiza que a Câmara não realiza nesse caso uma acusação ou um julgamento, mas apenas uma reclamação sobre a conduta dos negócios em geral ou sobre o sistema político seguido pelo gabinete. Se o Rei desconfiar que a reclamação da Câmara não está de acordo com a opinião pública, sua única alternativa à demissão imediata dos ministros é dissolver o Parlamento e convocar novas eleições, cabendo ao povo, por meio dos deputados que ele eleger, a decisão final sobre demitir ou não os ministros.

A segunda condição do ministério no governo representativo elencada por Vitrolles é a popularidade, de modo a associar ao governo "o poder da opinião" (VITROLLES, 1815, p. 29). A popularidade pode ser aferida pela maioria da Câmara eletiva, aquela encarregada justamente de expressar a opinião nacional. Segundo o autor, é fundamental que a Câmara participe da nomeação do ministério, mesmo que de modo informal. Embora a Carta atribua apenas ao Rei a nomeação dos ministros, a natureza do governo representativo requer que o monarca escolha "os homens que a opinião da Câmara designaria se ela fosse chamada a participar diretamente dessa nomeação, de maneira que ela possa se ligar a essa designação como sendo, em parte, sua obra" (VITROLLES, 1815, p. 30). Escolhido com base na opinião dominante no Parlamento, o 
ministério deve se manter apenas enquanto contar com o apoio da maioria da Câmara, devendo se retirar assim que perder esse apoio:

Quando os ministros perderam decididamente a maioria na Câmara, eles se
retiram e formam, na maioria dos casos, uma nova oposição. Eles procuram,
assim, extrair uma nova existência na opinião pública, aumentar e tornar mais
coeso seu partido, o qual realiza todos os esforços para os levar novamente à
direção dos negócios públicos (VITROLLES, 1815, p. 42).

Por fim, a terceira condição do ministério no governo representativo elencada por Vitrolles é a unidade. Para o autor, o Rei deve se inspirar no caminho seguido pela Inglaterra desde Robert Walpole e nomear a pessoa mais influente do Parlamento para o cargo de primeiro-ministro, todo o ministério se subordinando a esse cargo e se unificando em torno dessa pessoa. O primeiro-ministro é sustentado, e a unidade do ministério garantida, por um partido específico, o qual, quando é majoritário na Câmara eletiva, tem o direito de imprimir seu espírito particular sobre todo o governo. Vitrolles defende que o Parlamento seja dividido em dois partidos distintos e bem determinados, como os tories e os whigs na Inglaterra, o majoritário formando o governo, e o minoritário, a oposição. O autor chega a fazer um elogio do espírito de partido, em um contexto em que a expressão era predominantemente pejorativa, argumentando que apenas esse espírito partidário habilitaria os franceses a participar da direção política dos negócios do Estado de modo regular, assegurando um governo estável apoiado por um partido majoritário no Parlamento. É surpreendente ver autores contrarrevolucionários como pioneiros na defesa do moderno governo de partidos, mas isso se explica facilmente quando se nota que os ultras eram, nesse início da Segunda Restauração, o grupo político mais coeso e disciplinado no Parlamento, sendo constantemente atacados por seus adversários em função de seu "espírito de partido" (cf. WARESQUIEL, 1992, p. 412413). A interpretação parlamentarista da Carta de 1814 empreendida por Vitrolles não era mais do que uma racionalização da prática política seguida pelos ultras no contexto da "Chambre introuvable".

A ofensiva de Vitrolles é continuada por Chateaubriand em seu De la Monarchie selon la Charte, escrito no período da "Chambre introuvable", mas publicado apenas após sua dissolução por Luís XVIII, em 5 de setembro de 1816. O renomado autor de Génie du christianisme e membro da Câmara dos Pares não é tão sistemático quanto Vitrolles na enumeração das condições do ministério no governo representativo, mas ele estabelece em fórmulas cristalinas a leitura parlamentarista da Carta de 1814 então defendida pelos ultrarrealistas: 
(...) na monarquia constitucional, é a opinião pública a fonte e o princípio do ministério, principium et fons. E, por uma consequência que deriva daquela, o ministério deve sair da maioria da Câmara dos Deputados, porque os deputados são os principais órgãos da opinião popular (CHATEAUBRIAND, 1816, p. 61).

Como Vitrolles, Chateaubriand defende um ministério unificado e governado por um mesmo espírito. Esse espírito deve ser o da maioria da Câmara dos Deputados, intérprete da opinião pública. Uma situação como a da "Chambre introuvable", em que os ministros seguem uma política diferente daquela da maioria parlamentar, é compreendida como uma heresia política (CHATEAUBRIAND, 1816, p. 95). Para o autor, uma divergência política entre o ministério e a maioria da Câmara dos Deputados só pode ter três saídas: ou o ministério consegue mudar o espírito da maioria, ou deve se submeter a ela, ou então se retirar. "Não se governa fora da maioria" (CHATEAUBRIAND, 1816, p. 95). Ao mesmo tempo, Chateaubriand alude ao contexto francês da "Chambre introuvable" de modo mais direto do que o faz Vitrolles, explicitando a política contrarrevolucionária a ser seguida nos marcos mesmos do governo representativo: conservar a obra política da Revolução Francesa consagrada pela Carta de 1814 (o governo da opinião), "mas extirpar a revolução de sua própria obra" (CHATEAUBRIAND, 1816, p. 253), utilizando a maioria parlamentar ultrarrealista para erigir leis que devolvam o poder à aristocracia territorial e ao clero.

A interpretação parlamentarista da Carta de 1814 desenvolvida por Vitrolles e Chateaubriand é criticada por políticos e escritores então chamados de "liberais" (isto é, defensores do legado da Revolução Francesa), especialmente os doutrinários, como fica conhecido o grupo político liderado por Pierre-Paul Royer-Collard e François Guizot, o qual fazia então sua entrada no primeiro plano da cena política francesa. Guizot responde com Du gouvernement représentatif et de l'état actuel de la France, publicado em novembro de 1816. O autor acusa a teoria do governo representativo enunciada por Vitrolles e Chateaubriand de se basear implicitamente no princípio da soberania do povo, reconhecendo o poder eletivo como o único legítimo, do qual todos os outros deveriam derivar. Para Guizot, que passou a vida inteira criticando o princípio da soberania do povo, o que caracteriza o governo representativo é a introdução de um poder eletivo, mas é um erro ver nele um poder autônomo do qual deveriam derivar os outros poderes. Seu ponto de partida é a necessidade de unidade no governo, ou seja, de que o poder encarregado de regrar e dirigir os interesses gerais da sociedade possa realizar sua tarefa sem ser entravado em sua ação por obstáculos que comprometam sua existência 
(GUIZOT, 1816, p. 26). Guizot se faz, assim, um herdeiro do "liberalismo da ordem" tratado no Capítulo 1 desta tese (especialmente da noção de uma harmonia entre os poderes sugerida por Necker), bebendo também do sistema de unidade de Sieyès e de sua crítica ao equilíbrio de poderes. O doutrinário chega à conclusão de que as Câmaras não devem ser vistas como um poder derivado do povo e independente do Rei, mas como uma oposição interna ao próprio governo, a qual o esclarece e indica o limite que ele não pode ultrapassar. Essa seria a verdadeira teoria do governo representativo na Inglaterra, país em que se completou o processo histórico de fusão dos poderes, o Rei, a Câmara dos Lordes e a Câmara dos Comuns formando um único poder, o Rei no Parlamento.

Essa teoria da unidade governamental leva Guizot a refutar a distinção entre poder régio e poder ministerial, cara tanto a Constant como a Vitrolles e Chateaubriand. O doutrinário critica os que relegam o Rei a uma autoridade simbólica e a intervenções pontuais no jogo político, argumentando que o monarca deve governar efetivamente e exercer a realidade do poder. O ministério não pode ser visto como um quarto poder, mas deve ser entendido como um prolongamento do poder do Rei, o titular do Poder Executivo e de uma parte do Legislativo. A combinação entre inviolabilidade régia e responsabilidade ministerial não serviria para separar o poder do Rei do de seus ministros. Pelo contrário, a inviolabilidade serviria para conferir mais força à ação do Rei. A responsabilidade dos ministros, por sua vez, não seria mais do que "uma condição imposta aos agentes do poder, a qual os coloca na necessidade de usar todos os seus meios para conter o próprio poder que os emprega nos limites legais determinados pelas instituições" (GUIZOT, 1816, p. 38). Longe de constituir um modo de a sociedade controlar o governo, a responsabilidade dos ministros seria um dos mecanismos pelos quais o governo se automodera e se esclarece, os ministros podendo utilizar a justificativa de sua responsabilidade para se contrapor aos projetos demasiadamente ambiciosos do Rei e convencê-lo a mudar de ideia, sob pena de sua demissão. De todo modo, "é o Rei que quer e que age, que tem sozinho o direito de querer e o poder de agir. Os ministros são encarregados de esclarecer sua vontade" (GUIZOT, 1816, p. 39).

Guizot refuta igualmente a ideia de que a maioria parlamentar teria um direito intrínseco ao governo. Para o autor, "a maioria é uma quantidade incerta e variável; ganha-se-a, perde-se-a, recupera-se-a" (GUIZOT, 1816, p. 41-42). Ela não é uma pessoa real com direitos, vontades e poderes, mas apenas uma força vacilante disputada pelos partidos. O governo pertence de direito ao "Poder Executivo que participa do Poder 
Legislativo" (GUIZOT, 1816, p. 46), "o único poder materialmente ativo na sociedade" (GUIZOT, 1816, p. 46), no qual "reside necessariamente o princípio do movimento político" (GUIZOT, 1816, p. 46). No governo representativo, esse Poder Executivo concentrado no Rei deve tentar conquistar a maioria parlamentar, pois essa condição é uma garantia dos direitos da nação e um mecanismo de autocontenção do governo. Porém, isso não equivale ao direito de a maioria parlamentar invadir o governo, como os ultrarrealistas haviam tentado fazer durante a "Chambre introuvable". Pelo contrário, tanto a Carta de 1814 como a constituição inglesa asseguram ao Rei meios de conquistar a maioria parlamentar por sua própria iniciativa, como a influência sobre as eleições e o direito de dissolução, evitando-se assim que o monarca se torne presa de facções parlamentares como a dos ultras.

A crítica de Abel François Villemain, outro expoente do círculo doutrinário, à interpretação parlamentarista da Carta de 1814 complementa a de Guizot. Em Le Roi, la Charte et la Monarchie, de 1816, ele argumenta que a Carta não pode ser dissociada do contexto histórico que a originou, ou seja, do pacto pelo qual o Rei teria prometido defender as conquistas da Revolução Francesa e o estado social igualitário. Em outras palavras, seria falacioso tratar a Carta e o governo representativo como disposições abstratas que poderiam servir a qualquer fim, inclusive ao restabelecimento da dominação do clero e da nobreza. Para Villemain, como para os doutrinários em geral, o governo representativo tem um conteúdo histórico e de classe específico: ele só pode servir para consagrar a vitória histórica e legítima da classe média, burguesia ou Terceiro Estado, da qual Guizot se tornará o grande teórico. "Esse governo representativo, que é visto como o mais feliz produto da civilização, não é outra coisa do que a participação do Terceiro Estado no exercício do poder" (VILLEMAIN, 1816, p. 15). Procurar fazer o governo representativo servir aos interesses de outra classe ou a outro objetivo político seria desnaturá-lo de partida.

Villemain faz ainda uma distinção entre as histórias da França e da Inglaterra, a fim de criticar a imitação servil do modelo parlamentar britânico. A constituição inglesa existia antes dos Stuart, tendo precisado se defender dessa dinastia. A Carta de 1814, por sua vez, seria uma obra dos Bourbon. A defesa da Carta passaria, portanto, pelo fortalecimento do poder do Rei, o maior interessado na conservação de sua obra, na contramão do que propunham as interpretações parlamentaristas de Vitrolles e Chateaubriand. Para Villemain, refletindo a opinião doutrinária, o que importa não é as 
disposições formais da Carta ou a teoria abstrata do governo representativo, mas o conteúdo histórico que a Carta deve realizar e o papel pessoal de Luís XVIII como fiador do pacto que uniu o Terceiro Estado à dinastia Bourbon. É principalmente como fiador desse pacto que o Rei deve dispor de um poder ativo e considerável na condução do governo.

E quanto à responsabilidade dos ministros? Como Guizot, Villemain refuta que a combinação entre inviolabilidade régia e responsabilidade ministerial sirva para separar o poder do Rei do de seus ministros, entregando a direção efetiva do governo a estes últimos:

(...) em qualquer monarquia, a vontade pessoal do monarca tem sempre uma força prodigiosa. A responsabilidade dos ministros não consiste na supressão dessa vontade, mas na impossibilidade de invocá-la para justificar atos ilegais ou abusos de poder, o que seria um absurdo e uma blasfêmia (VILLEMAIN, 1816, p. 31).

Em outras palavras, a responsabilidade dos ministros é apenas uma prevenção contra medidas governamentais ilegais, para a defesa das quais os ministros são proibidos de invocar a vontade do Rei. Tornar os ministros responsáveis equivale a supor um juramento tácito da parte de qualquer indivíduo que aceita um ministério: "eu presumo suficientemente a sabedoria do Rei, para acreditar que ele nunca me prescreverá, sem ter antes me escutado, ordens que comprometem uma responsabilidade que eu, de resto, aceito inteiramente e sem reservas" (VILLEMAIN, 1816, p. 34-35). Como Guizot, Villemain vê, na responsabilidade dos ministros, um incentivo para que os ministros esclareçam efetivamente a vontade do Rei, uma vez que eles sofrerão as consequências de qualquer medida ilegal ou abuso de poder.

Assim, o confronto entre interpretações parlamentaristas e antiparlamentaristas da Carta de 1814 produzido pela experiência da "Chambre introuvable" engendrou duas compreensões antagônicas da responsabilidade dos ministros. Na interpretação parlamentarista, a responsabilidade é estritamente política e desprovida de formas judiciais. Seu objetivo é colocar o ministério sob o controle imediato da maioria da Câmara dos Deputados, fazendo o ministério mudar a cada oscilação da opinião pública aferida em eleições. A interpretação antiparlamentarista, ao contrário, enfatiza o poder pessoal do Rei e vê o ministério como uma extensão desse poder, de modo mais compatível com as intenções originais dos redatores da Carta de 1814 (apesar da mudança de justificativa teórica, os doutrinários caracterizando Luís XVIII como um aliado do 
Terceiro Estado, o que certamente não estava no horizonte na época da redação da Carta). Desse modo, a interpretação antiparlamentarista tende a compreender a responsabilidade dos ministros na chave estritamente judicial, em conformidade com as disposições explícitas da Carta de 1814. A responsabilidade ministerial não aparece como um controle da sociedade ou do Parlamento sobre o ministério, nem como um modo de transformar os ministros em um poder autônomo, mas como uma simples maneira de evitar os atos ilegais e os abusos de poder por via judicial, obrigando o governo a se automoderar e incentivando os ministros a esclarecer a vontade do Rei.

Oriundas de uma conjuntura política bastante específica - a da "Chambre introuvable" -, essas posições não serão defendidas de modo fixo pelos mesmos autores e atores políticos. Após perderem a maioria da Câmara dos Deputados, muitos ultrarrealistas voltarão a insistir na soberania exclusiva do Rei. Os doutrinários, por sua vez, abraçarão leituras mais parlamentaristas da Carta de 1814 na década de 1820, quando se encontrarão na oposição. ${ }^{126}$ Apesar dessa oscilação dos autores e atores políticos, as duas leituras da Carta expostas acima permanecem influentes ao longo da Segunda Restauração, informando o debate acerca dos diversos projetos de lei sobre a responsabilidade dos ministros. Assim, por exemplo, em sua brochura De la responsabilité des ministres, de 1817, Marchais de Migneaux critica a tentativa de implantar na França um regime parlamentar à inglesa, insistindo nos principais pontos da interpretação antiparlamentarista da Carta de 1814 formulada pelos doutrinários em 1816: o Rei é o titular exclusivo do Poder Executivo, e o governo se concentra em sua pessoa; os ministros são uma extensão do poder do monarca, não havendo corpo ministerial unificado, nem distinção entre poder régio e poder ministerial; a responsabilidade dos ministros é um mecanismo puramente judicial que só se aplica aos crimes de traição e concussão, não servindo para afastar ministros acusados de seguir uma política perniciosa; apenas o Rei tem o direito de demitir um ministro por julgar sua política inoportuna. Migneaux chega a sugerir que a possibilidade de responsabilizar os ministros por todos os atos de governo - possibilidade entrevista por ele no projeto de lei de Gérard de Lally-Tollendal - “deve abrir as portas para todas as interpretações arbitrárias”

${ }^{126}$ Rials (1987, p. 91-92) analisa as mudanças de posição a esse respeito nos discursos de RoyerCollard, líder dos doutrinários na Câmara dos Deputados. Guizot defenderá uma influência decisiva das Câmaras na formação do ministério, no Capítulo 10 de Du gouvernement de la France depuis la Restauration et du ministère actuel, de 1820 (GUIZOT, 1820, p. 283-284). 
(MIGNEAUX, 1817, p. 83). A interpretação parlamentarista, por sua vez, também permanece repercutindo ao longo da Segunda Restauração, tendo muitas vezes por portavozes aqueles que a criticaram em $1816 .^{127}$

Como Constant se situa nesse embate entre interpretações parlamentaristas e antiparlamentaristas da Carta de 1814, característico da Segunda Restauração? Assim que Vitrolles e Chateaubriand desenvolvem a interpretação parlamentarista, alguns veem nela uma apropriação contrarrevolucionária das ideias de Constant. Villemain, por exemplo, ironiza: "O Sr. Chateaubriand consagra seu talento a reproduzir e, se se quiser, a reabilitar as teorias tão bem expostas por Benjamin Constant" (VILLEMAIN, 1816, p. 7). O próprio Constant percebeu, em De la Monarchie selon la Charte, um eco de sua teoria da monarquia constitucional. Em De la doctrine politique qui peut réunir les partis en France, de 1817, o autor franco-suíço ataca o livro de Chateaubriand de 1816, sugerindo que ele deveria se chamar Da Carta segundo a Aristocracia (CONSTANT, 2010, I, p. 317), e vendo nele uma estratégia odiosa de se servir do governo representativo para operar a contrarrevolução. Todavia, ao reimprimir as Réflexions sur les constitutions no Cours de politique constitutionnelle de 1818, Constant acrescenta notas elogiosas a De la Monarchie selon la Charte, alegando que quisera combater apenas as consequências contrarrevolucionárias extraídas por Chateaubriand, considerando os princípios constitucionais expostos no início do livro perfeitamente justos (CONSTANT, 1982, p. 303). Na nota C ("Du pouvoir royal"), o autor afirma que Chateaubriand reproduziu suas ideias sobre a monarquia constitucional, mas as exagerou um pouco. $\mathrm{O}$ exagero poderia ser enxergado no Capítulo 5 de De la Monarchie selon la Charte, no qual se lê que o Rei nunca deve insistir sobre a ação de um ministro, mas deixá-lo agir mesmo que em desacordo com a opinião do monarca: não caberia ao Rei impedir o ministro de errar, mas deixá-lo errar e perder seu cargo, para depois mudar de ministério (CHATEAUBRIAND, 1816, p. 10). Constant considera um exagero reduzir tanto assim o monarca ao papel de espectador:

Certamente, não é assim que eu entendo a questão. Quando o rei vê um ministro prestes a cometer um erro, ele não permanece impassível. Ele não o deixa cometer um erro cujas consequências nefastas recairiam sobre a nação.

127 São essas mudanças de posição que nos fazem preferir as expressões "interpretações parlamentaristas e antiparlamentaristas da Carta de 1814”, em vez de se referir, por exemplo, a uma interpretação ultra e uma interpretação doutrinária. Contrastar com a classificação de interpretações da Carta estabelecida em JAUME, s.d. 
Ele não força seu ministro, mas o demite antes que o erro seja cometido (CONSTANT, 1982, p. 299).

Esse breve comentário constitui um bom indício do que afasta Constant da interpretação parlamentarista da Carta de 1814 difundida por Chateaubriand. Aos olhos de Constant, o Rei de Chateaubriand não é um poder neutro, mas um simples espectador de um jogo político no qual só contam verdadeiramente o ministério e a Câmara dos Deputados. Constant não queria relegar o monarca a uma postura passiva, mas fazer dele o órgão por excelência da decisão política, distinta ao mesmo tempo do governo, da legislação e da atividade judiciária. O Rei não poderia fazer mais do que nomear e demitir ministros, indicar para a Câmara dos Pares, dissolver a Câmara dos Deputados, sancionar as leis, nomear juízes inamovíveis e conceder graça, mas, nessas atribuições pontuais, ele seria um verdadeiro guardião da Constituição, sempre vigilante para frear os desvios dos poderes Executivo, Legislativo e Judiciário. Chateaubriand, por sua vez, subordinaria tudo à autoridade exclusiva da assembleia eleita. Desde o Diretório e a experiência que levou ao golpe do 18 Frutidor, Constant é sensível ao perigo de uma assembleia eleita tomada por furores contrarrevolucionários - uma experiência que se repete com a “Chambre introuvable". Desde aquela época, sua preocupação é com a decisão discricionária autorizada constitucionalmente a dissipar o perigo trazido pelas urnas. ${ }^{128}$ Essa decisão vinda de uma instância não eletiva é o que falta nas interpretações parlamentaristas da Carta de 1814, distinguindo-as da monarquia constitucional constantiana.

Constant e as interpretações parlamentaristas da Carta se diferenciam fundamentalmente no papel atribuído à opinião pública. Como vimos, para Vitrolles e Chateaubriand, é a opinião, tal como expressa na eleição para a Câmara dos Deputados, que deve elevar e destituir os ministros. Constant também desejava associar a opinião ao mecanismo da responsabilidade dos ministros, mas tomando muito mais precauções

128 Suanzes está correto em sua interpretação segundo a qual Constant via no Rei um "poder de reserva" capaz de frear a vontade parlamentar oriunda das urnas, mas ele é totalmente anacrônico ao relacionar essa atitude de Constant ao objetivo de "impedir uma brusca e radical democratização do Estado constitucional, tal como havia ocorrido em 1793” (SUANZES, 1991, p. 138). Se o autor franco-suíço considerava importante impor um freio à vontade parlamentar oriunda das urnas, o que o motivava era o medo da contrarrevolução, dado o bom desempenho eleitoral do partido ultrarrealista e contrarrevolucionário, não o medo de uma "democratização jacobina” ocorrida mais de vinte anos antes, em um contexto histórico totalmente diferente. 
contra o império absoluto da opinião: "um governo representativo deve, sem dúvida, ser submisso à opinião; mas ele deve conter os meios de a reprimir momentaneamente; e, sobretudo, os de reprimir os homens que, desfigurando-a, apresentam-se como seus órgãos" (CONSTANT, 2010, I, p. 175). O autor afirma isso em sua defesa da hereditariedade do pariato, na resenha de Des désordres actuels de la France et des moyens d'y remédier, de Montlosier, publicada em outubro de 1815, em Le Courrier. Com efeito, a Câmara dos Pares hereditária é, para Constant, um contrapeso indispensável, ao mesmo tempo às autoridades régia e ministerial e à opinião representada na Câmara dos Deputados, a qual pode ser ou não a mesma do povo. Por isso, sua ênfase na necessidade de que o julgamento dos ministros seja realizado pelos pares. ${ }^{129}$ Para ele, a simples impopularidade de um ministro na Câmara dos Deputados não é uma condição suficiente para sua saída - daí sua oposição à possibilidade de a Câmara declarar os ministros indignos da confiança pública, defendida por Vitrolles e implícita em De la Monarchie selon la Charte. Não se deve supor a razoabilidade da maioria parlamentar e sua coincidência absoluta com a vontade do povo como um princípio fixo e necessário. Se a correlação de forças políticas da Câmara dos Deputados deve ser o elemento preponderante para a acusação de um ministro, apenas o julgamento imparcial e discricionário dos pares pode dar conta da complexidade da situação política em questão, evitando que uma facção parlamentar como a dos ultras se aproprie da opinião pública como um passaporte para o poder absoluto.

O fundamental é a divergência de Constant com a ideia de que a opinião pública deve elevar e destituir os ministros, entendida como um princípio fixo a regular a política representativa. Para o autor, tal princípio fixo não pode existir fazendo-se abstração da contingência política. Dependendo do contexto, a opinião pode estar equivocada, falseada ou manipulada por uma facção que fala em nome do povo. Se é importante associar a opinião ao mecanismo de responsabilidade dos ministros, isso deve ocorrer por meio da multiplicação de instâncias encarregadas de julgar a contingência política, não erigindo

${ }^{129}$ No fim da vida, Constant passa a apresentar mais reservas sobre a possibilidade de criar uma Câmara dos Pares hereditária em uma nação democrática moderna (cf. CONSTANT, 1982, p. 315). Por isso, em seu artigo "Responsabilité ministérielle", publicado em Le Temps em 31 de maio de 1830, a assembleia encarregada de julgar os ministros não precisa ser necessariamente hereditária, podendo ser apenas vitalícia ou nomeada para um período mais longo do que o da assembleia encarregada de representar a opinião (CONSTANT, 1989, p. 160). 
as oscilações da opinião pública aferidas em eleições como $o$ princípio da responsabilidade dos ministros. É o reconhecimento dessa impossibilidade de submeter a responsabilidade dos ministros a um princípio fixo que leva Constant a insistir no caráter inevitavelmente arbitrário desse procedimento (ver a Seção 4.2). Se ocorre um conflito entre Câmaras e ministério, a necessidade de o ministério se curvar à maioria parlamentar não pode ser transformada em um princípio necessário, como na interpretação parlamentarista. A necessidade de um julgamento que dê conta da contingência política é indispensável. Embora o lócus por excelência desse julgamento seja a Câmara dos Pares, instituição à qual Constant atribui algumas das características do poder neutro, seu objetivo é que esse julgamento envolva o conjunto do edifício constitucional, da Câmara dos Deputados ao Rei, mobilizando cada um dos cidadãos por meio da dinâmica da opinião.

Percebe-se, assim, o problema de se tratar a teoria da responsabilidade dos ministros de Constant como uma etapa no longo caminho de aclimatação do regime parlamentar na França. Não se pode afirmar que Constant misturou a responsabilidade política a formas judiciais apenas porque ele ainda não compreendia bem o regime parlamentar em sua pureza, ou porque ele achava que a França ainda não estava totalmente preparada para vivenciar o parlamentarismo do modo como ele era praticado na Inglaterra, como sugere Laquièze (2000, p. 175). No início da Segunda Restauração, $\mathrm{o}$ autor teve acesso às teorias autenticamente parlamentaristas de Vitrolles e Chateaubriand (embora esses autores ainda não tivessem um domínio técnico do funcionamento do parlamentarismo, eles estabeleceram seu princípio político), e, em vez de endossá-las, Constant marcou sua diferença com elas, insistindo no julgamento arbitrário realizado pela Câmara dos Pares como o cerne do mecanismo de responsabilidade dos ministros. Com efeito, no fim de sua vida, o artigo "Responsabilité ministérielle", publicado em Le Temps em 31 de maio de 1830, continua insistindo no mesmo ponto de seu texto de 1815 sobre a responsabilidade dos ministros - o caráter inevitavelmente arbitrário do julgamento a ser realizado, não sendo possível submetê-lo a um princípio fixo:

Deixem, portanto, à lei de responsabilidade o arbítrio que lhe é inseparável. Mas estabeleçam, ao mesmo tempo, regras diferentes das que são admissíveis quando a letra da lei previu tudo. Um tribunal investido de um poder discricionário deve dar aos acusados, por sua organização, a garantia de que ele não abusará desse poder. Quanto maior é a latitude, mais a posição dos juízes deve ser imparcial, e mais as penas devem ser moderadas (CONSTANT, 1989, p. 159-160). 
No entanto, a divergência entre Constant e as interpretações parlamentaristas da Carta de 1814 não o aproxima tampouco das interpretações antiparlamentaristas. Como vimos, as críticas das interpretações parlamentaristas da Carta tenderam a refutar a separação entre os poderes régio e ministerial, cara a Constant, considerando o ministério como uma extensão do poder do monarca e limitando a responsabilidade a sua acepção puramente penal, restrita aos crimes de traição e concussão. Nas interpretações antiparlamentaristas, o Rei deixa de ser um poder neutro e se torna um governante efetivo, o chefe do Poder Executivo. Se o arbítrio aparece na forma de uma vontade potencialmente ilimitada do monarca, a qual é encarregada de se autolimitar com base na oposição “interna” fornecida pelas Câmaras e por ministros responsáveis, ele está ausente no lugar em que Constant gostaria que ele estivesse, ou seja, no julgamento dos ministros. Ao se tornar puramente judicial e regulada por leis precisas, a responsabilidade dos ministros é submetida a princípios fixos, tal como na interpretação parlamentarista, mas em uma chave oposta. A interpretação parlamentarista submete a responsabilidade dos ministros a um princípio fixo ao torná-la puramente política, de modo que uma oscilação da opinião pública aferida em eleições para a Câmara dos Deputados deveria resultar necessariamente em uma mudança no ministério. A interpretação antiparlamentarista, por sua vez, submete a responsabilidade dos ministros a um princípio fixo ao torná-la puramente judicial, como se se tratasse do julgamento de um crime comum.

A particularidade da teoria de Constant sobre a responsabilidade dos ministros consiste em, diferentemente dessas duas correntes interpretativas da Carta de 1814, unir a forma julgamento a um processo reconhecidamente político, como uma forma de abarcar o caráter inexpugnavelmente contingente da política, a qual não pode ser submetida a princípios fixos. O julgamento é necessário porque mesmo o império da opinião não pode ser transformado em um princípio fixo e automático, um poder imparcial devendo julgar se aquilo que se apresenta como a opinião tem realmente o direito de falar em nome do povo e exigir uma mudança de política ministerial. Mas esse julgamento deve ser arbitrário, já que uma avaliação das políticas seguidas por um ministro não pode ocorrer segundo um código fixo de princípios e regras, devendo levar em consideração o imponderável da contingência política. Alheio às interpretações parlamentaristas e antiparlamentaristas da Carta de 1814 que polarizaram o debate político da Segunda Restauração, com sua tendência a submeter a dinâmica política a princípios fixos, Constant se concentrou em afinar teoricamente o paradigma por 
excelência da decisão arbitrária necessária na política representativa: o julgamento político. 


\section{Conclusão}

Vimos, no Capítulo 1, o problema do arbítrio emergir no pensamento do jovem Constant, no contexto do Primeiro Diretório (1795-1797), atrelado à questão da legitimidade das possíveis medidas arbitrárias a serem adotadas para salvar a República de uma opinião pública não republicana, no quadro de um diagnóstico segundo o qual a Revolução Francesa ainda não estava terminada e enfrentava um perigoso espírito de reação. Em um primeiro momento, esse problema é respondido pela rejeição incondicional do arbítrio, o autor buscando equilibrar essa rejeição com o princípio da soberania do povo e a independência do governo republicano em relação à maioria nacional. No Capítulo 2, vimos o golpe do 18 Frutidor revelar a precariedade desse equilíbrio, o qual se rompe no discurso que Constant faz em defesa do golpe, cujo caráter flagrantemente contraditório exige uma reformulação do pensamento do autor. Essa reformulação ocorre nos Fragments d'un ouvrage abandonné sur la possibilité d'une constitution républicaine dans un grand pays, em que o arbítrio é incorporado na autoridade discricionária do poder neutro, cuja posição estrutural e cujas prerrogativas são pensadas como garantias da não degeneração do arbítrio em tirania - garantias que estariam ausentes nas respostas ao 18 Frutidor formuladas em seu entorno, nas penas de Roederer, Bonaparte, Staël, Sieyès, Cabanis e Necker. Assim, a primeira resposta refletida de Constant ao problema do arbítrio consiste em lhe conferir um espaço regular (não excepcional) no sistema político institucional, tomando o cuidado de isolar essa decisão discricionária de todas as outras funções políticas (governo, legislação e aplicação judicial das leis). O arbítrio é neutralizado por meio de sua concentração em um poder constitucional específico que não tem outras atribuições - por isso mesmo chamado de neutro.

Não obstante, o fim da República e o direcionamento do pensamento de Constant para uma filosofia liberal que prioriza os princípios da liberdade individual em relação às formas de governo confere ao problema do arbítrio uma nova complexidade, de modo que o isolamento e a concentração do arbítrio em um poder constitucional específico se tornam insuficientes. No Capítulo 3, vimos que as considerações do autor sobre a insuficiência da lei para a garantia da liberdade, ou mesmo a possível ilegitimidade moral da lei, levam-no a introduzir novas instâncias de decisão discricionária para além do poder 
neutro. No limite, essa decisão discricionária é colocada ao alcance de cada membro da comunidade política, como vimos na discussão de Constant sobre aquilo que se chamará mais tarde de desobediência civil. Portanto, o autor passa da concentração à disseminação do arbítrio no interior do edifício constitucional. Antes restrito ao domínio da decisão emergencial que visa a salvar a República de um perigo urgente, o arbítrio entra no âmbito do julgamento moral realizado por cada consciência individual acerca da justiça da lei e de sua boa adequação ao caso particular em questão - um julgamento que é arbitrário no sentido de não se reduzir à aplicação de princípios fixos e racionais, tirando seu fundamento da incomensurabilidade do sentimento religioso como fonte da moral.

A conversão de Constant à monarquia constitucional, a partir de 1814, analisada no Capítulo 4, conecta a disseminação do arbítrio deduzida dos Principes de politique de 1806, no âmbito da discussão sobre os princípios da liberdade individual, com a construção constitucional esboçada nos Fragments, agora transposta para um contexto monárquico. O Rei constitucional passa a encarnar o poder neutro cuja necessidade constituía a conclusão dos Fragments. Com isso, à discricionariedade do poder neutro soma-se a dose de arbítrio intrínseca à supremacia simbólica do monarca, cuja conceituação a partir da separação de fato em relação às atividades propriamente governativas do Poder Executivo une as teorias antagônicas de Constant e Maistre. No entanto, o arbítrio não é mais concentrado no poder neutro tornado monárquico. A interpretação constantiana do mecanismo de responsabilidade dos ministros fornece uma maneira de difundir a decisão discricionária entre diversas instâncias constitucionais e enraizar esse processo no próprio cidadão, cuja participação por meio do exame crítico dos atos do governo, das petições individuais e do acompanhamento dos debates constitui a finalidade mesma da responsabilidade dos ministros, justificando o traço fundamental da publicidade. A responsabilidade dos ministros se torna um paradigma da decisão arbitrária requerida pela insuficiência da lei perante o imponderável da contingência política - uma insuficiência política da lei que completa a insuficiência moral analisada no Capítulo 3, tendo como referência os Principes de politique de 1806. Assim, a teoria constantiana da monarquia constitucional faz o arbítrio passar do julgamento moral da consciência individual ao julgamento político que envolve todas as partes relevantes do edifício constitucional (a Câmara dos Deputados, a Câmara dos Pares, o Rei, os cidadãos que acompanham os debates e peticionam). Esse julgamento político se caracteriza pela recusa de submeter a política a princípios fixos, na contramão das interpretações tanto 
parlamentaristas como antiparlamentaristas da Carta de 1814 que se digladiam no início da Segunda Restauração.

Esse percurso nos permite reavaliar algumas representações da obra de Constant referidas na Introdução. Por exemplo, no artigo "État d'exception et coup d'État dans la pensée du Groupe de Coppet”, de 2003, mencionado na Introdução e no Capítulo 2 desta tese, Alain Laquièze sublinha a originalidade do grupo de Coppet na condenação incondicional de qualquer medida arbitrária, rompendo com toda a tradição da filosofia política que havia pensado os casos excepcionais em que a lei pode ser contornada com vistas à salvação pública - uma interpretação do pensamento de Constant e Staël que poderia fazê-los figurar na posição de fundadores da concepção forte de império da lei subjacente ao Estado liberal moderno. Na representação correspondente, mas oposta do ponto de vista valorativo, sugerida por Schmitt em $O$ conceito do político, a sociedade comercial moderna louvada por Constant representa a morte da esfera do político, na medida em que o império da lei e a racionalização da sociedade promovem a dissolução da dimensão da soberania e da decisão.

Ora, esta tese procurou demonstrar que, por mais que Constant tenha tentado no início, ele não conseguiu suprimir totalmente a esfera do arbítrio e da decisão, e por isso seu problema passa a ser como incorporar essa esfera à vida política impedindo sua degeneração em tirania. Portanto, sua ruptura com a tradição anterior que pensou os casos excepcionais em que a lei pode ser contornada com vistas à salvação pública é relativa. Do mesmo modo, a representação de Constant como um "pai" da concepção forte de império da lei subjacente ao Estado de Direito moderno contribui para obscurecer alguns pontos de tensão em seu pensamento que, se trazidos à luz do dia, revelam aspectos de sua obra de grande relevância para a teoria política.

Sobre a relação de Constant com a tradição da filosofia política em voga até a Revolução Francesa, o que se pode dizer é que ele se inscreve em uma problemática já tratada por autores como Maquiavel, Locke e Rousseau (como incorporar o inevitável arbítrio à vida política e evitar ao mesmo tempo sua deriva tirânica), mas construindo um paradigma de incorporação controlada do arbítrio que diverge dos erigidos por esses autores clássicos. Em primeiro lugar, a ditadura, louvada por Maquiavel e Rousseau, segundo a leitura que eles fazem da história da República romana, é inteiramente rechaçada por Constant. Para o autor franco-suíço, não poderia haver suspensão legítima da ordem constitucional regular, nem há perigos que justifiquem essa suspensão. Em 
primeiro lugar, porque o retorno à ordem constitucional depois de sua interrupção é sempre difícil. Em segundo lugar, porque o poder absoluto e ilimitado de um ditador é sempre um perigo, mesmo nos casos em que a Constituição determina um prazo para o exercício desse poder absoluto e proíbe o ditador de instituir leis para os períodos regulares (“ditadura comissarial”). Em relação ao poder absoluto e ilimitado, Constant é categórico e intransigente: ele nunca pode ser legítimo, nem mesmo por um breve período de tempo. Desse modo, a noção de estado de exceção, cuja influência nos anos da Revolução Francesa foi mencionada no Capítulo 1, é abandonada por Constant para pensar o problema do arbítrio. Ao contrário de Maquiavel, Rousseau e muitos revolucionários franceses, o autor franco-suíço não pensa o arbítrio na chave de momentos excepcionais em que, a República estando em perigo, as leis ordinárias são suspensas e poderes ilimitados entram em cena até que esse perigo seja repelido. Para ele, a autoridade discricionária deve fazer parte do edifício constitucional regular.

Outro paradigma da incorporação controlada do arbítrio com o qual Constant rompe é a prerrogativa régia teorizada por Locke. $\mathrm{O}$ autor franco-suíço é sensível às considerações de seu predecessor inglês sobre a impossibilidade de a lei prever tudo e sobre a necessidade de uma vontade que possa decidir às margens da lei, por vezes contra a letra da lei, nos casos em que a aplicação literal da lei causaria mais mal do que bem à comunidade política. Contudo, Constant diverge do procedimento lockeano de atribuir a faculdade de decidir discricionariamente à margem das ou contra as leis existentes a um Rei considerado como chefe do Poder Executivo, e autorizado a estender sua prerrogativa a todos os âmbitos da vida social nos quais ele poderia opor o bem comum à letra da lei, tendo como único freio a revolta popular. Em primeiro lugar, mesmo quando atribui a autoridade discricionária do poder neutro ao Rei, o autor franco-suíço tem o cuidado de desvincular essa autoridade do Poder Executivo, mantendo a decisão discricionária e o governo em polos separados. Consequentemente, o poder neutro constantiano não pode agir sobre todas as instâncias da vida coletiva em que o bem comum poderia ser oposto à letra da lei, como o pode o Rei lockeano dotado da prerrogativa. O exemplo, fornecido por Locke, da demolição da casa de um homem inocente para deter um incêndio quando a casa vizinha está em chamas (LOCKE, 2005, p. 529, §159) seria totalmente deslocado na obra de Constant, para quem o poder neutro não é autorizado a agir contrariamente às leis em quaisquer circunstâncias, mas possui atribuições constitucionais bastante específicas. Se, por um lado, o autor franco-suíço é sensível aos argumentos sobre a 
insuficiência da lei e sua incapacidade de prever tudo, por outro lado, ele tem mais reservas do que Locke em relação à máxima Salus populi suprema lex, pois a experiência do Terror lhe ensinou que palavras como justiça, virtude, bem comum e salvação pública podem ser manipuladas por tiranos demagógicos: “(...) a justiça, a virtude, podem ser desfiguradas. Seus nomes estão à mercê de quem quiser empregá-los. Robespierre pode invocar a pátria, a liberdade, a moral, como Lanjuinais" (CONSTANT, 1998a, p. 377; cf. p. 84 supra). Assim, Constant mantém ao longo de toda a sua obra uma primazia das formas em relação ao fundo do bem comum. Mesmo quando ele cede um espaço controlado ao arbítrio, esse arbítrio é regulado por leis que especificam quais ações as autoridades imbuídas de um poder discricionário podem realizar (dissolver assembleias representativas, perdoar crimes, julgar ministros sem que o crime em questão seja definido por uma lei prévia, etc.). Essa primazia das formas leva Constant a rejeitar a proposição de Locke segundo a qual a prerrogativa dos reis sábios e bons pode ser estendida sem prejuízo à comunidade política, uma vez que esses príncipes agem, mesmo sem a letra da lei ou contrariamente a ela, "conforme ao fundamento e ao fim de todas as leis, o bem público" (LOCKE, 2005, p. 533, §165). Para Constant, ao contrário, “é precisamente sob príncipes esclarecidos e sábios, que a liberdade deve ser cercada de todos os seus meios de defesa" (CONSTANT, 2001, I, p. 487). Afinal, para o autor franco-suíço, não é a virtude do príncipe ou de qualquer outro agente político que justifica a maior ou menor discricionariedade. Em sua obra, a incorporação controlada do arbítrio está ligada a posições estruturais e atribuições específicas reguladas pela Constituição, jamais a uma pressuposição sobre a bondade ou maldade de determinadas pessoas. Em sua visão, um monarca como o de Locke, que estendesse sua ação discricionária aos mais diversos âmbitos nos quais achasse que sua ação contrária às leis contribuiria para o bem comum, seria um tirano, mesmo que sua ação em prol do bem público fosse sincera. Por fim, a revolta popular, pensada por Locke como o meio por excelência de impedir a degeneração da prerrogativa em tirania, não é menos problemática para Constant. Se a desobediência às leis consideradas injustas é, para ele, um direito inalienável do indivíduo, a revolução não pode ser pensada como garantia contra a tirania. A chave de compreensão do fenômeno revolucionário não é constitucional, mas histórica: uma revolução se explica e se justifica quando o progresso das instituições políticas não acompanhou o progresso das ideias e do estado social, uma convulsão violenta sendo necessária para restabelecer o acordo entre ideias e instituições. Pensar a possibilidade da revolução como a garantia última contra a tirania, como o faz Locke, implica, na 
perspectiva de Constant, preocupada em terminar a Revolução Francesa, não sair da oscilação entre anarquia e despotismo e não entrar nunca na ordem constitucional.

Assim, Constant não é um teórico do estado de exceção nem da prerrogativa régia concebida à maneira de Locke, ou seja, como uma margem de ação discricionária concedida ao Poder Executivo para agir em prol do bem público à margem das ou contra as leis existentes, tendo por freio a possibilidade da insurreição popular. A incorporação controlada do arbítrio pensada pelo autor franco-suíço ocorre por meio da decisão discricionária que participa do jogo político regular, sem se confundir com as atribuições dos poderes Executivo, Legislativo e Judiciário. O objeto teórico de Constant iluminado por esta tese não é o estado de exceção nem a margem de ação própria ao Executivo, mas a decisão entendida como dimensão incontornável do político, a qual não pertence exclusivamente a momentos excepcionais, mas também não pode ser apropriada pelos governantes, sob risco de deriva tirânica.

Desse modo, a contribuição teórica de Constant que esta tese procurou realçar se inscreve na reformulação do conceito de decisão política. Bernardi (2013) expõe dois modos estabelecidos de compreensão do conceito de decisão na teoria política. O primeiro compreende a decisão como escolha, segundo o paradigma da escolha racional, o qual tem no utilitarismo de Bentham uma de suas fontes históricas. O segundo compreende a decisão como comando, vontade autorizada a obrigar outras vontades - uma compreensão voluntarista da decisão que tem seu solo histórico nas teorias da soberania, e em Carl Schmitt sua maior encarnação no século XX. Bernardi coloca em questão essa polarização ao explorar, na compreensão da decisão como comando, as consequências da efetivação da decisão política como lei, criticando assim a concepção puramente voluntarista da decisão e a definição da política como poder unilateral de comandar.

Ao sublinhar o "decisionismo moderado" de Constant, esta tese propõe extrair da obra do autor um paradigma da decisão política original em relação aos dois modelos polarizados por Bernardi, destacando também a diferença de Constant em relação à concepção alternativa de decisão proposta pelo próprio autor contemporâneo. Ao longo da tese, pudemos acompanhar a crítica do autor franco-suíço, tanto às teorias da soberania como vontade absoluta e ilimitada autorizada a comandar (uma crítica que ele dirige primeiramente a Rousseau, remontando depois a raiz do equívoco à obra de Hobbes), como ao utilitarismo de Bentham, acusado de suprimir os direitos inalienáveis do indivíduo e seu senso de dever moral em nome do critério da utilidade. Em ambas as 
críticas, Constant ressalta o déficit moral desses dois paradigmas da decisão. Tanto a vontade soberana absoluta e ilimitada como o indivíduo maximizador de utilidade podem decidir sem levar em consideração os princípios morais considerados por ele como fundamentais. A decisão pregada por Constant tem, ao contrário, um fundamento ético bem estabelecido, confundindo-se, por vezes, com a própria noção de julgamento moral. Não obstante, o fundamento ético não retira da decisão constantiana seu caráter próprio, qual seja, o fato de não poder ser derivada de princípios fixos na base de um encadeamento lógico entre princípios universais e intermediários. É neste ponto que é fundamental sua teorização do sentimento religioso como fundamento da moral, insistindo no caráter não racionalizável desse sentimento íntimo. A inovação de Constant que estamos enfatizando consiste em atrelar a decisão a uma base moral, sem que essa base moral transforme a decisão em um encadeamento racional entre princípios universais e intermediários. A "espécie de imprecisão e de latitude moral" referida a respeito do bom exercício do direito de graça, mas também do julgamento realizado por jurados, é o paradigma por excelência dessa decisão moral que não pode se formalizar a ponto de se tornar um julgamento no sentido estrito da palavra - uma preocupação que Constant revela ao discutir o direito de graça nos Principes de politique de 1806 (cf. p. 191 supra).

Na discussão sobre a responsabilidade dos ministros, há uma passagem dessa decisão calcada no julgamento moral a uma decisão calcada no julgamento político. Não que os critérios morais deixem de ser levados em consideração: em certo sentido, a política teorizada por Constant, assim como por Staël, é indissociável da dimensão moral. No entanto, o autor franco-suíço se faz também um teórico da contingência política. Embora os critérios morais contem para a decisão do que fazer perante a contingência política, essa decisão não pode ser inteiramente determinada pela moral, muito menos subsumida por princípios fixos, sejam políticos ou morais, que façam abstração das circunstâncias específicas, as quais muitas vezes não se prestam à teorização abstrata. Em outras palavras, no pensamento de Constant, a política é indissociável da moral, mas não se subordina a ela.

Na discussão sobre o poder neutro, essa decisão compreendida como julgamento político já estava em jogo. O poder preservador é encarregado de julgar quando um poder constituído está se transformando em uma ameaça à Constituição e decidir discricionariamente quando é o momento de frear essa ameaça. Desse modo, sua 
atribuição básica é formular um bom julgamento da conjuntura política, orientado pelo valor básico da preservação da Constituição. Esse valor é o único sobre o qual o poder preservador não pode ser neutro, devendo se posicionar a favor da Constituição contra os partidos, interesses e opiniões que desejam subvertê-la. Após haver defendido, em sua juventude, a parcialidade republicana dos governantes da República, e haver sustentado, imediatamente após o 18 Frutidor, a centralização do poder nas mãos do partido republicano, com a teorização do poder neutro, a fidelidade aos valores constitucionais passa a ser garantida pela posição estrutural desse poder, não mais pela convicção ideológica de seus membros. É essa posição estrutural que leva a assembleia republicana vitalícia a defender a República, e o Rei, a defender a monarquia constitucional.

No âmbito da responsabilidade dos ministros, o julgamento político se torna mais difuso e mais cotidiano. Mais difuso, porque não há um único poder encarregado de julgar. Embora o centro do julgamento seja o tribunal formado pela Câmara dos Pares, o objetivo de Constant é envolver no processo o conjunto do edifício constitucional, mobilizando os cidadãos em escala individual. Mais cotidiano, porque não se trata de julgar as grandes ameaças à Constituição, mas de estender o crivo crítico à ação governamental dos diferentes ministérios. Como sugerido em De la responsabilité des ministres, o ideal de Constant é que os ministros sejam denunciados frequentemente, de modo que o exame crítico dos atos ministeriais entre no cotidiano da vida social, sem que isso resulte em uma proliferação de punições.

Distinta dos dois paradigmas da decisão expostos por Bernardi, a noção constantiana do julgamento político difere também do modelo de decisão proposto pelo autor contemporâneo, pois todo o seu raciocínio deriva das consequências da efetivação da decisão política como lei. Ora, a decisão com a qual Constant se preocupa não é a que institui a lei: ela está tão ausente do escopo do Poder Legislativo quanto do dos poderes Executivo e Judiciário. A decisão constantiana é aquela que preenche o vácuo deixado pela insuficiência da lei, seja essa insuficiência de ordem predominantemente moral ou política. É justamente essa ideia da decisão que precisa ocorrer à margem das ou contra as leis estabelecidas que aproxima a problemática de Constant da da prerrogativa lockeana, embora a resposta do autor franco-suíço seja radicalmente diferente da do filósofo inglês.

Teórico de um paradigma da decisão política cuja possibilidade de institucionalização é limitada, Constant figura nesta tese menos como um "pai fundador" 
do moderno Estado de Direito liberal do que como um revelador de suas antinomias constitutivas. Segundo Gauchet (2005, p. 281), a estabilização dos regimes representativos, na segunda metade do século XX, obedeceu ao espírito de instituições como o júri constitucional de Sieyès e o poder neutro de Constant. Como se sabe, o substituto contemporâneo das instituições propostas por Sieyès e Constant são as cortes constitucionais. "O controle constitucional forma o único desfiladeiro pelo qual é possível fazer passar a edificação desse terceiro poder tão problemático de estabelecer. Ele é o lugar geométrico em que as tensões relativas a sua construção se resolvem bem ou mal" (GAUCHET, 1995, p. 275). Entretanto, cabe se perguntar: o controle jurisdicional de constitucionalidade das leis realizado pelas cortes constitucionais contemporâneas responde de fato ao problema político que Constant buscava resolver? Ele substitui as diferentes modalidades de incorporação controlada do arbítrio tratadas nesta tese?

Em primeiro lugar, é notável como algumas das proposições de Constant só fazem sentido na ausência da instituição do controle de constitucionalidade. É a própria inexistência de um órgão encarregado de determinar quais leis ou ordens executivas são constitucionais e quais não são que torna aguda a necessidade do exame individual das leis, assim como do exame dos atos executivos por parte dos funcionários subalternos:

(...) vocês não podem manter sem restrições seu princípio de obediência passiva. (...). Vocês tampouco podem indicar com precisão cada circunstância em que a obediência deixa de ser um dever e se torna um crime. Dirão que qualquer ordem contrária à Constituição estabelecida não deve ser executada? Vocês são reconduzidos, apesar de si mesmos, para o exame do que é contrário à Constituição estabelecida. O exame é para vocês aquele palácio de Strigiline, ao qual os cavaleiros retornavam sem cessar, apesar de seus esforços para se afastar dele (CONSTANT, 1982, p. 398-399).

Em outras palavras, justamente por não haver uma autoridade capaz de dar a palavra final sobre a constitucionalidade das leis e atos governamentais, o indivíduo e o funcionário subalterno são encarregados de realizar esse julgamento por sua própria conta. Se o resultado desse livre exercício de sua razão os leva a um julgamento penal, este só pode ser realizado por jurados, vistos por Constant como os agentes de um julgamento discricionário que leva em consideração as circunstâncias morais não previstas na lei.

Em certo sentido, a consolidação das cortes constitucionais tornou possível sair do estado "anárquico" visto por Constant como o único legítimo perante a incerteza sobre a legitimidade e constitucionalidade de cada lei e ato governamental. Nas democracias contemporâneas, um indivíduo não pode desobedecer a uma lei por considerá-la 
inconstitucional: o juiz dessa suposta inconstitucionalidade da lei é a corte constitucional, inexistente no horizonte teórico de Constant. Todavia, o traço "anárquico" dos princípios de liberdade de nosso autor não é resolvido pelas disposições da democracia liberal contemporânea, apenas estabilizado constitucionalmente. Afinal, as cortes constitucionais também podem abusar de seu poder, invadir os outros poderes ou estabelecer decisões que causam mais insegurança do que segurança jurídica. ${ }^{130}$ Quando a dinâmica dos poderes constituídos gera inquietação política e incerteza sobre o bom cumprimento da Constituição, volta-se ao cenário constantiano, no qual é impossível se livrar da necessidade do exame individual. Assim, a insistência de Constant sobre o exame individual das leis (e sobre o exame das ordens ministeriais por parte dos agentes subalternos), com o grau de arbítrio intrínseco a esse julgamento extralegal, não é uma prefiguração das disposições da democracia liberal contemporânea, mas uma revelação sobre uma de suas antinomias fundamentais: necessário para impedir a tirania, o império da lei precisa de indivíduos dispostos a subverter a lei para que a liberdade não seja ameaçada. As sugestões de Constant a esse respeito são carregadas de tensões e empecilhos para sua tradução prática, a qual, se realizada literalmente, beiraria a anarquia completa e a dificuldade de efetivar qualquer lei. Por isso, seu interesse não reside no fornecimento de um modelo normativo para a aplicação das leis na contemporaneidade, mas no apontamento de antinomias que continuam fazendo parte de nossas democracias, mesmo após a estabilização referida por Gauchet.

$\mathrm{Se}$ as cortes constitucionais não resolvem satisfatoriamente o problema que Constant tinha em mente ao discutir a possibilidade de desobedecer às leis inconstitucionais ou ilegítimas, tampouco elas podem ser compreendidas como uma versão possível do poder neutro. Gauchet faz uma reflexão instigante sobre "a própria organização do processo representativo como processo reflexivo" (GAUCHET, 1995, 269), a qual esteve implícita na busca de um "metapoder" de 1789 às elaborações de

${ }^{130}$ Ver os apontamentos de Newton Bignotto sobre "os riscos que os excessos do poder judiciário fazem correr aos regimes livres" (BIGNOTTO, 2018, p. 429) - riscos subestimados pela tradição de pensamento político que, na esteira de Montesquieu e dos Federalistas americanos, sustentou a leitura segundo a qual "o poder judiciário por sua natureza é o mais fraco de todos, o menos capaz de usurpar as prerrogativas do legislativo e do executivo e que, por isso, é o mais apto a defender a Constituição contra seus inimigos e a servir de fiel da balança nas disputas que podem destruir o corpo político" (BIGNOTTO, 2018, p. 436). 
Constant, redundando nas cortes constitucionais contemporâneas. Contudo, essa aproximação entre o "terceiro poder" buscado durante a Revolução Francesa e as cortes constitucionais contemporâneas não leva em consideração o caráter necessariamente discricionário do poder neutro, o qual torna impossível sua absorção pelo Poder Judiciário - uma impossibilidade argumentada pelo próprio Constant. Encarregado de realizar um julgamento político, no qual a Constituição entra como um valor a ser defendido contra seus inimigos e não como uma norma a ser aplicada, o poder neutro se desvirtuaria se realizasse um julgamento jurisdicional. Mais uma vez, as reflexões de Constant sobre esse assunto não o situam como um profeta da democracia liberal contemporânea, mas antes como um possível crítico da tendência do arranjo institucional contemporâneo a suprimir o espaço necessário da decisão discricionária e a procurar resolver todos os conflitos pela via da judicialização - uma posição bem captada por Schmitt, quem se apropria de Constant, contra Kelsen, em $O$ guardião da Constituição. As aporias em que cai Constant a respeito da eficácia última do poder neutro e sobre a possibilidade ou não de prevenir seus abusos, apontadas por Gauchet (1995, p. 249) e comentadas no final do Capítulo 2 desta tese (cf. p. 154-155 supra), devem ser entendidas no mesmo sentido das dificuldades práticas da desobediência civil referidas há pouco: elas interessam por revelar uma aporia da democracia moderna (a invocação de um espaço para a decisão discricionária, sem que esse espaço possa ser ocupado sem perigo), não por fornecer um modelo normativo subjacente ao Estado liberal contemporâneo.

Revelador perspicaz das antinomias constitutivas do moderno Estado de Direito liberal, Constant deveria figurar entre as referências centrais do "retorno ao político" pregado por uma autora como Chantal Mouffe, quem atualiza a crítica de Schmitt à tendência do liberalismo a suprimir a esfera do político (MOUFFE, 1993). Se o objetivo é resgatar a esfera do político no quadro de democracias pluralistas, como é o caso de Mouffe, o "decisionismo moderado" de Constant é certamente mais seguro do que o decisionismo absoluto de Schmitt. Afinal, como nota Urfalino, "revela-se impossível transplantar o esquema schmittiano do político (...) para o coração da democracia liberal sem alguma acrobacia” (URFALINO, 2019, p. 308).

No entanto, os aspectos do pensamento de Constant ressaltados nesta tese vão além de uma simples incorporação do decisionismo schmittiano sem os riscos de deriva autoritária deste último. O que está em jogo, no Constant aqui apresentado, é a possibilidade de colocar uma modalidade temperada de decisionismo a serviço de uma 
centralidade reforçada do julgamento político. Segundo Urfalino, "o decisionismo implica a inanidade do julgamento político" (URFALINO, 2019, p. 309). Na concepção do autor contemporâneo, o decisionismo tem por base uma dicotomia entre duas opções igualmente insatisfatórias: "ou uma concepção racionalista da decisão que levaria a um determinismo lógico (...), ou uma concepção existencialista que preservaria a liberdade do agente que decide ao preço de abandonar sua racionalidade" (URFALINO, 2019, p. 302). O resultado dessa dicotomia, superada pelos trabalhos de Paul Ricœur e Vincent Descombes, ${ }^{131}$ seria o abandono do julgamento político, pois todo esforço de julgar os fatos políticos segundo regras ou princípios gerais seria equiparado a uma racionalidade absoluta e determinista que suprime qualquer espaço para a vontade e para a liberdade da ação (URFALINO, 2019, p. 309). Embora Constant tenha vivido em um contexto filosófico em que essa dicotomia, questionada apenas a partir de meados do século XX, ainda estava em curso (basta pensar nas proposições ultrarracionalistas de um Beccaria, de um Bentham ou de um Condorcet, ou mesmo na proposição inicial de Constant segundo a qual tudo que não fosse derivado de princípios teorizáveis seria sinônimo de arbítrio e tirania), ressaltamos nesta tese esforços teóricos seus que podem contribuir para superá-la, sem eclipsar o espaço necessário da decisão política. Afinal, o autor francosuíço reconhece, em vários momentos identificados nesta tese, a necessidade de decisões discricionárias que não derivem de princípios fixos, sem que esse reconhecimento da necessidade da decisão implique o culto da vontade que decide sem considerar os valores morais e as consequências políticas da ação. Em outras palavras, sua modalidade de decisionismo, ao contrário da criticada por Urfalino, não se coloca contra o julgamento político.

A teoria de Constant se encontra no cerne do julgamento político, tal como definido por Descombes, ou seja, "não como uma simples opinião sobre uma matéria política, mas como uma opinião dotada de consequências práticas para o sujeito que forma esse julgamento" (DESCOMBES, 2008, p. 9). Para Descombes, a especificidade do julgamento político reside em sua aplicação sobre um problema prático, e não teórico: sobre uma situação em que um ator político se pergunta o que fazer, diferente daquela em que um teórico pesquisa sobre a verdade, ou um ideólogo busca fundamentar sua visão de mundo na razão. O autor contemporâneo rejeita, como fundamentação desse

${ }^{131}$ RICOEUR, 1949; DESCOMBES, 2007; DESCOMBES, 2008. 
julgamento referente à ação prática, tanto o racionalismo, com sua busca exclusiva pela verdade teórica, como o decisionismo, com sua rejeição de qualquer justificação racional da ação para além da mera vontade e adesão a um partido. Quando Constant, por sua vez, trata as situações em que se faz necessário um julgamento político - principalmente no âmbito da responsabilidade dos ministros, mas também, como vimos, na esfera de ação do poder neutro, dos jurados, dos detentores do direito de graça e, no limite, na de cada indivíduo que se vê diante de uma lei considerada injusta -, o contraste não é estabelecido com a busca teórica da verdade ou com o engajamento político que recusa qualquer justificação racional, mas com um modelo do julgamento que, inspirado na obra de Beccaria, exige a aplicação exata da lei ou princípio geral ao caso particular. É, portanto, por meio da adesão a um "decisionismo moderado", crítico da utopia de uma lei ou princípio moral que se aplica ao mundo humano sem a mediação do julgamento, que Constant sublinha a centralidade do julgamento político. Mais precisamente, de um julgamento marcado por uma "espécie de imprecisão e de latitude moral". 


\section{Bibliografia}

AGUIAR, Thais Florencio de. Uma genealogia de princípios de demofilia em concepções utópicas de democratização. 2013. 361 f. Tese (Doutorado) - Curso de Ciência Política, Instituto de Estudos Sociais e Políticos da Universidade do Estado do Rio de Janeiro (IESP - UERJ), Rio de Janeiro, 2013.

AMBROSINI, Diego Rafael. Do Poder Moderador: Uma análise da organização do poder na construção do Estado imperial brasileiro. 2004. 137 f. Dissertação (Mestrado) Curso de Ciência Política, Departamento de Ciência Política, Universidade de São Paulo, São Paulo, 2004.

ARISTOTLE. Politics. Indianapolis/Cambridge: Hacket Publishing Company, 1998.

ARENDT, Hannah. Crises da República. São Paulo: Perspectiva, 2008.

AUBENQUE, Pierre. La prudence chez Aristote. Paris: Presses Universitaires de France, 1997.

BACZKO, Bronislaw. Comment sortir de la Terreur? Thermidor et Révolution. Paris: Gallimard, 1989a.

BACZKO, Bronislaw. "Monstres sanguinaires" et "circonstances fatales": Les discours thermidoriens sur la Terreur. In: FURET, François; OZOUF, Mona (Org.). The French Revolution and the Creation of Modern Political Culture. Volume 3: The transformation of political culture 1789-1848. Oxford...: Pergamon Press, 1989b.

BAKER, Keith Michael. Inventing the French Revolution: Essays on French Political Culture in the Eighteenth Century. Cambridge: Cambridge University Press, 1990.

BAKER, Keith Michael. Introduction. In: BAKER, Keith Michael (Org.). The French Revolution and the Creation of Modern Political Culture. Volume 4: The Terror. Oxford...: Pergamon Press, 1994.

BARBERIS, Mauro. Thermidor, le libéralisme et la modernité politique. In: DUPUY, Roger; MORABITO, Marcel (Org.). 1795: Pour une République sans Révolution. Rennes: Presses Universitaires de Rennes, 1996. 
BARBERIS, Mauro. Des effets de la Terreur - Introduction. In: CONSTANT, Benjamin. Cuvres Complètes. I: Écrits de jeunesse (1774-1799). Volume dirigé par Lucia Omacini et Jean-Daniel Candaux. Textes établis et annotés par Mauro Barberis (...). Tübingen: Max Niemeyer Verlag, 1998a.

BARBERIS, Mauro. A Charles His - Introduction. In: CONSTANT, Benjamin. Euvres Complètes. I: Écrits de jeunesse (1774-1799). Volume dirigé par Lucia Omacini et JeanDaniel Candaux. Textes établis et annotés par Mauro Barberis (...). Tübingen: Max Niemeyer Verlag, 1998 b.

BARBERIS, Mauro. Introduction. In: CONSTANT, Benjamin. Euvres Complètes. II: De la justice politique (1798-1800), d'après « Enquiry Concerning Political Justice » de William Godwin. Volume dirigé par Lucia Omacini et Étienne Hofmann. Textes établis et annotés par Laura Saggiorato. Introductions de Mauro Barberis et Laura Saggiorato. Tübingen: Max Niemeyer Verlag, 1998c.

BECCARIA, Marquis Cesare Bonesana. Des délits et des peines. Paris: Institut Coppet, 2011.

BENTHAM, Jérémie. Traités de législation civile et pénale: Ouvrage extrait des manuscrits de M. Jérémie Bentham, jurisconsulte anglais; par Ét. Dumont, membre du conseil représentatif de Génève. Paris: Rey et Gravier, Libraires, 1830.

BENTON, Robert J. Political Expediency and Lying: Kant vs Benjamin Constant. Journal of the History of Ideas, v. 43, n. 1, p. 135-144, 1982.

BERLIN, Isaiah. Liberty: Incorporating Four Essays on Liberty. Oxford: Oxford University Press, 2002.

BERNARDI, Bruno. Qu'est-ce qu'une décision politique? Paris: Librairie Philosophique J. Vrin, 2013.

BIANCHI, Álvaro. O que é um golpe de Estado? 2016. Disponível em: $<$ http://blogjunho.com.br/o-que-e-um-golpe-de-estado/>. Acesso em: 31 jul. 2019.

BIGNOTTO, Newton. Soberania e exceção no pensamento de Carl Schmitt. Kriterion, n. 118, p. 401-415, dez. 2008.

BIGNOTTO, Newton. O impossível equilíbrio entre os poderes e a judicialização da política. Síntese: Revista de Filosofia [S.L.], v. 45, n. 143, p. 423-440, 21 dez. 2018. 
BINOCHE, Bertrand. La raison sans l'Histoire: Échantillons pour une histoire comparée des philosophies de l'Histoire. Paris: Presses Universitaires de France, 2007.

BONAPARTE, Napoléon. Correspondance générale. Tome I: Les apprentissages, 1784-1797. Volume placé sous la direction de Thierry Lentz, assisté d’Émile Barthet et de François Houdecek. Paris: Fayard, 2004.

BRAHAMI, Frédéric. La Raison du Peuple: Un héritage de la Révolution française (1789-1848). Paris: Les Belles Lettres, 2016.

BREDIN, Jean-Denis. Emmanuel Sieyès et Jacques Necker. Annales Benjamin Constant, 23-24, p. 63-88, 2000.

BROWN, Howard. Ending the French Revolution: Violence, Justice and Repression from the Terror to Napoleon. Charlottesville/Londres: University of Virginia Press, 2006. BURNAND, Léonard. Benjamin Constant et l'interprétation de la Terreur. Annales Benjamin Constant, 35, p. 43-55, 2010.

CABANIS, Pierre-Jean-Georges. Quelques considérations sur l'organisation sociale en général, et particulièrement sur la nouvelle Constitution. Corps Législatif: Commission du Conseil des Cinq-Cents. Paris: De l'Imprimerie Nationale, An VIII.

CAMPOS, Gabriel Afonso. Poder Neutro e razão de Estado em Benjamin Constant. Revista de Ciências do Estado, v. 4, n. 1, p. 1-20, 2019.

CANTO-SPERBER, Monique. Philosophie morale: Les grandes doctrines de la philosophie morale. In: RAYNAULD, Philippe; RIALS, Stéphane. Dictionnaire de philosophie politique. Paris: Presses Universitaires de France, 2005. p. 551-560.

CASSIMIRO, Paulo Henrique Paschoeto. O Abismo do Tempo: História, Liberalismo e Democracia no Pensamento Político Francês (1789-1848). 2016. 280 f. Tese (Doutorado) - Curso de Ciência Política, Instituto de Estudos Sociais e Políticos da Universidade do Estado do Rio de Janeiro (IESP - UERJ), Rio de Janeiro, 2016.

CASSON, Douglas. Emergency Judgment: Carl Schmitt, John Locke and the Paradox of Prerogative. Politics \& Policy, v. 35, n. 6, p. 944-971, 2008.

CHANIAL, Philippe. Les libéralismes français anti-utilitaristes: G. de Staël (1766-1817), B. Constant (1767-1830) et A. de Tocqueville (1805-1859). In: CAILLÉ, Alain; 
LAZZERI, Christian; SENELLART, Michel (Org.). Histoire raisonnée de la philosophie morale et politique. Paris: La Découverte, 2001.

CHAPPEY, Jean-Luc. Pierre-Louis Roederer et la presse sous le Directoire et le Consulat: L'opinion publique et les enjeux d'une politique éditoriale. Annales historiques de la Révolution française, 334, dez. 2003.

CHATEAUBRIAND, François-René, vicomte de. De la Monarchie selon la Charte. Paris: Imprimerie de le Normant, 1816.

CHRISTOFFERSON, Michael Scott. French Intellectuals against the Left: The Antitotalitarian moment of the 1970s. Nova York/Oxford: Berghahn Books, 2004.

CLERMONT-TONNERRE, Stanislas de. Analyse raisonnée de la Constitution française. Paris, 1791.

CONDORCET. Guvres de Condorcet. Tome X. Paris: Firmin Didot Frères, Librairies, 1847.

CONSTANT, Benjamin. Réflexions sur les constitutions, la distribution des pouvoirs et les garanties, dans une monarchie constitutionnelle. Paris: De l'imprimerie de Hocquet, 1814.

CONSTANT, Benjamin. De la religion, considérée dans sa source, ses formes et ses développements. Tome I. Paris: Firmin Didot, 1824.

CONSTANT, Benjamin. Écrits et discours politiques. Présentation, notes et commentaires par O. Pozzo di Borgo. Paris: Jean-Jacques Pauvert, 1964.

CONSTANT, Benjamin. Les « Principes de politique » de Benjamin Constant. Publié par Étienne Hofmann. Tome II: Texte établi d'après les manuscrits de Lausanne et de Paris avec une introduction et des notes. Genebra: Droz, 1980.

CONSTANT, Benjamin. Cours de politique constitutionnelle. I. Genebra/Paris: Slatkine, 1982.

CONSTANT, Benjamin. Da liberdade dos antigos comparada à dos modernos. Revista Filosofia Política, n. 2, p. 1-7, 1985. 
CONSTANT, Benjamin. De la force du gouvernement actuel de la France et de la nécessité de s'y rallier (1796). Des réactions politiques. Des effets de la Terreur (1797). Préface et notes de Philippe Raynaud. Paris: Flammarion, 1988.

CONSTANT, Benjamin. Positions de combat à la veille de Juillet 1830: Articles publiés dans le Temps 1829-1830. Texte établi, annoté et commenté par Ephraïm Harpaz. Paris/Genebra: Champion/Slatkine, 1989.

CONSTANT, Benjamin. Fragments d'un ouvrage abandonné sur la possibilité d'une constitution républicaine dans un grand pays. Édition établie par Henri Grange. Paris: Aubier, 1991.

CONSTANT, Benjamin. Portraits, Mémoires, Souvenirs. Textes établis et annotés par Éphraïm Harpaz. Paris: Librairie Honoré Champion, 1992.

CONSTANT, Benjamin. Guvres Complètes: Correspondance générale. I: 1774-1792. Tübingen: Max Niemeyer Verlag, 1993.

CONSTANT, Benjamin. Écrits politiques. Textes choisis, présentés et annotés par Marcel Gauchet. Paris: Gallimard, 1997.

CONSTANT, Benjamin. Guvres Complètes. I: Écrits de jeunesse (1774-1799). Volume dirigé par Lucia Omacini et Jean-Daniel Candaux. Textes établis et annotés par Mauro Barberis (...). Tübingen: Max Niemeyer Verlag, 1998a.

CONSTANT, Benjamin. Euvres Complètes. II: De la justice politique (1798-1800), d'après « Enquiry Concerning Political Justice » de William Godwin. Volume dirigé par Lucia Omacini et Étienne Hofmann. Textes établis et annotés par Laura Saggiorato. Introductions de Mauro Barberis et Laura Saggiorato. Tübingen: Max Niemeyer Verlag, 1998b.

CONSTANT, Benjamin. Euvres Complètes: Correspondance générale. II: 1793-1794. Tübingen: Max Niemeyer Verlag, 1998c.

CONSTANT, Benjamin. Euvres Complètes. IX: Principes de politique et autres écrits (juin 1814 - juillet 1815). Volume dirigé par Olivier Devaux et Kurt Kloocke. Établissement des textes, notes et notices par André Cabanis (...). Tübingen: Max Niemeyer Verlag, 2001. 
CONSTANT, Benjamin. Euvres Complètes. IV: Discours au Tribunat et De la possibilité d'une constitution républicaine dans un grand pays. Volume dirigé par Maria Luisa Sánchez Mejía et Kurt Kloocke. Établissement des textes, introductions et notes par Boris Anelli (...). Tübingen: Max Niemeyer Verlag, 2005a.

CONSTANT, Benjamin. Euvres Complètes. VII: Journal intime (1811-1816) ; Carnet ; Livres de dépenses. Volume dirigé par Paul Delbouille et Kurt Kloocke. Textes établis et annotés par Paul Delbouille et Kurt Kloocke ; avec la collaboration d'Axel Blaeschke... Tübingen: Max Niemeyer Verlag, 2005b.

CONSTANT, Benjamin. Adolphe. Le Cahier rouge. Cécile. Édition d'Alfred Roulin. Paris: Gallimard, 2005c.

CONSTANT, Benjamin. Euvres Complètes. VIII: Florestan; De l'esprit de conquête et de l'usurpation; Réflexions sur les constitutions: 1813-1814. Volume dirigé par Kurt Kloocke et Béatrice Fink. Tübingen: Max Niemeyer Verlag, 2005d.

CONSTANT, Benjamin. Euvres Complètes. X: Textes politiques de 1815 à 1817. Volume dirigé par Kurt Kloocke. Établissement des textes, introductions, notes et notices par Francis Balace (...). Berlim: De Gruyter, 2010.

COSER, Ivo. Dois Conceitos de Liberdade: 60 anos após a sua publicação. Revista Brasileira de Ciências Sociais, v. 34, n. 100, p. 1-21, 2019.

CRAIUTU, Aurelian. A Virtue for Courageous Minds: Moderation in French Political Thought, 1748-1830. Princeton/Oxford: Princeton University Press, 2012.

DESCOMBES, Vincent. Le raisonemment de l'ours et autres essais de philosophie pratique. Paris: Seuil, 2007.

DESCOMBES, Vincent. Philosophie du jugement politique: Débat avec Vincent Descombes. Paris: Points essais, 2008.

DIJN, Annelien de. French Political Thought from Montesquieu to Tocqueville: Liberty in a Levelled Society? Cambridge: Cambridge University Press, 2008.

DUNN, John. The political thought of John Locke: An historical account of the argument of the 'Two Treatises of Government'. Cambridge: Cambridge University Press, 1969. 
FALCÃO, Luís. Benjamin Constant: os Princípios e as Repúblicas. Leviathan Cadernos de Pesquisa Política, n. 3, p. 190-221, 2011.

FATOVIC, Clement. Constitutionalism and Contingency: Locke's Theory of Prerogative. History of Political Thought, v. 25, n. 2, p. 276-297, 2004.

FLORENZANO, Modesto. Da força sempre atual do pensamento de Benjamin Constant e da necessidade de reconhecê-lo. Revista de História, 145, p. 167-179, 2001.

FONTANA, Biancamaria. Benjamin Constant and the post-revolutionary mind. New Haven/Londres: Yale University Press, 1991.

FONTANA, Biancamaria. The Thermidorian republic and its principles. In: FONTANA, Biancamaria (Org.). The invention of the modern republic. Cambridge: Cambridge University Press, 1994.

FONTANA, Biancamaria. Germaine de Staël: A political portrait. Princeton/Oxford: Princeton University Press, 2016.

FURET, François. Une polémique thermidorienne sur la Terreur: Autour de Benjamin Constant. Passé Présent, 2, p. 44-55, 1983.

FURET, François. La Terreur sous le Directoire. In: FURET, François; OZOUF, Mona (Org.). The French Revolution and the Creation of Modern Political Culture. Volume 3: The transformation of political culture 1789-1848. Oxford...: Pergamon Press, 1989.

FURET, François; HALÉVI, Ran. La Monarchie Républicaine: La Constitution de 1791. Paris: Fayard, 1996.

GACH. Des vices de l'institution du jury en France. Paris, 1804.

GARSTEN, Bryan. Religion and the Case against Ancient Liberty: Benjamin Constant's Other Lectures. Political Theory, 38(1), p. 4-33, 2010.

GAUCHET, Marcel. Constant. In: FURET, François; OZOUF, Mona. Dictionnaire critique de la Révolution française. Paris: Flammarion, 1988.

GAUCHET, Marcel. Constant, Staël et la Révolution française. In: FURET, François; OZOUF, Mona (Org.). The French Revolution and the Creation of Modern Political 
Culture. Vol. 3: The transformation of political culture 1789-1848. Oxford/Nova York: Pergamon, 1989.

GAUCHET, Marcel. La droite et la gauche. In: NORA, Pierre (Org.). Les lieux de mémoire. III: Les France. 1: Conflits et partages. Paris: Gallimard, 1992.

GAUCHET, Marcel. La Révolution des pouvoirs: La souveraineté, le peuple et la représentation. Paris: Gallimard, 1995.

GAUCHET, Marcel. Benjamin Constant: l'illusion lucide du libéralisme. In: CONSTANT, Benjamin. Écrits politiques. Textes choisis, présentés et annotés par Marcel Gauchet. Paris: Gallimard, 1997.

GAUCHET, Marcel. La condition politique. Paris: Gallimard, 2005.

GAUCHET, Marcel. Necker. In: FURET, François; OZOUF, Mona. Dictionnaire critique de la Révolution française. Tome 2: Acteurs. Paris: Flammarion, 2017.

GAUCHET, Marcel. Robespierre: L'homme qui nous divise le plus. Paris: Gallimard, 2018.

GHELERE, Gabriela Doll. A liberdade individual para Benjamin Constant. 2008. 80 f. Dissertação (Mestrado) - Curso de Filosofia, Departamento de Filosofia, Universidade de São Paulo, São Paulo, 2008.

GODECHOT, Jacques; FAUPIN, Hervé (Org.). Les constitutions de la France depuis 1789. Paris: Flammarion, 2018.

GRANGE, Henri. Introduction. In: CONSTANT, Benjamin. Fragments d'un ouvrage abandonné sur la possibilité d'une constitution républicaine dans un grand pays. Édition établie par Henri Grange. Paris: Aubier, 1991.

GUENIFFEY, Patrice. La politique de la Terreur: Essai sur la violence révolutionnaire 1789-1794. Paris: Fayard, 2000.

GUENIFFEY, Patrice. Le Dix-huit Brumaire: L’épilogue de la Révolution française (910 novembre 1799). Paris: Gallimard, 2008.

GUENIFFEY, Patrice. Histoires de la Révolution et de l'Empire. Paris: Perrin, 2011. GUIZOT, François. Du gouvernement représentatif et de l'état actuel de la France. Paris: Chez Maradan, Librairie, 1816. 
GUIZOT, François. Du gouvernement de la France depuis la Restauration et du ministère actuel. Paris: À la Librairie Française de Ladvocat, Éditeur des Fastes de la Gloire, 1820.

GUTIERREZ, Benjamin J. Problematizing Executive Prerogative in Locke and Rousseau. 2011. 62 f. Tese (Doutorado) - Master of Arts, Department of Political Science, The University of Texas at El Paso, El Paso, 2011.

HALPÉRIN, Jean-Louis. Bentham, Jeremy (1748-1832). In: CAYLA, Olivier; HALPÉRIN, Jean-Louis. Dictionnaire des grandes œuvres juridiques. Paris: Dalloz, 2008 .

HOBBES, Thomas. Leviatã, ou matéria, forma e poder de uma República eclesiástica e civil. São Paulo: Martins Fontes, 2003.

HOLMES, Stephen. Benjamin Constant and the Making of Modern Liberalism. New Haven/Londres: Yale University Press, 1984.

JAINCHILL, Andrew. Reimagining Politics after the Terror: The Republican Origins of French Liberalism. Ithaca/Londres: Cornell University Press, 2008.

JAUME, Lucien. L'individu effacé, ou le paradoxe du libéralisme français. Paris: Fayard, 1997.

JAUME, Lucien. Le concept de « responsabilité des ministres » chez Benjamin Constant. Revue française de droit constitutionnel, n. 42, p. 227-243, 2000a.

JAUME, Lucien. Coppet, creuset du libéralisme comme « culture morale ». In: JAUME, Lucien (Org.). Coppet, creuset de l'esprit libéral: Les idées politiques et constitutionnelles du groupe de Madame de Staël. Aix-en-Provence/Paris: Presses Universitaires d'Aix-Marseille/Economica, 2000b.

JAUME, Lucien. De la responsabilité des ministres - Introduction. In: CONSTANT, Benjamin. Euvres Complètes. IX: Principes de politique et autres écrits (juin 1814 juillet 1815). Volume dirigé par Olivier Devaux et Kurt Kloocke. Établissement des textes, notes et notices par André Cabanis (...). Tübingen: Max Niemeyer Verlag, 2001. T. I.

JAUME, Lucien. Sieyès et le sens du jury constitutionnaire: une réinterprétation. Historia Constitucional (revista electrónica), n. 3, 2002. 
JAUME, Lucien. Naissance du libéralisme et interprétations de la Charte. Jus Politicum, $\mathrm{n}^{\circ}$ 13, s.d. Disponível em: http://juspoliticum.com/article/Naissance-du-liberalisme-etinterpretations-de-la-Charte-929.html. Acesso em: 14 mar. 2020.

JENNINGS, Jeremy. The return of the political? New French journals in the history of political thought. History of Political Thought, v. 18, n. 1, p. 148-156, 1997.

KAHAN, Alan. Limited Government, Unlimited Liberalism: Or, How Benjamin Constant was a Kantian after all. 2018. Disponível em: <https://oll.libertyfund.org/pages/lm-constant>. Acesso em: 04 out. 2019.

KALYVAS, Andreas; KATZNELSON, Ira. Liberal beginnings: making a republic for the moderns. Cambridge: Cambridge University Press, 2008.

KANT, Emmanuel. Sur l'expression courante: il se peut que ce soit juste en théorie, mais en pratique cela ne vaut rien. Sur un prétendu droit de mentir par humanité. Paris: Librairie Philosophique J. Vrin, 1967.

KANT, Immanuel. Metafísica dos Costumes. Petrópolis/Bragança Paulista: Vozes/Editora Universitária São Francisco, 2013.

KERVÉGAN, Jean-François. État d'exception. In: RAYNAULD, Philippe; RIALS, Stéphane. Dictionnaire de philosophie politique. Paris: Presses Universitaires de France, 2005. p. 252-255.

KLOOCKE, Kurt. Benjamin Constant: une biographie intellectuelle. Genebra/Paris: Librairie Droz, 1984.

LAQUIÈZE, Alain. Le modèle anglais et la responsabilité ministérielle selon le Groupe de Coppet. In: JAUME, Lucien (Org.). Coppet, creuset de l'esprit libéral: Les idées politiques et constitutionnelles du groupe de Madame de Staël. Aix-en-Provence/Paris: Presses Universitaires d'Aix-Marseille/Economica, 2000.

LAQUIÈZE, Alain. Les origines du régime parlementaire en France (1814-1848). Paris: Presses Universitaires de France, 2002.

LAQUIÈZE, Alain. État d'exception et coup d'État dans la pensée du Groupe de Coppet. Annales Benjamin Constant, n. 27, Genebra, 2003. 
LEE, James. Benjamin Constant: the moralization of modern liberty. 2003. $333 \mathrm{f}$. Tese (Doutorado) - Curso de Philosophy, University of Wisconsin-Madison, Madison, 2003. LEZAY, Adrien. Qu'est-ce que la Constitution de 95? Paris, 1795.

LEZAY, Adrien. De la faiblesse d'un gouvernement qui commence, et de la nécessité où il est de se rallier à la majorité nationale. Paris, 1796.

LEZAY, Adrien. Des causes de la Révolution et de ses résultats. Paris, 1797.

LILLA, Mark. The Other Velvet Revolution: Continental Liberalism and its Discontents. Daedalus, v. 123, n. 2, p. 129-157, 1994.

LOCKE, John. Dois tratados sobre o governo. São Paulo: Martins Fontes, 2005.

LYNCH, Christian Edward Cyril. O momento monarquiano: O Poder Moderador e o pensamento político imperial. 2007. 421 f. Tese (Doutorado) - Curso de Ciência Política, Instituto Universitário de Pesquisas do Rio de Janeiro (IUPERJ), Rio de Janeiro, 2007.

LYNCH, Christian Edward Cyril. A democracia como problema: Pierre Rosanvallon e a escola francesa do político. In: ROSANVALLON, Pierre. Por uma história do político. São Paulo: Alameda, 2010.

LYNCH, Christian Edward Cyril. Fundações do pensamento político brasileiro. Rio de Janeiro: Topbooks, 2020. No prelo.

MABLY. Guvres complètes de l'abbé de Mably. T. IX. Lyon: Chez J. B. Delamolliere, 1792.

MAISTRE, Joseph de. Considérations sur la France. Suivi d'Essai sur le principe générateur des constitutions politiques. Présentation de Pierre Manent. Bruxelas: Éd. Complexe, 1988.

MAISTRE, Joseph de. De la souveraineté du peuple: Un anti-contrat social. Texte établi, présenté et annoté par Jean-Louis Darcel. Paris: Presses Universitaires de France, 1992.

MANENT, Pierre. Aux origines du libéralisme: Benjamin Constant. Commentaire, v. 3, n. 11, p. 483-491, 1980.

MANENT, Pierre. Histoire intellectuelle du libéralisme. Paris: Librairie Arthème Fayard/Pluriel, 2012. 
MAQUIAVEL, Nicolau. Discursos sobre a primeira década de Tito Lívio. São Paulo: Martins Fontes, 2007.

MATHIEZ, Albert. Saint-Simon, Lauraguais, Barras, Benjamin Constant, etc. et la Réforme de la Constitution de l'an III après le Coup d'Etat du 18 fructidor an V. Annales historiques de la Révolution française, n. 31, p. 5-23, 1929.

MIGNEAUX, Marchais de. De la responsabilité des ministres: Observations sur la proposition de loi à ce sujet, faite à la Chambre des pairs, par M. le comte de LallyTollendal, et sur quelques opinions de M. Benjamin Constant. Paris: Lhuilier, 1817.

MONTESQUIEU, Charles de Secondat, Baron de. O espírito das leis. São Paulo: Martins Fontes, 2005.

MORABITO, Marcel. Les nouveautés constitutionnelles de l'an III. In: DUPUY, Roger; MORABITO, Marcel (Org.). 1795: Pour une République sans Révolution. Rennes: Presses Universitaires de Rennes, 1996.

MOUFFE, Chantal. The return of the political. Londres/Nova York: Verso, 1993.

NAUDÉ, Gabriel. Considérations politiques sur les coups d'État. 1667.

NECKER, Jacques. Du Pouvoir Exécutif dans les Grands États. 1792.

NECKER, Jacques. De la Révolution française. Paris: Maret, an V (1797).

NECKER, Jacques. Euvres complètes de M. Necker. Publiés par M. le baron de Staël, son petit-fils. Tome XI. Paris, 1821.

NICOLETE, Roberta K. Soromenho. De Reims a Varennes: As linguagens da autoridade política na França revolucionária. 2017. 212 f. Tese (Doutorado em Ciência Política) - Faculdade de Filosofia, Letras e Ciências Humanas, Universidade de São Paulo, São Paulo, 2017.

OSTRENSKY, Eunice. Maquiavel: a ambição e o dilema das leis agrárias. Lua Nova, n. 107, p. 55-90, 2019.

OZOUF, Mona. The Terror after the Terror: An Immediate History. In: BAKER, Keith Michael (Org.). The French Revolution and the Creation of Modern Political Culture. Volume 4: The Terror. Oxford...: Pergamon Press, 1994. 
OZOUF, Mona. Les décrets des deux-tiers ou les leçons de l'Histoire. In DUPUY, Roger; MORABITO, Marcel (Org.). 1795: Pour une République sans Révolution. Rennes: Presses Universitaires de Rennes, 1996.

PASQUINO, Pasquale. Gardien de la Constitution ou justice constitutionnelle ? Carl Schmitt et Hans Kelsen. In: TROPER, Michel; JAUME, Lucien (Org.). 1789 et l'invention de la Constitution. Actes du colloque de Paris organisé par l'Association Française de Science Politique: 2, 3 et 4 mars 1989. Paris: Bruylant, 1994a.

PASQUINO, Pasquale. The constitutional republicanism of Emmanuel Sieyès. In: FONTANA, Biancamaria (Org.). The invention of the modern republic. Cambridge: Cambridge University Press, 1994b.

PASQUINO, Pasquale. Locke on King's Prerogative. Political Theory, v. 26, n. 2, p. 198-208, 1998.

PETTIT, Philip. Republicanism: A Theory of Freedom and Government. Nova York: Oxford University Press, 1997.

PORRET, Michel. Voltaire et le droit de punir: Un activiste du moment Beccaria. Revue d'Histoire Moderne \& Contemporaine, n. 63-3, p. 88-109, 2016.

PRANCHÈRE, Jean-Yves. L'autorité contre les Lumières: La philosophie de Joseph de Maistre. Genebra: Droz, 2004.

RADEMACHER, Ingrid. La science sociale républicaine de Pierre-Louis Roederer. Revue Française d'Histoire des Idées Politiques, n. 13, 2001.

RAYNAUD, Philippe. Préface. In: CONSTANT, Benjamin. De la force du gouvernement actuel de la France et de la nécessité de s'y rallier (1796). Des réactions politiques. Des effets de la Terreur (1797). Préface et notes de Philippe Raynaud. Paris: Flammarion, 1988.

RAYNAUD, Philippe. Benjamin Constant et Germaine de Staël: Infortunes de l'amour et sacralité de la liberté. In: GUENIFFEY, Patrice; MEAUX, Lorraine de (Org.). Les couples illustres de l'histoire de France. Paris: Le Figaro Histoire/Perrin, 2017.

RIALS, Stéphane. Révolution et contre-révolution au XIXe siècle. Paris: Éditions Albatros et D.U.C., 1987. 
RICHET, Denis. Coups d'État. In: FURET, François; OZOUF, Mona. Dictionnaire critique de la Révolution française. Paris: Flammarion, 1988.

RICEUR, Paul. La philosophie de la volonté. Tome 1: Le volontaire et l'involontaire. Paris: Aubier/Ed. Montaigne, 1949.

ROBESPIERRE, Maximilien. Guvres de Maximilien Robespierre. Tome III. Paris, 1840.

ROEDERER, Pierre-Louis. Du Gouvernement. Paris, 1795.

ROEDERER, Pierre-Louis. Journal d'économie publique, de morale et de politique. Paris, 1796-1797.

ROEDERER, Pierre-Louis. Guvres du Comte P.-L. Roederer. Paris: Firmin-Didot frères, 1853-1859, 8 vol.

ROSANVALLON, Pierre. Le moment Guizot. Paris: Gallimard, 1985.

ROSANVALLON, Pierre. Pour une histoire conceptuelle du politique (note de travail). Revue de synthèse, IV, n. 1-2, p. 93-105, 1986.

ROSANVALLON, Pierre. La monarchie impossible: Les Chartes de 1814 et de 1830. Paris: Fayard, 1994.

ROSANVALLON, Pierre. Le modèle politique français: La société civile contre le jacobinisme de 1789 à nos jours. Paris: Éditions du Seuil, 2004.

ROSANVALLON, Pierre. Le bon gouvernement. Paris: Éditions du Seuil, 2015.

ROSENBLATT, Helena. Why Constant? A Critical Overview of the Constant Revival. CUNY Academic Works. 2004. Disponível em: <https://academicworks.cuny.edu/gc_pubs/222/>. Acesso em: 28 out. 2019.

ROSENBLATT, Helena. Madame de Staël, the Protestant Reformation, and the history of 'private judgement'. Annales Benjamin Constant, 31-32, p. 143-154, 2007.

ROSENBLATT, Helena. Liberal Values: Benjamin Constant and the Politics of Religion. Cambridge: Cambridge University Press, 2008.

ROUSSEAU, Jean-Jacques. Euvres complètes. III: Du Contrat Social, Écrits politiques. Sous la direction de Bernard Gagnebin et Marcel Raymond. Paris: Gallimard, 1964. 
ROUSSEAU, Jean-Jacques. O contrato social: Princípios do direito político. São Paulo: Martins Fontes, 2006.

RUNCIMAN, David. Coronavirus has not suspended politics: it has revealed the nature of power. 2020.2 Disponível em: https://www.theguardian.com/commentisfree/2020/mar/27/coronavirus-politicslockdown-hobbes?CMP=share_btn_fb. Acesso em: 27 mar. 2020.

SCHMITT, Carl. Political Theology: Four Chapters on the Concept of Sovereignty. Chicago/Londres: The University of Chicago Press, 2005.

SCHMITT, Carl. The concept of the political: Expanded edition. Chicago/Londres: University of Chicago Press, 2007.

SCHMITT, Carl. Dictatorship: From the Beginning of the Modern Concept of Sovereignty to the Proletarian Class Struggle. Cambridge: Polity Press, 2014.

SCHMITT, Carl. The guardian of the constitution. In: VINX, Lars (Org.). The Guardian of the Constitution: Hans Kelsen and Carl Schmitt on the limits of constitutional law. Cambridge: Cambridge University Press, 2015.

SHKLAR, Judith N. Books in Review: DE LA JUSTICE POLITIQUE by William Godwin, tr. by Benjamin Constant, edited by Burton R. Pollin. Quebec: Les Presses de l'Université Laval/Albany: State University of New York Press, 1972. Pp. 393. \$12.50. Political Theory, v. 1, n. 4, p. 486-488, 1973.

SIEYÈS, Emmanuel-Joseph. Des manuscrits de Sieyès 1773-1799. Sous la direction de Christine Fauré; avec la collaboration de Jacques Guilhaumou et Jacques Valier. Paris: Honoré Champion, 1999.

SKINNER, Quentin. The Foundations of Modern Political Thought. Volume 1: The Renaissance. Cambridge: Cambridge University Press, 1978.

SKINNER, Quentin. Liberty before Liberalism. Cambridge: Cambridge University Press, 1998.

SKINNER, Quentin. Visions of Politics. Volume I: Regarding Method. Cambridge: Cambridge University Press, 2002a. 
SKINNER, Quentin. A third concept of liberty. Proceedings of the British Academy, 117 , p. 237-268, 2002b.

STAËL, Madame de. De l'Allemagne. Paris: Garnier Frères, Libraires-Éditeurs, s.d.

STAËL, Anne-Louise-Germaine de. Des circonstances actuelles et autres essais politiques sous la Révolution. Sous la direction de Lucia Omacini. Paris: Honoré Champion, 2009.

STAROBINSKI, Jean. Benjamin Constant: la pensée du progrès et l'analyse des réactions. Annales Benjamin Constant, 23-24, p. 39-62, 2000.

SUANZES, Joaquín Varela. La monarquia en el pensamiento de Benjamin Constant (Inglaterra como modelo). Revista del Centro de Estudios Constitucionales, n. 10, p. 121-138, 1991.

THOREAU, Henry David. A Desobediência Civil. Porto Alegre: L\&PM, 2007.

TOCQUEVILLE, Alexis de. Cuvres. t. III. Paris: La Pléiade/Gallimard, 2004.

TOCQUEVILlE, Alexis de. A Democracia na América. Livro I: Leis e costumes. São Paulo: Martins Fontes, 2005.

TODOROV, Tzvetan. Benjamin Constant: La passion démocratique. Paris: Hachette Littératures, 1997.

TROPER, Michel. Terminer la Révolution: La Constitution de 1795. Paris: Fayard, 2006.

URFALINO, Philippe. Un nouveau décisionnisme politique: La philosophie du populisme de gauche. Archives de philosophie, v. 82, n. 2, p. 291-312, 2019.

VILlEMAIN, Abel-François. Le Roi, la Charte et la Monarchie. Paris: De l'imprimerie de Firmin Didot, 1816.

VINCENT, K. Steven. Benjamin Constant, the French Revolution, and the Origins of French Romantic Liberalism. French Historical Studies, v. 23, n. 4, p. 607-637, 2000.

VINX, Lars (Org.). The Guardian of the Constitution: Hans Kelsen and Carl Schmitt on the limits of constitutional law. Cambridge: Cambridge University Press, 2015. 
VITROLLES, Eugène François Auguste d'Arnauld, baron de. Du ministère dans le gouvernement représentatif (par un membre de la Chambre des Députés). Paris: Dentu, 1815.

WARESQUIEL, Emmanuel de. Un paradoxe politique: La Chambre « introuvable » et la naissance du parlementarisme français (octobre 1815 - avril 1816). Commentaire, v. 58, n. 2, p. 409-416, 1992. 